Reflexões sobre o ensino de metodologias ágeis na academia, na indústria e no governo

Alexandre Freire da Silva

\author{
DisSERTAÇÃo APRESENTADA \\ $\mathrm{AO}$ \\ Instituto de Matemática e Estatística \\ DA \\ Universidade de São Paulo \\ PARA \\ OBTENÇÃO DO TÍTULO \\ DE \\ Mestre em CiÊnCias
}

Área de Concentração: Ciência da Computação

Orientador: Prof. Dr. Fabio Kon 


\section{Reflexões sobre o ensino de metodologias ágeis na academia, na indústria e no governo}

Este exemplar corresponde à redação final da dissertação devidamente corrigida e defendida por Alexandre Freire da Silva e aprovada pela Comissão Julgadora.

Banca Examinadora:

- Prof. Dr. Fabio Kon (orientador) - IME-USP.

- Prof. Dr. Alan Mitchell Durham - IME-USP.

- Prof. Dr. Clóvis Torres Fernandes - ITA. 


\section{Agradecimentos}

Agradeço meu orientador pela paciência e compreensão ao longos destes últimos 3 anos pelos quais este trabalho se alongou. Agradeço todos meus mestres, minha família e meus amigos por tudo que me ensinaram. Agradeço aos meus livros, meus discos e meu cachorro pelo apoio incondicional. I also thank the outer space structures for something that will stay between me and them. Agradeço também a Kent Beck por uma única frase que me inspirou além de todas as outras:

"A única coisa que se sabe sobre um plano é que as coisas não sairão de acordo com ele." 


\section{Resumo}

As metodologias ágeis e em especial a Programação eXtrema (XP) surgem como um contraponto aos métodos tradicionais de desenvolvimento de software. Nos encontramos em um momento no qual considera-se aceitável encontrar defeitos em programas de computador, até mesmo naqueles sistemas pelos quais temos que pagar muito dinheiro. Melhorar o ensino de técnicas para que equipes possam colaborar no desenvolvimento de software de qualidade é essencial para que esta área do conhecimento alcance a maturidade que esperamos.

$\mathrm{O}$ ensino de XP é uma tarefa relativamente complexa pois exige que pessoas passem por uma mudança cultural, para aceitar seus valores, princípios e práticas. Diferentes organizações precisam adaptar a metodologia para que ela funcione bem em seu contexto local. Encontrar maneiras de facilitar o ensino e a adoção das práticas ágeis é fundamental para melhorar a qualidade do software desenvolvido no país.

Este trabalho pesquisa o ensino de XP em contextos acadêmicos, governamentais e industriais. Três estudos de caso foram conduzidos e analisados para sugerir padrões que podem auxiliar o ensino da metodologia por um educador em qualquer contexto.

Palavras-chave: Ensino, Metodologias Ágeis, Programação eXtrema, XP, Anti-Padrões, Padrões de Organização e Processo, Métodos de Desenvolvimento de Software, Engenharia de Software. 


\section{Abstract}

Agile methodologies, specially eXtreme Programming (XP), appear as a counterpoint to traditional software development methods. We live in a moment were it is considered acceptable to find bugs in computer programs, even those for which we pay a lot of money. It is essential to improve the way we teach techniques with which teams can collaborate on the development of quality software so that this area of knowledge reaches the maturity we wish.

Teaching XP is a relatively complex task because it implies that people must go through a cultural change to accept its values, principles, and practices. Different organizations need to adapt the methodology so that it will work well in their local context. Finding ways to facilitate teaching and adopting agile practices is fundamental to improve the quality of software being developed in the country.

This work researches the process of teaching XP in academic, governmental and industrial contexts. Three case studies were conducted and analyzed so that we could suggest patterns that can support educators teaching the methodology in any context.

Keywords: Teaching, Agile Methodologies, eXtreme Programming, XP, Anti-Patterns, Organizational and Process Patterns, Software Development Methods, Software Engineering. 


\section{Sumário}

Lista de Figuras $\quad$ xi

1 Introdução 1

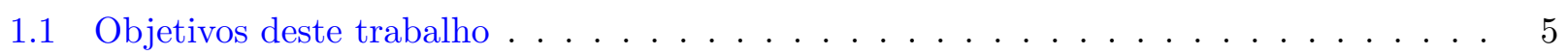

1.2 Não são objetivos deste trabalho $\ldots \ldots \ldots \ldots \ldots \ldots$

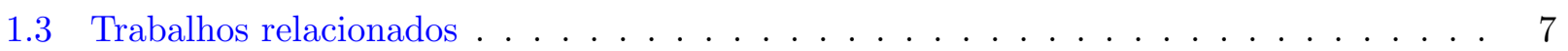

2 Uma reflexão sobre XP $\quad 9$

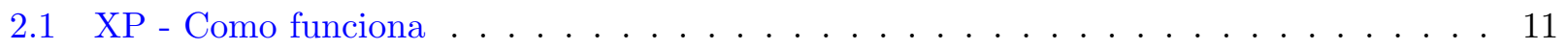

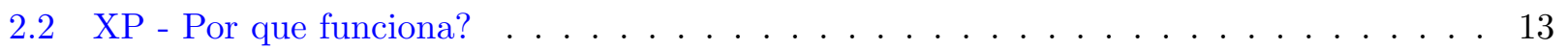

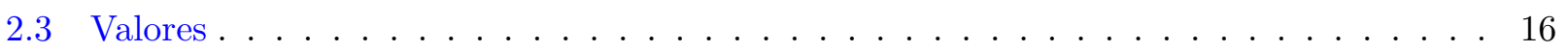

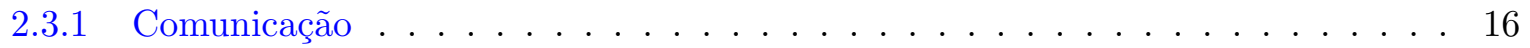

2.3 .2 Simplicidade . . . . . . . . . . . . . . . . 17

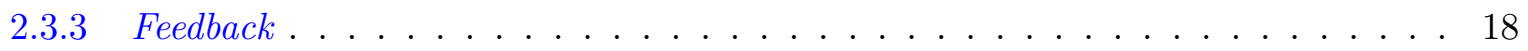

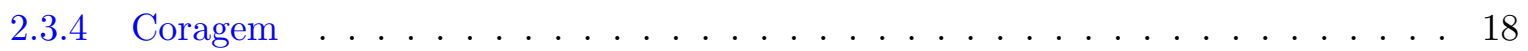

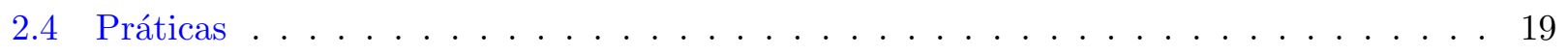

2.4 .1 Jogo do planejamento . . . . . . . . . . . . . . . . . . . . . . 19

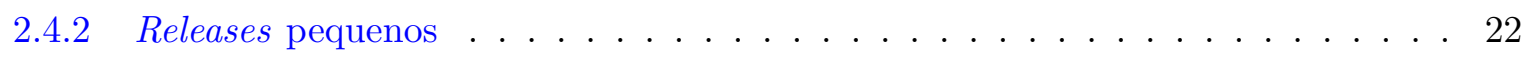

2.4 .3 Metáfora . . . . . . . . . . . . . . . . . . . . . 22

2.4 .4 Design simples . . . . . . . . . . . . . . . . . . . . 23

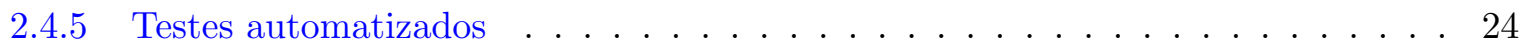

2.4 .6 Refatoração . . . . . . . . . . . . . . . . . . . . . . . . 24

2.4 .7 Programação pareada . . . . . . . . . . . . . . . . 25 


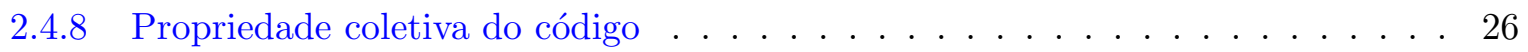

2.4 .9 Integração contínua . . . . . . . . . . . . . . . . . . 27

2.4 .10 Ritmo sustentável . . . . . . . . . . . . . . . . . . 28

2.4.11 Cliente sempre presente . . . . . . . . . . . . . . . . . 29

2.4 .12 Padrão de codificação . . . . . . . . . . . . . . . . . . . 29

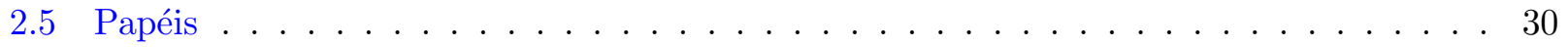

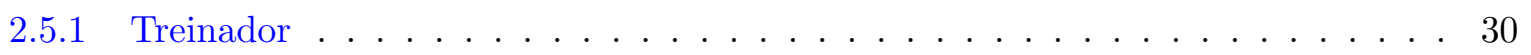

2.5 .2 Acompanhador . . . . . . . . . . . . . . . . . . 31

2.6 Adaptações e a adoção de novas práticas . . . . . . . . . . . . . . . . . . . . . 33

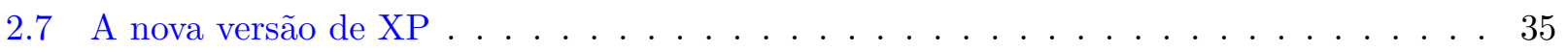

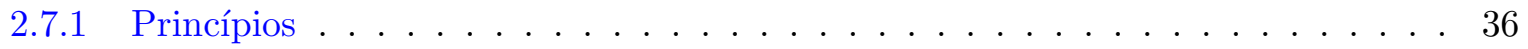

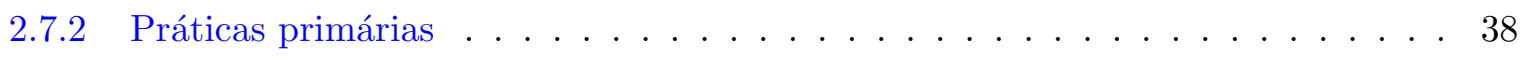

2.7 .3 Práticas corolário . . . . . . . . . . . . . . . . . . . 40

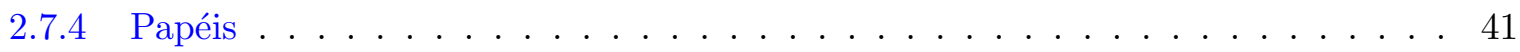

2.7 .5 Mudanças e evoluções . . . . . . . . . . . . . . . . . . . . . . . . 42

3 Experiências com o ensino de XP 44

3.1 Trabalhos relacionados na Academia . . . . . . . . . . . . . . . . . . 46

3.2 Laboratório de XP - 2001 a $2007 \ldots \ldots \ldots$. . . . . . . . . . . . 49

3.2 .1 Como funciona o Laboratório . . . . . . . . . . . . . . . . . . . . 51

3.2.2 Mico - Sistema para administração de carga didática - nossa primeira experiência 56

3.2.3 Marcador de Reuniões - grupo pequeno utiliza Smalltalk . . . . . . . . . . . . . 59

3.2.4 Colméia - Gerenciador de Biblioteca - evolução de um projeto ao longo dos anos 60

3.2.5 Cigarra - Distribuidor Multimídia - clientes externos em um grande projeto governamental . . . . . . . . . . . . . . . . . 6 60

3.3 Trabalhos relacionados na Indústria $\ldots \ldots \ldots$. . . . . . . . . . . 63

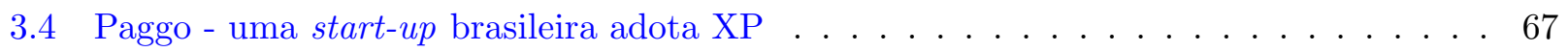

3.5 Trabalhos relacionados no Governo . . . . . . . . . . . . . . . . . . 72

3.6 Ministério da Cultura - O projeto Cultura Digital . . . . . . . . . . . . . . 74 
3.7 Workshops, cursos, jogos, eventos e a comunidade . . . . . . . . . . . . 81

4 Análise e reflexão sobre o ensino de XP $\quad 85$

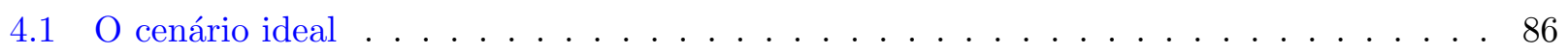

4.2 Etapa inicial - Começando o processo de transição . . . . . . . . . . . . . . . . 88

4.2.1 Padrões para convencer sua organização a praticar XP . . . . . . . . . . . 89

4.2 .2 Padrões para lidar com a resistência inicial . . . . . . . . . . . . . . . . . 91

4.2.3 Padrões para escolher um treinador e envolver-se realmente com o cliente . . 92

4.2 .4 Padrões para montar uma equipe . . . . . . . . . . . . . . . 94

4.2.5 Padrões para estruturar o espaço de trabalho . . . . . . . . . . . . 96

4.2.6 Padrões para o planejamento da primeira experiência prática $\ldots$. . . . . . . 97

4.3 Aprendizado através da prática - Amadurecimento da metodogia . . . . . . . . . . 100

4.3 .1 Padrões de treinamento . . . . . . . . . . . . . . . . . . 101

4.3 .2 Padrões de planejamento contínuo . . . . . . . . . . . . . . . 103

4.3 .3 Padrões de design . . . . . . . . . . . . . . . . . . 106

4.3 .4 Padrões para aplicar no dia-a-dia . . . . . . . . . . . . . 107

4.4 Etapa final - A equipe desenvolve sua própria metodologia . . . . . . . . . . . . . . . 110

4.4 .1 Observações Póstumas . . . . . . . . . . . . . . . . . . . . . . . 111

4.5 Práticas ágeis para trabalhar colaborativamente . . . . . . . . . . . . . 113

5 Conclusões $\quad 117$

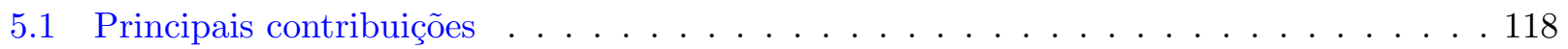

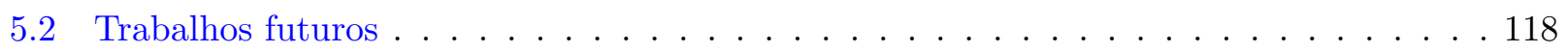

5.3 Artigos publicados durante o Mestrado . . . . . . . . . . . . . . . . . . . 119

$\begin{array}{ll}\text { Referências Bibliográficas } & 121\end{array}$

Índice Remissivo 134 


\section{Lista de Figuras}

2.1 Diagrama explicitando um grafo de relações de apoio mútuo entre as práticas (BECK,

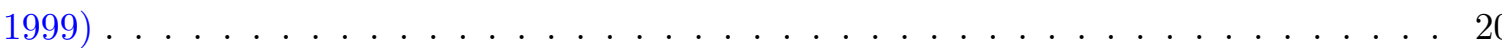

2.2 Cartaz com representação de métrica que ilustra o andamento do projeto (cada coluna é uma iteração). Histórias implementadas estão em verde, mudanças em histórias em amarelo e correção de defeitos em vermelho, tudo isso realizado em cada iteração.

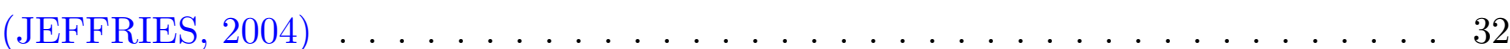

2.3 A evolução das práticas de XP da primeira para segunda versão . . . . . . . . . . . . . 43

3.1 O espaço do laboratório de Programação eXtrema . . . . . . . . . . . . . . . . 51

3.2 Uma equipe ocupa suas estações de programação pareada no laboratório . . . . . . . . 52

3.3 Um par desenvolvendo seu sistema engajados na resolução de uma tarefa . . . . . . . 53

3.4 O quadro branco de uma equipe sendo utilizado como radiador de informações . . . . 54

3.5 Radiadores de informações colados na parede: um calendário Niko-Niko; a evolução do número de linhas, classes e testes nos diferentes módulos do sistema; um diagrama UML e o resultado de uma retrospectiva . . . . . . . . . . . . . . . . . . . 54

3.6 Dois professores que também atuam como clientes refletem sobre os projetos em andamento durante o almoço extremo. . . . . . . . . . . . . . . . . . . 55

3.7 Evolução de número de testes de uma equipe detalhada numa tabela pelo seu acom-

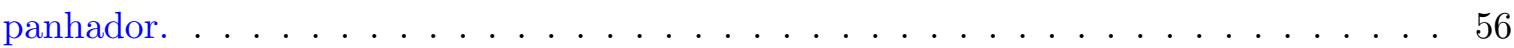

3.8 Histórias de uma equipe on-line no XPlanner. . . . . . . . . . . . . . . . . . 57

3.9 Enfermeiras clientes do Borboleta acompanham a apresentação de um release. . . . . . 58

3.10 O treinador da equipe Cigarra atuando . . . . . . . . . . . . . . . . 61

3.11 Reunião de apresentação do primeiro release da equipe Cigarra . . . . . . . . . . . . . 62

3.12 Dois pares trabalhando no espaço aberto e informativo da Paggo . . . . . . . . . . . 68

3.13 Acompanhadora atualizando medidas nos radiadores de informação da Paggo . . . . 69 
3.14 Radiador de informação com acompanhamento de um dos primeiros releases de sistemas da Paggo compara o tempo estimado e o tempo real gasto em cada história

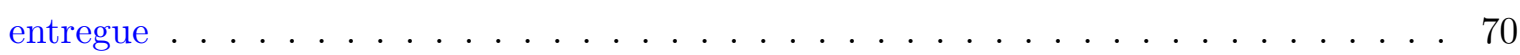

3.15 Quadro de histórias para acompanhar o andamento de um release na Paggo . . . . . . 71

3.16 Radiador de informação mostrando evolução da base de código de um dos sistemas da

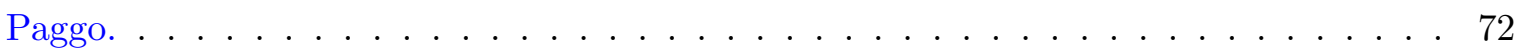

3.17 Cliente proxy pareando com um desenvolvedor na primeira semana extrema da Cultura

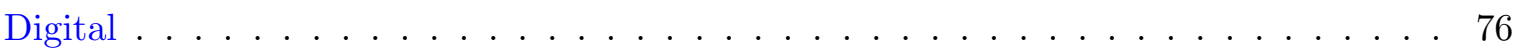

3.18 Cliente proxy (em pé) durante jogo do planejamento na Cultura Digital . . . . . . . 78

3.19 Quadro de Histórias de iterações dos 3 sistemas desenvolvidos no espaço aberto da Cultura Digital . . . . . . . . . . . . . . . . . . . . . . 79

3.20 Programação pareada no novo espaço da Cultura Digital . . . . . . . . . . . . . . . . . 80

3.21 O Ministro da Cultura Gilberto Gil fala sobre Cultura Digital em uma palestra em Londres. . . . . . . . . . . . . . . . . . . . . . . 81

3.22 Jogadores em um Jogo de XP trabalham para resolver uma história. . . . . . . . . . . 83

3.23 Um par se concentra durante um kata do Coding Dojo. . . . . . . . . . . . . . . . . 84

4.1 O padrão Mapa Mental pode ser usado para entender melhor a metodologia. Neste mapa mental criado em grupo de estudos da conferência XP 2007 visualizamos as práticas relacionadas ao planejamento de um projeto . . . . . . . . . . . . . . 90

4.2 O anti-padrão Personalidades Múltiplas pode ser resolvido com um chapéu . . . 94

4.3 Um mural mostra o planejamento ágil de uma oficina de conhecimentos livres. Participantes podiam propor mudanças no cronograma e até mesmo novas atividades durante a oficina . . . . . . . . . . . . . . . . . . . . . 115

4.4 Retrospectivas são úteis para qualquer equipe que trabalha de maneira colaborativa visualizar o que foi feito em um projeto e sugerir ações concretas de melhoria . . . . . 116 


\section{Capítulo 1}

\section{Introdução}

Atualmente, não há dúvidas de que a indústria de software se estabeleceu como uma das mais importantes. Computadores, cada vez menores e mais rápidos, se espalham ubiquamente pelo mundo, presentes em grande parte das ferramentas usadas pelos seres humanos, de geladeiras a telefones celulares, de carros a casas. Empresas, sejam elas micro, pequenas, médias, grandes ou gigantes do mercado, investem em computadores e programas para conseguir sobreviver na era da Tecnologia da Informação. O mercado do desenvolvimento é um dos únicos no qual a demanda por trabalhadores continua maior do que a oferta. Num mundo onde o segundo homem mais rico do planeta alcançou esta posição vendendo software, não há mais como questionar a importância desta prática produtiva. Constatamos que melhorar o ensino e divulgação de métodos de desenvolvimento de software é importante tanto para a própria indústria, quanto para a sociedade como um todo. Para tornar o Brasil um país de destaque no mercado global de software, precisamos refletir sobre a produção de software, como se dá esse processo hoje e como podemos melhorá-lo.

É natural pensar que uma tecnologia tão recente quanto o computador ainda não tenha encontrado maturidade suficiente para podermos dizer que sabemos tudo sobre a natureza da produção de programas. A disciplina de Engenharia de Software surgiu há apenas 38 anos, desde então diversos estudos são realizados para tentar tornar a criação de software mais eficiente e menos propensa a erros. Mesmo assim, não temos experiência suficiente nesta arte se comparada ao conhecimento adquirido em outras disciplinas mais maduras. A Engenharia Civil, por exemplo, tem suas raízes nas primeiras civilizações humanas. Aprendendo com a experiência dos romanos, hoje em dia construímos pontes muito mais baratas e eficientes.

Por mais esforço e dinheiro que se aplique nesta indústria, grande parte dos projetos de software hoje em dia fracassa. O software produzido ou é defeituoso, ou éinadequado aos desejos do cliente, ou é entregue fora do prazo, ou está acima dos custos esperados. O último CHAOS Report [Sta03], estudo envolvendo milhares de projetos na área de Tecnologia de Informação, revela que $51 \%$ deles se encontram em situação de risco, $15 \%$ fracassaram e somente um terço, $34 \%$, foram bem sucedidos. No total, $43 \%$ dos projetos custaram acima do esperado e $82 \%$ foram entregues fora do prazo. Somente $52 \%$ das funcionalidades desejadas foram implementadas no produto entregue. 
Uma das principais causas de tantos fracassos é, obviamente, a falta de qualificação dos profissionais, como apontam alguns estudos [ASA79,PE85,vG91, Cro02]. Grande parte da força de trabalho, especialmente em países em desenvolvimento como o Brasil, é composta por pessoas com pouca instrução formal, ou auto-didatas que através de documentação e exemplos disponíveis em livros e na Internet conseguiram dominar o necessário da técnica para serem aceitos no mercado de trabalho. Mercado este que, infelizmente, além de não incentivar e apoiar o crescimento de seus funcionários, adota linguagens de programação e métodos movido mais pela força do marketing das empresas que as desenvolveram e conseqüente disponibilidade de desenvolvedores que as conhecem, do que seus méritos técnicos.

Programar é o ato de codificar, em alguma linguagem, instruções que serão processadas em um computador; é uma atividade que vem sendo exercida por um número cada vez maior de pessoas. Com a disseminação dos computadores, programar deixou de ser uma atividade exclusiva de engenheiros ou cientistas da computação. Existem muitas ferramentas e técnicas que pretendem facilitar a vida dos programadores. Os programas livres e de código aberto oferecem a todos excelentes ferramentas, arcabouços e fontes de inspiração e aprendizado. Comunidades internacionais se organizam para trocar informações e ajudar novos desenvolvedores. Empresas investem em novos processos e metodologias, cujas opções variam de acordo com o tamanho do projeto, tamanho da equipe de desenvolvedores e até mesmo a exigência de algum tipo de certificação.

A falta de educação de qualidade acessível aos programadores é uma das principais causas de falhas em software. Neste trabalho, iremos abordar o ensino de metodologias ágeis, suas práticas e processos. Esta é uma contribuição valiosa para a comunidade, pois investindo na educação dos desenvolvedores podemos, em conseqüência, melhorar a qualidade do seu trabalho.

Poucos dos métodos de desenvolvimento concentram seus esforços nas pessoas, nos programadores. Usando a metáfora comum de Engenharia de Software, muitos tratam o software como qualquer outro bem industrial e o programador como um operário, mais uma peça da linha de produção. Para produzir software, inspiram-se em técnicas nascidas na revolução industrial. Toffler [Tof01] escreve o seguinte sobre essa revolução:

"Um trabalhador único tradicional, efetuando todas as operações necessárias sozinho, podia produzir apenas um punhado de alfinetes por dia, não mais de 20 e talvez nem um. Em contraste, numa manufatura, na qual se exigiam 18 operações diferentes efetuadas por dez trabalhadores especializados, cada um efetuando apenas uma ou algumas fases, juntos conseguiam produzir mais de 48 mil alfinetes por dia, mais de quatro mil e oitocentos por trabalhador."

(TOFFLER, 2001, p.62).

Ao analisar esses métodos, constata-se que seus proponentes confiam que dividir equipes e respon- 
sabilizar pequenos grupos por tarefas especializadas é o caminho para criar uma fábrica de software eficiente. Como o software não é um bem material, ao encaminhá-lo de uma posição a outra na linha de montagem, estes métodos ditam que vários artefatos e documentação detalhada devem acompanhar o código. Um longo período de planejamento é necessário para especificar cuidadosamente o objetivo do software e depois criar uma arquitetura que será dividida em pedaços que poderão ser então codificados, integrados e, finalmente, testados e enviados ao cliente.

Os proponentes desses métodos erram ao acreditar que o desenvolvimento de software, essencialmente um trabalho criativo, possa ser otimizado nesse modelo desenvolvido para acelerar a produção de bens materiais. "Engenharia" é uma metáfora que foi empregada ao desenvolvimento de software de maneira equivocada. Diversos autores discutem a diferença entre os trabalhadores manuais e os trabalhadores criativos, ou trabalhadores do conhecimento. Domenico de Masi [dM00] exemplifica:

\begin{abstract}
"Se sou um publicitário e estou tentando criar um slogan, quando saio do escritório e volto para casa, levo o trabalho comigo: na minha cabeça. A minha cabeça não pára de pensar e às vezes acontece que posso achar a solução para o slogan em plena noite, ou debaixo do chuveiro, ou ainda naquele estado intermediário entre o sono e o despertar"
\end{abstract}

(MASI, 2000, p.205).

Beck, na segunda edição de seu livro sobre Programação eXtrema [BA04], cita como base filosófica da metodologia algumas falhas em se aplicar a metáfora da engenharia, herança da revolução industrial, ao desenvolvimento de software:

"Enquanto o Taylorismo tem alguns efeitos positivos, também tem sérias deficiências. Essas limitações tem origem em três preconceitos:

1. As coisas normalmente acontecem como planejado.

2. Micro-otimização leva à macro-otimização.

3. Pessoas podem ser substituídas e precisam receber ordens para trabalhar."

(BECK, 2004, p.132).

Beck discute a importância do Taylorismo, movimento inspirado por Frederick Taylor [Tay47] que impulsionou a revolução industrial, relativa ao desenvolvimento de software. Ele aponta a existência de duas mudanças sociais implícitas nessa revolução. A primeira é a separação entre planejamento e execução. Trabalhadores devem executar a tarefa delegada fielmente, da maneira pré-estipulada e no tempo determinado previamente. A segunda é a criação de um Departamento de Qualidade 
separado, o que implica que qualidade não é responsabilidade de todos. Beck conclui o seguinte:

“... estruturas sociais Tayloristas impedem o fluxo de comunicação e feedback vitais para criação de software funcional, flexível e barato, em um mundo que está em constante mudança."

(BECK, 2004, p.133)

Fowler [Fow00] também critica a separação social entre engenheiros e arquitetos e programadores:

"Na construção civil há mais clareza na separação de habilidades entre aqueles que planejam e desenham e os que constroem, mas esse não é o caso no desenvolvimento de software. Qualquer programador trabalhando em um ambiente de design complexo precisa ser habilidoso o suficiente para questionar o design do arquiteto, especialmente quando este tem menos conhecimento sobre as realidades do dia-a-dia do desenvolvimento da plataforma."

(FOWLER, 2000, p.1)

Até mesmo no chão de fábrica provou-se que questionar essas premissas leva ao aumento da produtividade. O Sistema de Produção da Toyota [Mon98] inovou e quebrou recordes produtivos ao eliminar o departamento de qualidade, tornando todos trabalhadores responsáveis por ela.

Mesmo assim, muitas empresas no ramo de desenvolvimento de software insistem em usar técnicas oriundas da revolução industrial ou de áreas como a construção civil. Uma delas, bastante comum, é a de associar bônus remunerativos ao aumento da produção, para incentivar seus empregados. Existem estudos econômicos [FG02, FL04, FJ01, FOG97] que comprovam que este tipo de contrato de incentivo, no âmbito da produção criativa, não funciona, reduzindo a produtividade e a cooperação voluntária. Yochai Benkler [Ben02] aponta que a construção de boas relações sociais e o incentivo ao compartilhamento de conhecimento tem efeitos positivos no aumento da produtividade e na cooperação.

Foi pensando nisso, na construção de um ambiente de trabalho melhor e mais produtivo, que surgiram as metodologias ágeis de desenvolvimento de software. No começo de 2001, diversos agentes subjacentes a métodos novos se reuniram e escreveram o Manifesto Ágil. Entre os métodos representados estavam: Adaptive Software Development, Programação eXtrema (eXtreme Programming XP), Scrum, Crystal, Feature Driven Development (FDD), Dynamic System Development Method (DSDM), Lean Software Development e Pragmatic Programming. No manifesto, todos concordaram em alguns valores comuns: as metodologias ágeis concentram-se nas pessoas envolvidas na produção, assumem que planejamentos a longo prazo são sempre falhos e que o importante é ser ágil para poder lidar com mudanças entregando, continuamente, software funcional. Em comparação com métodos 
tradicionais o conjunto de técnicas e práticas dos métodos ágeis é menor e mais simples, fazendo com que a sua adoção seja relativamente fácil para organizações interessadas. Além disso, o acompanhamento das atividades deixa de ser subjetivo, tornando mais fácil prestar conta do progresso em um projeto.

O manifesto ágil [Al101] diz o seguinte:

"Estamos trazendo à tona novas e melhores maneiras de desenvolver software desenvolvendoo e ajudando outros a desenvolvê-lo. Através deste trabalho viemos a valorizar:

- Indivíduos e interações ao invés de processos e ferramentas

- Software funcional ao invés de documentação completa e detalhada

- Colaboração com o cliente ao invés de negociações de contrato

- Adaptação a mudanças ao invés de seguir planos

isto é, enquanto os itens à direita têm valor, nós valorizamos mais os itens à esquerda."

(Kent Beck, Mike Beedle, Arie van Bennekum, Alistair Cockburn, Ward Cunningham, Martin Fowler, James Grenning, Jim Highsmith, Andrew Hunt, Ron Jeffries, Jon Kern, Brian Marick, Robert C. Martin, Steve Mellor, Ken Schwaber, Jeff Sutherland, Dave

Thomas, 2001)

Uma das primeiras metodologias ágeis propostas foi a Programação eXtrema (XP - eXtreme Programming). XP inova com um conjunto pequeno de práticas que podem ser adotadas rápida e efetivamente por organizações de pequeno, médio e grande porte, aumentando a produtividade da organização e a qualidade do software produzido.

XP se concentra nas atividades dos programadores e a maioria das práticas são voltadas para eles. A Programação eXtrema também dá muita atenção ao escopo do software a ser produzido, prometendo entregar exatamente o que o cliente precisa no menor tempo e com o menor custo possível.

Nos poucos anos que o ato de produzir software teve para amadurecer, pode-se dizer que as metodologias ágeis inovam ao indicar um caminho mais natural para o trabalhador criativo, proporcionando melhores condições para que a indústria possa produzir software de qualidade e para que o criador possa exercer seu trabalho de maneira mais humana.

\section{$1.1 \quad$ Objetivos deste trabalho}

Esta dissertação tem como objetivo analisar experiências de ensino e implantação de XP e práticas ágeis tanto na universidade quanto em empresas privadas e projetos governamentais. Iremos refletir sobre as práticas propostas pela metodologia e maneiras de ensinar grupos de estudantes e programadores a adotá-las no seu dia-a-dia. Mudar a cultura de um grupo nem sempre é tarefa simples, 
ainda mais quando propomos práticas ágeis, que geram resistência em grande parte das pessoas. O ensino de metodologias ágeis, em especial de XP, não é algo trivial. Iremos mostrar como valores e práticas de outros métodos ágeis e a própria evolução da Programação eXtrema ao longo dos anos nos ajudam a observar padrões que podem facilitar esta tarefa.

Iremos começar com uma descrição reflexiva da metodologia, apresentando em mais detalhes a sua primeira versão [Bec99], discutindo e analisando brevemente cada um dos valores, das práticas e dos papéis exercidos pelos membros de uma equipe XP. Nessa discussão pretendemos refletir sobre os detalhes peculiares de cada prática e seus efeitos, assim como a relação entre diferentes práticas, valores e papéis. Iremos também considerar a evolução da metodologia para sua segunda versão [BA04], um refinamento dos valores, práticas, princípios e papéis realizado por Beck após cinco anos de amadurecimento e pesquisa metodológica.

Em seguida, pretendemos fazer um relato dos casos que estudamos neste trabalho. Apresentaremos uma síntese das diversas experiências observadas, começando com um apanhado de evidências na literatura e depois descrevendo com maiores detalhes um estudo de caso nosso em cada um dos diferentes contextos abordados. Em primeiro lugar, iremos apresentar o resultado de cinco anos de experiência no ensino de grupos de alunos universitários, de graduação e pós-graduação, cada qual trabalhando em um projeto específico dentro do escopo de uma disciplina optativa com duração de um semestre, o Laboratório de Programação eXtrema do IME/USP [GKSY04]. Em segundo lugar, discorreremos sobre a experiência de implantar XP em uma organização privada, a Paggo, na qual todos os funcionários aprenderam as técnicas e valores de XP e passaram a adotar Programação eXtrema como sua metodologia padrão. Em terceiro lugar, iremos refletir sobre a experiência de implantar XP em alguns projetos de cunho governamental no Ministério da Cultura. Finalmente, iremos falar sobre a experiência de participar de eventos da comunidade, organizar palestras e jogos, ministrar cursos de curta duração e oferecer pequenas consultorias com o intuito de divulgar métodos ágeis.

Depois iremos apresentar uma análise e reflexão sobre a experiência do ensino desta metodologia nesses contextos diferenciados. Pretendemos resumir questões relacionadas a cada uma das práticas em cada caso, além de apresentar novas práticas e práticas de outros métodos experimentadas, as razões por fazê-lo e os efeitos observados. Vamos apresentar intervenções nos diferentes papéis que fazem parte da metodologia e discutir o mérito e a eficácia de tais intervenções nos diferentes casos. Iremos ainda discutir as maiores dificuldades e problemas encontrados, apresentando sugestões a partir de nossa análise qualitativa realizada que evidência as diferenças entre os contextos.

Durante essa exposição, iremos refletir sobre o ensino desta metodologia e das práticas ágeis, organizando práticas e idéias como linguagens de padrões que podem ser adotados por outros, além de anti-padrões que devem ser evitados. Iremos apresentar estas linguagens na ordem em que elas poderão ser adotadas para melhorar o ensino de metodologias ágeis em uma organização, da etapa inicial de convencimento à etapa final de amadurecimento, possivelmente ajudando futuros processos 
de implantação de XP em ambientes similares aos estudados. Iremos também discutir a adoção de práticas ágeis em outras áreas de uma organização, não necessariamente técnicas, refletindo sobre duas experiências do tipo.

\subsection{Não são objetivos deste trabalho}

Não é objetivo deste trabalho introduzir XP em detalhes ao leigo ou apresentar os vários métodos ágeis. Para isso recomendamos a leitura dos livros introdutórios sobre os temas. [Bec99] e [BA04] introduzem XP. Os outros métodos ágeis são introduzidos em: Adaptive Software Development [III99], Scrum [SB01], Crystal [Coc04], Feature Driven Development (FDD) [PF02], Dynamic System Development Method (DSDM) [Sta97], Lean Software Development [PP03] e Pragmatic Programming [HT00]

Além disso, não iremos descrever experimentos científicos controlados ou pesquisas para avaliar quantitativamente a eficácia de XP e outros métodos ágeis, assim como não fazemos um trabalho exaustivo nem possuímos amostras suficientes para generalizar soluções em qualquer contexto acadêmico, industrial ou governamental. Outros estudos foram realizados de forma a coletar dados de experiências com XP para avaliar o sucesso de projetos e a eficácia de práticas, analisando dados qualitativos e quantitativos para validar os métodos ágeis em diferentes contextos. Interessados nessas análises podem ler [Ver06, Tes03, RS02, Rei02, SSP01, Mis06, SPA+ 06, SA04, Lay04, KVRR03, LWC04b, WKLA04, SGK07, SBB+ 07].

No mais, não pretendemos descrever software desenvolvido com XP. Interessados nesse tema podem ler nossos estudos que concentram sua análise nos programas criados [ $\mathrm{FGF}^{+}$04,FS04,FGK05].

O fator psicológico de satisfação no trabalho é um aspecto interessante que inicialmente pensamos em abordar mas que foi retirado posteriormente do escopo por limitações de tempo, interessados podem ler estudos que levam em conta o uso de métodos ágeis do ponto de vista psicológico e de motivação no trabalho [Cho05, MMM04, Asp04, MM06].

\subsection{Trabalhos relacionados}

Apesar de toda atenção que os métodos ágeis vêm recebendo atualmente, eles são relativamente recentes e não chegaram a completar nem uma década de existência.

A série de livros introdutórios de XP, apelidada de XP Series, que fala em detalhes sobre a metodologia [Bec99,BA04,LC03a,DW03,KA02,Wak02,RJ01,KB01], além do livro sobre metodologias ágeis de Cockburn [Coc02], são a base teórica de onde obtivemos grande parte do conhecimento necessário para ensinar as práticas e técnicas das metodologias ágeis. Destes livros, apenas o clássico de Kent Beck [Bec99] foi traduzido para o português e existe apenas um livro sobre a metodologia XP [Tel04] de autores brasileiros.

As referências estão presentes ao longo da dissertação, mas julgamos interessante apresentá-las rapidamente, separadas em tópicos nesta seção. 
Interessados em casos de sucesso de uso de XP podem ler duas dissertações sobre experiências brasileiras [Te105, Sat07]. Muitos artigos também relatam casos de sucesso de adoção da metodologia [Pel00, Lit00, SIC01, DMM02, FH03, Bos03b, How03, LWC04a, Ant04, Jac04, FKT05, BK07].

Diversos trabalhos foram efetuados sobre as práticas de XP isoladamente. Interessados podem ler sobre programação pareada, prática anterior a XP, muito aprofundada no trabalho de Laurie Williams [Wil00, WK00, WKCJ00, CW00, WK02, WWY 02]. Outros autores também abordam a programação pareada: [Tom02a, LC03b, $\mathrm{NWW}^{+}$03, HA05, LC06]. Por ser de muita importância na metodologia, o papel do cliente também já foi bastante estudado [Gri01,FNKW02, WBA02, MNB03, KA04,Mar04,MN04] e [Mar07]. Testes automatizados também tem sua própria literatura, a começar pelo trabalho sobre desenvolvimento dirigido por testes de Kent Beck [BG98, Bec02a], passando por avaliações e casos de outros autores [Mug03, MP03, LC04, GW04], até literatura específica sobre testes de aceitação [CHW01, ABS03] e testes de interfaces gráficas [Mem01, Mem02]. Histórias já foram estudadas [And01, Mes04] e existem trabalhos que aprofundam-se sobre aprendizado de estimativas [Bos03a]. Em [Rog04] discute-se como escalar a prática de integração contínua para muitos desenvolvedores. Refatoração também é anterior a XP e tem pesquisa própria: [Fow99,AS06] e [MS99].

Ensinar XP, o tópico principal do nosso trabalho, é também um tópico bem discutido na academia. Alguns artigos interessantes abordam esse desafio de diferentes pontos de vista [ADW01, Wil01, HGM01, MT01,Lap02, Tom02b, SW02, HBM03b,BPBLS03, SJ03, SAHG03, NA03, MMRT03,HBM03a, HD03, Dub03, MFR ${ }^{+}$04, Mül04, MLSM04, HBC+ 04, GKSY04, NMMB04, DH04, HBM05].

São raros trabalhos relatando casos de fracasso de XP; estes normalmente estão ligados a um processo falho de adoção do método ou a adoção parcial do método [Ave04]. Como relata [JST01]: o método requer investimento no aprendizado prático, provocando críticas de pessoas que não estão dispostas a mudar os seus valores, comportamentos e cultura.

Trabalhos sobre falhas, fracassos e críticas existem: [Bos02, CS05, Kee02, SJ05]. Um pouco antes de Beck publicar a sua reformulação da metodologia, dois livros [McB03, SR03] foram publicados com críticas e propostas de mudanças em alguns de seus aspectos. 


\section{Capítulo 2}

\section{Uma reflexão sobre XP}

Programação eXtrema surgiu na indústria em 1997, quando Kent Beck e um grupo de oito consultores das comunidades de padrões e orientação a objetos foram chamados para salvar um projeto de software da Chrysler [Bec99]. Era o sistema de folha de pagamento, estava atrasado e já tinha custado muito mais do que deveria. Durante um ano, uma equipe de vinte e seis pessoas não conseguiu entregar uma versão funcional do software. No ano seguinte, Kent Beck e sua equipe conseguiram. Eles experimentaram uma metodologia diferente levando ao extremo linguagens de padrões organizacionais e de processo que foram reconhecidos pela comunidade ao longo dos anos. Assim nasceu o primeiro caso de sucesso de XP. Em 1999, Beck escreveu seu primeiro livro sobre a metodologia, optando por usar a palavra extreme para chamar a atenção dos programadores ao fato de que o novo método tentava aplicar muitas das práticas reconhecidamente boas da programação e levá-las ao extremo. Por exemplo, se revisão de código é uma boa prática, em Programação eXtrema todo o código escrito será revisado enquanto está sendo criado - é a prática extrema de programação pareada, ou programação em pares. Outro exemplo, se testar o código é uma boa prática, iremos testar todo o código antes mesmo dele ser escrito - é a prática extrema de testes automatizados. A marca se tornou popular rapidamente e hoje em dia é uma metodologia reconhecida tanto na indústria quanto na academia. A segunda edição do livro de Beck [BA04] é uma evolução completa (até as práticas foram repensadas) e foi escrita com uma linguagem mais positiva e inclusiva em 2004, levando em consideração cinco anos de experiência da comunidade ágil e as críticas recebidas por causa da linguagem mais incisiva do primeiro livro.

O leitor deve ter percebido que até agora utilizamos tanto a palavra "método" quanto "metodologia" para nos referirmos à Programação eXtrema. Cabe um esclarecimento sobre a terminologia adotada. Ao pesquisar a palavra "metodologia" em dicionários, vemos que ela é definida de maneiras distintas. Uma maneira é "a arte de dirigir o espírito na investigação da verdade". Bela definição, porém longe do uso comum [dLPA]. Em outra definição vemos um "corpo de regras e diligências estabelecidas para realizar uma pesquisa", ou seja, como no uso coloquial comum, metodologia é sinônimo de "método", mas pode ser ainda "parte de uma ciência que estuda os métodos aos quais ela própria recorre" [dLP]. Neste trabalho pretendemos elaborar uma reflexão sobre o ensino de 
métodos ágeis. Ao fazê-lo iremos eventualmente classificar estes métodos, e XP com mais frequência, como metodologias, para ressaltar o estudo do próprio método como prática importante desta ciência. Ou seja, XP, como uma metodologia, define procedimentos de ensino da arte de programar software de qualidade coletivamente e, ao mesmo tempo, propõe o estudo científico dos próprios métodos adotados, podendo adaptá-los e evoluí-los de acordo com o contexto local.

XP nasceu como fruto das experiências e descobertas das comunidades de Smalltalk e padrões de projeto orientado a objetos. Após estudar os próprios métodos, desenvolvedores que utilizavam orientação a objetos generalizaram padrões de projeto [GHJV95]. Um padrão é uma solução reconhecida para um problema comum e recorrente. Uma linguagem de padrões é uma receita de maneiras possíveis de usar padrões e anti-padrões em combinação [AIS $\left.{ }^{+} 77\right]$. Um anti-padrão é uma solução aparentemente boa comumente aplicada para resolver um problema, mas que de fato cria um problema ainda maior [BMMIM98]. Anti-padrões propõe uma solução refatorada para fugir do problema. XP pode ser entendida como uma metodologia que propõe e estuda um conjunto de linguagens de padrões e anti-padrões de organização e processo já amplamente reconhecido [Amb98, Amb99, CCH96, CH04, RM05, BT00, KH04, FKG07]. Nada mais natural então que esta metodologia tenha sido criada e desenvolvida nesta comunidade.

Cockburn [Coc02] define uma metodologia como "as convenções com as quais um grupo concorda" e detalha os elementos que a compõem:

- Equipes de pessoas que entram em acordo sobre um conjunto de valores e princípios.

- Pessoas ocupando diferentes papéis na equipe, demandando habilidades e personalidades diferentes.

- Atividades realizadas no dia-a-dia da equipe, empregando diferentes técnicas, podendo gerar artefatos ou não.

- Um processo que diz como essas diferentes atividades interagem no tempo, quais são os eventos que marcam progresso e quais são as convenções seguidas pela equipe.

- A avaliação da qualidade dos produtos gerados e das atividades realizadas pela equipe.

Os padrões organizacionais e de processo são aplicados neste contexto e se dividem em linguagens que cobrem os diferentes aspectos da produção de software. Os padrões de processo descrevem abordagens de sucesso comprovadas pela comunidade, além de uma série de atividades que podem ocorrer ao desenvolver software. Os padrões organizacionais descrevem como criar e adaptar processos junto às organizações, como funcionam estes processos, como os diferentes papéis da equipe se relacionam, quais atividades são realizadas no trabalho e quais são os artefatos produzidos. Um estudo recente [dCFPSB05] mostra que vários destes padrões são reconhecidos nas metodologias ágeis.

A seguir, iremos conhecer os padrões que fazem parte de XP e observar como a linguagem de padrões subjacente à metodologia evoluiu ao mesmo tempo em que o estudo de seus próprios métodos 
continuou ao longo de cinco anos. Primeiro iremos apresentar o funcionamento da metodologia de acordo com a sua primeira versão e depois explicitar as razões que justificam a eficácia desta de acordo com a segunda versão do livro de Beck. Então, iremos entrar em detalhes sobre os valores, práticas e papéis da primeira versão. Ao apresentar cada prática iremos refletir sobre o relacionamento entre as práticas. Vamos também sugerir a adoção de outras práticas ágeis e a criação de práticas personalizadas. Finalmente iremos comentar as mudanças na segunda versão de XP, seus novos valores, princípios, práticas e papéis.

\subsection{XP - Como funciona}

$\mathrm{XP}$ é indicado para equipes pequenas e médias, que desenvolvem software baseado em requisitos não totalmente definidos e que se modificam rapidamente, por clientes com projetos que não envolvem risco à vida humana e cuja complexidade não seja alta. Na primeira versão de seu livro Beck define XP da seguinte forma:

"Programação eXtrema (XP) é uma metodologia leve para times pequenos e médios desenvolvendo software com requisitos vagos ou que mudam rapidamente."

(BECK, 1999, p.1)

A metodologia é leve, pois os processos definidos minimizam esforços burocráticos, e pequena, contendo apenas doze práticas e quatro papéis. Por isso, pode ser posta em prática em um período curto de tempo, sem grandes custos às empresas. É uma metodologia heurística e tolerante a adaptações, que faz com que a instituição aprenda com o passado e adapte a metodologia ao seu contexto. Algumas práticas requerem muita disciplina. Muitas práticas são interdependentes, completando-se e apoiando-se. Por isto, podem existir riscos na adoção de somente uma parte do conjunto de práticas. Por ter sido criada por programadores, a maioria das práticas focaliza sua atenção neles e no ato de programar.

Em XP, a equipe valoriza a comunicação entre as pessoas, a simplicidade do software e do próprio processo, o feedback constante e contínuo e a coragem.

Os valores se concretizam em alguns princípios básicos, evidenciados nas práticas da metodologia. O primeiro princípio é velocidade do feedback, o tempo entre uma ação e o seu devido retorno deve ser o mais curto possível, para assim melhorar o processo de aprendizado. Supor simplicidade implica que ao se deparar com um problema, as pessoas devem supor que ele é fácil de ser resolvido e procurar uma solução simples. Mudança incremental tenta evitar grandes mudanças repentinas, pois elas simplesmente não funcionam, priorizando pequenas mudanças que devem ser realizadas de forma contínua. Para resolver o problema mais importante que existe no momento, acolher mudanças é uma boa estratégia, desde que novas mudanças ainda sejam uma opção. O último princípio básico é trabalho de qualidade, pois uma das necessidades secundárias dos seres humanos 
é obter satisfação por ter a oportunidade de realizar trabalhos bem feitos. Além desses princípios básicos, alguns princípios menos importantes são os seguintes: ensinar a aprender, começar com investimento pequeno, jogar para ganhar, experimentos concretos, comunicação honesta e aberta, trabalhar com os instintos das pessoas, responsabilidade aceita, adaptação local, viajar sem peso e medidas honestas.

$\mathrm{Na}$ equipe observamos quatro papéis principais: os programadores, o cliente, um treinador e um acompanhador, além de eventuais consultores.

O papel de treinador é importante para uma equipe conseguir mudar sua cultura de desenvolvimento e se adaptar à metodologia corretamente. As práticas de XP demandam muita disciplina e o treinador é a pessoa responsável por ensiná-las à equipe e garantir que sejam executadas corretamente.

O acompanhador mantém dados e usa métricas relativas ao andamento do processo e a qualidade dos artefatos gerados, seu trabalho é essencial como suporte ao treinador. Comunicando as medidas à equipe, consegue manter todos conscientes de como o trabalho está progredindo de fato e onde e como pode-se melhorar.

As práticas da primeira versão, todas contempladas na segunda, são:

- jogo do planejamento

- releases pequenos

- metáfora

- design simples

- testes automatizados

- refatoração

- programação pareada

- propriedade coletiva do código

- integração contínua

- ritmo sustentável

- cliente sempre presente

- padrão de codificação 
O desenvolvimento é feito em ciclos de algumas semanas, chamados de iterações. Cada iteração produz software funcional, integrado e testado, contendo as funcionalidades mais necessárias aos clientes. Releases pequenos contém algumas iterações, mas por serem curtos, duram no máximo um mês. Ao entregar um release, o software deve ser colocado em produção. A sobrecarga de trabalho é evitada selecionando para a iteração uma carga de trabalho com a qual a equipe se compromete de fato. Além disso, as iterações tentam adotar um ritmo sustentável de trabalho, evitando a prática de hora-extra.

Os requisitos do programa são colhidos durante o jogo do planejamento, quando o cliente escreve histórias que podem ser implementadas em um release. Cada história é anotada em um cartão com um pequeno texto que descreve uma funcionalidade desejada. Cientes de que o cliente nem sempre sabe exatamente o que ele deseja e que raramente pode negociar o tempo ou o custo de um projeto, durante esta atividade os programadores e os clientes negociam o escopo do software que será entregue construindo metáforas comuns para facilitar a comunicação. Os programadores são responsáveis por estimar quanto tempo de desenvolvimento cada história necessita e os clientes por priorizar as histórias que serão entregues em uma iteração. Ao final de um release, uma reunião é realizada com o intuito de repriorizar histórias.

O desenvolvimento de uma iteração se dá por equipes de dois programadores, que se alternam ao longo do tempo, e com a presença constante do cliente e apoio do treinador. A equipe realiza reuniões diárias para se organizar. Os programadores escrevem código para funcionalidades que podem ser implementadas em períodos curtos de tempo, buscando sempre manter o design simples. O código é produzido de acordo com o padrão de codificação estabelecido pela equipe, é integrado constantemente e conta com uma cobertura de testes automatizados, de unidade e de aceitação, esses últimos escritos em colaboração com o cliente. Existe propriedade coletiva do código. Qualquer parte do software pode ser alterada por qualquer par e refatorações constantes são efetuadas para manter o design da aplicação o mais simples possível. O espaço de trabalho deve ser configurado para permitir a programação pareada e valorizar a comunicação, tendo quadros brancos e espaço para o acompanhador colocar cartazes informativos.

As regras de XP não são absolutas. Sabendo que cada empresa tem sua própria cultura, XP é ágil o suficiente para poder ser adaptada aos diferentes contextos. As práticas não precisam ser seguidas à risca e nem em totalidade (porém, algumas combinações, como refatorar sem testar, não são recomendadas) e nada impede que desvios ocorram eventualmente ou que outros padrões sejam utilizados em conjunto com a metodologia.

\subsection{XP - Por que funciona?}

Ao redefinir a metodologia na segunda versão de seu livro, Beck se concentra nas razões que fazem XP funcionar. A nova definição revela a principal dificuldade em implantar a metodologia em qualquer contexto: 
"Programação eXtrema (XP) trata de mudança social"

(BECK, 2004, p.1)

É muito difícil efetuar esta mudança ao adotar XP em uma organização, pois significa deixar para trás velhos hábitos e padrões e abandonar defesas que nos protegem, mas interferem na nossa produção, como o receio de mostrar código produzido para avaliação dos colegas. Beck sugere que o sucesso é fruto de boas relações humanas e alguma técnica. Em XP, ser sincero sobre a capacidade de produção e então produzir aquilo que foi planejado, crescendo ao mesmo tempo que nos relacionamos com outros, implica melhores relações humanas na sua organização e, conseqüentemente, bons negócios. XP alinha muita comunicação e trabalho em equipe com algumas técnicas de programação para produzir software de qualidade entregue no tempo certo.

A metodologia tem quatro componentes. Em primeiro lugar, uma filosofia com valores bem definidos. Uma organização disposta a mudar deve valorizar a comunicação, o feedback, a simplicidade, a coragem e o respeito.

Em segundo lugar, ferramentas que traduzem os valores em práticas concretas pelas quais um grupo pode se responsabilizar. São os princípios de XP:
- humanidade
- fluxo
- economia
- oportunidade
- benefício mútuo
- redundância
- auto-semelhança
- falha
- melhoria
- qualidade
- diversidade
- pequenos passos
- reflexão
- responsabilidade

Em terceiro lugar, temos as práticas que expressam os valores e seguem os princípios, complementandose e amplificando-se: 
- sentar juntos

- time completo

- área de trabalho informativa

- trabalho energizado

- programação pareada

- histórias

- ciclo semanal

- ciclo de estação

- folga

- build veloz

- integração contínua

- desenvolvimento dirigido por testes
- design incremental

- envolvimento real com o cliente

- implantação incremental

- continuidade do time

- redução do time

- análise da causa inicial

- código compartilhado

- código e testes

- repositório único de código

- implantação diária

- contrato de escopo negociável

- pague pelo uso

Em quarto lugar, temos uma comunidade que compartilha esses valores, princípios e práticas.

XP é diferente de métodos tradicionais em diversos pontos. Possui um ciclo de desenvolvimento curto baseado num planejamento incremental de escopo negociável. Além disso, o progresso é monitorado através da evolução de testes automatizados que garantem o funcionamento do software. A equipe prioriza a comunicação oral, os testes e o código fonte para entender e trabalhar com o sistema. O processo de design é incremental, buscando manter o ritmo de entrega de software contínuo e a aplicação simples e funcional durante toda a vida do sistema. XP cria um ambiente de colaboração próxima e engajada, no qual as práticas funcionam de acordo tanto com os instintos de curto prazo da equipe, quanto nos interesses de longo prazo do projeto.

A nova descrição de XP diz que a metodologia é leve, para qualquer tamanho de time, dá enfoque às restrições do desenvolvimento de software e se adapta a requisitos vagos ou mutantes. Isso implica que todos fazem XP de maneira diferente e com diferentes graus de sucesso. O único caso em que XP não se aplica é quando uma organização não consegue ou não pode mudar seus valores.

Aos programadores, a mensagem é que XP funciona se você perceber que não é seu trabalho administrar as expectativas dos outros e sim fazer o seu melhor e comunicar-se com freqüência e clareza, jogando para vencer e aceitando responsabilidade.

$\mathrm{XP}$ adota como pressuposto que as pessoas fazem parte de um time, querem trabalhar juntas e se aperfeiçoar, estão dispostas a mudar e que estas mudanças não custam nada, ou custam pouco.

XP funciona porque lida com os riscos do desenvolvimento de software. Limita atrasos com implantação diária, ciclos semanais que oferecem feedback granular do progresso e o desenvolvimento da maior prioridade do cliente primeiro. Evita o cancelamento do projeto ao entregar o menor release possível com o maior valor agregado, sempre. Evita que o sistema se torne defeituoso mantendo uma bateria de testes automáticos e integrando código fonte continuamente de forma que o software esteja pronto para implantação. Lida com defeitos tanto com testes de unidade quanto com testes de 
aceitação. Lida com erros de negócio ao ter envolvimento real do cliente que aprende e evolui junto com o time completo. Se adapta a mudanças de negócios com implantação diária e ao possibilitar mudanças no plano durante um ciclo de desenvolvimento. Evita o excesso de funcionalidades que não trazem benefícios diretos ao só implementar histórias de alta prioridade escritas pelo cliente. Lida com a alta rotação de trabalhadores criando um ambiente de convívio agradável e menos estressante. Ao trabalhar com estimativas feitas pelos próprios desenvolvedores, pelas quais eles se responsabilizam, e ao incentivar o contato humano, evita a evasão de membros da equipe devido a frustrações ou estresse. Ao incentivar o ingresso de novatos na equipe, XP acolhe novos membros com tranqüilidade.

\subsection{Valores}

A seguir iremos apresentar os valores da Programação eXtrema e fazer uma breve análise de cada.

\subsubsection{Comunicação}

O desenvolvimento de software é uma atividade complexa. Por mais simples que seja um programa, no mínimo duas pessoas estão envolvidas em sua implementação: um programador e um cliente. Mesmo os sistemas mais simples requeridos pelo mercado normalmente exigem uma equipe de programadores trabalhando em conjunto. Por isso, valorizar a comunicação é muito importante. XP pretende manter o custo de tempo e energia para descobrir uma informação baixo e a taxa de dispersão da informação alta.

Sempre que mais do que uma pessoa está trabalhando em alguma tarefa, a eficiência e eficácia de um projeto está diretamente ligada à qualidade da comunicação entre estas pessoas. A grande maioria dos processos existentes valoriza a comunicação; o problema é que muitas metodologias acreditam que a dificuldade de comunicar-se pode ser resolvida com documentação escrita, extensa e completa. XP inova ao priorizar a comunicação pessoal e oral, acreditando que falar é melhor do que escrever. Ao estar em contato presencial com uma pessoa, sinais sutis como a linguagem corporal podem enriquecer muito a comunicação. Além disso, este contato permite que as dúvidas sejam resolvidas e discutidas logo que surgem. Já a documentação escrita sempre tende a desatualizar-se rapidamente.

Estudos recentes [EK06] mostram que a comunicação verbal é mais eficiente do que a comunicação escrita, pois ao escrever, uma pessoa corre o risco de assumir que certas sutilezas serão percebidas pelo leitor, devido a um fenômeno psicossocial bem estabelecido: o egocentrismo, que diz que pessoas tem dificuldades em se distanciar de suas próprias perspectivas e entender como serão interpretados por outros.

A comunicação é valorizada em XP de diversas maneiras. Uma das práticas sugeridas pela primeira versão da metodologia e defendida por Beck é criar uma metáfora comum para facilitar a compreensão [Bec02b]. Encontros pessoais entre os desenvolvedores e o cliente acontecem freqüentemente, durante os jogos de planejamento e as reuniões de avaliação das iterações. O cliente sempre 
presente permite que desenvolvedores resolvam questões sobre requisitos ou validem a implementação de funcionalidades imediatamente.

Os desenvolvedores devem trabalhar no mesmo espaço, fazendo pequenos encontros diários, para planejar quais tarefas serão executadas por quais pares. Além disso, verifica-se o andamento do dia anterior.

O espaço de trabalho tem uma função importante na comunicação e é explorado na metodologia através do uso de cartazes informativos espalhados pelas paredes. Estes cartazes contêm representações das métricas do projeto: são os chamados radiadores de informação [Coc02]. Através destes cartazes, os desenvolvedores e até mesmo o cliente podem rapidamente absorver informações ligadas ao andamento do projeto. A qualidade do processo é avaliada constantemente e comunicada de maneira quase osmótica.

A programação pareada, ou programação em pares, com pares de pessoas que se alternam ao longo do tempo trabalhando em todo o código e integrando-o freqüentemente, contribui para que o design e a implementação do software sejam transmitidos de maneira tácita por toda equipe.

Finalmente, o fato das equipes de XP serem pequenas (de no máximo 12 desenvolvedores, sendo 12 o limite natural de pessoas com as quais uma pessoa consegue manter comunicação confortavelmente durante um dia [BA04]), permite que a comunicação pessoal seja de fato eficiente. Equipes maiores necessitam de controles mais rígidos e comunicação mais estruturada. Veremos porém que XP pode escalar, mas isso será discutido na seção sobre a nova versão.

A comunicação é o valor que tem mais importância em uma equipe de desenvolvedores, essencial para uma sensação de pertinência e cooperação efetiva.

\subsubsection{Simplicidade}

Os desenvolvedores de software conhecem a regra 80 - 20 ou Princípio de Pareto: $80 \%$ das conseqüências são fruto de $20 \%$ das causas. Justamente por essa razão que deve-se valorizar a simplicidade. Um sistema com muitas funcionalidades tem quase todo seu valor em $20 \%$ destas, manter o sistema simples e sempre implementar as história de maior prioridade evitam o fracasso. XP diz que manter o sistema simples é essencial para não gerar mais trabalho. Desenvolvedores não devem generalizar sem necessidade, ou supor necessidades. Devem implementar da maneira mais simples possível os requisitos mais prioritários. Por ter autonomia de mudar qualquer parte do código, os programadores estão sempre atentos a oportunidades de refatorar o software com o objetivo de simplificá-lo.

Manter um sistema simples é uma atividade intelectual intensa, que requer esforço de todos e, justamente por isso, depende do contexto. Uma equipe com desenvolvedores experientes pode achar simples uma solução de design que usa padrões de projeto como Observer, enquanto que se a equipe tiver pessoas que não conheçam o padrão, esta solução deixa de ser simples. 
Simplicidade e comunicação são valores complementares. Quanto mais simples o sistema, menos precisa ser comunicado e quanto maior a comunicação, maior o entendimento e portanto mais fácil a manutenção da simplicidade.

\subsubsection{Feedback}

Feedback é valorizado pois a equipe que faz XP é ágil. Para poder mudar o plano e se adaptar, precisa saber rapidamente e com exatidão o que está acontecendo. Ao longo do desenvolvimento, é muito importante receber feedback do cliente, a fim de avaliar se o software está de acordo com suas necessidades. Com releases rápidos e freqüentes, ao ver o software funcional, o cliente pode entender o que ele realmente precisava, mudar de idéia, ou descobrir requisitos dos quais ele não estava ciente.

Durante os encontros de avaliação e planejamento, o cliente recebe feedback dos desenvolvedores quanto às implicações de implantar seus requisitos, incluindo informação sobre quanto tempo a implantação deve consumir. A equipe então recebe feedback sobre quais funcionalidades devem ser priorizadas, podendo alterar o software a tempo de manter o valor para o cliente.

Programação pareada também permite que os programadores recebam feedback imediato de seus pares sobre o código que estão produzindo. Este processo de inspeção contínua comprovadamente [Tom02a, LC03b, HA05] reduz a freqüência de erros e aumenta a produtividade de ambos programadores.

Testes automatizados provêm feedback imediato sobre o funcionamento do software aos desenvolvedores. É este feedback que permite que refatorações do software sejam efetuadas com baixo risco. Além disso, muito feedback pode ser recebido através de ferramentas de desenvolvimento. Ao usar um ambiente de desenvolvimento integrado, como o Eclipse por exemplo, feedback sobre o código produzido é recebido em tempo real, erros de sintaxe são detectados e corrigidos imediatamente, quase automaticamente.

O acompanhador analisa e disponibiliza diferentes métricas sobre o desenvolvimento à equipe; este feedback contínuo permite que todos conheçam a realidade do projeto e do processo. Quando o desenvolvimento demora mais tempo do que estimado, a equipe fica sabendo disso e pode notificar o cliente a tempo, possibilitando que o escopo de um release seja renegociado.

Valorizar o feedback é ter satisfação em melhorar e saber que não existe perfeição instantânea. É também valorizar comunicação. Simplicidade também contribui com o feedback: quanto mais simples um sistema, mais fácil é obter feedback sobre seu design e implementação.

\subsubsection{Coragem}

Desenvolvimento de software nos dias de hoje é um processo que causa medo. Tanto o cliente como os desenvolvedores têm muitos medos. XP lida com esses medos ao fornecer o suporte necessário para que as pessoas possam sentir coragem para agir e tomar decisões. As práticas de XP se apóiam, 
dando confiança à equipe. Os programadores podem ter coragem de refatorar, pois sabem que os testes irão detectar erros imediatamente. O cliente pode decidir com mais coragem, quando avalia o software funcional após cada release, sabendo que pode priorizar as funcionalidades que lhe são mais importantes. No jogo do planejamento, são os desenvolvedores que estimam as funcionalidades, podendo ter confiança de que irão entregar o que estão prometendo ao cliente a tempo. Ao ter controle do próprio processo, os desenvolvedores têm consciência da velocidade na qual trabalham, podendo encarar a necessidade de retrabalho com coragem.

Coragem pode ser perigosa se não balanceada com os outros valores. É fácil ter coragem de não documentar o código, porém se a comunicação não for valorizada, essa estratégia expõe a equipe a riscos altos. Coragem para falar valoriza comunicação e confiança. Coragem de descartar código valoriza a simplicidade. Coragem de buscar respostas valoriza o feedback.

\subsection{Práticas}

As doze práticas são simples, porém a riqueza da metodologia provêm da combinação delas. Poucas práticas se sustentam individualmente, pode inclusive ser perigoso adotar uma prática sem que seus defeitos possam ser compensados pelas práticas que a apóiam. A Figura 2.1 mostra um grafo das relações entre as práticas:

A seguir iremos apresentar as doze práticas da primeira versão de XP, explicitando, para cada uma delas, as relações com as outras práticas já apresentadas.

\subsubsection{Jogo do planejamento}

Não importa quais precauções alguém pode tomar, seu plano nunca andará exatamente de acordo com o que foi planejado [KB01]. O Jogo do Planejamento é a prática de sempre revisar o plano, com uma freqüência constante de encontros nos quais os desenvolvedores e os clientes devem entender o que foi feito, o que não foi feito e o por quê, além de qual o novo plano a se seguir. É uma prática que descreve alguns processos, explicitando atividades a serem realizadas pela equipe regularmente.

Beck e Fowler [KB01] discutem em detalhes como planejar um projeto XP, citando três razões para realizar o planejamento:

1. Precisamos ter certeza que sempre estamos trabalhando na coisa mais importante que temos para fazer.

2. Precisamos estar coordenados com outras pessoas.

3. Quando um evento inesperado ocorre, precisamos entender as conseqüências para as duas primeiras.

As atividades do jogo do planejamento envolvem os programadores, o treinador, o acompanhador 


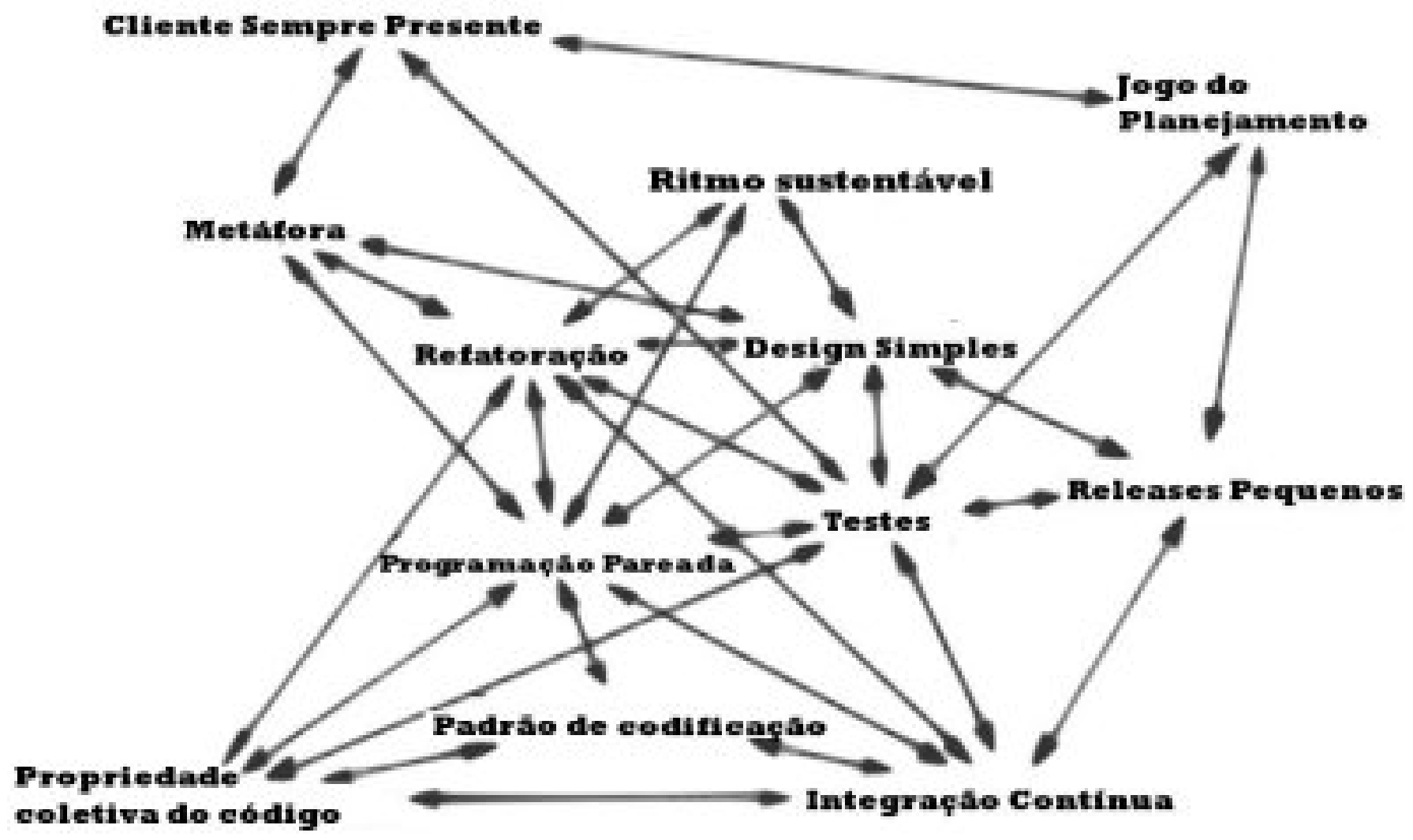

Figura 2.1: Diagrama explicitando um grafo de relações de apoio mútuo entre as práticas (BECK, 1999)

e o cliente, porém Beck [Bec99] deixa claro que somente duas forças atuam nesse jogo: o desenvolvimento e o negócio em uma relação de respeito e benefício mútuo. Normalmente, o trabalho do treinador é ajudar o cliente a escrever histórias e intermediar o jogo com a equipe de desenvolvimento. O treinador apóia a equipe com dados relativos ao desempenho mais recente de todos membros dessa. É com base nesses dados que os desenvolvedores são capazes de estimar o tempo necessário para concluir uma história. Martin Fowler [Fow01] nomeia este padrão de "clima de ontem".

William Wake [Wak02] descreve o jogo do planejamento como composto de dois processos: o planejamento de um release e o planejamento das iterações deste release. O primeiro processo se dá em duas etapas: a etapa de exploração e a etapa de planejamento. Na etapa de exploração, o negócio é representado pelo cliente, que escreve e reescreve histórias. Os programadores estimam histórias e escrevem spykes: pequenos protótipos que serão descartados. A atividade pode ser resumida da seguinte forma:

- O cliente escreve as histórias que gostaria de ver no release.

- Os programadores estimam o tempo necessário para concluir a história.

- Se a história for muito grande, os desenvolvedores pedem ao cliente para rescrevê-la, quebrando- 
a em histórias menores.

- Se os desenvolvedores não sabem estimar a história, eles partem para o desenvolvimento de um spyke para ter uma base sobre a qual podem estimar.

Ao final desta fase, que pode durar de alguns dias a uma semana, todas as histórias do release estão estimadas. Pode-se então iniciar a etapa do planejamento das iterações que compõem um release, que normalmente dura algumas horas.

Com todas as histórias em mãos, o cliente avalia o valor de cada história, priorizando aquelas que dão o maior retorno ao seu negócio. O acompanhador então, usando dados da última iteração, declara a velocidade da equipe. Ou seja, baseando-se no desempenho passado, sabendo a estimativa das histórias e também o tempo real que elas levaram e comunicando estes dados à equipe, podemos ter uma idéia de quantas histórias poderão ser realizadas em uma nova iteração. O cliente então escolhe as histórias que devem compor o escopo do release. Somando suas estimativas e usando a velocidade calculada pelo acompanhador, sabemos dizer quantas iterações são necessárias para completar o release. O escopo pode ser negociado baseado nessas informações, o cliente pode mudar as histórias que deseja para obter o release mais cedo, por exemplo.

O segundo processo é o planejamento de uma iteração. Este processo ocorre ao começo de cada iteração e é também composto por duas fases: um brainstorming inicial e a fase de aceitação de tarefas. Durante a primeira fase, os desenvolvedores, na presença do cliente, pegam as histórias planejadas para a iteração e escrevem, para cada história, tarefas concretas a serem realizadas. Cada desenvolvedor, com a ajuda do acompanhador, sabe quanto trabalho consegue realizar em uma iteração. Durante a segunda fase esse conhecimento é importante, pois os desenvolvedores assumem tarefas e estimam o tempo necessário para completá-las. Enquanto que para estimar histórias toda a equipe participa, ao estimar uma tarefa é o desenvolvedor que a aceitou que deve dizer o tempo necessário. Este processo ocorre em paralelo, até todos os desenvolvedores terem uma carga de trabalho balanceada para a iteração.

Além destes dois processos, o jogo do planejamento descreve mais duas atividades: a validação de uma iteração e, opcionalmente, o replanejamento de um release. Ao final de cada iteração o cliente deve se encontrar com os desenvolvedores para validar o código escrito, rodando todos os testes funcionais das histórias previstas na iteração. O cliente tem a opção de aceitar ou não os resultados da iteração. Os desenvolvedores podem explicar por que estimativas estouraram, se isso de fato ocorreu e avisar se algum problema inesperado foi detectado. Dependendo do resultado deste encontro o cliente tem a oportunidade de replanejar o release atual. Se necessário, deve repriorizar histórias marcadas para as próximas iterações, resgatar histórias que não foram validadas para que continuem sendo desenvolvidas, ou até mesmo criar novas histórias. É importante notar que estimativas e prioridades de histórias não são absolutas, o cliente deve tentar adiar as decisões o máximo possível, mas não mais tarde do que isso, para baseá-las na melhor informação disponível. 
O jogo do planejamento pode sofrer variações, adaptando-se melhor ao contexto cultural da organização onde XP está sendo aplicada. Esta prática valoriza diretamente o feedback, pois este ocorre com freqüência, dando mais oportunidades para o cliente mudar de plano, além de usar medidas de iterações anteriores e spykes para melhorar o processo de estimativa. Ao ditar que os desenvolveres são donos das estimativas, a prática valoriza a coragem. A equipe sabe que prometeu ao cliente exatamente aquilo que pode cumprir. A comunicação é valorizada durante todo processo de exploração, no qual a presença contínua do cliente e seu diálogo com os desenvolvedores é essencial para construir estimativas reais e para que a equipe entenda muito bem os requisitos.

\subsubsection{Releases pequenos}

A prática de releases pequenos define o ritmo dos eventos que marcam o progresso em um projeto XP. O progresso se dá pela entrega de software funcional: um release que deverá ser colocado em produção pelo cliente. A entrega deve agregar o máximo de valor para o cliente com a menor quantidade possível de código novo. O ciclo entre entregas deve ser freqüente e o mais curto possível, sendo a única restrição a de que o sistema entregue deve fazer sentido como um todo.

Releases pequenos aumentam o feedback que a equipe recebe quando o cliente avalia a produção que foi planejada. São também feedback direto para o cliente, que vê quanto progresso foi feito e pode usar informações recentes para mudar prioridades ou até mesmo criar histórias novas para o próximo release. É importante que o cliente use de fato a nova versão do software após cada release.

Além de valorizar o feedback, esta prática também valoriza a comunicação, pois o sistema funcional comunica ao cliente exatamente quais requisitos foram implementados. Valoriza também a coragem, pois ao estabelecer um ritmo de entregas tanto o cliente sente mais coragem com a evolução incremental do sistema, quanto os desenvolvedores sentem coragem sabendo que irão manter um ritmo de entregas funcionais. Sendo pequenos e contendo somente as funcionalidades de maior prioridade, os releases pequenos também valorizam a simplicidade.

Esta prática é apoiada pelo jogo do planejamento, que ajuda a priorizar as histórias de mais valor, fazendo com que até mesmo um sistema pequeno tenha valor para o negócio.

\subsubsection{Metáfora}

Metáfora é a prática que diz que a equipe de desenvolvimento deve usar um "sistema de nomes" mapeando os elementos do sistema a nomes de objetos do mundo real. A metáfora facilita a comunicação entre os desenvolvedores e também facilita a comunicação dos desenvolvedores com o cliente. Ela descreve uma atividade que deve ser exercida na interação entre os papéis do cliente e dos programadores.

Um bom exemplo de metáfora está no software de folha de pagamento da Chrysler, no qual os componentes do sistema foram nomeados como componentes e partes de uma fábrica. Essa escolha funcionou bem pois, além dos desenvolvedores, outras pessoas na organização entendiam bem os 
conceitos de uma fábrica (a Chrysler é uma fábrica de automóveis). O sistema de nomes continha "peças" como a "peça salário", que seguiam em diferentes "linhas de montagem", transportadas em "baldes" e processadas em diferentes "estações", calcular a folha de pagamento não é algo que pode ser trivialmente comparado a uma fábrica, mas esta metáfora contribuiu para que tanto os desenvolvedores, quanto o cliente, entendessem o sistema em toda sua complexidade.

A metáfora ajuda todos os envolvidos a terem uma visão comum do sistema, seus elementos, como eles funcionam e como poderiam funcionar. Também provê um vocabulário comum. Ao se referir à metáfora, tanto o cliente, quanto os desenvolvedores, podem entender o que o outro quer comunicar. Não importa se o cliente está pensando em uma regra de negócio enquanto os desenvolvedores estão pensando em um objeto do sistema. Desta maneira a metáfora valoriza a comunicação. A metáfora também ajuda a explorar os limites do sistema, valorizando o feedback, pois ao explorar a metáfora, o time pode descobrir fatos que não sabia sobre o sistema, ou pode ter idéias novas.

A metáfora é usada para guiar o design e para entender como classes de objetos se relacionam. Escolher uma metáfora boa é um trabalho contínuo, que começa na fase de exploração e faz parte da comunicação diária. É importante que o time todo concorde com a metáfora.

A metáfora também valoriza a simplicidade ao tentar explicar de maneira fácil um sistema que pode ser complexo e ao facilitar o entendimento do sistema como um todo tanto pelos desenvolvedores quanto pelo cliente.

\subsubsection{Design simples}

Faça a coisa mais simples possível. Esta é a estratégia principal da prática de design simples que diz que o programador deve sempre se esforçar para manter o design da aplicação simples e ao mesmo tempo evitar complexidade ou flexibilidade desnecessária até o momento em que esta se torne crucial. O design mais simples a qualquer momento é aquele que passa em todos os testes, não contém lógica duplicada, esclarece todas intenções aos programadores e tem o menor número possível de classes, métodos e linhas de código. É uma prática que determina um processo contínuo de avaliação da qualidade do código fonte gerado pelo desenvolvimento.

Se o design é simples, adicionar funcionalidades também será simples. Ao evitar código duplicado, quando surge a necessidade de adicionar algo, será necessário alterar somente uma parte do programa e será fácil descobrir onde se o design demonstra claramente todas as intenções aos programadores. O design simples facilita localizar onde e perceber como deveremos alterar o programa. Ao mesmo tempo, ao rodar todos os testes com o mínimo de classes e métodos, garantimos que não existe desperdício ou redundância negativa no sistema.

Esta prática valoriza, obviamente, a simplicidade e também a comunicação e o feedback, pois o design simples comunica de maneira mais fácil as suas intenções aos programadores. Ao manter a simplicidade, valorizamos também a coragem, pois mudanças podem ser feitas com mais facilidade. 
Design simples é uma prática que corrobora releases pequenos, é a simplicidade do design que garante que ao ter uma aplicação que faz só o suficiente para uma entrega, as entregas podem ser realizadas com mais freqüência. Ao mesmo tempo, a prática da metáfora possibilita que mudanças no design se mantenham consistentes e que o design da aplicação como um todo tenda a convergir e manter-se simples.

\subsubsection{Testes automatizados}

Para garantir a qualidade do software construído é essencial a presença de testes automatizados que validem o seu funcionamento. Estes testes aumentam a confiança tanto dos programadores quanto do cliente de que o sistema funciona de fato. Esta prática define que testes são artefatos produzidos por uma equipe XP como atividade diária, tanto na interação entre programadores, quanto na interação com o cliente.

Esta prática incentiva a construção de testes de unidade automatizados, que testam cada componente do sistema individualmente, escritos pelos programadores para cada funcionalidade dos componentes. Beck sugere que o desenvolvimento seja orientado por testes [Bec02a]: programadores devem primeiro escrever um teste que falha para qualquer funcionalidade, depois fazê-lo passar, refatorando o código para remover duplicação, repetindo este ciclo até ter todas as funcionalidades testadas. A todo momento, todos testes de unidade devem passar.

Testes de funcionalidade, também conhecidos como testes de aceitação, fazem parte desta prática. Estes validam o sistema como um todo do ponto de vista das necessidades do cliente e, de preferência, devem ser escritos pelo próprio cliente com a ajuda de um desenvolvedor. Os testes de funcionalidade aumentam a probabilidade que os requisitos do cliente estão sendo cumpridos e são uma ferramenta para que o cliente acompanhe o progresso do projeto. Quando todos testes de funcionalidade passarem, o sistema está pronto. Testes de funcionalidade também devem ser automatizados.

Esta prática valoriza o feedback, pois os testes mostram o estado atual de funcionamento do sistema. Valoriza também a coragem, pois ao passar, os testes diminuem a probabilidade de erros [LC04, GW04], dando mais segurança à equipe de que o sistema está funcionando.

O design simples facilita a escrita dos testes: se o código evita acoplamento e mantém alto nível de coesão, criar testes de unidade é fácil. O fato de testes serem feitos durante o desenvolvimento e não em uma fase final, ajuda na prática de manter os releases pequenos.

\subsubsection{Refatoração}

Refatoração [Fow99] é a técnica de melhorar algum aspecto não funcional do código fonte de um programa. O objetivo é criar código mais simples de ler e entender, melhorando o design. A prática de refatoração contínua incentiva os programadores a ficarem atentos a oportunidades de melhorar o software através da refatoração, definindo um processo contínuo. Essas oportunidades ocorrem quando se deve adicionar algo novo ao programa. Antes de implementar um novo requisito, 
verificamos se existem oportunidades de simplificar o design para facilitar esta implementação. Após adicionar o requisito, também temos a oportunidade de refatorar o código e torná-lo ainda mais simples. A refatoração contínua valoriza a simplicidade e a comunicação.

Existem catálogos de refatorações que listam refatorações comuns que podem ser aplicadas no dia-a-dia [Fow99,Ker05]. Eles apresentam motivações para cada refatoração, uma mecânica que lista pequenos passos que devem ser seguidos para executar a refatoração e exemplos práticos. Um bom programador se acostuma a identificar sintomas de que o código precisa ser refatorado, chamados de mau cheiros, tais como classes muito grandes, métodos muito grandes, comentários demais e, principalmente, código duplicado. Algumas refatorações são simples e implicam somente em mudança de nomes de variáveis, parâmetros ou classes. Outras implicam a aplicação de padrões de design orientado a objetos [GHJV95]. Existem ainda técnicas para refatorar bancos de dados [AS06]. É altamente recomendável o uso de ferramentas de refatoração que facilitam a adoção da prática automatizando a mecânica da maioria das refatorações.

A prática de refatoração enfatiza a evolução da metáfora: ao refatorar continuamente, refina-se o entendimento do que a metáfora significa na prática.

Manter o design simples é possível com o apoio da prática de refatoração. Ao usar técnicas de refatoração conseguimos mudar o design, simplificando-o sem os medos e as preocupações normalmente associadas a esta atividade. Ao mesmo tempo, o fato do design ser simples, facilita refatorações.

A prática de testes automatizados é essencial para a refatoração, os testes são a garantia que a refatoração não afetou o funcionamento do programa.

\subsubsection{Programação pareada}

A prática de programação pareada, ou programação em pares, demanda que todo código fonte que será entregue ao cliente seja produzido por um ou mais pares de programadores, sendo que cada par deve atuar na atividade ao mesmo tempo. Inicialmente, dizia-se que o par deveria usar o mesmo computador, porém variantes surgiram nos quais o par pode usar uma só máquina, usar uma máquina com dois teclados e mouses, ou então compartilhar a mesma sessão de trabalho em duas máquinas diferentes, podendo estar situados em um mesmo local ou até mesmo trabalhando à distância. Uma equipe de Programação eXtrema é sempre composta por um grupo de pares, cada par é mais produtivo e cria mais código de maior qualidade do que se as pessoas programassem individualmente [LC03b]. Programação pareada define como os programadores devem interagir diariamente. A eficácia desta técnica já foi comprovada até mesmo em contextos que não utilizam as outras práticas de XP [CW00].

Ao iniciar uma sessão de programação pareada, o par deve discutir as tarefas que serão executadas relativas à história que estão implementando. Após chegar a uma estratégia comum, o par alterna de papéis durante o tempo em que trabalha junto. Uma das pessoas assume o papel de "motorista", controlando o teclado e o mouse e concentrando-se no código que será escrito. A outra pessoa 
assume o papel de "chapa" e ajuda o motorista no seu trabalho, pensando sobre todas implicações do código que está sendo escrito de maneira mais estratégica, sugerindo testes e ficando atento a pequenos erros que o motorista talvez não perceba. Esta atividade é intensa para ambos os papéis e a comunicação é importante para que seja executada com harmonia, aproveitando ao máximo o empenho de ambos indivíduos. Ao longo de uma iteração, pares são criados entre todos membros da equipe. Isso implica que mais pessoas entendem o sistema de maneira mais completa do que se elas trabalhassem individualmente.

Programação pareada valoriza principalmente a comunicação, especialmente ao fazer um rodízio entre os membros de todos os pares, alternando pessoas entre os pares com certa freqüência, para que o conhecimento sobre as diferentes partes do sistema seja compartilhado entre todos membros da equipe e a diversidade do time seja potencializada. Esta prática também valoriza a coragem, pois duas pessoas tem mais coragem do que uma e valoriza o feedback através do diálogo ativo entre o par.

Programação pareada é uma prática que influencia o design simples: duas pessoas trabalhando no mesmo problema aumentam as chances de que o design seja de fato simples e não simplório. Ao mesmo tempo, a simplicidade garante que ambos possam compreender o que está acontecendo durante a implementação.

Esta prática também apóia a prática de testes, ao responsabilizar o chapa a pensar em novas idéias para testes que podem ser feitos no código escrito pelo motorista. Ao mesmo tempo, a prática de pensar em testes em conjunto ajuda ambos a alinhar seu entendimento do problema antes de ter que resolvê-lo. A programação pareada também ocorre quando um programador ajuda o cliente a escrever testes de aceitação.

Ao trabalharem em pares (ou "parear"), uma dupla sente mais coragem para refatorar. Ainda mais com a redundância de duas pessoas concentrando-se no mesmo código, diminui a probabilidade de que alguma parte do sistema seja quebrada, ou seja, deixe de funcionar, durante refatorações.

A prática da metáfora também ajuda na programação pareada, fazendo com que seja mais fácil para uma dupla chegar a um acordo de como desenhar o sistema e como nomear os objetos criados.

\subsubsection{Propriedade coletiva do código}

Esta prática implica que todo o código fonte pertence a todos programadores da equipe e qualquer um tem a liberdade de alterar qualquer parte dele, mesmo se não foi o seu autor original. Além disso, pares devem estar atentos a oportunidades de melhoria do código e executá-las sempre que forem detectadas. Esta prática define mais uma maneira de como desenvolvedores interagem.

Como alternativa a outros modelos de propriedade de código, a propriedade coletiva valoriza a comunicação e a colaboração. Esta prática incentiva o compartilhamento de conhecimento e, ao mesmo tempo, reduz o risco de alguma parte do software depender exclusivamente da pessoa que o 
criou. Ela também promove maior qualidade e agilidade, pois toda equipe conhece todo o código e pode mudá-lo sem hesitar quando detecta uma oportunidade para melhoria ou percebe a necessidade de alterações.

Ao praticar propriedade coletiva do código a equipe toda obtém algum conhecimento sobre o sistema por inteiro, ao mesmo tempo em que alguns tem mais conhecimento sobre as partes específicas em que trabalharam. O contato com todo o código fonte do sistema que ocorre graças a esta prática é feedback que os desenvolvedores obtém sobre o design e a arquitetura da aplicação. Desta maneira esta prática valoriza o feedback. A prática também valoriza a coragem e a simplicidade ao incentivar todos a mudarem o código quando ele pode ser mais simples.

Ao praticar a refatoração os desenvolvedores devem estar atentos a qualquer melhoria que possa ser feita no código fonte. A prática de propriedade coletiva do código dá coragem aos pares que identificam a necessidade de mudanças em código que não tinham escrito originalmente. Além de apoiar a refatoração, esta prática corrobora a programação pareada ao diminuir possíveis disputas entre pares relacionadas à propriedade de um pedaço de código. Ao mesmo tempo, ao parear, programadores conseguem aprender mais rápido partes desconhecidas do sistema e também como alterá-las de maneira proveitosa. Duas pessoas atentas às modificações diminuem a chance de algo quebrar durante alterações.

Testes automatizados também enfatizam esta prática, pois aumentam a probabilidade de que eventuais mudanças não alteram o funcionamento do sistema.

\subsubsection{Integração contínua}

Esta prática tem como objetivo garantir que todo código produzido será integrado a um repositório comum com a maior freqüência possível: após algumas horas de desenvolvimento ou um dia no máximo. Desta maneira, criar uma versão do software com todas as mudanças recentes e encaminhála ao cliente torna-se uma atividade simples e que pode ser inclusive automatizada.

Ao integrar, é importante verificar se não existem conflitos e que todos os testes de unidade estão sendo bem-sucedidos. Garante-se desta maneira que as novas funcionalidades não tiveram impacto negativo no resto do sistema. Ao mesmo tempo, fica claro de quem é a responsabilidade de fazer o sistema funcionar, pois se os testes fracassam a causa é obviamente o código que acabou de ser integrado. Testes automatizados apóiam e facilitam a prática de integração contínua.

Esta prática pode ser aplicada de diversas maneiras; o importante é manter o processo de build do sistema rápido e automático para que a integração possa ser compilada e os testes todos executados sem muita perda de tempo. Algumas equipes deixam uma máquina separada para integração, isto ajuda a tornar o processo seqüencial, evitando conflitos.

A habilidade de integrar o sistema a qualquer momento corrobora a prática de releases pequenos. Sempre existe uma cópia do sistema com todas as últimas funcionalidades que foram implementadas 
e esta cópia funciona e pode ser entregue ao cliente se necessário.

Ao integrar recebemos feedback sobre as mudanças que estamos incorporando ao código. Percebemos se uma refatoração teve implicações no trabalho de outros se, ao rodar testes depois da integração, alguma coisa quebrar. Quando modificamos algo, devido a propriedade coletiva do código, se quebramos alguma coisa distante deixa de funcionar no sistema iremos ficar sabendo disso no momento da integração. Destas maneiras, a integração contínua apóia as práticas de refatoração, propriedade coletiva do código e testes, evitando que elas introduzam erros no sistema e que estes passem desapercebidos por muito tempo.

O design simples, mantido através de refatorações, apóia a integração contínua, pois fica mais fácil integrar novas mudanças e essas mudanças se mantém simples e pequenas. Programação pareada também enfatiza esta prática ao diminuir consideravelmente a quantidade de código que precisa ser integrado.

\subsubsection{Ritmo sustentável}

Ritmo sustentável é uma das práticas que encontram mais resistência por parte de gerentes, talvez por ser inicialmente chamada de "semana de 40 horas". O objetivo desta prática é evidenciar o fato de que não adianta desgastar sua equipe com trabalhos em hora-extra, pois a produtividade irá cair inevitavelmente. Seguindo um ritmo sustentável de trabalho, toda equipe estará bem disposta e motivada para trabalhar de maneira mais produtiva.

Ao mudar o nome desta prática Kent Beck atenta ao fato que não devemos exigir exatamente 40 horas de trabalho semanais, mesmo porque cada indivíduo tem um ritmo de trabalho diferente. O importante é manter todos descansados para evitar erros relacionados ao estresse e à sobrecarga. Existe a possibilidade da equipe trabalhar horas extras quando necessário, desde que isso não se torne rotina e que a equipe tenha a oportunidade de descansar após a época de sobrecarga. Estar descansado implica em mais concentração e produtividade.

Esta prática apóia a refatoração, pois diminui a probabilidade de erros, dando mais tranqüilidade e coragem aos programadores. Corrobora também a prática de programação pareada, diminuindo a chance de brigas entre membros dos pares devidas a sobrecarga e estresse. Diminui também a probabilidade de conflitos entre a equipe toda, facilitando a propriedade coletiva do código.

O jogo do planejamento enfatiza esta prática, garantindo que a equipe tem uma quantidade razoável de trabalho a realizar e que ela poderá ser realizada no tempo disponível. Se algum problema ocorrer, replanejar é sempre possível, evitando assim a necessidade recorrente de trabalhar horas extras. Aliada à prática de testes automatizados, reduzimos também a freqüência de surpresas ou dificuldades inesperadas e aumentamos a chance de conseguir manter um ritmo sustentável como planejado.

A própria prática do ritmo sustentável se apóia, por garantir que todos estão programando na 
melhor velocidade possível, mantendo o nível de produtividade e qualidade aceitáveis.

\subsubsection{Cliente sempre presente}

Em XP, comunicação é essencial. Para melhorar a qualidade da comunicação entre os desenvolvedores e o cliente existe a prática do cliente sempre presente. Um cliente real, ou seja, alguém que conhece as necessidades daqueles que irão utilizar o sistema que está sendo construído, deve estar fisicamente junto da equipe de desenvolvedores. Desta maneira, ele poderá esclarecer dúvidas, especificar detalhes de histórias que estão sendo implementadas e, até mesmo, repensar o escopo de um release do projeto.

Esta também é uma prática difícil de adotar, principalmente pela relutância de gerentes em ceder um funcionário para, além de executar o seu trabalho, acompanhar o desenvolvimento. Porém, a prática agrega muitas vantagens ao desenvolvimento, fazendo com que o sistema entregue seja de fato valioso para a organização e diminuindo muito os custos de tempo necessário para detalhar funcionalidades requeridas no programa.

Ao exigir a presença física do cliente, XP valoriza a comunicação. A maior parte das dúvidas que surgem durante o desenvolvimento podem ser respondidas imediatamente e através de comunicação verbal, deixando pouco espaço para que os desenvolvedores tenham que adivinhar o que o cliente realmente queria. Além disso, o cliente pode dar feedback instantâneo de histórias que estão sendo implementadas, podendo inclusive entender melhor o requisito que o seu sistema tem de fato. A prática elimina a necessidade de retrabalho que é freqüente quando desenvolvedores tomam decisões equivocadas de pequena escala, delegando esta responsabilidade a um representante legitimo do negócio.

Além de responder dúvidas e, como já vimos, participar ativamente do jogo do planejamento, o papel do cliente é também escrever testes funcionais automatizados. Para isso, o cliente deve primeiro especificar os testes das histórias que compõem um release, e então parear com algum desenvolvedor para codificá-los. Estes testes poderão ser executados de maneira automática por todos, complementando desta maneira a prática de testes automatizados.

Esta prática complementa também o jogo do planejamento, adiando a especificação detalhada de histórias para o melhor momento possível, que é quando elas estão sendo codificadas. Além disso, ao estar presente, o cliente tem acesso direto a informações sobre o andamento do projeto, podendo acompanhar todas as métricas organizadas pelo acompanhador e ser informado no momento certo se há necessidade de renegociar o escopo de um release. Ainda mais, ao estar presente, o cliente contribui para criação de uma metáfora consistente, apoiando esta prática também.

\subsubsection{Padrão de codificação}

Esta última prática determina que no início do projeto, todos desenvolvedores da equipe concordem sobre um padrão de estilo a ser utilizado no código fonte do sistema. Esta prática facilita 
a leitura do código por qualquer desenvolvedor e garante uma nomenclatura consistente em todo o sistema, independente do programador que codificou determinada parte. Com o passar do tempo, fica praticamente impossível dizer quem da equipe escreveu determinado pedaço de código, pois todos usam o mesmo estilo. Este padrão deve priorizar a comunicação, ser simples e minimizar a quantidade de trabalho necessário para adotá-lo. Além disso, ele deve ser aceito de maneira voluntária por toda a equipe.

Esta prática complementa muito bem a propriedade coletiva do código pois é fácil e natural mudar o código dos outros se ele é similar ao código que você escreve, não importa quem o criou originalmente. Além disso, não existem brigas na equipe sobre qual estilo adotar, diminuindo também a possibilidade de atritos durante a programação pareada.

Padrão de codificação enfatiza a prática de refatoração pois facilita a alteração do código: refatorar não vai implicar em mudar também a formatação do código. Programação pareada também é mais fácil quando existe um padrão, pois o par não precisa discutir questões de formatação e pode se concentrar no problema a ser resolvido.

A prática da metáfora corrobora o padrão de codificação, pois além de usar as mesmas regras para criação de nomes de classes e métodos, a metáfora garante uma consistência de linguagem que facilita o entendimento do sistema e faz parte do padrão.

\subsection{Papéis}

XP define quatro papéis principais: os programadores, o cliente, o treinador e o acompanhador. Na primeira versão, Beck [Bec99] também cita 3 papéis secundários: testador, consultor e o "chefão". Ao discutir as práticas, quase esgotamos as atividades e interações entre os programadores e o cliente. O papel de testador é absorvido pelos programadores, especialmente o programador que deve parear com o cliente para escrever testes funcionais. O consultor é um papel externo, que surge quando há necessidade de experiência técnica, ele trabalha exatamente como um programador, pareando com o resto da equipe para disseminar seu conhecimento. O "chefão" tem o papel de patrocinar a equipe que está adotando XP e dar respaldo a ela dentro da organização. Resta explicitar melhor as atividades relacionadas aos papéis do treinador e do acompanhador, que faremos a seguir.

\subsubsection{Treinador}

O treinador é uma pessoa com perspectiva independente, alinhado com os valores da organização, mas principalmente alinhado com os valores de XP. É experiente tanto na aplicação da metodologia e nas suas práticas, quanto em tecnologias. Deve ser um bom programador e conhecer práticas alternativas e outras metodologias ágeis, atuando para garantir a qualidade do trabalho. Este papel deve ser exercido por uma pessoa madura, que respeita a equipe e é respeitado por ela, sabendo falar quando necessário, mas principalmente sabendo ouvir.

O principal papel do treinador é ajudar a equipe a usar e entender XP durante o início do processo 
de adoção da metodologia por uma organização. É uma metodologia que requer alta disciplina, portanto o treinador reforça esta disciplina, mantendo a equipe no processo correto. Não é recomendável adotar XP sem a ajuda de um treinador experiente. Ao ajudar na implantação de XP, ele deve sugerir caminhos para adoção de práticas e estar atento ao andamento da equipe. Por ser experiente, ele também atua como mentor de tecnologias e práticas como testes, refatoração e integração contínua. Sem um treinador de atitude pró-ativa que assume a liderança, a equipe fica a deriva na transição para Programação eXtrema. Conseqüentemente a qualidade do trabalho diminui com o tempo e o risco de reverter a velhos hábitos e padrões aumenta.

O trabalho do treinador é presencial e deve ser feito, se possível, de maneira indireta. É mais importante fazer com que a equipe perceba um erro e descubra como resolvê-lo sozinha, do que resolver o erro. Seu papel é fazer com que as pessoas percebam o erro, não explicitá-lo. Um exemplo seria criar um teste que evidencia uma necessidade de simplificação do design em vez de dizer que o mesmo precisa ser simplificado. O treinador dá liberdade para a equipe explorar, mas também avisa quando estão no caminho errado.

Durante seu dia-a-dia, o treinador exerce diversas atividades. Ele monitora o processo, chamando atenção da equipe quando as práticas não estão sendo seguidas. Ele reforça o processo, chamando a atenção de pessoas que não estão fazendo o seu melhor, ou até mesmo indo contra as práticas e, eventualmente, sugere que estas pessoas deixem a equipe. Ele muda o processo, adaptando práticas ao contexto local, ou até sugerindo novas práticas. Ele atua como mentor, pareando na programação em tarefas mais complexas ou em sessões de design. Ele também cuida da atmosfera relaxada da equipe e é responsável por garantir que o ritmo esteja sustentável.

Além de exercer estas tarefas, o treinador está atento a problemas que podem ocorrer. Se a velocidade de uma equipe cair, ele deve procurar a causa, reforçando práticas que podem retomar o ritmo, ou chamando o cliente para reduzir o escopo da iteração. Se o código está feio ou apresenta muitas duplicações, ele deve reforçar a prática de refatoração. Se a qualidade do software cair, ele deve reforçar a prática de testes.

O papel do treinador diminui de importância com o passar do tempo. Os próprios programadores, ao adquirir experiência com a metodologia, assumem o papel de monitorar o processo. Quando isso acontecer, o treinador pode deixar a equipe para que ela continue de maneira independente.

\subsubsection{Acompanhador}

O acompanhador é a consciência da equipe, ajudando o time a entender o progresso do desenvolvimento. Seu papel não é de dedicação exclusiva, exigindo pouco tempo de trabalho durante o dia-a-dia. Consiste em coletar informações para criar métricas do andamento do processo. Uma das principais atividades é coletar feedback das estimativas dos programadores, desta maneira medindo a velocidade do desenvolvimento.

Com estas informações, o acompanhador consegue dizer se a equipe vai conseguir terminar uma 
iteração entregando todas histórias prometidas, ou se é preciso renegociar o escopo com o cliente. Algumas informações básicas sobre o progresso do projeto são relativas ao planejamento do release, como o número de histórias prometidas e as que já foram implementadas. O planejamento da iteração pode ser acompanhado através do número de tarefas selecionados para iteração em comparação as tarefas que já foram completas. O progresso de uma iteração pode ser medido observando o número de testes de aceitação criados e subtraindo os que foram bem-sucedidos.

Além disso, métricas podem surgir para analisar informações que são valiosas para a equipe, que preocupam a equipe, ou que a equipe quer que outros saibam. É importante ter métricas negativas, principalmente quando precisamos evidenciar comportamentos problemáticos, que se repetem e que podem melhorar, mas é importante também ter métricas positivas. Ron Jeffries [Jef04] sugere uma série de métricas e diferentes maneiras de visualizá-las, enfatizando que as métricas e respectivas medidas precisam estar visíveis para todos envolvidos, em gráficos grandes e feitos à mão, valorizando a comunicação. É importante criar um espaço informativo, onde estes radiadores de informação mostrem medições sobre o andamento do projeto de maneira objetiva. Estas informações são efetivamente o histórico do projeto. A Figura 2.2 é um exemplo de um gráfico que mostra uma representação de métrica sobre o andamento de um projeto:

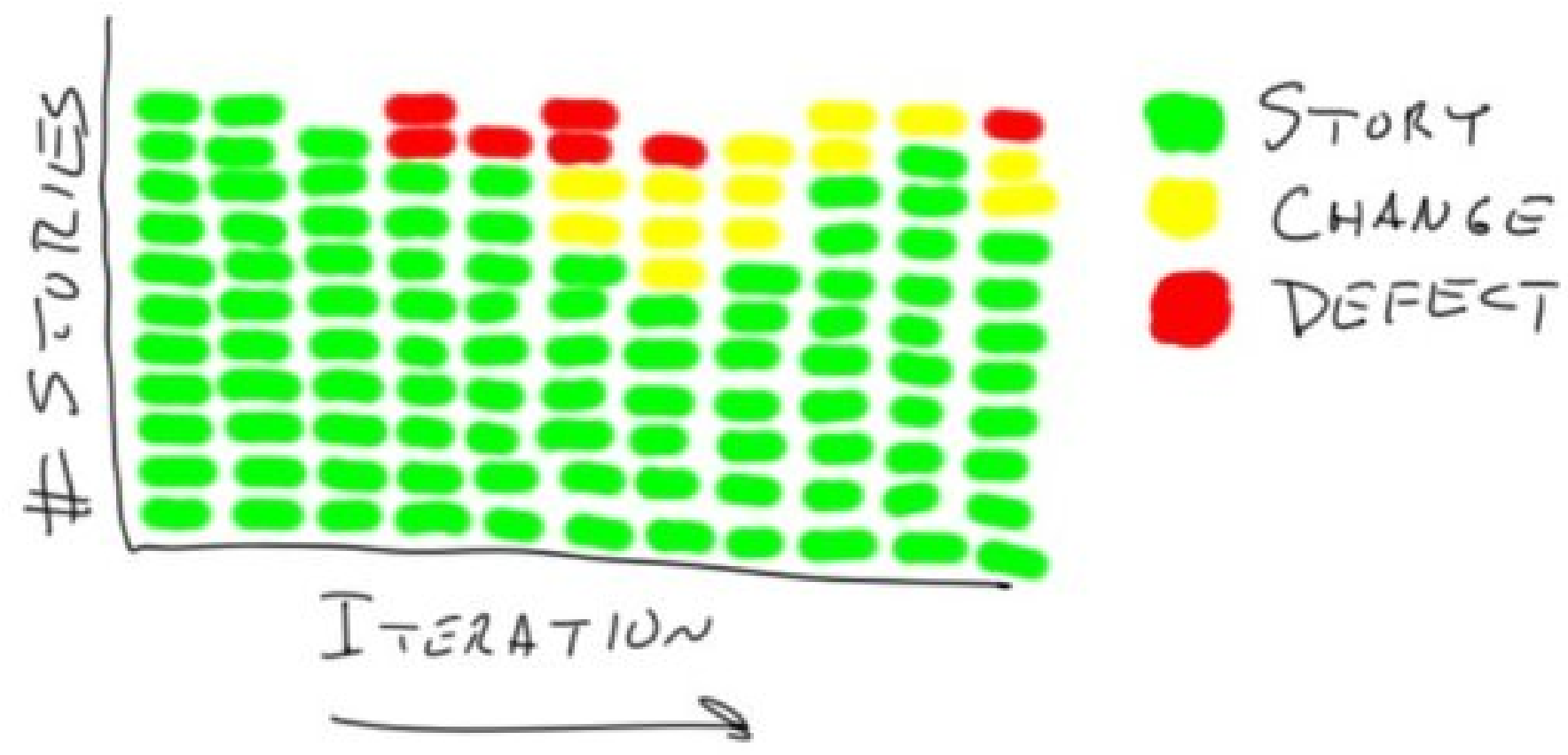

Figura 2.2: Cartaz com representação de métrica que ilustra o andamento do projeto (cada coluna é uma iteração). Histórias implementadas estão em verde, mudanças em histórias em amarelo e correção de defeitos em vermelho, tudo isso realizado em cada iteração. (JEFFRIES, 2004)

Durante o seu trabalho, o acompanhador pode usar diferentes suportes para suas métricas, como cartazes nas paredes, desenhos em quadros brancos, ou até mesmo planilhas. Dialogar com o trei- 
nador é valioso, pois ele pode sugerir métricas que irão evidenciar para a equipe possíveis problemas ou progressos importantes. Ao coletar medições relativas às métricas adotadas, o acompanhador deve tentar não incomodar a equipe. Além disso, ele deve aposentar métricas quando elas tiverem surtido o efeito necessário. Isso diminui a quantidade de informação visual no espaço, melhorando a comunicação e mantendo em evidência aquilo que, no momento, é o mais importante para a equipe.

\subsection{Adaptações e a adoção de novas práticas}

Ao adotar XP, uma organização deve estar ciente de que o processo de chegar ao amadurecimento da metodologia é relativamente lento e trabalhoso. XP é uma metodologia que requer muita disciplina e que requer mudança social. Adotar seus valores leva tempo e implantar todas suas práticas também. Durante este processo, é importante adaptar XP ao contexto local, possivelmente refatorando algumas práticas, ou criando novas práticas, ou até mesmo pegando-as emprestadas de outros métodos ágeis. A seguir, iremos citar algumas possibilidades que tem nos ajudado a implantar XP em diferentes organizações.

Uma das práticas de Scrum [SB01] pode incrementar XP de maneira bem eficiente; é a prática de fazer encontros diários para micro-planejamento e comunicação da equipe. Estes encontros são chamados de stand-up meetings ou papo-em-pé na nossa tradução, por serem feitos com a equipe toda em pé, afim de não alongar as discussões. Nestes encontros, a equipe descreve no que tem trabalhado, o que está funcionando bem para eles e dificuldades com as quais possam precisar de ajuda. Temos adotado essa prática pois ela garante que o encontro mantém-se curto e maximiza a comunicação efetiva, seguindo o princípio de respeito mútuo. Além disso, esta prática ajuda a evidenciar as dificuldades individuais e compartilhar soluções descobertas pelos membros da equipe [SBG07].

O uso de ferramentas que auxiliam no processo pode ser determinante ao diminuir a curva de aprendizado de certas práticas. Em nossa experiência, um ambiente de desenvolvimento como o Eclipse ajuda no processo de implantação de XP ao auxiliar diretamente diversas práticas. Neste ambiente, padrões de codificação podem ser impostos diretamente no software e, ainda melhor, eles podem ser criados em conjunto no início de um projeto e compartilhados para todos desenvolvedores de maneira simples. Além disso, as facilidades de correção de sintaxe e até mesmo de autocomplemento de nomes de classes, variáveis e métodos fazem com que o Eclipse possa ser considerado um ajudante extra para a dupla que está programando. Erros de sintaxe que escapam à atenção do chapa não passarão despercebidos por esta ferramenta. Quando ninguém da dupla consegue lembrar a assinatura de um método, a ferramenta faz isso para eles de maneira simples e veloz. A integração de ferramentas de testes ao ambiente torna o aprendizado e adoção da prática de testes muito mais fácil. Finalmente, as ferramentas de refatoração são indispensáveis para automatizar processos que poderiam ser complicados e difíceis se executados manualmente.

Uma das adaptações mais comuns em projetos que adotam XP é relativa à prática do cliente sempre presente, justamente por esta prática exigir uma maior mudança cultural. Nesta adaptação, 
introduzimos um novo papel na equipe, o Cliente Proxy, devido à impossibilidade de se ter um cliente real sempre presente [WBA02, Wue02, NH04]. O Cliente Proxy pode ser um programador ou um gerente que se responsabiliza por fazer a intermediação entre a equipe de desenvolvedores e o cliente real; o papel pode ser alternado por diferentes pessoas. O importante é que o Cliente Proxy esteja presente fisicamente e atue como deve atuar o cliente em condições ideais. Ele responde a perguntas dos desenvolvedores, especifica melhor histórias e toma decisões de pequena escala. Esta prática implica que o Cliente Proxy deve tentar manter contato próximo com o cliente real, reunindose presencialmente com ele sempre que possível, mantendo conversas por voz ou, em último caso, utilizando correio eletrônico. O Cliente Proxy deve sempre validar suas decisões com o cliente real e, caso o cliente real tome uma decisão diferente da que foi tomada pelo Cliente Proxy, este deve imediatamente comunicar à equipe que mudou de idéia. A prática é eficaz ao permitir a comunicação com o cliente e disponibilizar um intermediário efetivo para que a equipe possa trabalhar de acordo com aquilo que a metodologia propõe inicialmente.

A prática de Retrospectivas [SCU97, SKKL ${ }^{+}$04, RD03], ou "Oficinas de Reflexão" como define Cockburn [Coc02], é anterior às metodologias ágeis e pode agregar muito valor ao processo de implantação de XP em uma organização. Ela consiste em uma atividade que pode ocorrer semanalmente ou mensalmente, após o término de uma iteração ou um release, na qual todos envolvidos no processo param para pensar no próprio processo. Durante esta atividade, toda a equipe deve listar de algum modo os acontecimentos bons relativos à maneira como o trabalho foi efetuado e que não queremos esquecer e também aquilo que aconteceu e não foi muito bom (evitamos falar em acontecimentos ruins) e queremos melhorar. É importante ressaltar duas regras desta atividade que existem para minimizar conflitos: não culpar e não citar nomes. Após algum tempo durante o qual todos podem anotar suas impressões, o treinador conduz o processo e lista todos os acontecimentos bons, agrupando eventuais duplicatas. Esta lista é então disponibilizada no espaço informativo da equipe.

Acontecimentos que não foram tão bons também são listadas e agrupados, porém após esta listagem, a equipe deve de alguma maneira determinar quais são os três itens nesta lista que devem ser corrigidos com maior prioridade. Isto pode acontecer em uma votação, ou cada membro da equipe pode distribuir um número fixo de pontos entre os itens da lista. Ao determinar os três itens mais prioritárias, o treinador então conduz a equipe a listar, para cada um deles, ações concretas que podem ser tomadas para evitar que os problemas recorram. Esta lista de ações concretas deve ser um acordo da equipe e deverá ser aplicada durante a próxima iteração.

Esta prática é importante para refletir sobre a adoção da metodologia, descobrir pontos que podem ser melhorados e chegar a um acordo de maneiras como esta melhoria deve ser conduzida [SBG07]. As retrospectivas são importantes para evidenciar tudo de bom que aconteceu e também para gerar uma oportunidade na qual insatisfações poderão ser discutidas e erros corrigidos com a ajuda de todos. 


\subsection{A nova versão de XP}

No início, a dificuldade de implantar XP em uma organização era justamente o alto acoplamento entre as práticas e o fato de que elas não poderiam ser aplicadas individualmente de maneira segura. Grande parte da resistência à metodologia provinha deste aspecto. Além disso, a comunidade muitas vezes dizia que críticas de quem não fazia XP 100\% não eram válidas, pois os defeitos apontados eram devidos à não adesão completa a XP.

Após cinco anos de experiência e feedback, Beck reescreveu a metodologia de maneira mais positiva e inclusiva, mudando seu discurso [BA04]. Enquanto no primeiro livro Beck parecia tentar convencer as pessoas a programar de sua maneira, no segundo livro ele tenta explicar as razões que tornam sua maneira de programar mais eficiente e deixa a escolha de adotar ou não cada uma das práticas aos indivíduos. Além disso, ele discorre sobre como é este processo de adoção e provê maneiras mais fáceis de implantar a metodologia incrementalmente.

A evidência desta mudança no teor do discurso é o novo valor, respeito, agregado aos outros quatro: comunicação, simplicidade, coragem e feedback. Valorizar o respeito significa valorizar a relação entre membros da equipe e, também, a relação de cada membro com o projeto e sua instituição. Beck ainda explicita que a instituição pode ter outros valores e que o importante é alinhar a equipe com todos estes valores.

Nesta versão, mais importância é dada aos princípios, um instrumento importante que inclusive pode ser utilizado na adaptação de práticas ao contexto local e até mesmo na criação de novas práticas. Os princípios funcionam como guias, específicos ao domínio da programação, para localizar práticas concretas em harmonia com os valores abstratos.

Todas as doze práticas da primeira edição estão contempladas nesta segunda. Porém elas foram refatoradas para tornar mais simples a adoção incremental da metodologia e para explicitar detalhes que acabavam perdidos em meio à complexidade de algumas práticas anteriores. Beck deixa mais claro que as práticas são objetivos e, no dia-a-dia, nossa execução de uma determinada prática pode não ser exatamente como deveria, pois uma prática depende da situação e do contexto no qual está sendo aplicada. As práticas funcionam: foram validadas através do uso em outros projetos e funcionam melhor quando aplicadas em conjunto. Porém nesta versão as práticas foram divididas em dois grupos: as práticas primárias e as práticas corolário. As práticas primárias são independentes, podem ser aplicadas de maneira segura individualmente e provêm melhorias imediatas ao processo de desenvolvimento da equipe. As práticas corolário são mais difíceis de dominar se as primárias não forem aplicadas e são interdependentes. Beck ressalta que a interação entre as diferentes práticas amplia seus efeitos.

A seguir iremos detalhar os princípios que formam a base da metodologia, as práticas primárias e corolário, a nova abordagem sobre os papéis exercidos pelas pessoas em XP e, finalmente, as mudanças e evoluções em relação à primeira abordagem. 


\subsubsection{Princípios}

Os princípios são ferramentas intelectuais para traduzir valores abstratos em práticas concretas pelas quais uma equipe pode se responsabilizar e cuja adoção pode ser medida.

Humanidade reconhece que são pessoas com necessidades humanas que desenvolvem software. Destas necessidades, algumas podem ser satisfeitas no trabalho. São elas segurança, crescimento, identidade com o grupo, realização, intimidade e privacidade. Este princípio se concretiza na prática de trabalho energizado. Com tempo para se dedicar a satisfazer suas outras necessidades fora do trabalho, os seres humanos podem voltar com energia para se dedicar ao trabalho. Um dos desafios proposto por este princípio é balancear as necessidades individuais com as da equipe.

Economia busca garantir valor para o negócio. Ao economizar pensamos sobre o valor do dinheiro ao longo do tempo e como melhor empregá-lo. É importante receber o mais cedo possível e gastar o mais tarde possível. É importante também refletir sobre o valor de opções que podemos tomar pela equipe e pelo sistema, percebendo que a habilidade de poder mudar de idéia no futuro deve guiar nossas decisões. Este princípio é evidenciado nas práticas de design incremental e pague-pelouso e também na priorização e estimativa de histórias, garantindo que uma equipe XP não invista em flexibilidade especulativa.

Benefício Mútuo é o princípio mais importante e difícil de seguir. Um exemplo de como ele se concretiza é a ênfase dada em XP a testes, refatorações e a metáfora no lugar de extensa documentação escrita. A documentação não traz benefício para os programadores no ato de sua criação, só à organização em um possível futuro. Enquanto investir em testes, refatorações e na construção de uma metáfora trazem benefícios imediatos aos programadores, ao sistema, ao cliente e à organização.

Auto-semelhança diz que se deve copiar estruturas e processos existentes para resolver problemas em diferentes contextos ou escalas. É o caso do ritmo similar que observa-se nas práticas do ciclo de estação, ciclo semanal e nas atividades diárias de programação. Observamos que primeiro criamos testes e depois trabalhamos para que eles funcionem. No ciclo mensal, escrevemos testes de aceitação, que no final devem todos passar para validarmos um release. Nas atividades diárias escrevemos testes de unidade para validar tarefas que devem ser codificadas.

Melhoria indica que não devemos esperar a perfeição mas sim fazer o melhor que podemos hoje, para poder fazer o melhor amanhã. A prática de ciclo de estação evidencia este princípio dando à equipe a oportunidade de melhorar o plano de um release. A prática de design incremental também segue o princípio da melhoria.

Diversidade lembra que um time com pessoas diferentes apresenta mais habilidades, conhecimentos e oportunidades. A diversidade é causa de conflitos, sendo importante lidar com essa possibilidade valorizando o respeito. O princípio é evidente nas práticas do time completo e nos diferentes ciclos 
de planejamento. Pessoas com perspectivas diversas tem igual oportunidade de colaborar nestes: aquelas que pensam à longo prazo contribuindo com o ciclo de estação e as que tem perspectivas de curto prazo contribuindo com o ciclo semanal.

Reflexão implica em pensar sobre como e por que trabalhamos. Este princípio pode guiar uma equipe a adotar práticas como a retrospectiva e a realizar análises freqüentes do seu processo de adoção da metodologia. Para isso, é preciso tempo para pensar. É importante socializar com a equipe em contextos de diversão ou até em refeições. A reflexão é evidenciada nas práticas do ciclo de estação e o ciclo semanal, nas conversas de pares programando e na prática de integração contínua.

Fluxo determina que exista uma corrente contínua de atividades e que o processo deve explicitá-la. Desta maneira permiti-se que as etapas do desenvolvimento aconteçam em paralelo e não seqüencialmente como proposto em metodologias mais tradicionais. As práticas de releases freqüentes e integração contínua evidenciam isto.

Oportunidade nos leva a encarar problemas como oportunidades para mudança. Estar aberto a oportunidades de aprender e melhorar durante todo o processo é importante.

Redundância aumenta as nossas chances de sucesso, promovendo várias oportunidades de fazer a coisa certa. A redundância está presente na complementação das práticas, e nos testes de unidade automatizados: escrevemos o código fonte e, de maneira redundante, escrevemos mais código para verificar se o primeiro funciona, diminuindo a nossa probabilidade de errar.

Falha indica que pode ser bom falhar, desde que se aprenda com a experiência. Quando uma equipe não sabe para onde ir, arriscar-se a falhar pode ser o caminho mais curto para obter o sucesso. Este princípio é complementar ao valor de coragem e se evidencia na prática de abandonar código e começar de novo quando percebemos que determinado plano não poderá ser realizado.

A Qualidade não deve diminuir nunca. Este princípio diz que quanto maior a qualidade, mais fácil será realizar o trabalho. Ele complementa o princípio da humanidade ao satisfazer a necessidade de se orgulhar do trabalho feito e é evidenciado na prática de controle do escopo no planejamento.

Passos pequenos garante que iremos fazer sempre o caminho mais curto na direção correta, pois a execução de tarefas complexas em passos pequenos diminui o risco. A prática de design incremental, integração contínua, implantação incremental e implantação diária refletem este princípio.

Aceitação de Responsabilidade evidencia que só o próprio indivíduo pode se responsabilizar por suas ações. Este princípio está claro na prática de estimativas feitas pelos próprios programadores no jogo do planejamento. 


\subsubsection{Práticas primárias}

As práticas primárias são guias para se começar a adoção de Programação eXtrema em uma organização. Elas podem ser implantadas facilmente pois são seguras e devem ser introduzidas em pequenos passos, para evitar uma mudança muito rápida na cultura da organização. É importante ter tempo para que os novos hábitos sejam incorporados pela equipe. $\mathrm{O}$ uso de métricas para aumentar a consciência sobre a necessidade ou benefícios de uma prática e a avaliação da experiência, usando retrospectivas por exemplo, também é recomendado. Das práticas originais, a programação pareada e a integração contínua se mantêm sem mudanças relevantes. Além destas duas, a prática de ritmo sustentável foi renomeada novamente e agora se chama trabalho energizado, eliminando criticas à quantidade de horas que representam trabalho produtivo e sustentável. A prática de testes automatizados foi rebatizada de desenvolvimento dirigido por testes e inclui a prática de refatoração. Além disso a prática de design incremental engloba as práticas de metáfora e novamente refatoração em uma atividade diária. A seguir iremos detalhar as novas práticas.

Sentar Juntos deixa explícita a necessidade de se ter um espaço onde toda a equipe possa trabalhar junta, valorizando a comunicação e possibilitando que as pessoas possam se beneficiar de todos seus sentidos ao conversar. Ressalta-se também a necessidade de pequenos espaços privativos para respeitar o princípio de humanidade.

Time Completo lembra que a equipe precisa de pessoas com todas as habilidades e perspectivas necessárias para o sucesso do projeto. Nesta segunda versão, Beck remove a limitação de tamanho das equipes e ressalta somente dois limites naturais: equipes de 12 pessoas é o limite natural de pessoas com as quais um indivíduo pode interagir em um dia; e equipes de 150 pessoas é o limite natural para que um indivíduo se lembre de todos outros no time. Beck recomenda que se fracione problemas complexos e que estes sejam resolvidos com times que respeitem estes limites.

Espaço de trabalho informativo era uma prática implícita que ganhou destaque na segunda edição. Ela diz que qualquer observador interessado deve ser capaz de olhar para o espaço de trabalho e ter idéia do andamento do projeto em pouco tempo. O espaço informativo deve conter cartazes grandes e visíveis, que comunicam medidas coletadas pelo acompanhador. Limpeza, ordem, espaço para programação pareada e disponibilidade de água e comida garantem que o espaço informativo complemente a prática de trabalho energizado.

Histórias que antes faziam parte do jogo do planejamento, viram uma prática independente na segunda versão. Elas continuam iguais: textos simples que expressam necessidades do cliente e que são estimadas, o quanto antes, pelos programadores.

Ciclo semanal que antes era parte do jogo do planejamento, explicita as iterações que fazem parte de um release. O ciclo semanal inclui um jogo de planejamento do trabalho que deve ser efetuado em 
aproximadamente uma semana, ou seja, planeja as iterações de menor granularidade. Uma reunião no começo da semana revê o progresso de um release, comparando o que foi feito com o que tinha sido planejado na semana anterior. O cliente prioriza uma semana de histórias, que são divididas em tarefas, que por sua vez são aceitas e estimadas pelos programadores. A semana começa com a escrita de testes de aceitação da iteração e acaba com a implantação do sistema codificado. Beck reconhece que o planejamento custa tempo, mas que esse é um gasto necessário.

Ciclo de estação ( Quarterly Cycle) que antes era parte do jogo do planejamento, explicita o planejamento de um release. A avaliação de um ciclo de estação pode identificar gargalos e dependências da equipe com outras partes da organização, apresentando uma oportunidade para melhorias e reparos. Durante o planejamento deste ciclo, temas são escolhidos para a estação. Estes temas servem para agrupar histórias relacionadas, que também são criadas neste momento. O uso de temas garante que não há exagero de detalhes e que o planejamento acontece com a perspectiva do longo prazo. O enfoque do planejamento da estação é também perceber como o projeto se encaixa com o resto da organização. A estação pode ter duração variável e depende do contexto do negócio. Em muitas organizações um trimestre é uma boa medida para avaliar o progresso.

Folga reconhece que o planejamento, por melhor que tenha sido, sempre falha. Para evitar atrasos ou a necessidade de renegociação de escopo, o planejamento deve conter explicitamente espaços de folga. Isto pode acontecer tanto com a introdução de tarefas menores, que podem ser descartadas em caso de atraso, quanto com a distribuição de histórias de trabalho livre para os programadores. Se o progresso de um ciclo for bom, este tempo pode ser usado para pesquisa e para manter o trabalho energizado. Caso atrasos ocorram, a folga pode ser descartada e mais trabalho pode ser realizado para que a equipe consiga entregar as histórias que prometeu ao cliente.

Build veloz exige que o sistema deve ser compilado por completo e todos os testes devem ser executados, de maneira automática, em no máximo 10 minutos. Esta prática provê agilidade à equipe e complementa a habilidade de entregar releases pequenos. O limite de 10 minutos é somente o tempo razoável para que o par possa tomar um café durante o build, porém não é essencial. Se o build demora menos que 10 minutos, excelente, o café pode ficar para depois. Se demora mais existem duas possibilidades. A primeira é de que o build pode ser refatorado, para que não rode todos os testes de aceitação por exemplo, pois estes podem demorar muito tempo para serem executados. A segunda é de que o build é lento pois o sistema é muito complexo, e a demora pode ser um indício da necessidade de simplificá-lo.

Design incremental A prática de design simples rendeu criticas a XP que diziam que a metodologia não investia em design da aplicação. Para responder às críticas, Beck a redefine como design incremental. Esta prática implica em investimento diário no design da aplicação justificando seu fluxo contínuo ao mostrar que, se realizado próximo de ser utilizado, ele tende a ser mais eficiente e valioso. 


\subsubsection{Práticas corolário}

As práticas corolário são difíceis ou perigosas de serem implementadas sem antes serem dominadas as práticas primárias. O conselho de progredir incrementalmente em direção às práticas se mantém. A prática do cliente sempre presente foi renomeada para envolvimento real com o cliente e assume que muitas vezes um cliente direto não poderá ser colocado com a equipe. A prática de propriedade coletiva do código foi renomeada para código compartilhado e se mantém como prática corolário. A seguir iremos detalhar as novas práticas.

Implantação incremental lida com uma equipe que deve substituir um sistema legado e diz que essa substituição deve ser feita incrementalmente. O importante é manter o sistema funcionando e ter segurança na migração. É possível que, durante algum tempo, ambos o legado e o novo sistema devam funcionar em conjunto, adicionando um pouco de trabalho de comunicação extra tanto no sistema quanto com usuários, mas garantindo harmonia na migração.

Continuidade da equipe propõe que equipes eficientes continuem trabalhando juntas. Deve-se incentivar um rodízio razoável entre equipes, mas ao se concentrar na eficiência da organização como um todo, o valor de equipes que trabalhem bem juntas se torna evidente.

Redução da equipe Com o passar do tempo, a necessidade de uma equipe grande pode diminuir, principalmente se o sistema entra em um ciclo de manutenção. Se isto acontecer, mantenha a carga de trabalho constante e distribua tarefas de modo a deixar alguém ocioso; esta pessoa pode ser liberada para formar novos times. Esta prática tende a eliminar o desperdício e ajudar a organização a resolver novos problemas.

Análise da causa inicial Sempre que encontrar um defeito, elimine o defeito e sua causa, para que o mesmo tipo de erro não ocorra novamente. Esta prática define uma nova atividade: ao encontrar um defeito, um par deve primeiro escrever um teste de aceitação automatizado que evidencie o erro no nível do sistema e então escrever um teste de unidade no menor escopo possível. O par deve proceder para resolver o problema e passar nos testes. O último passo é descobrir por que o defeito surgiu e, principalmente, como ele passou despercebido. A técnica de análise da causa inicial propõe que se pergunte 5 vezes o porquê do defeito ter surgido e sugere que a causa inicial, na maioria das vezes, é um problema relacionado à equipe e que pode ser resolvido utilizando-se práticas que evitem que ele recorra.

Código e testes explicita que só o código fonte e os testes automatizados devem ser artefatos permanentes gerados por uma equipe XP. Até mesmo as histórias e cartazes devem ser descartados, pois o histórico do projeto se mantém por mecanismos sociais. A cerimônia envolvida em documentação interrompe o fluxo de valor. 
Repositório único de código complementa a prática de código compartilhado e vai além, dizendo que todo o código deve estar contido em um único repositório que não deve ter branches permanentes. O problema com múltiplos repositórios é que eles não escalam. Se o seu sistema é tão complexo que precisa de repositórios separados, isso é evidência de um problema no design.

Implantação diária é a evolução da prática de releases pequenos e é ainda mais extrema. Ela determina que o seu sistema deve ser implantado diariamente, de preferência com auxílio do build veloz. O objetivo é colocar histórias implementadas em produção toda noite, para que os usuários possam usufruir de benefícios o quanto antes. Esta prática depende de uma baixa taxa de defeitos e de um processo automático de implantação, com habilidade para implantação incremental e eventuais rollbacks em caso de falhas.

Contrato de escopo negociável determina como devem ser feitos contratos em um projeto que adota XP, fixando o tempo, custos e a qualidade, mas mantendo o escopo negociável. Desta maneira, o escopo é negociado constantemente com o cliente, possivelmente no planejamento do ciclo de estação. Assim a equipe poderá celebrar uma seqüência de contratos curtos. Vinicius Teles disponibilizou [Vin07] um modelo de contrato de escopo negociável que poder ser usado na legislação vigente no Brasil.

Pague pelo uso também aborda o lado de negócios de um projeto XP, sugerindo que o cliente pague por toda vez que for usar o sistema (trazendo à tona o debate sobre "arquiteturas orientadas a serviços" que está em voga na indústria atualmente). Esta prática valoriza o dinheiro como feedback mais importante e provê ao cliente possibilidades de prever custos.

\subsubsection{Papéis}

Nesta nova versão, Beck inclui todos as funções que tipicamente se encontram em uma organização que desenvolve software e explicita quais são os papéis que cada uma pode assumir para colaborar com uma equipe XP. A diversidade de papéis traz benefício à prática de time completo. Cada parte no grupo deve entender seu papel no todo e a interação entre as pessoas deve seguir os princípios de fluxo e benefício mútuo. Uma pessoa pode assumir mais de um papel e os papéis podem ser revezados entre as pessoas.

O nível mais alto da organização conta com Gerentes de Produto que colaboram tanto no papel de clientes proxy quanto com o planejamento. Eles escrevem e ajudam a priorizar histórias. Escolhem temas para o planejamento de estação e representam as necessidades dos clientes reais. Estes são auxiliados por Gerentes de Projeto que facilitam a comunicação dentro do time, coordenam a comunicação com o cliente, marcam progresso e mantém os planos da equipe sincronizados com a realidade da organização. Gerentes de Recursos Humanos trabalham em contratações e revisões, dando ênfase ao trabalho em grupo e habilidades sociais de novos contratados para garantir que junta a equipe funcione bem. Os gerentes devem atuar conectando pessoas e não como gargalos. 
Finalmente, Executivos articulam e mantém objetivos de larga escala, monitoram o andamento do projeto e incentivam e facilitam melhorias dentro da equipe; são essenciais para criar um ambiente de apoio à equipe XP dentro da organização.

Os Usuários, se acessíveis, são importantes para ajudar a escrever e escolher histórias e tomar decisões no papel de clientes proxy durante o desenvolvimento, atentos ao fato de que representam uma comunidade maior. Eles se relacionam com Projetistas de interface, que devem ajudar na escolha da metáfora do sistema, ajudar o cliente ou cliente proxy a escrever histórias e avaliar o sistema entregue para priorizar os próximos passos. Ambos se relacionam ainda com Escritores Técnicos que provêm feedback de funcionalidades implementadas, criando uma relação próxima com os reais usuários de um sistema. Os escritores técnicos produzem manuais e tutoriais e verificam se estes documentos estão sendo utilizados. Também ajudam a escolher histórias no planejamento.

Programadores guiam o processo de desenvolvimento, estimando histórias e tarefas, escrevendo testes e código, executando o build automático, melhorando o design gradualmente e praticando programação pareada. Eles são auxiliados por Arquitetos de Software que procuram oportunidades de executar refatorações em larga escala, escrevem testes para estressar a arquitetura, implementam histórias investindo em design incremental, direcionam a evolução da arquitetura e particionam o sistema para simplificá-lo. Finalmente, os Testadores ajudam o cliente a escolher e escrever testes de aceitação, também ensinando outros programadores técnicas de testes e sempre concentrando-se no que deve acontecer quando algo der errado.

É importante notar que os papéis não são fixos e que cada um deve contribuir com tudo que pode para a equipe.

\subsubsection{Mudanças e evoluções}

Alguns outros aspectos de XP também mudaram na nova versão. Em particular o planejamento, que agora sugere estimativas em tempo real, facilitando o processo que antes usava pontos. Quanto aos testes, não se exige mais que sejam realizados antes de codificar, desde que sejam realizados o quanto antes.

Uma das grandes mudanças foi assumir que XP escala para times maiores, quando a primeira versão restringia o número de desenvolvedores. Aplicar métodos ágeis em grande escala foi um tópico de pesquisa explorado [Cro04]. XP também funciona para equipes distribuídas, com as devidas adaptações das práticas.

Além disso, na nova versão a implantação da metodologia ficou mais clara como um processo incremental adaptado ao contexto local.

A Figura 2.3 mostra como as práticas evoluíram da primeira para a segunda versão de XP:

A cor da fonte indica se a prática é da primeira versão (em preto), e na segunda versão se é primária (em azul) ou corolário (em verde). Podemos observar que as práticas que foram mantidas 

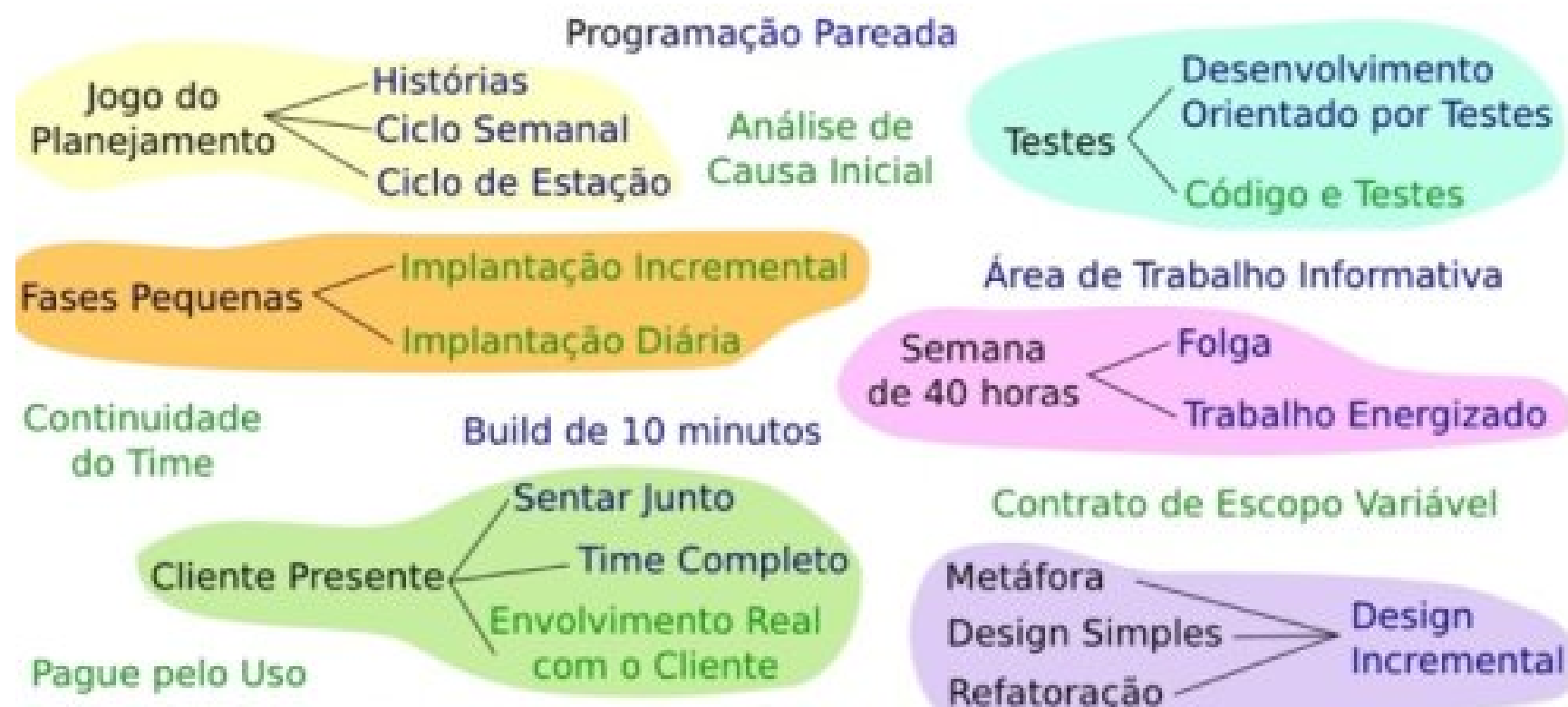

Área de Trabalho Informativa
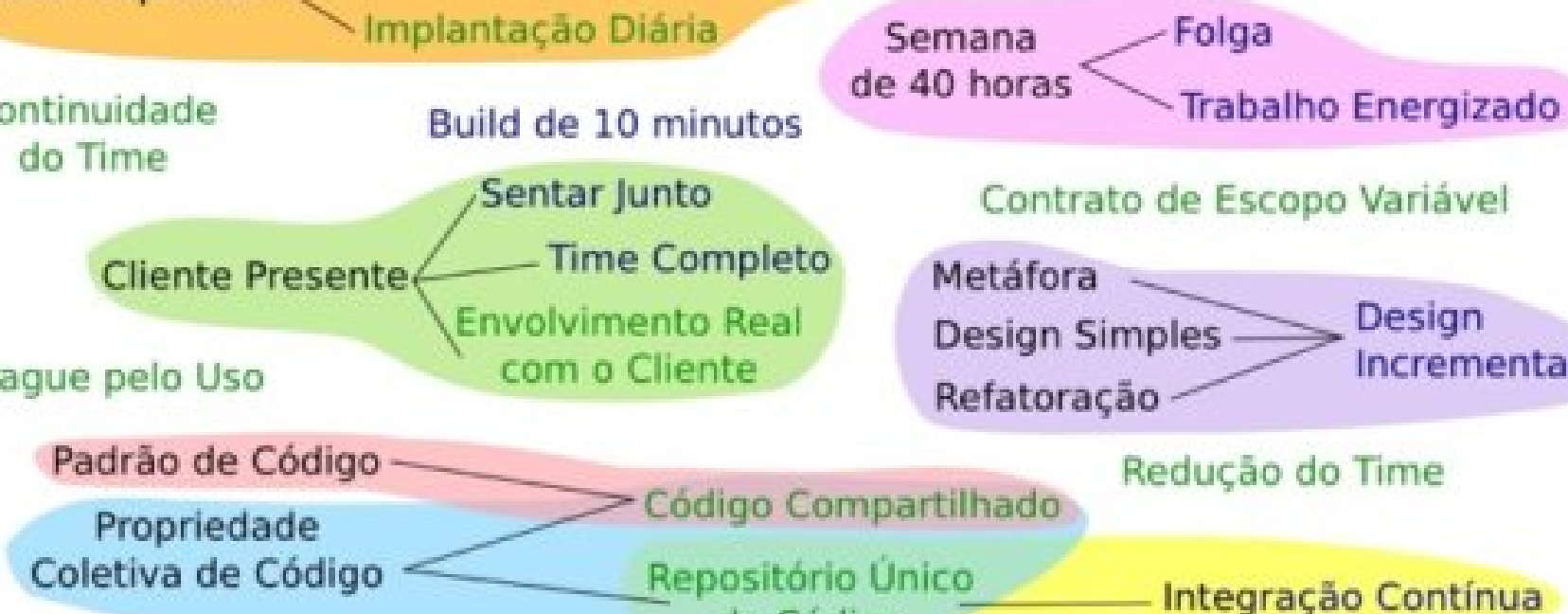

de Código

Contrato de Escopo Variável

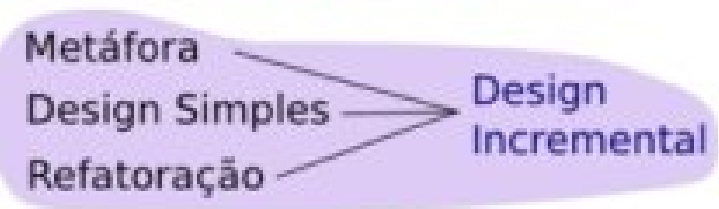

Reduçăo do Time Integração Contínua

Figura 2.3: A evolução das práticas de XP da primeira para segunda versão

entre versões se tornaram todas práticas primárias (em degradê do preto ao azul). Em grupos de cores, podemos ver como as práticas da primeira versão foram repensadas e estão compensadas nas práticas da segunda versão. 


\section{Capítulo 3}

\section{Experiências com o ensino de XP}

Como já vimos, existem muitos relatos de aplicações bem sucedidas de XP [Pel00,Lit00, DMM02, SIC01, FH03, Bos03b, How03, LWC04a, Ant04, Jac04]. Estes casos porém não se aprofundam nas questões relevantes ao nosso trabalho: refletir sobre o ensino de XP e oferecer sugestões de como melhorá-lo. Também vimos que o ensino de algumas práticas, em particular aquelas consideradas primárias na segunda versão (como testes, refatoração, programação pareada e integração contínua), já foi bem explorado. Porém, a sugestão mais freqüente é de como ensinar essas práticas de maneira isolada.

Vimos que o valor da Programação eXtrema está justamente na sinergia entre as diversas práticas portanto defendemos que a melhor maneira de ensiná-la é apresentando o todo [Ave04] de maneira prática [JST01]. Mesmo assim, existem diversas abordagens que podem ser utilizadas ao encarar o desafio de ensinar XP: palestras, jogos, cursos teóricos, workshops rápidos de um ou dois dias, cursos de média duração e cursos mais longos.

Palestras, jogos e cursos teóricos são uma boa opção para divulgar informação sobre a metodologia. Além disso são úteis e eficientes no ensino de práticas isoladas. Os cursos médios normalmente têm duração de poucas semanas e dão enfoque a atividades práticas. Esses, em conjunto com palestras, jogos, cursos teóricos e workshops, podem ser oferecidos em uma variedade de contextos. Já os cursos mais longos deverão ser aplicados levando em conta o contexto no qual irão acontecer. Na academia, podem fazer parte do currículo de ensino de computação, com duração mínima de um semestre e com o desenvolvimento de aplicações reais. Em outros contextos como na indústria ou governo, podem acontecer como consultorias e mentoring, o termo utilizado em empresas para especialistas que atuam como tutores de uma equipe.

Estas diferentes modalidades de ensino nos levam a refletir sobre a diferença entre ensinar e aplicar um método e ensinar uma metodologia. Obviamente, o objetivo final do educador deve influenciá-lo na escolha das diversas opções. Palestras, jogos e cursos mais curtos bastam se o objetivo é ensinar XP como método, apresentando uma receita relativamente fechada que poderá ser aplicada por completo, ou não, de acordo com a necessidade e vontade dos alunos após a experiência. Já se pretendemos qualificar um grupo ou organização com ferramentas e técnicas para que possam evoluir e adaptar o 
seu uso do método de maneira autônoma, devemos ter ciência de que estamos de fato ensinando XP como metodologia. Nesse caso, somente experiências mais longas e práticas serão eficazes.

Neste capítulo, apresentaremos uma síntese das experiências de ensino de XP em diferentes contextos, começando com evidências na literatura e seguindo com nossos estudos de caso. No próximo capítulo, refletiremos sobre essas experiências.

\subsection{Trabalhos relacionados na Academia}

Atualmente, podemos observar que a maioria dos cursos de graduação em Ciência da Computação no Brasil e no exterior são baseados em métodos convencionais que tem enfoque em ferramentas, documentação, contratos e a elaboração e cumprimento de planos. Engenharia de Software, que é matéria obrigatória do currículo, têm o objetivo de preparar alunos para o mercado de trabalho e para projetos de maior escala e complexidade. Nessa tentativa, a disciplina normalmente adota o modelo em cascata e o aplica em projetos de pequenos grupos. Seu maior enfoque é familiarizar alunos com a documentação que precisa ser gerada e as etapas de processos tradicionais, não criar software complexo e de qualidade.

Em 2004, uma discussão no Technical Symposium on Computer Science Education da ACM, intitulada "Teaching software development methods: The case of Extreme Programming", trouxe à tona o tópico de gradualmente introduzir algumas das práticas de XP no currículo $\left[\mathrm{HBC}^{+} 04\right]$. Esta iniciativa é válida e importante, tendo em vista a quantidade de publicações que relatam o ensino da metodologia na academia.

Em uma das primeiras experiências acadêmicas com XP, Wilson [Wil01] apresenta um projeto onde 20 alunos do quarto ano da graduação melhoraram um protótipo de IDE Java enquanto ele atuava como treinador e cliente. O curso durou um semestre e contava com sessões semanais de programação com duração de 3 horas e um Wiki para suporte. A programação pareada foi adotada, mas testes e refatorações podiam ser efetuados individulamente. A equipe não contava com um laboratório dedicado. As práticas de metáfora e cliente sempre presente não foram adotadas. A prática de testes teve resistência dos alunos no início, mas foi bem incorporada no final do curso.

Além deste caso, algumas experiências utilizando poucas práticas de XP tiverem sucesso relativo. Astrachan et al. [ADW01] relatam um curso universitário onde poucas práticas foram adotadas no desenvolvimento de projetos triviais. O curso durou 3 semanas e meia e teve a participação de 180 alunos do quarto ano da graduação. Programação pareada era usada entre o instrutor e todos os alunos ao mesmo tempo. Refatoração e releases pequenos foram as outras práticas adotadas. Lappo [Lap02] ensinou XP a um grupo de estudantes de mestrado, atuando como treinador e cliente. Eles produziram, em regime de dedicação integral, uma aplicação Web de gestão de recursos usando Java. Durante 12 semanas trabalharam em duas sessões de 3 horas diárias. Segundo sua avaliação, somente as práticas de jogo do planejamento e ritmo sustentável foram de fato eficientes. As práticas de integração contínua e propriedade coletiva do código não foram adotadas por resistência dos 
alunos. Lappo conclui seu estudo apontando que alunos que não passaram por experiências com métodos tradicionais não dão valor às diferenças propostas por métodos ágeis. Noll e Atkinson [NA03] descrevem um curso de 10 semanas no qual equipes seguindo metodologias tradicionais conseguiram entregar mais funcionalidades (e também mais defeitos) do que equipes que optaram por XP, que por sua vez produziram código mais robusto. Nota-se que as equipes "ágeis" não conseguiram seguir algumas práticas como envolvimento real com o cliente, integração contínua e propriedade coletiva do código. O estudo apóia a hipótese de Lappo que alunos dão valor aos métodos ágeis somente após sofrer com métodos tradicionais.

Com uma visão mais crítica sobre o valor de XP, Schneider e Johnston [SJ03, SJ05] utilizaram o método parcialmente em projetos finais de 15 alunos do quarto ano, com duração de 2 semestres. Os alunos trabalhavam em duas equipes, juntos por 10 horas semanais em um laboratório dedicado. Os autores apontam que nem todas práticas de XP são adaptáveis ao contexto acadêmico, algumas indo contra objetivos educacionais. Por isso, não recomendam XP como método a ser ensinado na academia, em especial pela percepção dos alunos de que XP não investe em análise de requisitos e design.

Shukla e Williams [SW02] ensinaram XP em um curso que apresentava diversos métodos a 150 alunos que trabalhavam em um jogo. Durante 4 semanas os alunos adotaram XP como método, porém as práticas de metáfora e refatoração não foram utilizadas. O estudo relata dificuldades com a adoção de testes pelos alunos, apontando que alguns grupos só codificaram testes automatizados no final do projeto para obter nota. Em especial, testes de aceitação tiveram muita resistência, mesmo sendo escritos pelos próprios professores e utilizados para avaliar o desempenho dos projetos. Eles concluem que XP não pode ser apresentada sem complementos, em especial técnicas de UML, e sugerem um método híbrido no qual algumas práticas tradicionais seriam utilizadas em conjunto com práticas ágeis para não renegar aspectos considerados importantes no design de aplicações.

Já Noble et al. [NMMB04] relatam uma experiência na Nova Zelândia na qual estudantes cursando a disciplina de projeto de conclusão, historicamente centrada em documentos que valiam $80 \%$ da nota enquanto software funcional contava somente $10 \%$, em grupos de 4 a 7 pessoas poderiam optar por utilizar Programação eXtrema. Os estudantes tiveram doze semanas para desenvolver um projeto para clientes externos com alunos do ano anterior atuando como treinadores. O estudo ressalta que os grupos que optaram pela metodologia ágil produziram software de mais qualidade e trabalharam menos tempo em comparação com os outros.

Com uma visão mais otimista, Holcombe et al. [HGM01] relatam adaptações a um curso existente, no qual 25 alunos do quarto ano, em grupos de 5, participaram de uma empresa júnior durante 10 horas semanais, com clientes reais de empresas parceiras da universidade, em 12 semanas de trabalho. Eles apontam que clientes reais são essenciais para o processo. Continuando este estudo SyedAbdullah et al. [SAHG03] relatam que o sucesso de projetos é diretamente proporcional ao número de práticas de XP adotadas. Em especial a prática de pequenos releases aumenta a satisfação dos 
clientes com o processo.

Apontando XP como uma alternativa viável, Tomek [Tom02b] apresenta sua experiência de ensino em dois pequenos cursos de Ciência da Computação para grupos de 4 e 8 alunos trabalhando 3 horas semanais durante um semestre. Ele ressalta a importância de criar um ambiente ágil e para isso usa o VisualWorks Smalltalk. No seu primeiro curso, dois projetos foram desenvolvidos: um inicial para que os alunos se ambientassem com XP, seguido de um projeto realista. Em ambos, Tomek atuou como treinador e cliente. No segundo curso, concentrou-se em um único projeto com um cliente verdadeiro. Ele recomenda que algumas práticas de XP sejam introduzidas mais cedo na grade curricular universitária. Ainda mais, diz que as disciplinas de Engenharia de Software e de trabalho de conclusão do curso podem ser mais efetivas adotando XP, ressaltando a importância de adotar todas as práticas e de contar com um cliente externo.

Pechau et al. [BPBLS03] relatam a experiência de oferecer um projeto de três semanas aos alunos no final do primeiro ano de Ciência da Computação em uma universidade na Alemanha. Neste projeto, uma semana de programação intensa se baseia nas práticas de XP, na qual 3 grupos de 12 a 18 alunos treinados por professores com experiência em XP, que também atuam como clientes, tem sua própria sala de trabalho. Nota-se que alunos de primeiro ano ainda não têm a experiência necessária para compreender todas as práticas, porém aprendem muito sobre trabalhar em grupo e sentem-se motivados pelo projeto. McKinney et al. relatam experiência semelhante com alunos de primeiro ano [MFR ${ }^{+}$04], porém em um curso de duração de um semestre. Eles notam que o instrutor não deveria se sobrecarregar com o papel de cliente.

Mugridge et al. [MMRT03] descrevem experiências mais bem sucedidas em 3 instâncias de um curso anual. Porém relatam dificuldades com as práticas de ritmo sustentável e envolvimento real com o cliente. Muller et al. [MT01] ressaltam a importância do treinador no contexto universitário para ajudar na prática de testes e de implantação incremental. Eles ampliam seus estudos para propor uma semana dedicada ao desenvolvimento de um projeto em vez de pequenas aulas práticas ao longo do curso [MLSM04].

Hedin et al. [HBM03b] também ressaltam a importância de treinadores dedicados em um curso de 7 semanas com 107 alunos do segundo ano que se encontravam durante 8 horas em um dia por semana. O projeto começou com uma base de código oferecida pelos professores. Eles apontam o sucesso de usar alunos da instância da disciplina no ano anterior como treinadores. Os autores observam os mesmos problemas da maioria das experiências aqui citadas, como dificuldades para ensinar testes, adotar corretamente a prática de design simples e sobrecarga de trabalho do professor que assume papel de cliente. Ressaltam ainda a importância de alocar as equipes em salas dedicadas ao projeto. Aprimorando estes estudos, Hedin et al. relatam sua experiência positiva ensinando grandes grupos de alunos em duas disciplinas que funcionavam em conjunto; uma sobre programação em grupo utilizando XP, para 100 alunos, e outra específica para 25 alunos que cursaram a primeira, na qual assumem o papel de treinadores da primeira disciplina [HBM03a, HBM05]. 
Em sua pesquisa, Dubinsky [HD03, Dub03,DH04] relata experiências em 5 cursos semestrais, nos quais 325 alunos trabalharam em 25 projetos. Ele sugere alguns princípios de ensino de métodos de desenvolvimento e como eles são evidenciados no ensino de XP. Dubinsky recomenda ainda que cada membro das equipes, além de atuar como desenvolvedor, tenha um papel especial relacionado com as práticas de XP, como por exemplo ser responsável por testes de aceitação, para que os alunos se responsabilizem ainda mais pelo processo.

Finalmente, Muller [Mü104] relata as dificuldades encontradas ao adotar XP em um projeto complexo. Durante 6 meses, uma pequena equipe de 4 alunos desenvolveu uma máquina virtual Java. Devido à alta complexidade algorítmica do projeto, algumas adaptações ao jogo do planejamento foram propostas.

Na próxima sessão, descreveremos em detalhes a experiência do nosso grupo, que vem ensinando $\mathrm{XP}$ em um contexto acadêmico nos últimos 7 anos [GKSY04].

\subsection{Laboratório de XP - 2001 a 2007}

Desde 2001, a disciplina Laboratório de Programação eXtrema é oferecida como optativa no currículo de graduação e pós-graduação em Ciência da Computação do IME/USP [GKSY04, $\mathrm{FGF}^{+}$04, FGK05]. A disciplina é voltada à prática e dura um semestre. Ela conta com poucas aulas teóricas que descrevem o método no início do curso e com duas a quatro sessões práticas por semana durante os outros três meses e meio. O curso é voltado especialmente para alunos do terceiro e quarto ano da graduação e alunos de pós-graduação, já com alguma experiência de desenvolvimento. Ao longo das instâncias do curso, o número de participantes inscritos variou entre 6 e 43 pessoas, que na média se organizaram em grupos de 6 . Este fato é relevante pois oferecemos aos alunos a oportunidade de trabalhar em grupos grandes, já que a maioria das disciplinas trabalha com grupos muito menores. Em sete anos, a disciplina foi oferecida seis vezes e 18 equipes trabalharam em 9 projetos distintos. No total, 120 alunos foram beneficiados pela disciplina. A medida que ganhamos experiência, o número de vagas aumenta, atualmente oferecemos 50 vagas.

Em sua primeira instância, no segundo semestre de 2001, dois grupos de seis alunos desenvolveram soluções distintas para um mesmo sistema de controle de carga didática sugerido pelos professores. $\mathrm{O}$ sistema deveria contar com uma interface para coletar informações sobre as disciplinas oferecidas por um departamento de uma universidade, além das necessidades e desejos de alunos e professores. Com estas informações, o sistema deveria sugerir um possível horário para as disciplinas com seus respectivos instrutores. Apenas um dos grupos conseguiu colocar parte do sistema em produção [ $\left.\mathrm{FGF}^{+} 04\right]$. Mais adiante iremos detalhar esta primeira experiência, na qual o autor participou como aluno de graduação.

Em 2002, os professores sugeriram que um grupo de seis alunos desenvolvessem um sistema para resolver o problema da escolha dos livros a serem comprados pelo Departamento de Ciência da Computação, a partir de sugestões dos docentes e critérios escolhidos pelo operador do sistema. 
Em 2003, os alunos, divididos em equipes de 8 e 9 pessoas, desenvolveram módulos diferentes de um sistema de controle do acervo da biblioteca do IME/USP, o Colméia. O primeiro grupo desenvolveu o controle dos periódicos da biblioteca, enquanto o segundo desenvolveu o módulo de empréstimo de livros e outros materiais. Esta foi a primeira experiência onde um cliente externo, o presidente da comissão da biblioteca do instituto, participou do laboratório.

Em 2004, 3 equipes (de 3, 8 e 11 alunos) participaram da disciplina. A primeira equipe desenvolveu um sistema em Smalltalk para marcar reuniões. A segunda continuou o desenvolvimento do Colméia, iniciado no ano anterior. A terceira desenvolveu um software livre para distribuição e compartilhamento de arquivos multimídia, para ser utilizado no projeto "Pontos de Cultura" do Ministério da Cultura; foi a primeira experiência com clientes externos ao IME [FGK05]. Estes projetos, nos quais o autor atuou como auxiliar de ensino, serão descritos em mais detalhes a seguir.

Em 2005, a disciplina não foi oferecida devido a uma mudança da grade de horários. A partir desse ano ela passou a ser oferecida no primeiro semestre, evitando concorrência com laboratório de banco de dados. Desta maneira, alunos em um semestre podem modelar um banco de dados neste laboratório e no próximo semestre implementar uma aplicação que utiliza o banco no laboratório de XP.

Em 2006, a disciplina contou com 5 equipes. Uma equipe com 8 alunos continuou o desenvolvimento do Colméia. Outra equipe de 8 alunos se envolveu com o desenvolvimento do Archimedes, um software CAD de código aberto para desenho técnico e de arquitetura. O sistema tinha uma base de código disponível como software livre e havia sido desenvolvido usando XP. Uma equipe de 4 alunos deu continuidade a Borboleta, uma plataforma móvel para auxílio a médicos que fazem atendimento domiciliar, iniciada como projeto de formatura em 2004. Uma equipe de 6 alunos iniciou o desenvolvimento de um aplicativo para auxiliar no tratamento e prevenção de Lesões por Esforço Repetitivo (LER), o GinLab. Finalmente, uma equipe de 6 alunos desenvolveu um sistema que se utiliza de uma grade computacional para realizar conversões entre diferentes formatos e codificações de vídeo.

Em 2007, 43 alunos participaram da disciplina. Nesta instância todos os projetos foram continuações de projetos anteriores do laboratório. O desenvolvimento do Archimedes continuou com um grupo de 9 pessoas. O Borboleta foi aprimorado por um grupo de 11. O GinLab prosseguiu com 9 alunos. O Colméia contou com dois grupos, um de 10 pessoas que desenvolveu o módulo de buscas, e outro de 4 pessoas que trabalhou em um módulo específico, o Zumbido, responsável por transferir dados entre bibliotecas diferentes.

A seguir, descreveremos o funcionamento do laboratório, aspectos acadêmicos e adaptações das práticas. Após esta exposição descreveremos em mais detalhes um dos projetos do primeiro ano, no qual fui aluno, e os três projetos do quarto ano, quando atuei como auxiliar de ensino. 


\subsubsection{Como funciona o Laboratório}

A disciplina conta com um laboratório especialmente preparado e de uso exclusivo durante as aulas. Na Figura 3.1 vemos o espaço disponibilizado para uma equipe e na Figura 3.2 vemos outra equipe ocupando suas estações de programação pareada.

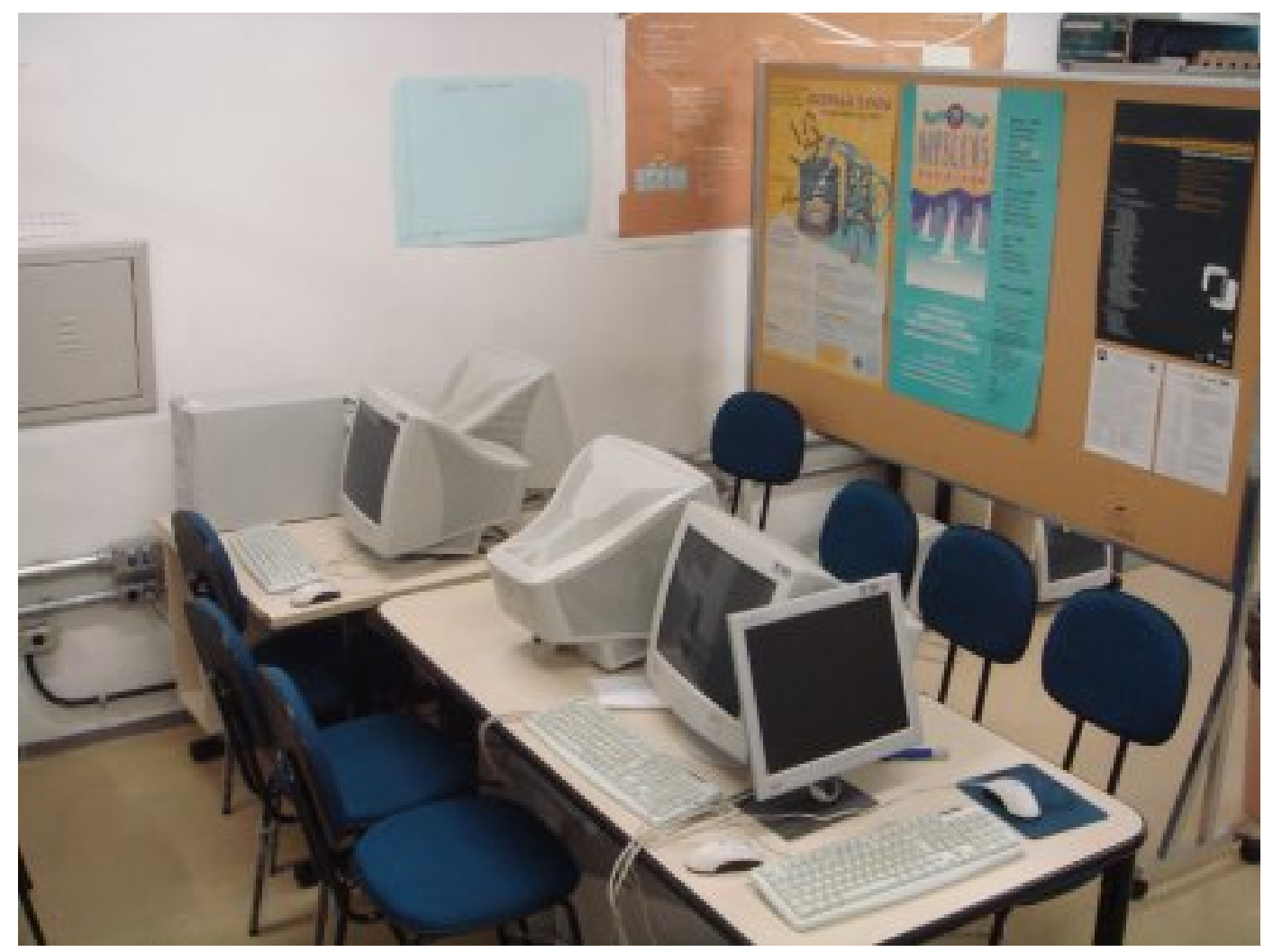

Figura 3.1: O espaço do laboratório de Programação eXtrema

O laboratório conta com sua própria rede de computadores configurados com sistema Debian GNU/Linux e com ambientes de desenvolvimento devidamente instalados baseados em Eclipse. Além disso, um servidor possibilita acesso externo à rede, fornece serviços de integração contínua (CVS e Subversion) e disponibiliza sistemas para organização das equipes como Wikis e o XPlanner. Vale ressaltar que o laboratório conta com um aluno bolsista que cuida da administração e manutenção desta infra-estrutura.

Este laboratório foi montado seguindo sugestões de Cockburn para aumentar a eficiência da comunicação, de acordo comr o Capítulo 3 de Communicating, Cooperating Teams [Coc02]. Há espaço para dois desenvolvedores sentarem em cada computador e para membros de uma mesma equipe sentarem de frente uns para os outros. Na Figura 3.3 vemos um par atuando para resolver uma tarefa em uma estação de trabalho do laboratório.

Além disso, cada equipe conta com espaço nas paredes para posicionar radiadores de informação 


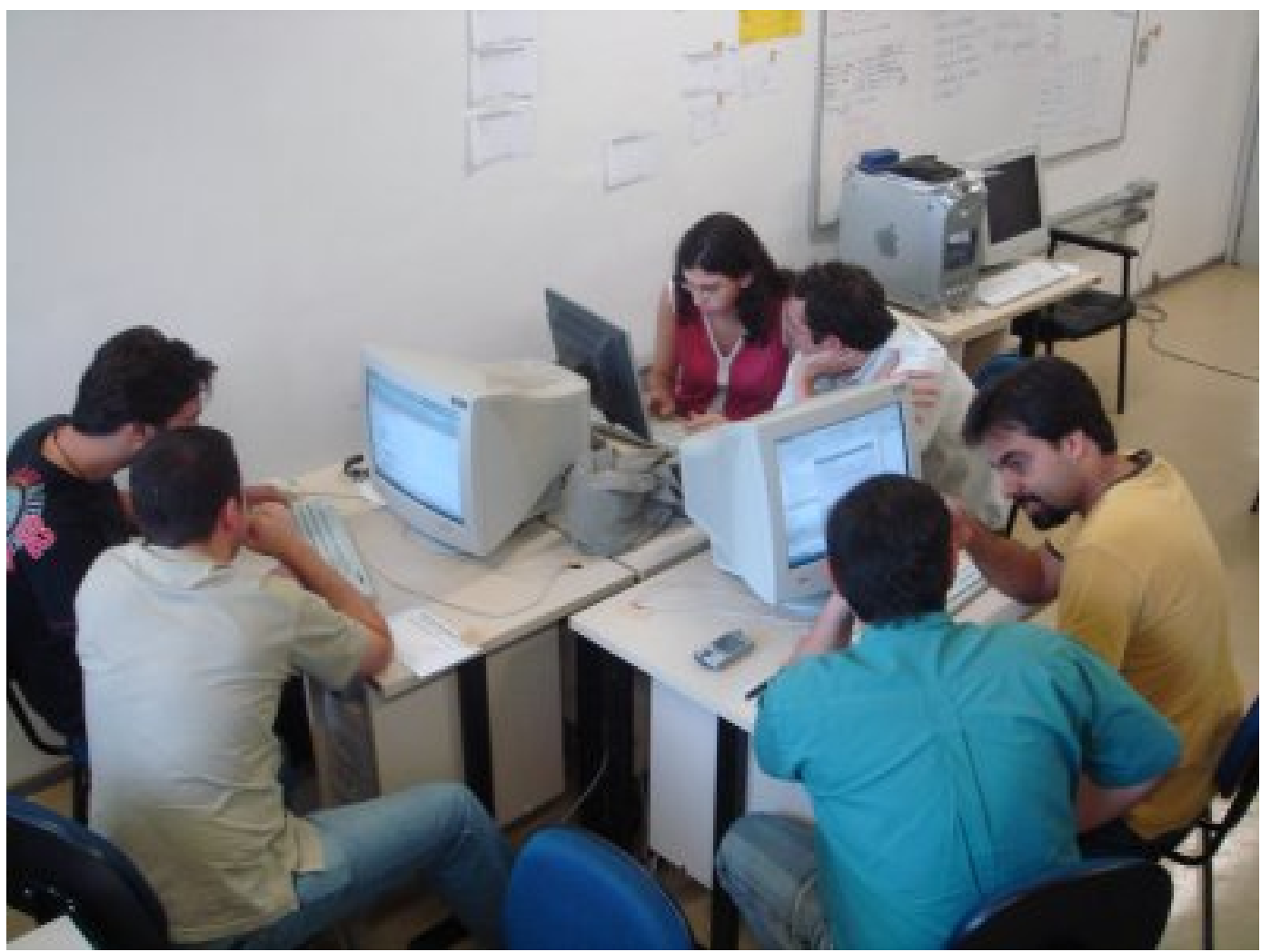

Figura 3.2: Uma equipe ocupa suas estações de programação pareada no laboratório

e ainda espaço em um quadro branco, que está posicionado no centro da sala, servindo para separar as diversas equipes. Desta maneira o espaço do laboratório permite comunicação entre membros de diferentes equipes, durante o almoço, conversas e através dos radiadores de informação. Permite também uma comunicação mais eficiente entre membros de uma equipe, devido ao posicionamento das mesas, do quadro e dos computadores. Nas figuras 3.4 e 3.5 vemos os radiadores de informação.

A carga didática da disciplina reflete o contexto acadêmico; os alunos devem comparecer a duas aulas semanais uma de 2 horas e outra de 3 horas. Estes aulas são sessões práticas nas quais eles desenvolvem seu projeto de acordo com XP, adotando todas as práticas. Diferente da maioria das disciplinas, optamos por não realizar provas. A nota dos alunos é composta pelo engajamento em seguir o método (35\%), pela freqüência nas aulas (30\%), a qualidade do software produzido (25\%) e uma auto-avaliação (10\%). Fica claro que o maior objetivo do curso é que os alunos se dediquem a aplicar a metodologia e compareçam a todas as aulas.

Normalmente, a aula de 3 horas engloba o almoço. Aproveitamos o horário para oferecer comida aos alunos para que possam aproveitar e alongar sessões de programação pareada. Denominamos está prática "almoço extremo". Observamos que estas sessões são mais produtivas do que as de 2 horas e que o almoço extremo, apesar de modesto, ajuda os alunos a relaxarem criando uma oportunidade 


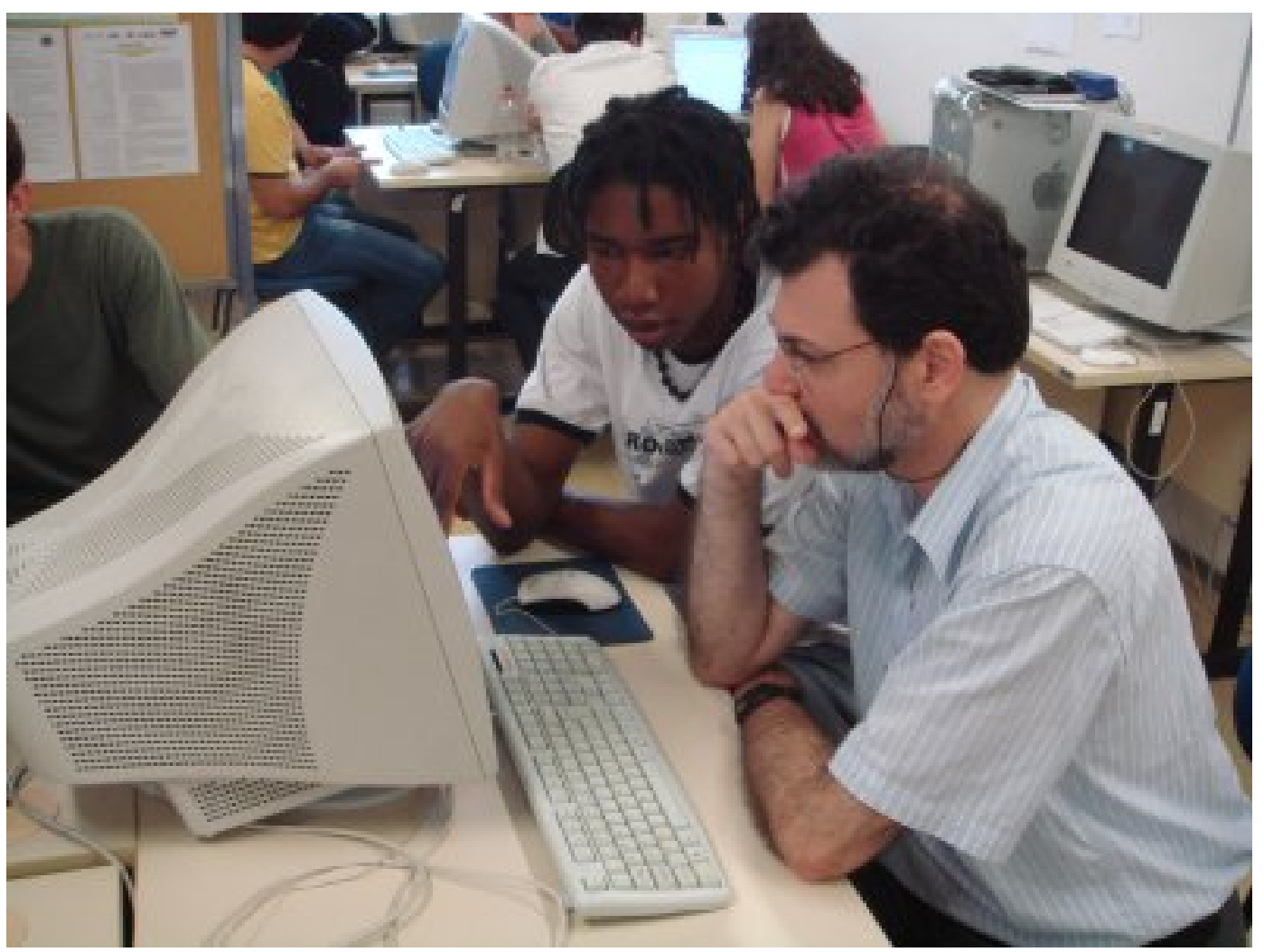

Figura 3.3: Um par desenvolvendo seu sistema e engajado na resolução de uma tarefa

para aumentar a comunicação entre eles. Durante o almoço, em geral sandwíche de metro patrocinado por alguma empresa colaboradora, alunos conversam sobre os sistemas e trabalham em pares com lanches em mãos. A importância de comida no ambiente de trabalho foi ressaltada por Beck [Bec99]. Na Figura 3.6, vemos dois professores que também atuam como clientes discutindo os projetos durante o almoço extremo.

Além das duas aulas mencionadas, é fortemente sugerido aos alunos que trabalhem de duas a quatro horas extras por semana no laboratório, em sessões de programação pareada ou pesquisando tecnologias usadas nos projetos. Porém, estas horas não são contabilizadas pelos professores, e não valem presença para avaliação do curso. Na prática, os alunos trabalham no laboratório, também trabalham em casa e chegam até a fazer sessões de programação pareada remotamente. Porém, alguns alunos não se dedicam as horas extras justamente por não serem obrigatórias.

Para a formação das equipes, os professores sugerem sistemas que poderão ser desenvolvidos e os alunos se agrupam de acordo com seus interesses. A escolha final fica a critério dos alunos, que também podem sugerir outros projetos e tem autonomia sobre a escolha das tecnologias que serão usadas no desenvolvimento.

Foi importante escolher bem os sistemas que iríamos sugerir. Primeiro para que existissem de 


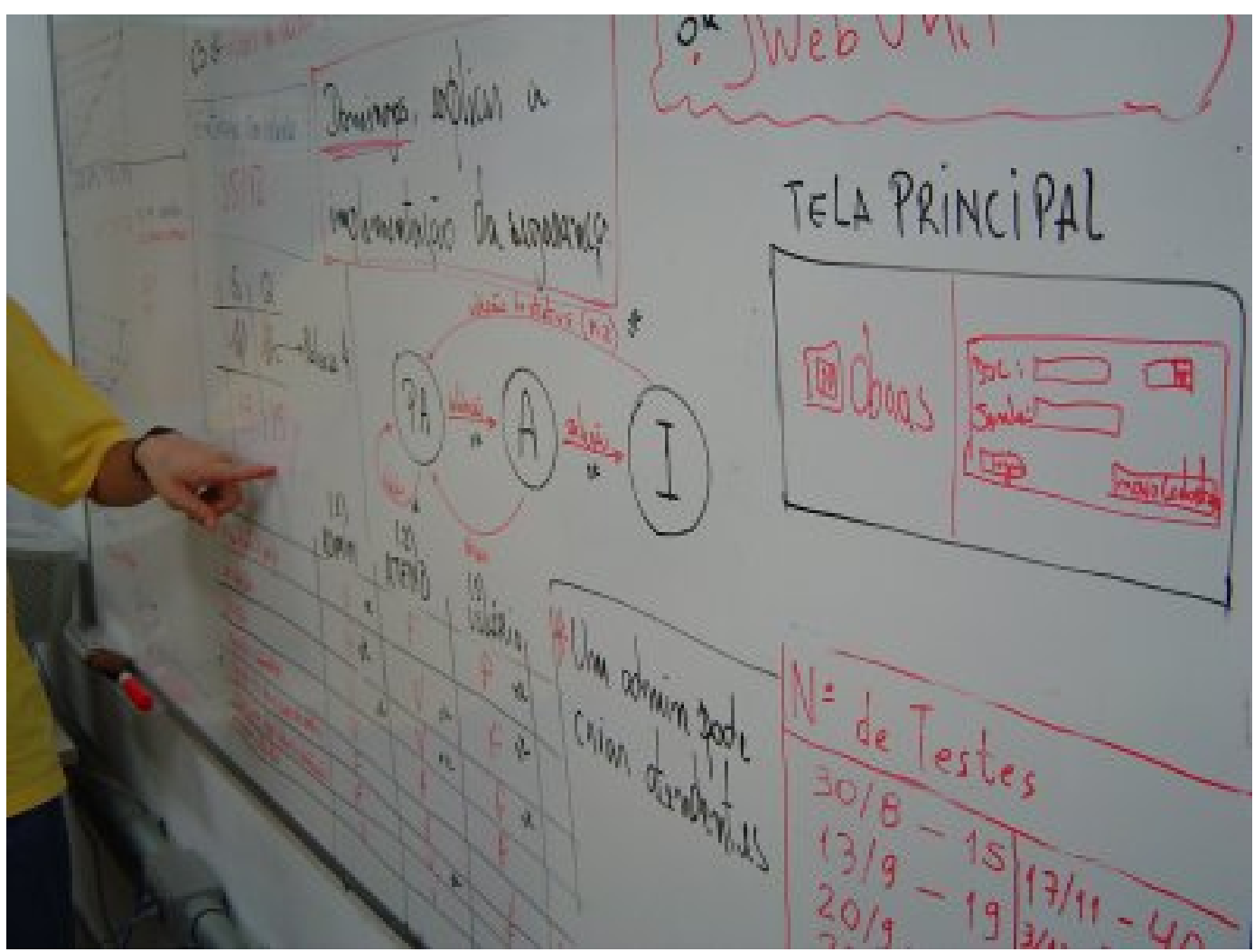

Figura 3.4: O quadro branco de uma equipe sendo utilizado como radiador de informações

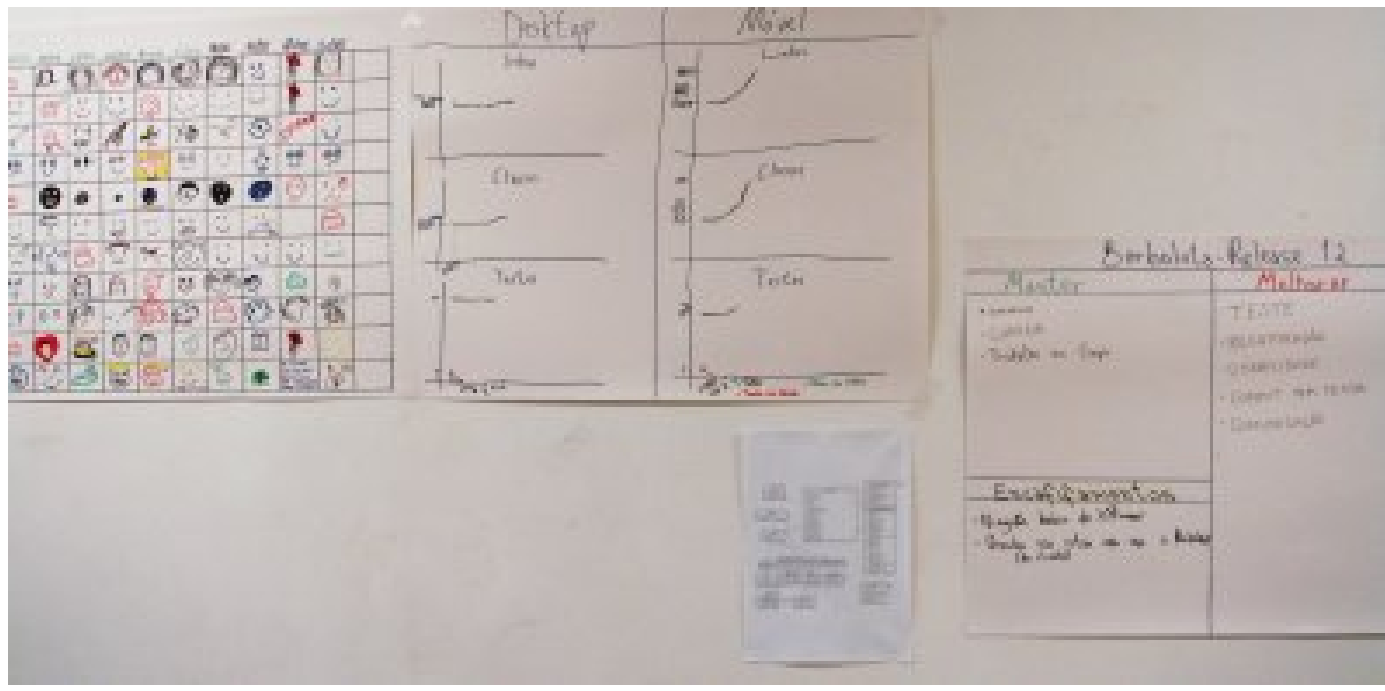

Figura 3.5: Radiadores de informações colados na parede: um calendário Niko-Niko; a evolução do número de linhas, classes e testes nos diferentes módulos do sistema; um diagrama UML e o resultado de uma retrospectiva 


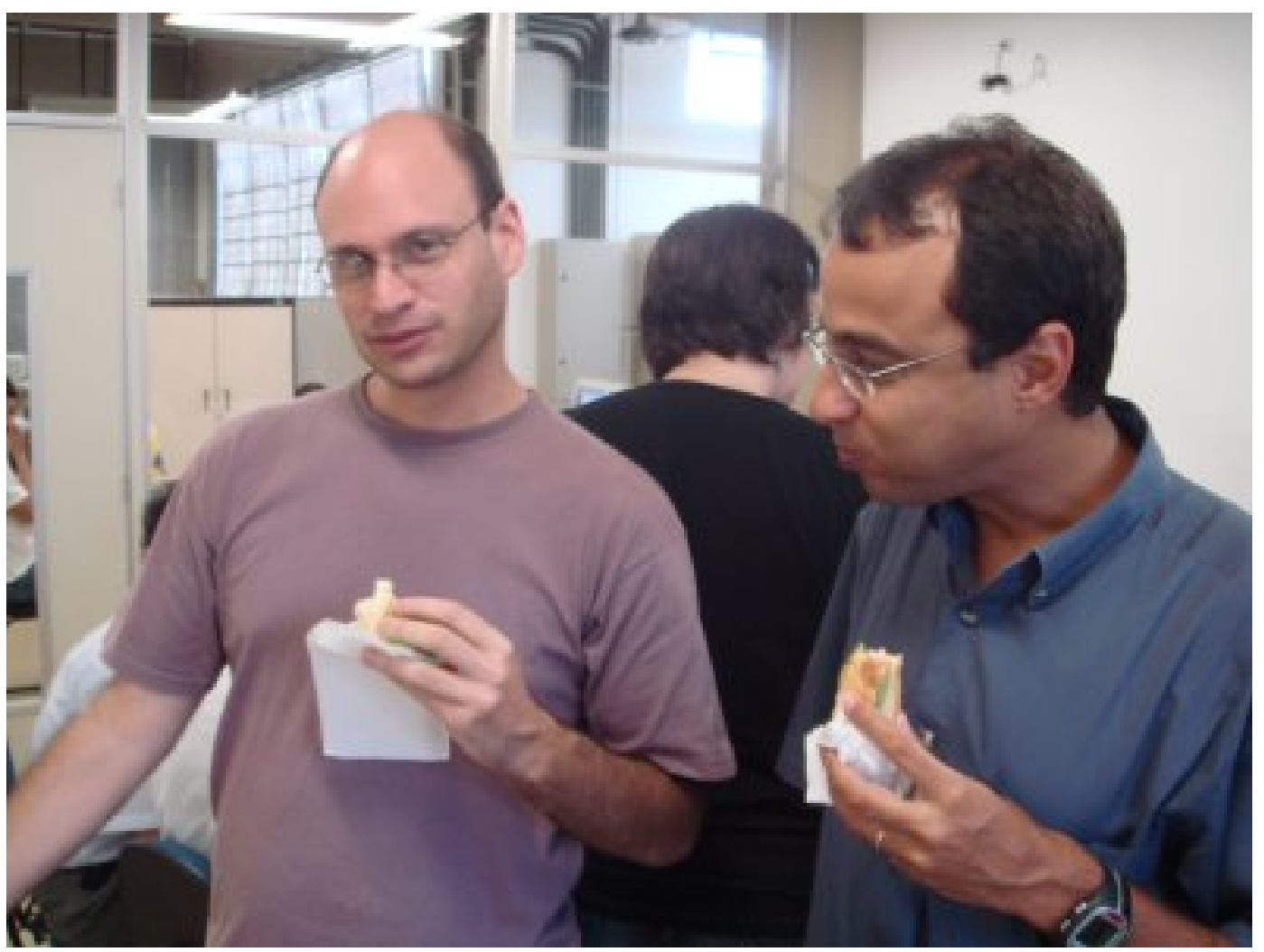

Figura 3.6: Dois professores que também atuam como clientes refletem sobre os projetos em andamento durante o almoço extremo

fato clientes e potenciais usuários para interagir com a equipe. Segundo para que fossem desafios interessantes do ponto de visto tecnológico e motivassem os alunos.

Em cada equipe, um aluno escolhe voluntariamente atuar como acompanhador e fica responsável por atualizar os radiadores de informação de seu grupo. Os acompanhadores recebem literatura específica sobre seu papel e são sempre motivados a desempenhar suas funções. Eles também mantêm, normalmente, versões on-line das histórias relativas aos seus sistemas. Algumas vezes surge uma competição saudável entre os acompanhadores de diversas equipes transformando o laboratório em uma verdadeira exposição de radiadores de informação. A Figura 3.7 mostra o acompanhamento da evolução do número de testes de um projeto e a Figura 3.8 mostra histórias documentadas on-line no XPlanner visualizadas no sistema que roda no laboratório.

Nas primeiras instâncias da disciplina, os professores atuavam como treinadores e também como clientes, já que seriam usuários dos sistemas desenvolvidos. Ao longo dos anos, evoluímos nossa prática para que clientes externos participem. Essa experiência ajudou o laboratório a ser mais realista, pois alunos agora lidam com clientes que não são da área de Ciência da Computação. Além disso, agora é possível para alunos que já cursaram a disciplina cursá-la novamente, especializando-se no papel de treinador. 


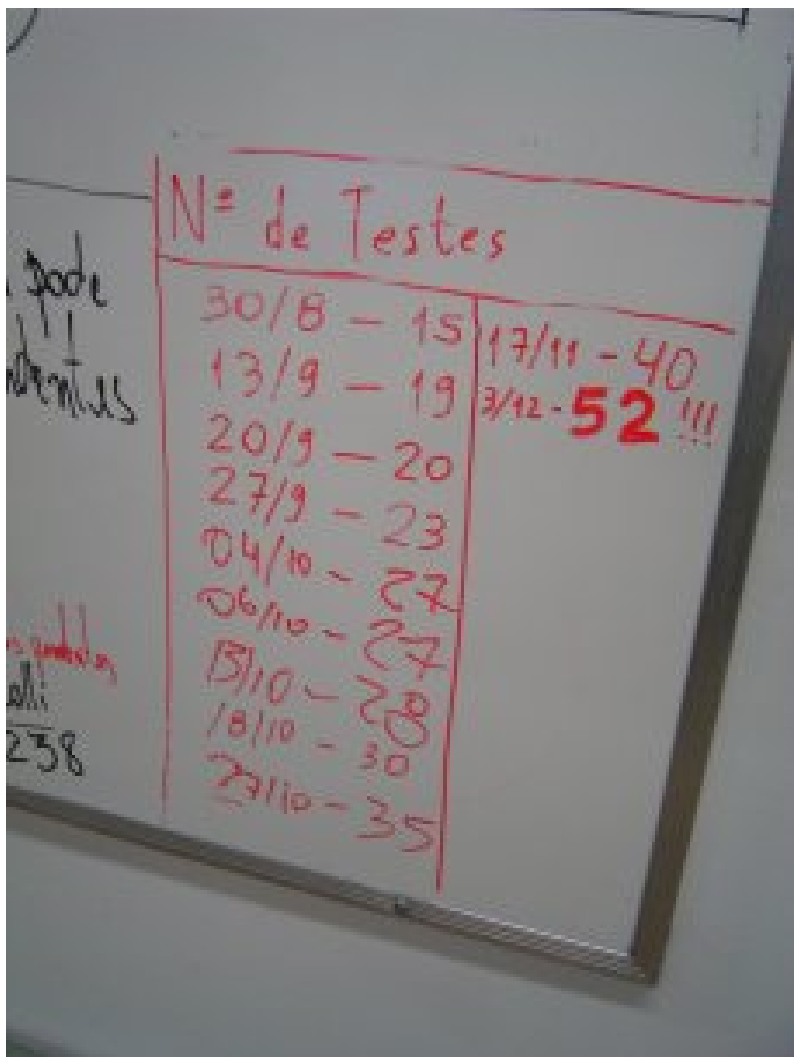

Figura 3.7: Evolução de número de testes de uma equipe detalhada numa tabela pelo seu acompanhador

Como neste contexto os alunos passam menos tempo no laboratório do que num contexto industrial, algumas práticas tiveram que ser adaptadas. O jogo do planejamento dos diferentes projetos tenta separar releases com poucas histórias (de 5 a 10), que devem ser implementadas em até quatro semanas. Em muitos casos tivemos que utilizar clientes proxy, pois os verdadeiros clientes não podiam comparecer a todas as aulas. Tentávamos fazer com que os clientes reais participassem de jogos do planejamento e de apresentações dos releases. A Figura 3.9 mostra a apresentação de um release do Borboleta aos seus clientes, enfermeiras do Centro de Saúde do Butantã, da Faculdade de Medicina da USP. O ritmo sustentável foi estabelecido para refletir as 10 horas sugeridas de trabalho semanal. As outras práticas foram utilizadas sem maiores adaptações. Além das práticas comuns, as equipes têm a liberdade de adotar outras práticas ágeis em seus contextos. Sugerimos sempre o uso de papos-em-pé e retrospectivas, que nos últimos anos tem sido bastante utilizadas.

A seguir iremos descrever experiências específicas em quatro projetos desta disciplina.

\subsubsection{Mico - Sistema para administração de carga didática - nossa primeira experiência}

O autor passava pela sua primeira experiência profissional real, desenvolvendo sistemas para uma multinacional na Itália, na qual durante um ano lidou com a frustração de ser um dos programadores 


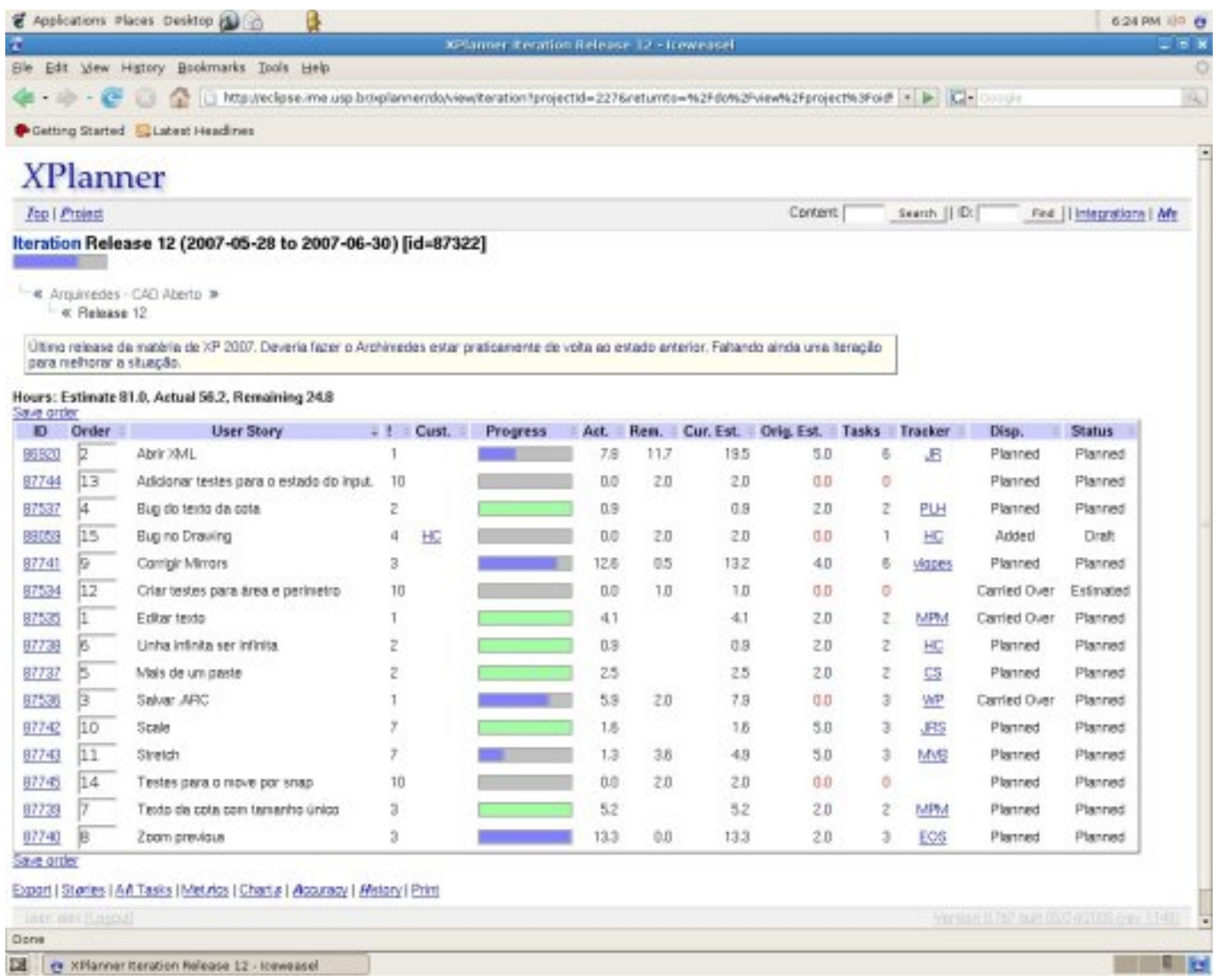

Figura 3.8: Histórias de uma equipe on-line no XPlanner.

mais qualificados da equipe e ao mesmo tempo ter que atuar politicamente na empresa e tentar coordenar o desenvolvimento de vários programadores trabalhando em três sistemas diferentes. Foi quando recebeu o e-mail convite dos professores para participar de uma nova disciplina optativa no IME/USP, o Laboratório de Programação eXtrema. Ao ler as referências, se encantou com as soluções propostas aos problemas reais que estava enfrentando e resolveu voltar ao Brasil para terminar seu curso de graduação.

Na primeira instância do Laboratório de XP, 12 alunos se dividiram em dois grupos e se dedicaram a resolver o mesmo problema: desenvolver um sistema para administração de carga didática do departamento de Computação. Na sua primeira experiência de ensino de XP, três professores revezavam nos papéis de treinadores e clientes de ambas equipes.

Uma das principais tarefas administrativas de escolas e universidades é a construção do cronograma de aulas e a conseqüente alocação de professores aos cursos que devem lecionar em um período. Muitas restrições são importantes nessa alocação: alunos têm preferências de disciplinas optativas e períodos nos quais elas devem ser oferecidas, professores tem suas próprias preferências de cursos e horários e o departamento deve satisfazer suas necessidades curriculares. Achar um cronograma 


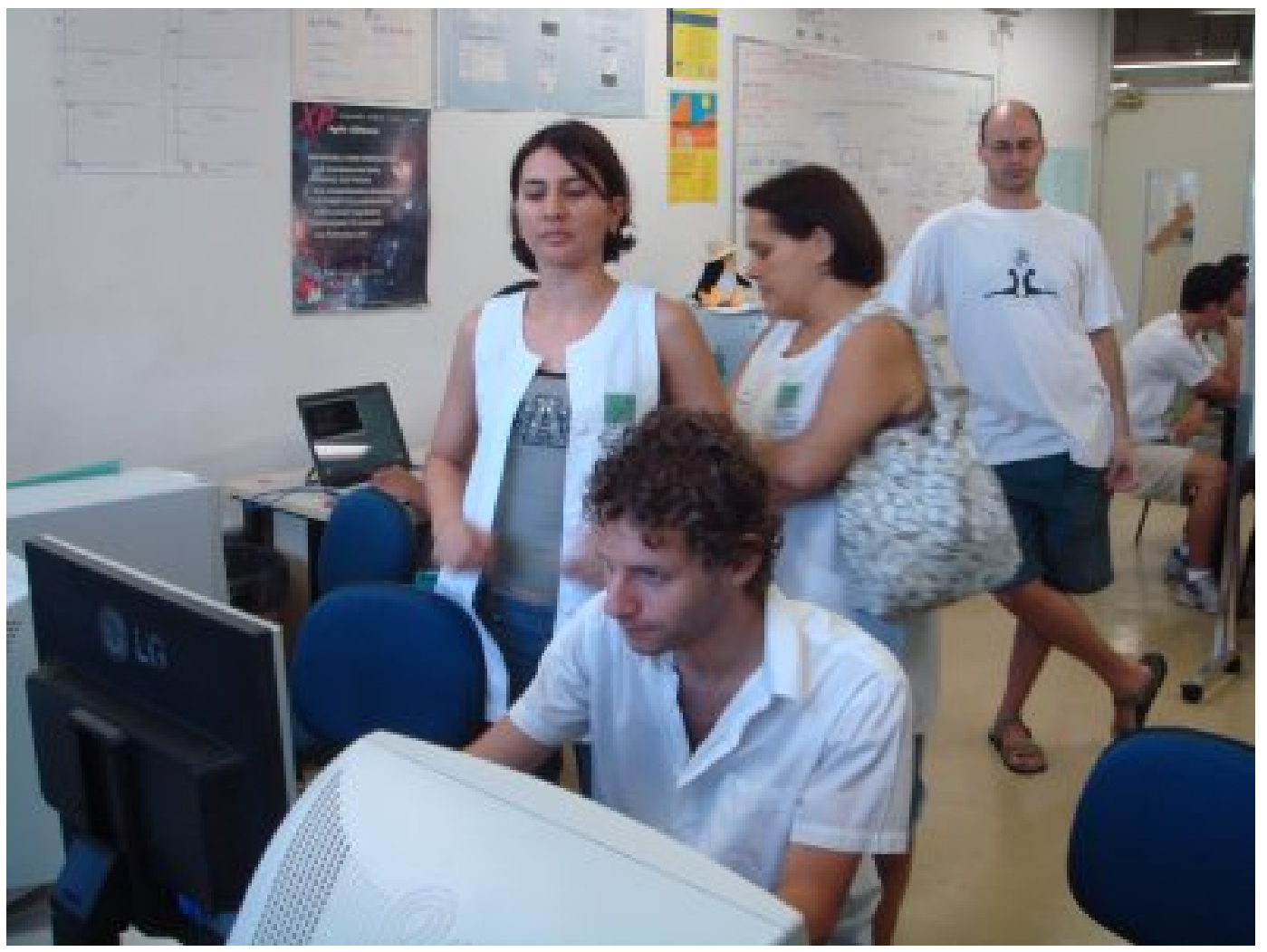

Figura 3.9: Enfermeiras clientes do Borboleta acompanham a apresentação de um release.

e alocar professores é uma tarefa complexa que o departamento encara todos os anos. Por não conhecer nenhum software que resolvia o problema, os professores sugeriram este como o primeiro desafio do laboratório. Assim como os alunos, eles seriam usuários do sistema, devendo indicar suas preferências. Além disso, se beneficiariam de sua existência.

A proposta era criar um sistema baseado na Web onde alunos e professores indicariam suas preferências para o ano letivo seguinte. Professores diriam qual horário e dias da semana estariam disponíveis para aulas, além de quais disciplinas tinham competência para ensinar. Os alunos escolheriam quais cursos gostariam de participar e votariam em disciplinas optativas que gostariam que fossem oferecidas. A aplicação então usaria um algoritmo genético para achar um cronograma otimizado e alocar professores aos cursos que deveriam lecionar.

Ambas equipes se dedicaram ao mesmo problema, porém optaram por usar tecnologias diferentes; durante os jogos de planejamento, negociaram as prioridades de histórias de maneira distinta com seus clientes. Enquanto uma equipe deu prioridade ao desenvolvimento do algoritmo genético, usando $\mathrm{C}++$, a outra começou desenvolvendo a interface Web e optou por Java e arcabouços livres e abertos disponíveis para esta linguagem.

Ambas equipes tiveram problemas com testes automatizados. Uma delas porque o algoritmo a 
ser testado era muito complexo. A outra por ainda não existirem naquela época arcabouços de testes automatizados para interfaces Web. Além disso notamos que os professores tinham dificuldade em separar bem as preocupações que tinham como clientes ou treinadores, pois exerciam ambos os papéis simultaneamente. Curiosamente, a adoção do algoritmo genético foi importante para criação de uma metáfora comum para o desenvolvimento.

Ao final da disciplina, uma equipe conseguiu entregar uma versão quase funcional do algoritmo genético. A outra entregou uma interface Web completamente funcional, mas que só armazenava os dados necessários e não resolvia o problema. Após a disciplina, dois alunos continuaram o desenvolvimento do sistema, tentando integrar o algoritmo genético a interface Web (sem sucesso) e posteriormente tentando implementar um novo algoritmo (também sem sucesso). Esta experiência foi relatada em artigo [ $\mathrm{FGF}^{+}$04]. Mesmo sem o algoritmo funcional, o sistema foi colocado em produção e usado durante quatro anos para coletar preferências dos alunos e professores para posterior criação da carga didática do departamento.

\subsubsection{Marcador de Reuniões - grupo pequeno utiliza Smalltalk}

Nesta instância da disciplina, uma equipe composta por 3 alunos e um professor que atuava como cliente, treinador e também programador desenvolveu uma aplicação Web para marcar reuniões.

O projeto surgiu da necessidade dos professores do IME-USP de ter uma ferramenta para gerenciar suas reuniões. Um usuário cadastrado no sistema pode criar uma reunião, indicando em quais datas e horários ela poderia ocorrer e convidando outros usuários. Cada convidado pode indicar quais são os horários que ele prefere. O sistema então mostra ao usuário que convocou a reunião qual o melhor horário. Ele seleciona sua preferência e pode também reservar uma sala.

A equipe começou com uma base de código existente, resultado do trabalho final da disciplina de programação orientada a objetos oferecido no semestre anterior, na qual o autor também foi auxiliar de ensino. Os alunos escolheram entre 3 projetos em Smalltalk e optaram por dar continuidade ao projeto que tinha a interface mais funcional. Os sistemas já contavam com uma base de testes automatizados, que havia sido desenvolvida para ajudar na avaliação da disciplina de orientação a objetos. Optou-se pelo VisualWorks Smalltalk em conjunto com os arcabouços SUnit para testes, Smalltalk Server Pages, VisualWave como servidor Web e Store para controle de versões e integração contínua. Atualmente na disciplina de programação orientada a objetos do IME/USP não mais utilizamos o VisualWorks e sim Squeak Smalltalk, versão completamente livre em conjunto com o arcabouço Seaside para geração de páginas Web.

Notamos que grande parte do sistema foi refatorada e no final, somente os testes e aspectos da interface permaneceram intactos. A presença do cliente se deu em todas as aulas, pois o professor que atuava como desenvolvedor e treinador também era cliente. Mesmo assim, como a equipe era pequena, não observamos problemas com essa prática. 


\subsubsection{Colméia - Gerenciador de Biblioteca - evolução de um projeto ao longo dos anos}

Dando continuidade ao sistema Colméia, iniciado na instância anterior da disciplina, esta equipe contava com 8 alunos, sendo que um já havia cursado a disciplina anteriormente e atuava como treinador. Junto com o código fonte que já estava pronto, os alunos herdaram também o cliente, já com alguma experiência em participar de projetos XP. Ele não podia estar presente em todas as aulas, mas participou de jogos do planejamento e avaliação de releases.

O sistema já contava com funcionalidades de controle de consulta e empréstimo de periódicos, livros e demais materiais. Nesta edição, os alunos deveriam desenvolver o módulo de controle de pessoas.

No início do projeto, os alunos se dedicaram a conhecer o sistema existente e as tecnologias adotadas. O fato de uma base de código existir foi positivo. Os alunos conseguiram adotar rapidamente um ritmo eficiente de desenvolvimento e, em entrevistas no final do curso, ressaltaram a importância do código fonte dos testes no aprendizado do sistema.

Vale notar que este grupo passou por uma experiência peculiar, quando o aluno que atuava como treinador teve que abandonar a disciplina no meio do semestre para se dedicar a uma oportunidade profissional. A solução a este impasse surgiu quando outro aluno voluntariamente aceitou o papel de treinador. Com ajuda da sua equipe, se apoiaram no uso de todas as práticas de XP e implantaram a metodologia de maneira eficiente, mesmo sendo essa sua primeira experiência.

\subsubsection{Cigarra - Distribuidor Multimídia - clientes externos em um grande projeto governamental}

A maior equipe neste semestre, com 11 alunos, se dedicou a implementar um projeto proposto em parceria com o Ministério da Cultura. O autor atuou como treinador desta equipe - veja a Figura 3.10, e também como consultor no Ministério, cliente proxy e desenvolvedor. O cigarra, como foi chamado, seria utilizado pelo projeto "Pontos de Cultura" do MinC. Os alunos ficaram motivados a participar deste projeto devido ao fato de existirem clientes reais fora do IME/USP.

A idéia do projeto "Pontos de Cultura" era apoiar projetos culturais com ação prévia comprovada em áreas remotas e periféricas do país. Previa um financiamento anual e um kit de produção multimídia, composto por dispositivos de produção de áudio e vídeo, microfones e câmeras, uma conexão de banda larga à Internet e um servidor pré-configurado para compartilhamento da rede. Pessoas de comunidades ligadas aos pontos de cultura seriam estimuladas a usar estes equipamentos e produzir músicas, filmes e outros artefatos licenciados de maneira a facilitar a distribuição do conteúdo na Internet. Todo este conteúdo cultural, em forma de vídeo, áudio, fotos e textos, seria então publicado e distribuído para qualquer pessoa interessada, em qualquer lugar do mundo.

A sugestão foi criar um sistema peer-to-peer de troca de arquivos que considerasse também o problema de publicação de dados e busca por informações. Dois requisitos eram importantes: o 


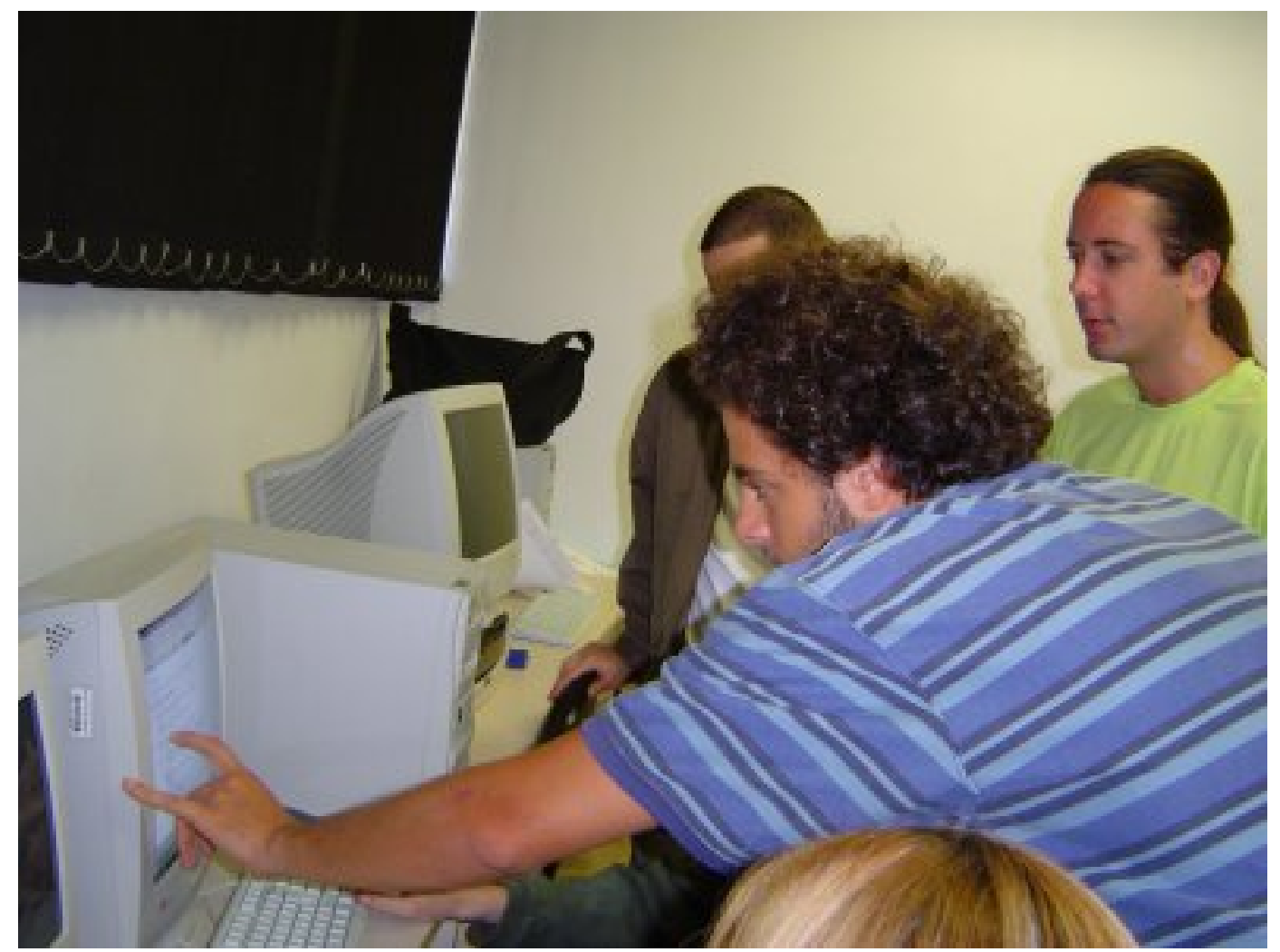

Figura 3.10: O treinador da equipe Cigarra atuando

sistema deveria ser muito fácil de usar e não poderia ter problemas de escalabilidade, pois a previsão era de que a rede de usuários publicando e acessando material poderia crescer muito rapidamente.

Durante a primeira iteração da equipe, pesquisas foram realizadas para escolha da tecnologia a ser adotada. O protocolo BitTorrent se mostrou o mais adequado, junto com a tecnologia Rich Client Application da plataforma Eclipse e o software Azureus.

O sistema foi desenvolvido em quatro releases, sendo que alguns foram testados por outro consultor do Ministério, para que o autor não precisasse atuar constantemente como treinador e também cliente proxy. Tivemos dificuldades com testes automatizados. Por mais que a acompanhadora sempre indicava a falta de testes, a equipe ficou muito ansiosa para terminar o desenvolvimento e não testou o software de maneira consistente. Este fato se refletiu numa quantidade considerável de defeitos encontrados após cada release. Na última semana de desenvolvimento, conseguimos chegar a um nível de testes aceitável, que cobria toda a aplicação. No seu último release o sistema contava com 3695 linhas de código, sendo 2995 linhas relativas às 27 classes da aplicação e 700 relativas às 17 classes dos testes. Todas as histórias mais prioritárias do cliente foram implementadas. Detalhes mais técnicos podem ser encontrados em um artigo por nós publicado no sexto Workshop sobre Software Livre do FISL 2005 [FGK05]. 
Vale notar que nesta equipe utilizamos pela primeira vez o software XPlanner para armazenar todas as histórias on-line e ainda atualizar dados sobre pareamentos e tempo gasto no desenvolvimento.

Notamos ainda que por mais que o desenvolvimento tinha começado sem base de código, utilizar software livre e de código aberto como ponto de partida se mostrou uma boa opção. Reutilizamos muito código, e tivemos a oportunidade de aperfeiçoar técnicas de testes automatizados escrevendo testes para código livre e aberto, assim contribuindo um pouco com a comunidade.

Em comparação com as outras equipes desta instância da disciplina, a equipe do Cigarra sentiu que não ter uma base de código para começar o desenvolvimento os colocou em desvantagem, atrasando o primeiro release. A Figura 3.11 mostra a reunião de apresentação do primeiro release da equipe.

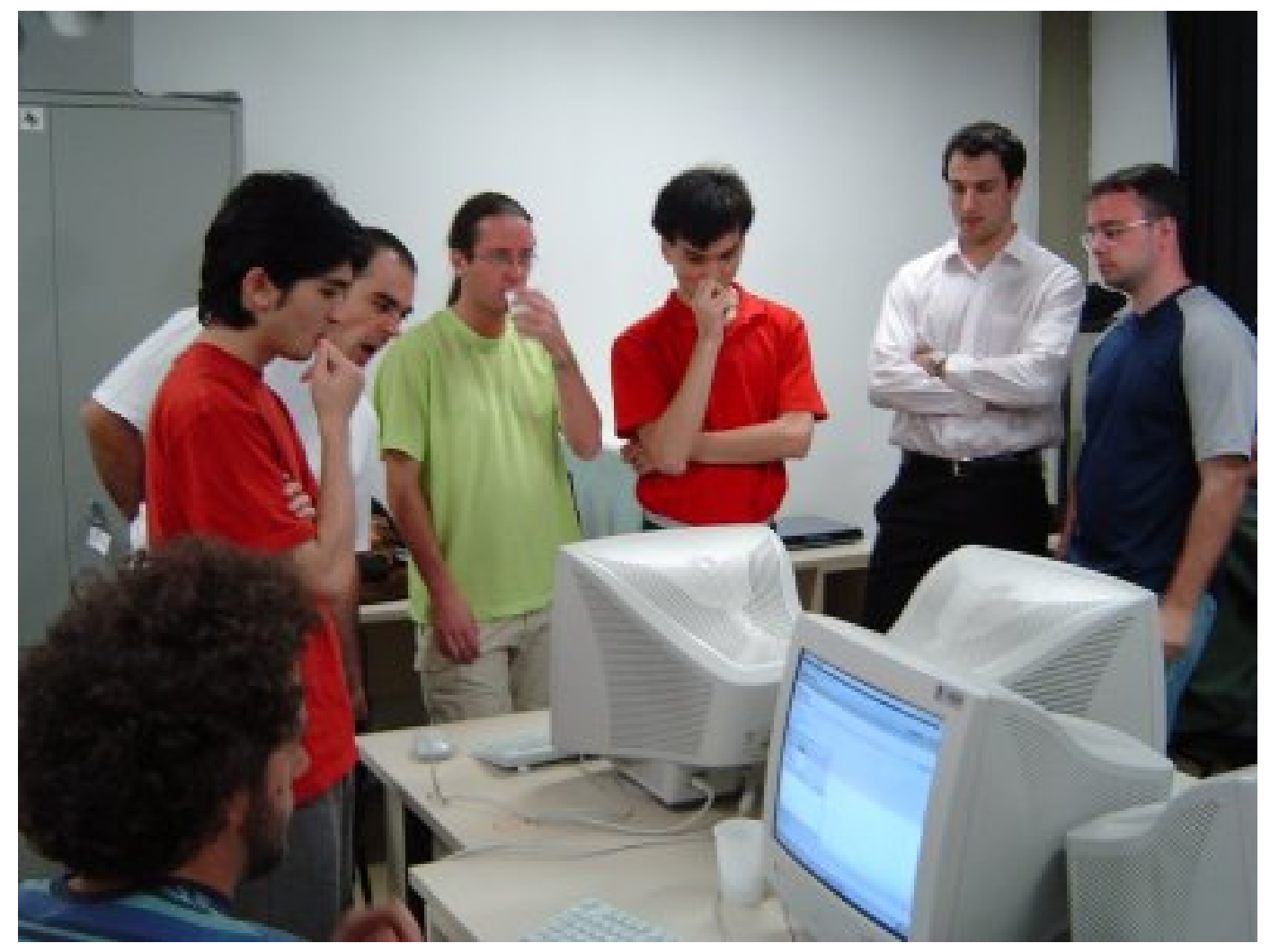

Figura 3.11: Reunião de apresentação do primeiro release da equipe Cigarra

Além disso, a equipe era grande - 12 pessoas no total - e por isso sentimos que a comunicação foi um pouco falha. Esta quantidade era o limite inicialmente proposto por Beck para fazer XP eficientemente. Como treinador, o autor tentou ao máximo melhorar a comunicação, porém o pouco comprometimento de alguns alunos, que faltaram muito, complicou este desafio. Uma nova prática proposta foi a de fazer com que os jogos do planejamento tivessem duas fases, uma presencial que durava no máximo uma hora, e outra que continuava até a próxima aula e acontecia na lista de dis- 
cussão por e-mail da equipe. Esta prática otimizou o tempo disponível para parear presencialmente. Outra prática adotada foi a de dar "créditos presença" para pares que investissem seu tempo em tarefas prioritárias nos últimos releases. Desta maneira os alunos tinham um incentivo a mais para parear fora do horário de aula e repor créditos que perderam devido a faltas.

\subsection{Trabalhos relacionados na Indústria}

Muitas empresas não utilizam nenhum método definido para o desenvolvimento de software, ainda mais em economias em desenvolvimento como no Brasil. Isso acaba deixando a programação de sistemas à mercê de seus desenvolvedores, que adotam práticas ad hoc. Um método ad hoc utiliza práticas para resolver situações específicas, sem planejamento ou consistência, e sem levar em consideração questões mais amplas ou de longo prazo.

Para melhorar a qualidade do trabalho e ter mais controle sobre os processos de produção, algumas empresas optam por investir em métodos de desenvolvimento. Existem muitas opções. Algumas empresas que podem arcar com os custos optam por alternativas que oferecem certificações reconhecidas no mercado e adotam métodos tradicionais ou processos oferecidos por consultorias especializadas. Algumas reconhecem que métodos ágeis, por mais jovens que sejam, oferecem uma alternativa viável.

O ensino de XP na Indústria pode ocorrer através de consultorias, onde um treinador é contratado para trabalhar junto com a equipe que vai adotar a metodologia. Nestes casos, o treinador permanece com a equipe até o momento no qual esta pode continuar sozinha, tendo aprendido não só as práticas, mas também como adaptá-las e evoluí-las no seu contexto. Porém, a adoção de XP em uma empresa sempre varia de acordo com a realidade local, podendo ser feita inclusive sem auxílio de um treinador experiente. Muitas vezes, isso acontece após o contato com o método e o subseqüente convencimento dos colegas e da gerência em experimentá-lo.

Em seu trabalho de mestrado, Vinicius Teles [Tel05] relata um caso de sucesso de adoção de Programação eXtrema como método em sua empresa no Brasil. Neste caso, parte de um sistema comercial foi construído durante 14 meses por quatro desenvolvedores experientes, usando as práticas e valores de XP e plataforma a Java J2EE. Tiveram o auxílio de um dos sócios da empresa como treinador. O cliente era um consórcio de empresas que ganhou uma concorrência pública e aceitou um contrato de escopo negociável para o projeto. Entre todas as práticas, somente a de testes automatizados não foi adotada de maneira eficiente. Programação pareada obteve resistência dos desenvolvedores no início do projeto. Porém, após 3 iterações, onde cada iteração durava duas semanas, os desenvolvedores concordaram em adotar todas práticas de XP, ela foi aceita e mantida. A prática de testes automatizados não foi efetiva, sendo que cada release apresentou uma média de 10 defeitos por iteração. A falha foi amortizada pelo trabalho de um analista de testes que identificava e apontava falhas após cada release. O estudo conclui que XP foi aplicada com sucesso, porém não pôde apontar se este caso foi mais eficaz do que seria usando outros métodos, pois o projeto demorou mais tempo e custou mais caro do que o previsto inicialmente. Isto se justificou pelo surgimento de 
muitas novas funcionalidades e mudanças conceituais ao longo do desenvolvimento, quando releases eram apresentados aos clientes. O resultado foi uma grande mudança no escopo da aplicação devido ao aprendizado dos clientes ao longo do projeto. Ressaltou-se porém que os clientes ficaram satisfeitos com o sistema no final do processo. Este, ao ser colocado em produção (o sistema seria utilizado de maneira sazonal, anualmente), apresentou somente 3 defeitos, sendo que o primeiro defeito só foi encontrado quatro meses e meio após o sistema começar a ser utilizado. Nota-se que feedback veloz é essencial para ajustar devidamente o escopo do projeto e obter satisfação dos clientes e que o uso de refatoração é importante para evoluir o design simples.

Em uma experiência semelhante, Pelrine [Pel00] relata um caso de sucesso no qual uma empresa de consultoria na Suiça também participou de uma concorrência e teve que adaptar XP a um contrato de preço fixo. O autor nota que este tipo de contrato envolve alto risco devido a mudanças não previstas de escopo. Observa que, por ser mais flexível, XP pode ser uma boa opção mesmo nesse caso e por isso resolveram adotá-la. O cliente era do ramo farmacêutico. Concordou em usar XP pois não estava satisfeito com a qualidade do software que obtinha de fornecedores externos até então. A análise de requisitos foi feita como um jogo do planejamento, o que permitiu aos desenvolvedores estimar o tempo envolvido com o trabalho e especificar um preço para a concorrência. O resultado foi que XP se mostrou tão ágil que a equipe de desenvolvimento foi até forçada a tirar férias enquanto o cliente obtinha tempo para poder validar um release. O desenvolvimento utilizou a linguagem Smalltalk. Todas as práticas de XP foram seguidas à risca. Porém, devido à resistência da gerência, programação pareada foi adotada em pouco menos de $50 \%$ da produção de código. A equipe era de apenas um desenvolvedor e este envolvia outro para revisões de código, tentando fazer programação pareada de "guerrilha". Quando isso não era possível, o desenvolvedor pareava com o cliente. Ele ressaltou que o uso de Smalltalk foi importante, pois a linguagem permitiu o desenvolvimento de uma metáfora comum e a participação efetiva do cliente, que chegou a programar testes. O projeto foi um sucesso, sendo entregue com o custo previsto antes da data final estimada.

Deias et al. [DMM02] relatam sua experiência de adotar XP em uma empresa especializada no desenvolvimento de portais complexos para clientes externos na Itália. A empresa utilizava ferramentas e processos do RUP ${ }^{1}$ e procurava obter uma certificação ISO 9001 de qualidade para o seu processo de desenvolvimento quando optou por adotar XP. Durante 2 anos, experimentaram a metodologia em dois projetos pilotos para melhorar a qualidade do software produzido e reduzir problemas com a documentação, muito grande e freqüentemente desatualizada, gerada pelos seus processos. A implantação de XP começou com entrevistas com funcionários de diversos departamentos. Estes deveriam relatar problemas que estavam enfrentando e então participar de discussões sobre as práticas de XP e como elas poderiam ajudar. Houve resistência principalmente das áreas de marketing e recursos humanos, e em especial dos funcionários responsáveis pelo fechamento de negócios. Eles não sabiam como poderiam vender contratos de escopo negociável a clientes acostumados com o escopo, o custo e data de um projeto sempre fixos. Funcionários da área de RH tinham medo da prática

\footnotetext{
${ }^{1}$ Rational Unified Process [Kru03].
} 
do cliente sempre presente por achar que desta maneira iriam expor o funcionamento interno da empresa, criando visibilidade demais. Durante os dois projetos pilotos, equipes de 6 a 7 desenvolvedores trabalharam durante 3 meses com o cliente sendo representado pelo diretor do laboratório de $\mathrm{P} \& \mathrm{D}$. Cinco pessoas da equipe tinham menos de 2 anos de experiência com programação. O primeiro projeto foi desenvolvido em $\mathrm{C}++$ e as práticas de jogo do planejamento e padrão de codificação não foram adotadas. O planejamento seguiu práticas sugeridas pelo RUP, como diagramas de Gantt. O diagrama de Gantt é um gráfico usado para ilustrar o avanço das diferentes etapas de um projeto.

O segundo projeto foi desenvolvido em Java, seguindo todas as práticas de XP, inclusive iterações de duas semanas, sessões de desenvolvimento de meia hora e releases a cada duas iterações. Os autores relatam que adotar XP parcialmente não foi satisfatório, que misturar técnicas de planejamento do RUP não foi eficiente, e que perceberam os benefícios da sinergia entre as práticas somente ao adotar XP como um todo. Eles ressaltam dificuldades com refatoração e com o uso de metáfora devido à inexperiência da maioria dos desenvolvedores. Isso também fez com que o treinador tivesse um papel importante durante jogos do planejamento incentivando a participação de pessoas menos experientes.

Em seu segundo piloto, os autores notam que o jogo do planejamento é mais eficiente do que planejamento RUP e melhora a percepção da equipe quanto ao real andamento do projeto, aumentando o nível de motivação dos desenvolvedores. Eles ressaltam as dificuldades sofridas pela inexperiência da equipe e resistência política devido à capacidade de XP de nivelar o conhecimento de programadores em um ambiente no qual a progressão de carreira projetava programadores a analistas de requisitos e depois a gerentes de projeto. O estudo relata a importância de adotar XP como um todo e de utilizar um cliente proxy ativo quando a presença de clientes dentro da empresa não é desejável. Conclui dizendo que XP é mais fácil de adaptar a um arcabouço ISO 9001, sendo mais ágil do que outros métodos para obter este tipo de certificação. Atualmente, 15 desenvolvedores trabalham na empresa utilizando XP.

Já Howard [How03] relata um caso de adoção similar, em uma empresa americana que utilizava o modelo em cascata. Uma equipe liderada por um desenvolvedor com pouca experiência prévia com XP aproveitou a insatisfação de um cliente, que ameaçou cancelar o contrato da segunda fase de um projeto devido ao alto custo e tempo levado na primeira fase, para convencer a gerência a experimentar XP. O autor aponta muitas dificuldades neste contexto, onde uma equipe de 12 pessoas, algumas que seguiam o processo do modelo em cascata, 3 delas trabalhando offshore na Índia, enfrentou problemas para aprender as práticas de XP. A equipe conviveu com falhas de comunicação e resistência aos testes, integração contínua e ritmo sustentável. O autor conclui apontando que mesmo assim o projeto foi eficaz e satisfez o cliente, principalmente devido aos releases freqüentes e à possibilidade de re-planejamento. Ele aponta que, após algum tempo, a equipe que trabalhava no mesmo local conseguiu estabelecer um bom ritmo de desenvolvimento que se adaptava bem a mudanças. Conclui que, em uma próxima oportunidade, tentariam investir mais no aprendizado da equipe e na melhor integração com o resto da empresa. 
Em uma comparação entre dois releases de um mesmo projeto, Layman et al. [LWC04a] falam da experiência da empresa aérea Sabre nos Estados Unidos. No primeiro release, o modelo de cascata era utilizado com algumas práticas de XP como integração contínua. No segundo, XP foi adotada completamente. A equipe foi uma das primeiras a adotar a metodologia dentro da empresa e contava com 10 desenvolvedores. O programa sendo desenvolvido atendia às necessidades de aproximadamente 30 clientes externos. Os autores notam que a equipe já tinha características ágeis e que contava com apoio da gerência e da organização para adotar XP. O estudo mostra um aumento de $50 \%$ em produtividade, $65 \%$ em qualidade antes do release final e $35 \%$ em qualidade após o release final. A única prática que sofreu resistência da equipe foi programação pareada. Desenvolvedores não viam valor em aplicá-la em tarefas consideradas simples. A prática foi utilizada somente $50 \%$ do tempo. Atualmente 200 desenvolvedores da Sabre utilizam XP, distribuídos em mais de 30 equipes.

Fuqua e Hammer [FH03] relatam um caso típico onde uma equipe XP teve que se adaptar a muitas mudanças. Era um projeto interno em uma empresa que desenvolvia sistemas de segurança para a Internet nos EUA. Uma equipe de 2 a 4 desenvolvedores teve que lidar com mudanças de treinador, de clientes, da própia equipe, de requisitos e até com a parada e retomada do projeto. Ela contava com 30 clientes internos e trabalhou cerca de 40 iterações de duas semanas em 252 histórias. Os autores ressaltam a importância de não tentar descobrir todas as histórias previamente, durante uma fase de planejamento inicial identificaram menos de $50 \%$ das histórias; e também não ter medo de descartar histórias, no final $8 \%$ foram descartadas. Relatam também a importância de usar um Wiki para lidar com o grande número de clientes e pequenas histórias. Neste Wiki, as estimativas de tempo para completar blocos de histórias satisfaziam os clientes e eram usadas pela gerência quando surgia necessidade de repriorizações.

Quando surgiram novos clientes, os autores relatam que o design simples facilitou a adaptação do projeto aos novos requisitos. Quando a mesma equipe teve que assumir um outro projeto em paralelo, mostram que bastou incorporar histórias de ambos projetos em suas iterações para lidar com a nova responsabilidade. Parar e retomar o projeto foi simples, bastando para isso parar após o final de uma iteração. Eles ressaltam a importância da documentação de histórias no Wiki e propõem que uma semana de refatoração é uma excelente maneira de retomar um projeto com rapidez. Quando a equipe teve que crescer, relatam que foi importante escolher desenvolvedores motivados não importando tanto suas habilidades técnicas. Mostram também como programação pareada foi importante para que os novos desenvolvedores aprendessem XP e já contribuíssem efetivamente no seu primeiro dia de trabalho. Com a saída de um desenvolvedor, perceberam que a prática de propriedade coletiva de código não tinha sido tão eficiente, pois tiveram dificuldades de dar continuidade ao desenvolvimento de certas partes do sistema.

A saída do treinador, no entanto, foi tranqüila; outro desenvolvedor assumiu as responsabilidades sem grandes problemas, mostrando que o trabalho do treinador foi realmente bem feito. Concluem sua análise ressaltando a importância de um bom treinador, uma equipe motivada, e muita programação 
pareada para o sucesso deste projeto repleto de mudanças.

O caso de uma empresa Italiana de integração de sistemas desenvolvendo uma aplicação de acompanhamento de portfólios para investidores de um banco privado relatado por Bossi [Bos03b], é exemplar. Nele, o banco aceitou um contrato de escopo negociável e disponibilizou um cliente proxy para trabalhar durante 3 dias por semana em conjunto com uma equipe de 4 a 6 desenvolvedores. Além do cliente proxy e dos desenvolvedores, um treinador e um gerente de negócios da empresa relacionavam-se com um gerente do banco, que tomava as últimas decisões sobre mudanças de escopo do projeto. Membros da equipe revezavam-se no papel de acompanhador gastando 15 minutos diários para realizar medições. Isso garantia feedback rápido. Todas as práticas foram seguidas à risca e além delas a equipe se beneficiou de um Wiki e planilhas de acompanhamento. Ela evoluiu o seu uso de XP com novas práticas como Papos-em-pé aliados a diários no Wiki, que relatavam os resultados de cada sessão de programação pareada.

Estas práticas, em conjunto com retrospectivas e tempo dedicado a pesquisa, garantiam uma cultura de aprendizado contínuo que está explícita na evolução das estimativas: em média a equipe subestimou suas histórias em 15,68\%, mas nos últimos 3 meses esse erro caiu para 0,61\%. Bossi relata que o cliente ficou muito satisfeito com o contrato de escopo negociável quando percebeu que um requisito de obter informações em tempo-real não poderia ser desenvolvido devido a limitações de outro de seus fornecedores. Ele pode adaptar o plano, satisfazendo-se com informações atualizadas a cada 15 segundos.

O projeto durou 10 meses e meio e contou com 26 iterações. 12.393 linhas de código executável foram produzidas num sistema com 297 classes, 886 testes de unidade e 161 testes de aceitação. Somente 14 defeitos foram encontrados, sendo que apenas 3 após o sistema entrar em produção. Considerando seu relato um sucesso total, o autor nota que o jogo do planejamento, acompanhamento efetivo, retrospectivas e a presença constante do cliente foram essenciais para obter confiança mútua e alterar devidamente o escopo do projeto, garantindo assim o seu êxito.

$\mathrm{Na}$ próxima seção descreveremos em detalhes nossa experiência ensinando e adaptando XP em uma empresa start-up no Brasil [FKT05].

\subsection{Paggo - uma start-up brasileira adota XP}

Aprender a adaptar-se a mudanças é especialmente importante em uma economia em desenvolvimento, como a Brasileira, na qual empresas abrem e fecham rapidamente. Além disso, flutuações econômicas são freqüentes, bons desenvolvedores são difíceis de encontrar e muitos negócios sobrevivem reciclando estagiários constantemente. Salários baixos são a norma e refletem uma força de trabalho desqualificada e uma cultura de contínua troca de funcionários. Ferramentas e arcabouços tem pouca documentação em português. Desenvolver software de alta qualidade, a tempo e no orçamento é diferencial estratégico para uma empresa sobreviver neste contexto. Para tanto, ajudamos uma empresa star-up, a Paggo, a adotar XP como metodologia. 
Ela entrava no negócio altamente competitivo de cartões de crédito. O sistema a ser desenvolvido era altamente inovador, usando tecnologias como Java J2EE e J2ME e arcabouços livres e de código aberto como VRaptor, JBoss e Hibernate. O projeto tinha muitos aspectos, desde a gerência de transações de crédito com requisitos de alto desempenho até tecnologia móvel embarcada em telefones celulares. Um portal dinâmico onde clientes poderiam pedir cartões e verificar seu balanço mensal seria a parte mais simples do sistema.

A Paggo apostava em um modelo de negócios baseado em novas tecnologias e na utilização de um método ágil para conseguir ter software funcional rapidamente. Isso reduziria o tempo de entrada no mercado com o objetivo de obter mais investimentos. A Figura 3.12 mostra quatro desenvolvedores pareando no escritório inicial da Paggo.

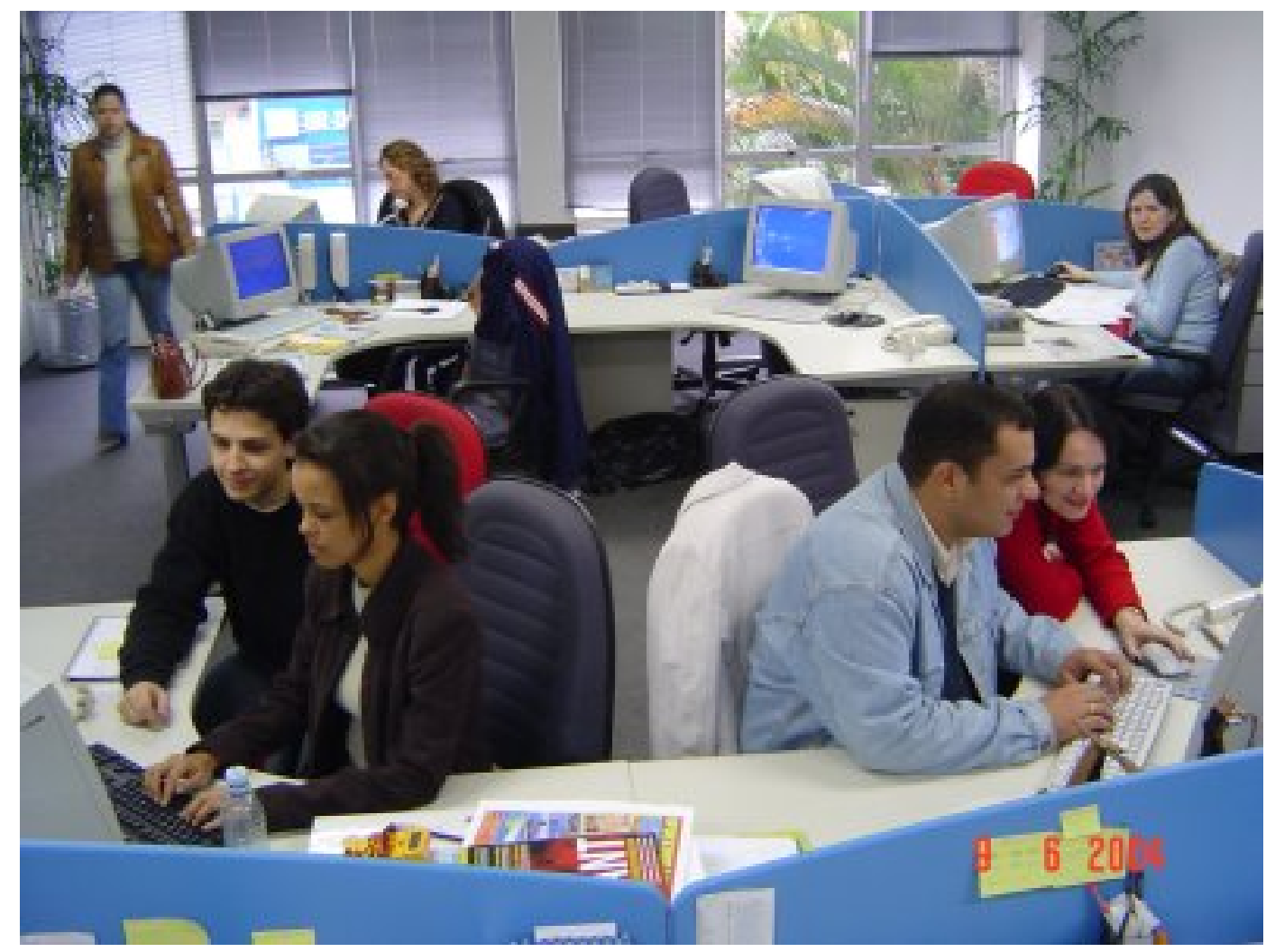

Figura 3.12: Dois pares trabalhando no espaço aberto e informativo da Paggo

Desde o início, muitos desafios se apresentaram. O mais difícil foi lidar com o aspecto heterogêneo da equipe, composta de desenvolvedores com diferentes habilidades: de estagiários com pouca ou nenhuma experiência programando a seniores acostumados com sua própria maneira de programar. Além disso, o treinador não poderia estar presente em tempo integral devido ao orçamento limitado. Mesmo assim, tínhamos esperança já que adotar XP tinha sido sugestão de um membro da equipe e todos haviam aceitado o desafio. 
Nosso objetivo principal era ter uma equipe proficiente em XP e pronta para trabalhar independente do treinador após alguns meses. Nestes, além de treinar a equipe nas práticas de programação extrema, também ensinaríamos tecnologias e até mesmo aspectos de Orientação a Objetos.

O autor atuava como meta-treinador, o papel que um consultor externo exerce durante o período no qual ensina XP à uma organização, presente em tempo parcial, comparecendo à empresa pelo menos 3 dias por semana. O papel do cliente era desempenhado por um dos fundadores da empresa, Cícero Torteli, presente durante todo o tempo. Outro consultor em tempo parcial ajudou a treinar a equipe durante os primeiros meses no uso das tecnologias necessárias. O papel de acompanhadora era realizado por uma estagiária que se sentiu muito motivada ao exercê-lo. A Figura 3.13 mostra a acompanhadora da Paggo em ação.

No início do quarto mês, mais dois desenvolvedores foram contratados. Eles contribuíram para código colocado em produção logo na primeira semana de trabalho, devido à prática efetiva de programação pareada e o fato da equipe já estar confortável com XP. Além disso, um deles tinha participado do Laboratório de Programação eXtrema no IME/USP.

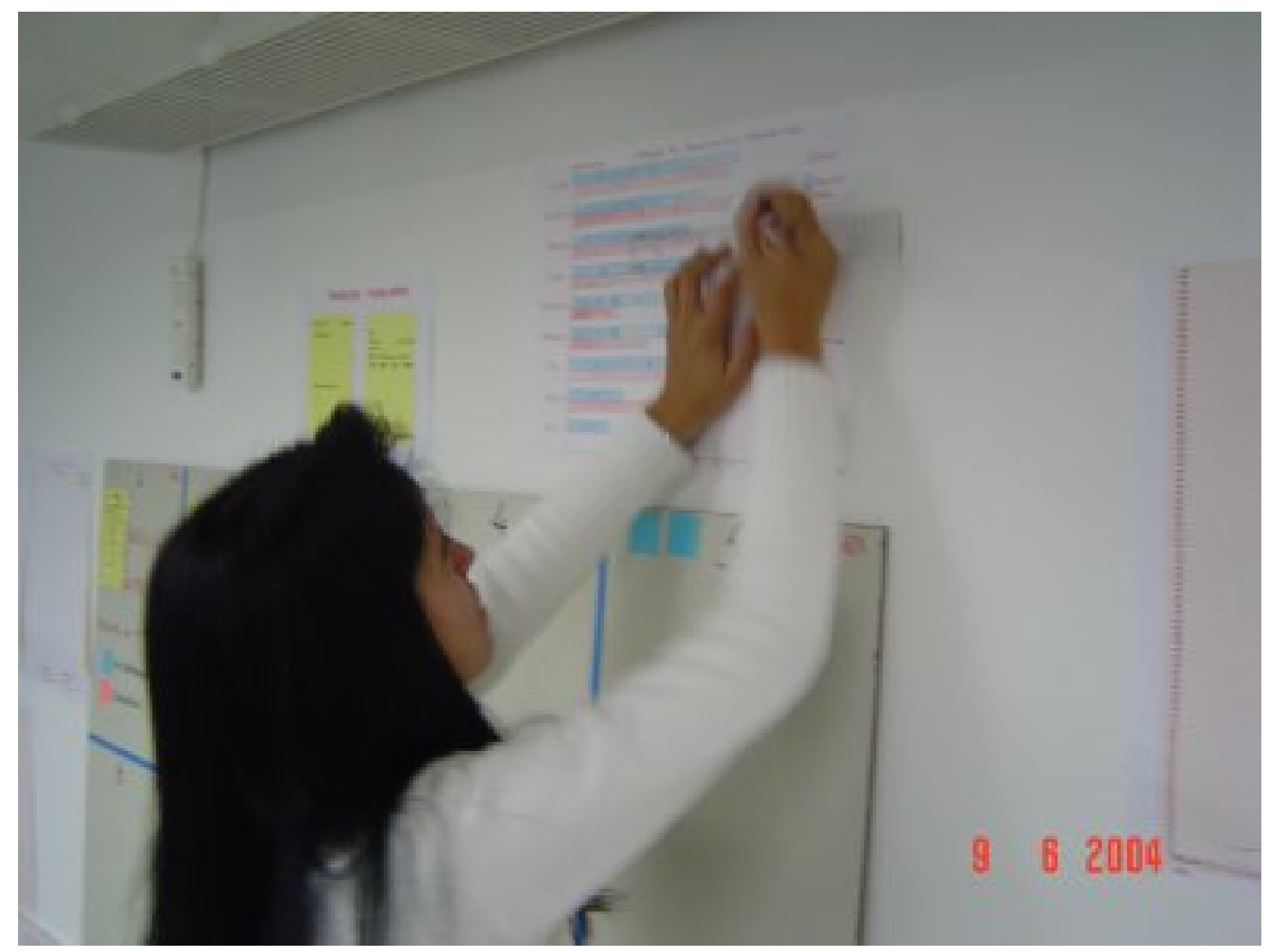

Figura 3.13: Acompanhadora atualizando medidas nos radiadores de informação da Paggo

O maior desafio seria lidar com a heterogeneidade da equipe. Como incentivar todos a seguirem $\mathrm{XP}$ e ao mesmo tempo lidar com as dificuldades individuais? Mesmo tendo toda equipe dedicada a 
aprender XP, os desenvolvedores mais experientes resistiam a algumas práticas como programação pareada, propriedade coletiva do código e integração contínua. Em especial, o desenvolvedor mais velho da equipe se mostrou altamente resistente a mudar seus hábitos. Além disso, muitos não tinham as habilidades necessárias para praticar testes automatizados, design simples e refatoração.

Decidimos ensinar XP com todas práticas desde o início, mesmo cientes de que demoraríamos algum tempo para alcançar níveis maduros e aceitáveis em algumas delas. Durante 6 meses, fizemos 12 releases em sua maioria desenvolvidos em iterações de duas semanas. Produzimos 4 aplicações, implementando com sucesso 269 histórias de um total de 340 escritas pelo cliente. Destas, 42 foram descartadas ou consideradas desnecessárias. De um ponto de vista técnico, entregamos $90 \%$ das funcionalidades desejadas, todas testadas e sem defeitos. A Figura 3.14 mostra o radiador de informação de acompanhamento de um release.

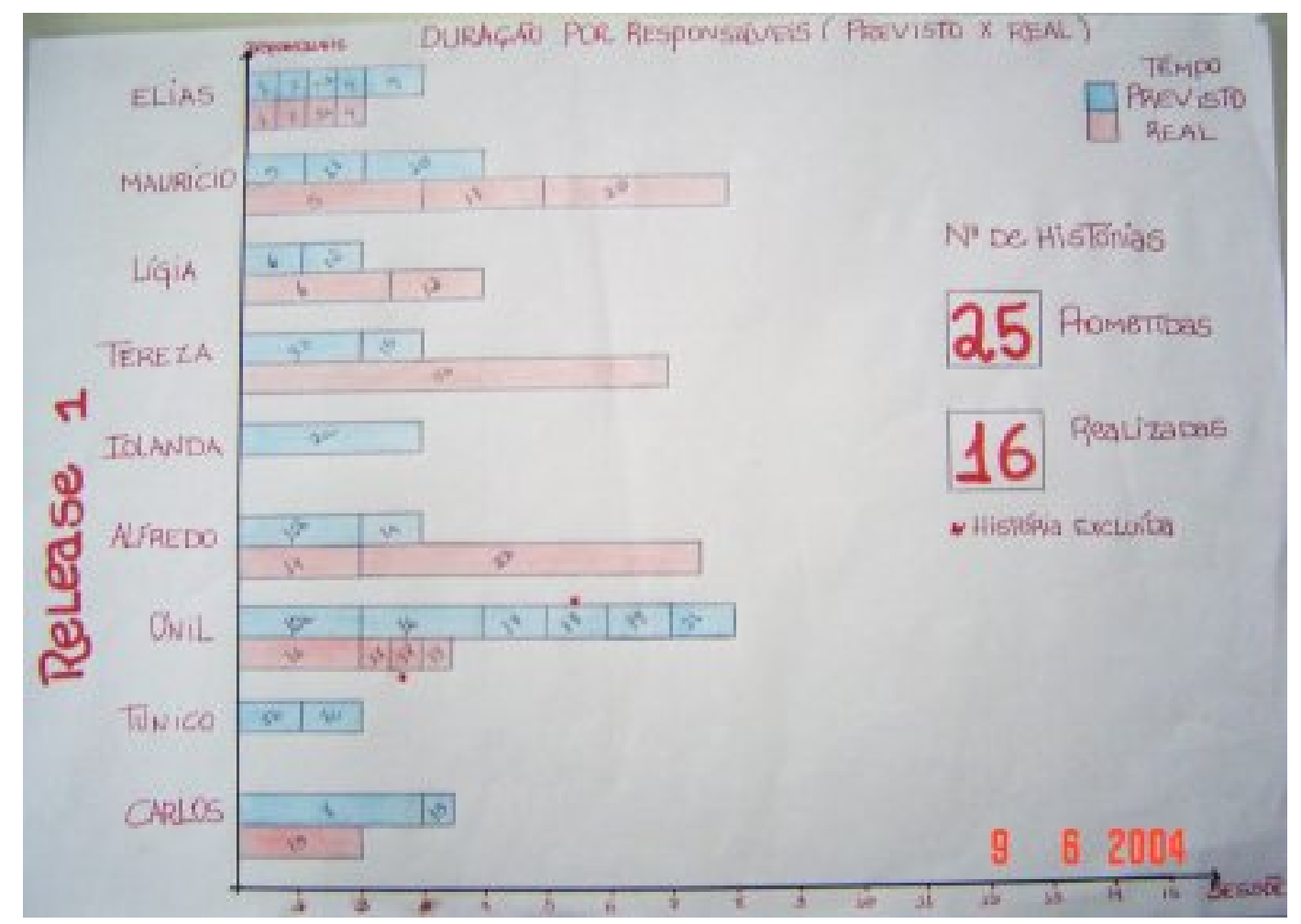

Figura 3.14: Radiador de informação com acompanhamento de um dos primeiros releases de sistemas da Paggo compara o tempo estimado e o tempo real gasto em cada história entregue

Durante os primeiros dois meses, exploramos todas as práticas de XP. Foi necessária muita calma na adoção de práticas que demandavam mais conhecimentos técnicos como desenvolvimento dirigido por testes, integração contínua e refatorações. Nos quatro meses seguintes treinamos a equipe em padrões de projeto orientado a objetos e nos arcabouços de código aberto sendo utilizados. Ao mesmo tempo em que a equipe ficou mais confortável com padrões e técnicas mais avançadas de orientação a objetos, as práticas de testes e refatoração evoluíram. 
Após participar de uma conferência sobre XP, o XP Brasil 2004, o treinador introduziu algumas novas práticas, sendo Retrospectivas a mais importante e mais eficaz. Usávamos um quadro de histórias para acompanhar o progresso do projeto, onde passamos a coletar informações diariamente para usar em retrospectivas freqüentes. A Figura 3.15 mostra o quadro. Além disso, a equipe contava com um espaço aberto e fazia uso de vários radiadores de informação. A Figura 3.16 mostra um radiador de informação utilizado com medidas da base de código.

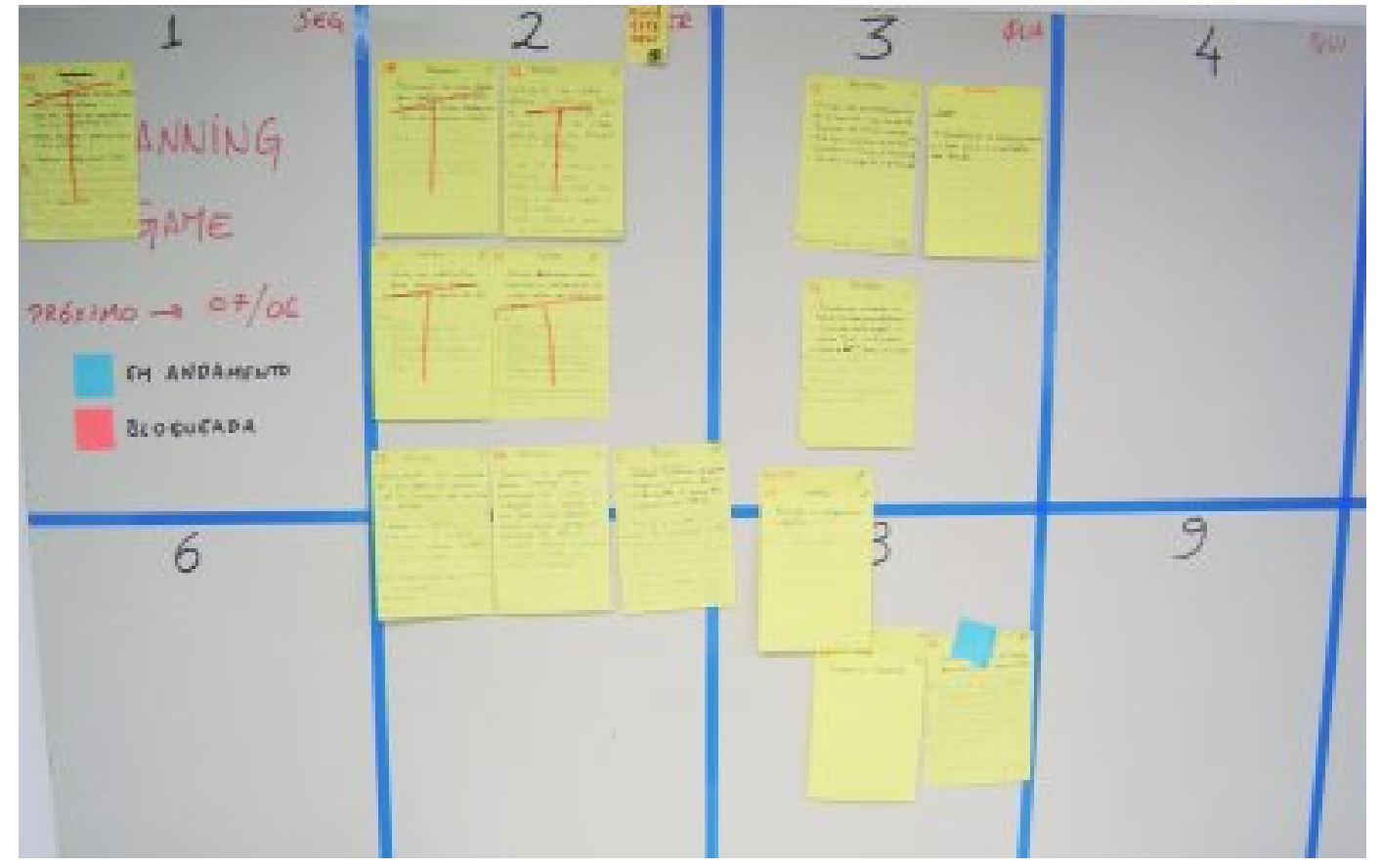

Figura 3.15: Quadro de histórias para acompanhar o andamento de um release na Paggo

A presença do cliente foi muito importante, tanto para repriorizar histórias quanto para motivar a equipe na transição para XP. O cliente era também o proprietário da empresa e apoiou completamente a adoção da metodologia. Sua participação foi essencial no início do projeto, onde contribuía até mesmo nos papos-em-pé, verificando o andamento da iteração e adaptando o escopo dos primeiros releases constantemente devido a estimativas erradas em razão da pouca prática da equipe. Seu papel também se mostrou essencial quando chegamos à conclusão de que era melhor que o desenvolvedor mais resistente a adoção de XP deixasse a equipe. Tomar esta difícil decisão foi importante para manter a equipe engajada no aprendizado do método.

No final do quinto mês, a empresa teve que cortar custos pois ainda não tinha garantido novos investimentos. Nessa época, o treinador entrou em acordo com o cliente para dedicar seu último mês de trabalho, garantindo que a equipe poderia continuar fazendo XP sem sua presença, o que aconteceu sem dificuldades.

Desde então a empresa obteve novos investimentos e triplicou sua equipe que já desenvolveu mais 


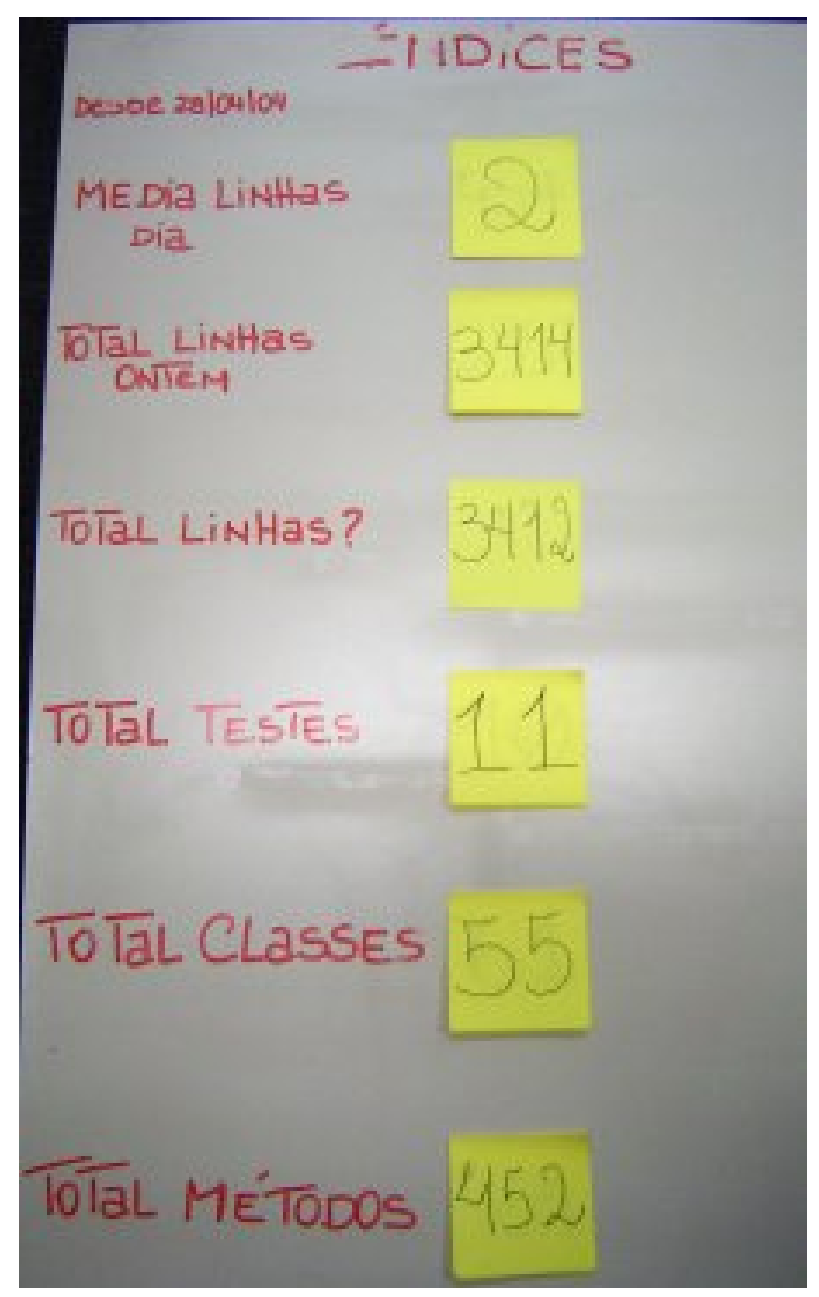

Figura 3.16: Radiador de informação mostrando evolução da base de código de um dos sistemas da Paggo.

de 260 mil linhas de código de qualidade. Do ponto de vista do negócio, o projeto foi considerado um sucesso total. Hoje a Paggo se estabelece como líder no mercado brasileiro, oferecendo seu produto para a operadora de celular Oi. Práticas ágeis são usadas até mesmo em departamentos que não estão envolvidos com programação.

Iremos discutir o papel de meta-treinador e o uso de práticas ágeis em equipes de outras áreas em mais detalhes nos próximos capítulos.

\subsection{Trabalhos relacionados no Governo}

Existem poucos estudos sobre o ensino e adoção de XP dentro de contextos governamentais. Talvez porque muitas vezes instituições governamentais delegam o trabalho de desenvolvimento de software para empresas contratadas por concorrências públicas. Ou então, quando possuem equipes internas de desenvolvimento, estas adotam práticas guiadas por planejamento e documentação típicas 
de ambientes mais burocráticos. Porém, observamos que métodos ágeis podem trazer benefícios mesmo nestes contextos onde mudanças acontecem, mas são implementadas com pouca velocidade e encontram muita resistência dos funcionários que estão acostumados com a burocracia da máquina governamental, que é uma barreira à aceitação de muitos dos princípios de XP.

$\mathrm{O}$ ensino de XP dentro de instituições do governo pode acontecer de diversas maneiras. As iniciativas que observamos surgem através da motivação de alguns indivíduos dentro das equipes de Tecnologia da Informação. Elas ocorrem muitas vezes por vontade própria dessas equipes, sem apoio institucional.

Em um estudo controlado, Wood e Kleb [WK03] relatam um caso onde uma equipe pequena de 2 programadores adotou XP sem problemas em um projeto piloto de missão crítica de um departamento de pesquisa da Nasa. Eles analisaram sua produtividade e a compararam com projetos passados, demonstrando que o uso de XP foi aproximadamente duas vezes mais produtivo. Ambos tinham pouca experiência com XP e aprenderam o método com o apoio da literatura existente.

Alleman e Henderson [AHS03] relatam um caso de adoção parcial de XP onde adaptações tiveram de ser feitas ao acompanhamento do projeto para prover a documentação necessária para a burocracia governamental. Trabalharam no Departamento de Energia de Colorado nos Estados Unidos em um projeto crítico relacionado a armas nucleares. O maior desafio era apresentar o andamento do projeto sob a forma de "valor produzido" a cada período de contabilidade. Isto os fez adaptar o acompanhamento de velocidade do projeto para o formato exigido, introduzindo custos de tempo tanto para o acompanhamento do projeto quanto para criação desta documentação extra. A equipe contava com aproximadamente 100 pessoas e os requisitos eram providenciados por um departamento inteiro responsável apenas por isso. Eles relatam dificuldades relacionadas aos relatórios financeiros, à necessidade de obter certificações $\mathrm{CMMi}^{2}$ nível 4 e também aos requisitos de segurança, que impossibilitaram a equipe de praticar programação pareada e propriedade coletiva do código, nem todos desenvolvedores tinham níveis de acesso de segurança para ver todas as partes do código. Concluem que é possível adaptar XP a este contexto e obter os benefícios das práticas utilizadas em conjunto com técnicas tradicionais para prover a documentação exigida pelos órgãos governamentais.

Goldman et al [GKSY04] relatam um caso no Departamento de Saúde Pública de Illinois, Estados Unidos. Nele a empresa de Yoder providenciou uma equipe para ajudar no desenvolvimento de um arcabouço que agregaria informações sobre dados comuns a aplicações médicas diversas. O objetivo era obter reutilização de código, criando maneiras mais fáceis e rápidas de entregar novas aplicações e compartilhar dados entre programas. A equipe de 10 pessoas utilizou muitas práticas de XP e foi treinada por Yoder que também atuou como arquiteto principal. O departamento utilizava cubículos para seus desenvolvedores. Uma das primeiras coisas que fizeram foi criar um espaço aberto e comunicativo. O autor nota que o espaço aberto acabou criando visibilidade demais e os funcionários do departamento não ficaram confortáveis com a idéia. Críticas surgiram principalmente de outros

\footnotetext{
${ }^{2}$ Capability Maturity Model integration [PWCC95, CKS03].
} 
funcionários do departamento, que ao ouvir conversas e interpretá-las erroneamente reclamavam para a gerência que os desenvolvedores estavam desperdiçando tempo. Ele sugere que teria sido melhor isolar o espaço aberto do resto do departamento. Além disso, nota a importância da prática de programação pareada quando pessoas saiam e entravam no projeto, facilitando a incorporação de novos desenvolvedores que se tornavam produtivos rapidamente. Porém, nem todos desenvolvedores pareavam e algumas soluções individuais eram integradas, com testes e sem comprometer a propriedade coletiva do código, além disso os pares não se revezavam. Ele relata também a importância dos testes como documentação de uso do arcabouço criado e ressalta a facilidade de criar testes de aceitação devido à adoção de Smalltalk. Dificuldades foram encontradas na prática de releases pequenos. Por mais que, internamente, a equipe entregasse releases com freqüência, o departamento não via a necessidade de colocar estes em produção devido à percepção de que seria uma perda de tempo colocar seus funcionários para utilizar um sistema que ainda estava em desenvolvimento. Yoder nota que o maior problema encontrado foi na adoção de histórias. Por não ter acesso aos funcionários que utilizariam o sistema, esta prática não foi adotada e os requisitos foram entregues por analistas do governo. Isso fez com que um dos sistemas desenvolvidos gerasse reclamações dos usuários finais por não ser aquilo que precisavam. O autor conclui que a estrutura política de uma organização governamental foi o maior empecilho para adoção completa de XP.

Na próxima sessão, descrevemos em detalhes nossa experiência de alguns anos tentando implantar XP em um contexto governamental no Brasil.

\subsection{Ministério da Cultura - Desenvolvimento de software no projeto Cultura Digital}

No ínicio de 2005, o autor foi contratado para trabalhar como coordenador de tecnologia no Departamento de Cultura Digital do Ministério da Cultura Brasileiro. O projeto principal deste departamento estava ligado à distribuição de kits multimídia para cerca de 600 Pontos de Cultura espalhados pelo país que seriam treinados no seu uso. Parte do trabalho técnico estava ligado ao desenvolvimento de três portais de suporte a este processo: o Conversê (http://converse. org.br), no qual pessoas ligadas aos pontos poderiam se cadastrar, fazer amigos e conversar em uma rede social; o Mapsys (http://culturadigital.org.br/tiki-index.php?page=MapSys), um sistema de gestão colaborativa da rede de pontos, no qual dados burocráticos e administrativos eram armazenados, atualizados e geo-referenciados; e o Estúdio Livre (http://estudiolivre.org), plataforma na qual informações sobre o uso de software livre e de código aberto para produção multimídia seriam agregadas e artefatos digitais criados por uma comunidade seriam disponibilizados em um acervo.

Inicialmente, a equipe técnica dedicada ao desenvolvimento destas plataformas contava com apenas três desenvolvedores, que também se dedicavam a outros aspectos do projeto. Em conjunto com outros membros do departamento começamos a levantar os requisitos que levariam à criação dos três portais. A equipe da Cultura Digital era composta por mais de 80 pessoas de diferentes áreas: 
programadores, artistas, designers, músicos, ativistas, políticos, voluntários, pesquisadores, bolsistas, estagiários e até funcionários contratados entre membros de pontos de cultura. Esta heterogeneidade mostrou-se excelente para melhorar o lado humano do projeto e propiciar momentos muito criativos. Dialogamos com os políticos responsáveis pelo projeto, com pessoas dos Pontos de Cultura que utilizariam os sistemas e também conceituamos a ação da Cultura Digital baseado na pesquisa que desempenhávamos.

Este período de planejamento se refletiu em outras equipes do departamento e conceituou o que viria a ser chamado de programa de implantação de Cultura Digital nos Pontos de Cultura. Inicialmente, equipes de pesquisa deveriam se familiarizar com software livre e de código aberto para produção multimídia e documentar esta pesquisa, criando metodologias de ensino das ferramentas. As necessidades destas equipes criaram a demanda de desenvolvimento do Estúdio Livre. Equipes de mapeamento iriam visitar os Pontos de Cultura para conhecer melhor sua realidade local, fornecendo informações importantes para futuras ações e também para o trabalho dos pesquisadores. Das necessidades destas equipes surgiu a demanda pelo MapSys. Além disso, todo o trabalho deveria ser feito em um processo de gestão compartilhada constante de consulta a pessoas dos Pontos de Cultura; incentivando a criação do Conversê.

Durante os primeiros quatro meses de trabalho, esboços dos portais foram produzidos e alguns spykes colocados em produção para avaliação de usuários dos pontos de cultura e da equipe. Este desenvolvimento aconteceu de maneira bastante orgânica, contando com um Wiki para organização de demandas e idéias. No quinto mês, contratamos mais dois desenvolvedores com pouca experiência de mercado e resolvemos iniciar um processo de adoção de XP. Durante uma semana, juntamos em um mesmo local os desenvolvedores e os pesquisadores que iriam atuar como clientes proxy, que estavam distribuídos em outras regiões do país. Neste encontro, conseguimos realizar um jogo do planejamento e, de maneira ágil, colocar em produção a primeira versão de cada sistema. Além disso, geramos os documentos exigidos pela burocracia governamental. De todas as práticas de XP, testes e refatorações não foram adotadas devido à inexperiência da equipe, a falta de tempo para o aprendizado e a adaptação de programas livres e de código aberto existentes, cujas comunidades não adotavam métodos ágeis. Isso implicou também que um ritmo sustentável não fosse adotado: nesta semana de iterações diárias, que culminaram em 3 releases, trabalhamos mais do que 10 horas por dia. Mesmo assim, a proximidade dos clientes proxy ajudou para que os sistemas desenvolvidos tivessem as funcionalidades mais importantes para serem valiosos em produção (foram colocados em produção no final da semana) e para que uma metáfora comum fosse construída. A Figura 3.17 mostra um cliente proxy pareando com um desenvolvedor na nossa primeira semana extrema.

Após este início turbulento, adotamos um processo mais cuidadoso de ensino de XP. Resolvemos começar a adotar as práticas aos poucos, e o autor passou a atuar como treinador. Mas, devido a outras responsabilidades, (como o processo de licitação dos kits que durou mais de um ano devido à burocracia governamental) não poderia estar presente o tempo todo. 


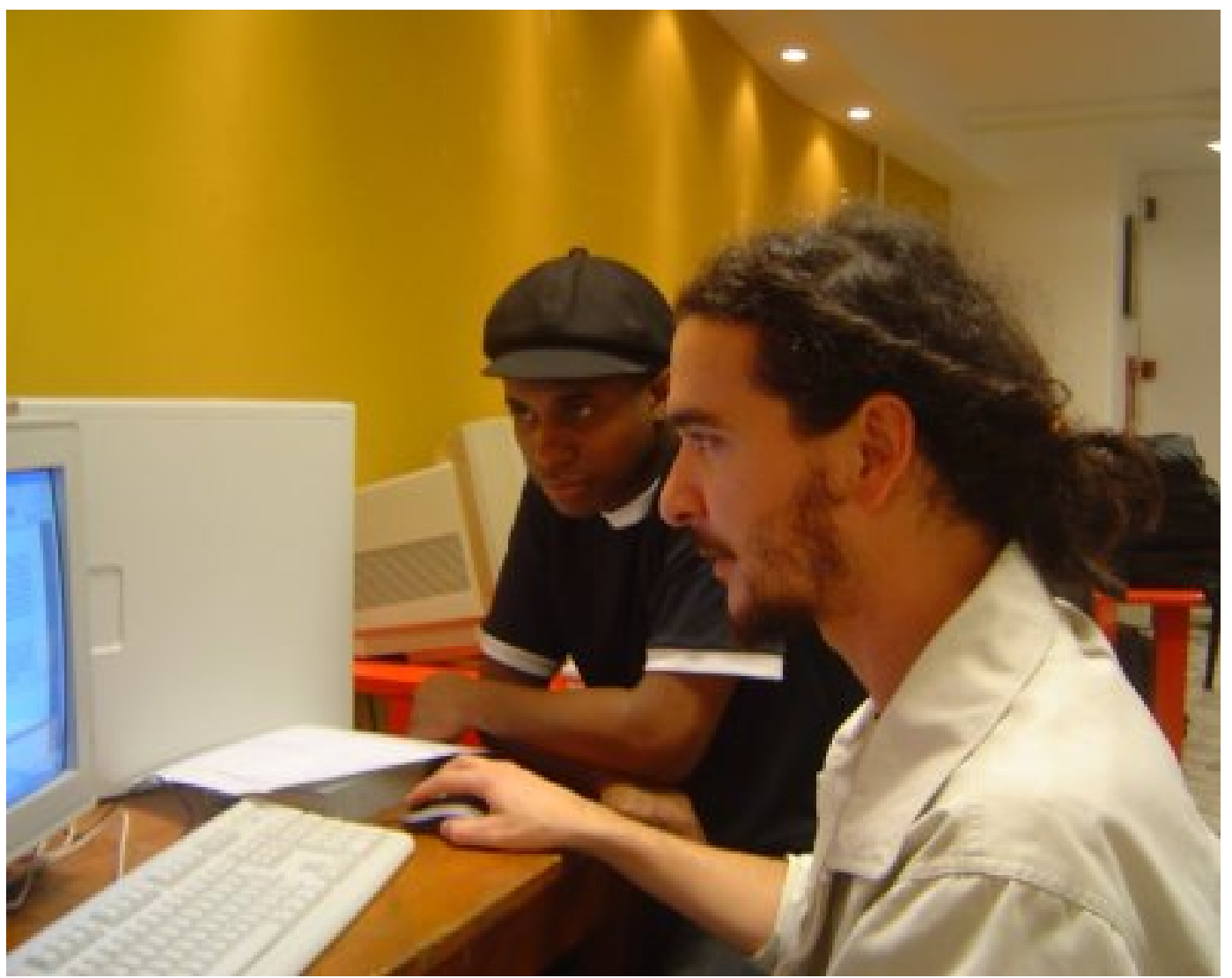

Figura 3.17: Cliente proxy pareando com um desenvolvedor na primeira semana extrema da Cultura Digital

Optamos por desenvolver todos os sistemas como adaptações de sistemas livres existentes: para o Conversê adaptamos o Drupal; para o Estúdio Livre adaptamos o TikiWiki; e para o MapSys fomos corajosos, refatorando ou descartando o código do primeiro release da semana extrema e adaptando o TikiWiki para criar o segundo.

Inicialmente, adotamos o jogo do planejamento onde alguns clientes proxy criavam histórias e atuavam em conjunto para negociar prioridades entre os três sistemas que estavam sendo produzidos. Adotamos também iterações semanais, algumas vezes dedicando uma semana somente a um sistema e depois revezando entre os sistemas. Após dois meses, novos releases dos três sistemas foram colocados em produção. Eles começaram a ser utilizados por mais usuários nos pontos de cultura e pela equipe inteira do departamento que atuava localmente em oficinas e mapeamentos, viagens de visita aos pontos para reconhecer seu contexto local.

Durante estes dois meses, adotamos também as práticas de espaço aberto e comunicativo, programação pareada, integração contínua e papos-em-pé. Tivemos problemas com o espaço aberto, pois a equipe do departamento era multi-disciplinar e, algumas vezes, os programadores não conseguiam se concentrar em um ambiente altamente caótico, no qual artistas regularmente faziam muito barulho, 
o ápice da crise foi uma gravação de um conjunto de percussão. Além disso, programação pareada não era utilizada $100 \%$ do tempo. Em algumas tarefas complexas, os desenvolvedores com mais experiência trabalhavam sozinhos, em tarefas simples os novos estagiários trabalhavam sozinhos. Era complicado colaborar com membros das equipes distribuídos geograficamente. De qualquer forma, programação pareada se mostrou valiosa para treinar os programadores menos experientes nas plataformas livres que estávamos aprimorando, especialmente a estagiária que entrou para a equipe nos últimos meses. A prática de integração contínua se mostrou fácil de adotar, pois seu uso é comum em comunidades de software livre e de código aberto, nas quais nossos desenvolvedores tinham atuado previamente. A prática de papo-em-pé mostrou-se eficiente para melhorar a comunicação entre a equipe.

Ainda neste primeiro ano, conseguimos realizar mais um release de cada sistema, sendo que em média utilizávamos 8 iterações de uma semana para produzir cada um. Por mais que os usuários finais dos sistemas estivessem satisfeitos com o progresso, os políticos responsáveis pelo financiamento do projeto não conseguiam acompanhar este ritmo de entregas e não se comunicavam com a equipe. Reuniam-se poucas vezes com representantes do projeto que tentavam mostrar o valor dos sistemas sendo desenvolvidos. Durante este tempo, duas demandas foram feitas pelos políticos: a implementação de logotipos governamentais em todos sistemas e a integração do MapSys com um sistema legado de controle de convênios do Ministério, chamado "Sistema de Gerenciamento de Editais" (SGE).

Observamos a extrema importância de ter clientes proxy dentro de nossa equipe em contato com usuários finais dos sistemas nos pontos de cultura para guiar o planejamento. Foi somente através do seu trabalho que conseguimos balancear as necessidades políticas com as reais necessidades dos usuários. A Figura 3.18 mostra um jogo do planejamento com um cliente proxy da Cultura Digital.

A integração com o sistema SGE mostrou-se um exemplo claro da inabilidade do sistema público de atuar com agilidade. Entre a priorização desta demanda pelo Secretário do departamento e a primeira reunião com a equipe de desenvolvimento do sistema legado do Ministério 4 meses se passaram. Durante este tempo, nossa equipe desenvolveu melhorias nos outros sistemas e priorizou o desenvolvimento do Conversê e do Estúdio Livre. Após essa reunião, ficou decidido que iríamos desenvolver um módulo de exportação de dados diretamente no sistema SGE, porém só conseguimos obter uma cópia do código fonte cinco meses depois.

Com o código fonte, conseguimos produzir o módulo de exportação em apenas duas semanas, porém os funcionários do Ministério não o colocaram em produção até hoje. Observamos a grande diferença de agilidade de uma equipe que adota XP e de outra que segue processos burocráticos e acaba perdendo velocidade por causa destes.

No início do segundo ano, encontramos nossas maiores dificuldades. O Secretário estava insatisfeito com aspectos do projeto e resolveu esperar para renovar o contrato de toda a equipe, que incluia nossa equipe de desenvolvimento. Esta reagiu de forma ágil: para lidar com o gap salarial traba- 


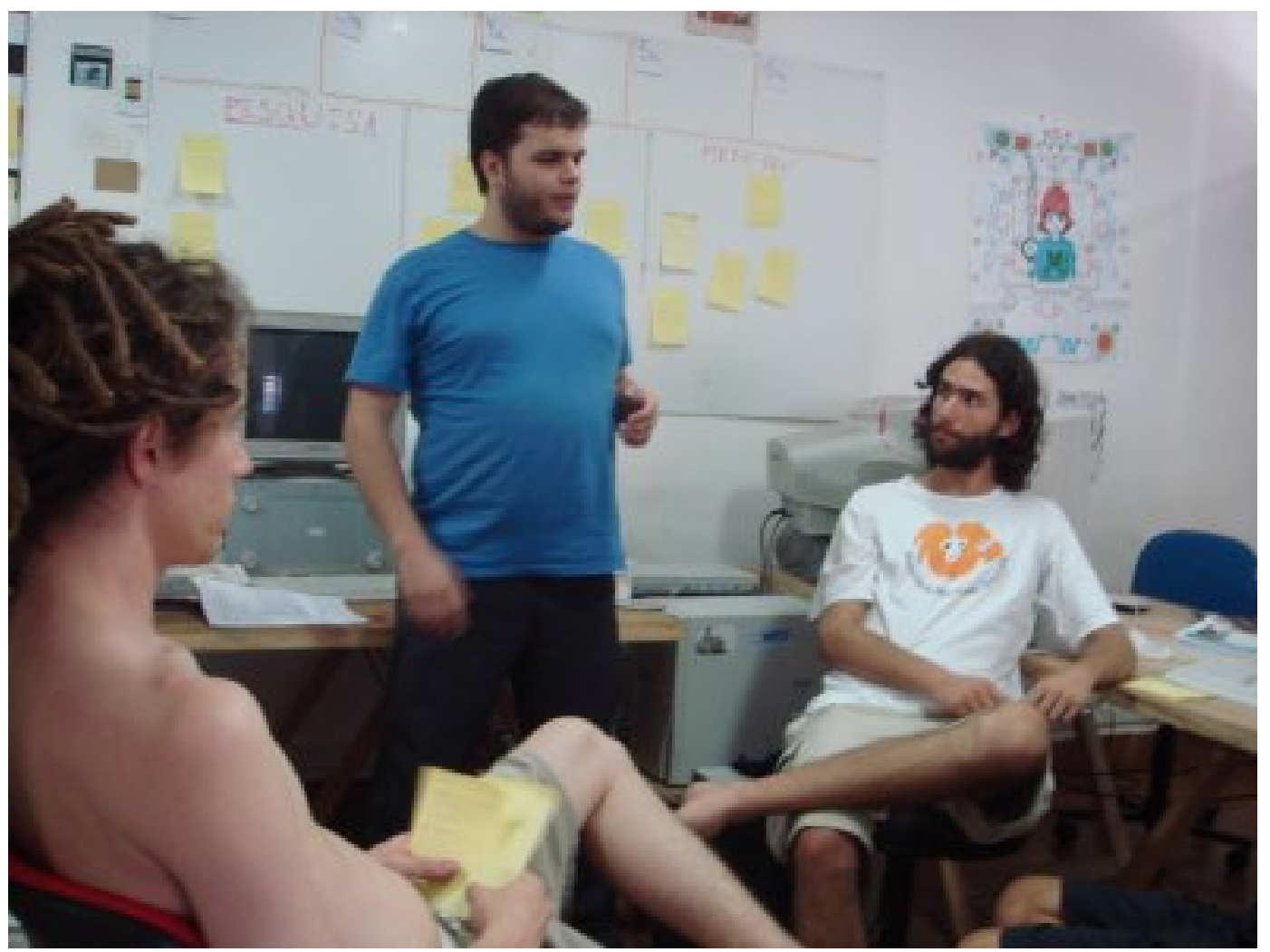

Figura 3.18: Cliente proxy (em pé) durante jogo do planejamento na Cultura Digital

lharam no desenvolvimento de funcionalidades base para o TikiWiki patrocinados pela comunidade. Este evento ficou conhecido como Tiki Brasil Sprint. Mesmo assim, como a renovação com o governo só aconteceu 2 meses depois, após o carnaval de 2006, perdemos dois dos nossos desenvolvedores.

Na retrospectiva do primeiro ano, avaliamos que a adoção de XP andava bem, mas a quebra de continuidade fez com que tivéssemos que começar o ensino da metodologia quase do início. Além disso, por atuar em outras demandas, o autor não pode fazer seu trabalho de treinador de maneira eficiente, estando muito tempo ausente.

No início do segundo ano, perdemos tempo contratando novos desenvolvedores. Além disso uma re-estruturação interna no departamento fez com que o nosso espaço aberto em Brasília fosse transformado em cubículos, provavelmente devido à pressão política dos outros funcionários públicos que não se sentiam confortáveis com nossa produtividade e com a visibilidade do andamento do nosso projeto. Por isso, resolvemos alocar a equipe de desenvolvimento completamente em São Paulo em um novo espaço, desta vez um pouco mais reservado do resto da equipe. Ao longo dos meses, re-estruturamos a equipe com três novos desenvolvedores com pouca experiência de mercado e, desta vez, alguns sem conhecimentos de Orientação a Objetos; e delegamos o papel de cliente proxy a apenas três pessoas, onde cada uma representava somente um sistema. A Figura 3.19 mostra o 
quadro de histórias de algumas iterações.

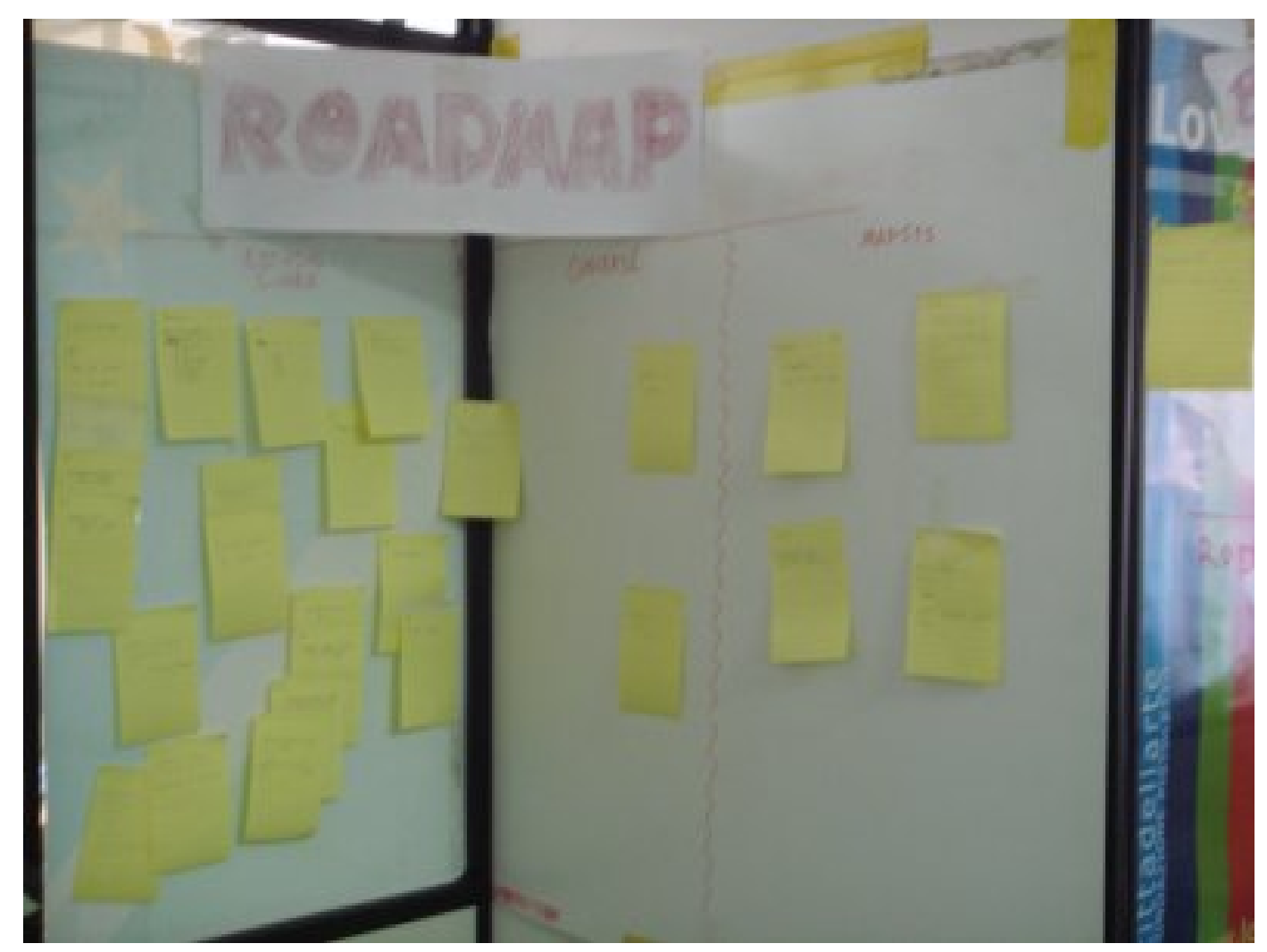

Figura 3.19: Quadro de Histórias de iterações dos 3 sistemas desenvolvidos no espaço aberto da Cultura Digital

Novamente, a adoção de XP não foi tão eficiente pois, como treinador, o autor estava ausente em outras demandas. Mesmo assim, durante este ano conseguimos treinar os novos desenvolvedores em algumas práticas e estabelecemos um ritmo bem satisfatório de releases pequenos. No início do ano, conseguimos entregar uma versão de um dos sistemas a cada duas semanas. No final do ano, já estávamos entregando dois releases de sistemas diferentes por semana. Além disso, no final do ano finalmente conseguimos adotar a prática de testes. A Figura 3.20 mostra dois desenvolvedores pareando em uma tarefa.

Infelizmente, no início do terceiro ano do projeto tivemos novamente problemas políticos na renovação do contrato, devido principalmente à eleição presidencial. Isso causou a perda de dois desenvolvedores.

As maiores dificuldades encontradas foram devidas à ausência freqüente do treinador, a mudança brusca de ritmo e de equipe imposta por fatores políticos e a inexperiência dos desenvolvedores. O uso de clientes proxy foi importante para desenvolver aquilo que os usuários finais necessitavam, porém foi um trabalho árduo para os clientes e causou conflitos na hora de priorizar as demandas dos diferentes sistemas. 


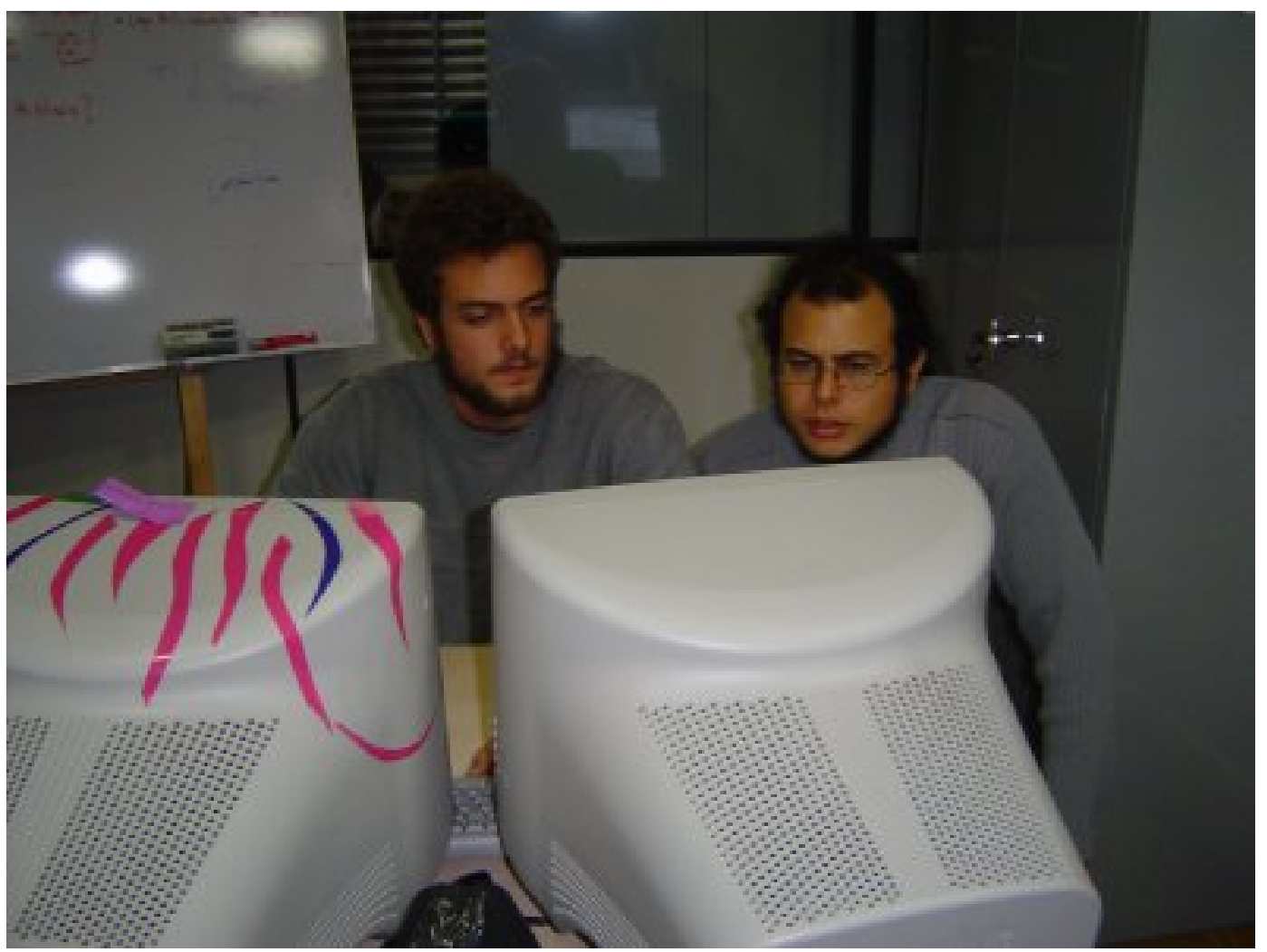

Figura 3.20: Programação pareada no novo espaço da Cultura Digital

Além disso, a pouca participação dos políticos que controlavam o orçamento fez com que estes não percebessem as vantagens do processo ágil e não enxergassem valor nos sistemas sendo criados. Na maioria das vezes, fomos ágeis demais para a máquina pública e tentativas de integração com a equipe do Ministério e sistemas legados, por mais que repetidas, foram sempre frustradas pela inércia do processo burocrático. Em retrospectiva, sugerimos que experiências deste tipo contem com maior participação de políticos no processo de desenvolvimento. Uma possível solução é adotar um cliente proxy dentro do quadro dos funcionários públicos que deve se responsabilizar por fazer a ponte entre a equipe de desenvolvimento e os políticos que controlam o projeto dentro do governo.

Ao mesmo tempo em que observamos dificuldades, o discurso político foi de vanguarda, causando impacto em nível internacional. A oportunidade de implementar um projeto inovador e que quebra paradigmas dentro do governo foi incrível. Por mais que muitos políticos oferecessem resistência ao processo, o Ministro da Cultura em si sempre apoiou nossa prática em seu discurso, explorando e divulgando as possibilidades da Cultura Digital, as formas abertas de comunicação com a comunidade dos pontos de cultura, o software livre e de código aberto, a MetaReciclagem ${ }^{3}$ e a cultura hacker. A Figura 3.21 mostra o Ministro discursando em uma palestra que apresentamos em Londres sobre

\footnotetext{
${ }^{3}$ MetaReciclagem é um processo de re-apropriação tecnológica que utiliza sucata e arte para construção de novos signos técnicos.
} 
Cultura Digital e os Pontos de Cultura.

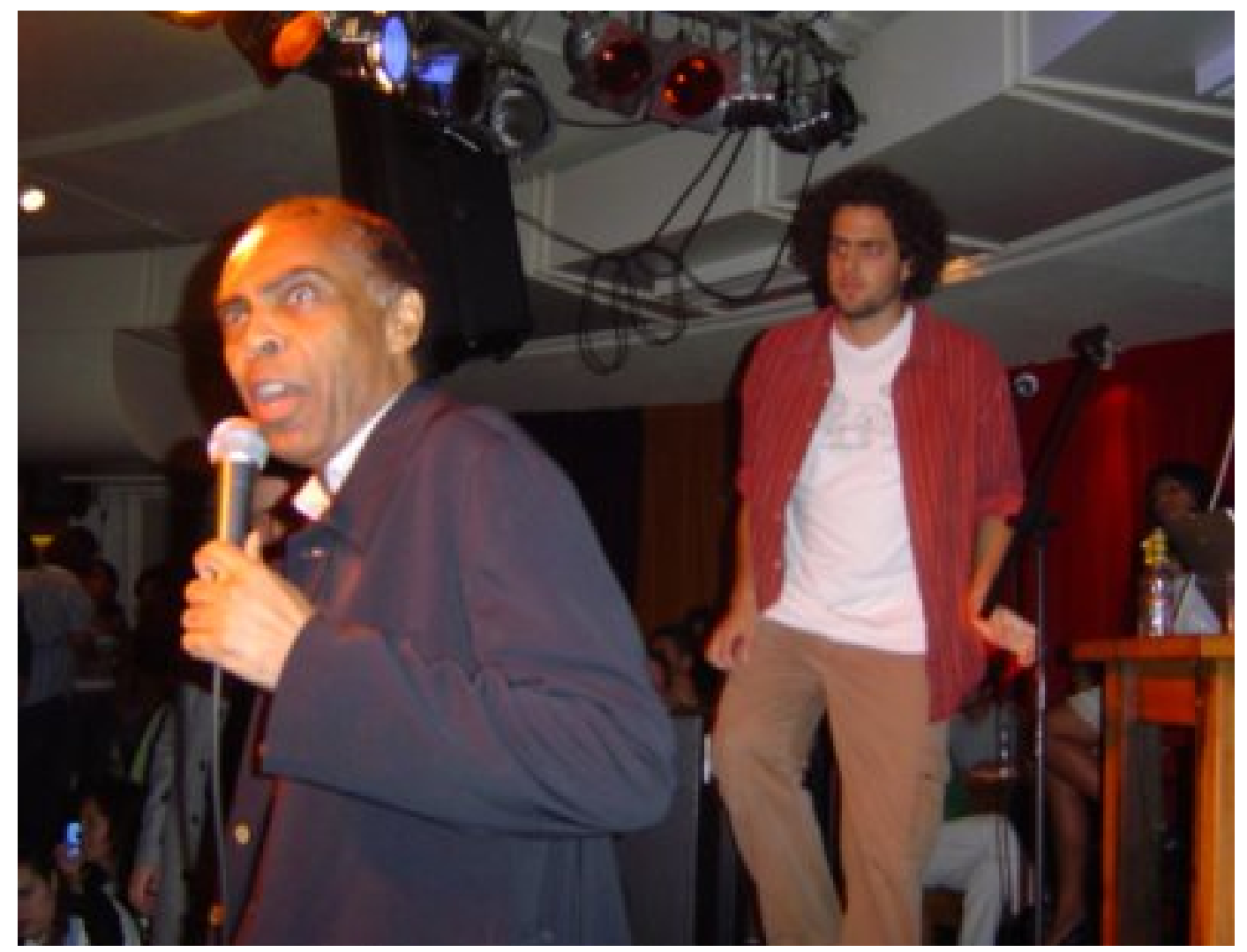

Figura 3.21: O Ministro da Cultura Gilberto Gil fala sobre Cultura Digital em uma palestra em Londres.

Hoje, a equipe continua com as práticas de XP e está re-estabelecendo um ritmo de produção aceitável colocando releases no ar com freqüência. Após o segundo ano de trabalho, ela mostrouse independente do treinador (mesmo muito ausente no processo de ensino da metodologia) e hoje guia o seu próprio processo, explorando possibilidades de colaboração remota e adaptando o jogo do planejamento para lidar com demandas técnicas de evolução dos sistemas e equilibrá-las com vontades das comunidades de usuários que se formaram em torno de cada portal, principalmente devido ao uso de retrospectivas e papos-em-pé que criaram um ambiente de aprendizado contínuo.

É interessante relatar que algumas práticas ágeis usadas pela equipe de desenvolvimento foram adotadas pelo resto da equipe da Cultura Digital com 80 pessoas espalhadas pelo Brasil, principalmente o jogo do planejamento e retrospectivas.

\subsection{Workshops, cursos introdutórios, jogos e eventos com a comunidade}

Além das experiências em cursos mais longos (adaptações de XP à empresas ou equipes de funcionários governamentais), workshops, cursos introdutórios e eventos como jogos ou conferências são úteis e importantes aliados no ensino de XP. Estas modalidades de ensino são menos eficazes do que 
cursos longos, porém são importantes para divulgar o conceito e também providenciar informação para que pessoas possam optar por adotar a metodologia. Nos relatos que vimos, muitas vezes XP aparece como alternativa após algum membro de uma equipe de desenvolvimento entrar em contato com a metodologia através de palestras ou livros.

Participamos de algumas consultorias rápidas nas quais, em um dia, apresentamos, através de palestras, os conceitos da Programação eXtrema. Elas foram importantes para introduzir o tema em empresas e universidades pelo Brasil todo. Foi também a maneira que encontramos para promover o método em conferências e festivais da área. Estas palestras normalmente são seguidas por pedidos de cursos médios ou consultorias.

Além disso, já experimentamos cursos curtos, de um ou dois dias, com grupos pequenos que participam de uma pequena iteração de XP. Nestes, nosso objetivo é aproveitar poucos dias para mostrar a uma organização como funciona a metodologia e como poderia ser feita a transição do modo de trabalhar da organização. Normalmente, apresentamos rapidamente a teoria e depois simulamos uma iteração de um dia, passando por todas as práticas em um projeto simples e rápido.

Ultimamente, temos oferecido dois cursos semanais, um teórico e outro prático. No teórico atendemos também a demanda por informação dos gerentes e administradores de empresa, que podem fazer com que sua equipe técnica participe do prático para aprimorar seus conhecimentos sobre a metodologia. Os cursos foram oferecidos pelo Centro de Ensino de Computação (CEC) do IME-USP tanto para alunos e empresas durante o semestre, quanto como cursos de extensão que acontecem durante os Cursos de Verão do Instituto. O curso teórico conta com exposições sobre diversos temas ligados a metodologias ágeis, aprofundando-se em aspectos mais técnicos como testes e refatoração. O curso prático é uma vivência real: durante uma semana, pequenas equipes participam de um projeto e utilizam todas as práticas de XP com auxílio de um treinador experiente. Nas últimas edições deste curso, equipes desenvolveram um sítio web para comércio eletrônico de pizzas, o AgilPizza. Normalmente, fazemos iterações diárias e de 2 a 3 releases do sistema durante a semana. Utilizamos duas pessoas como clientes proxy, simulando com bastante fidelidade o relacionamento com clientes do mundo real.

Além desses cursos, já realizamos dois tipos de jogos: a eXPerience e o Jogo de XP, ambos rápidos e divertidos. Algumas equipes de poucas pessoas participam de uma atividade lúdica com o intuito de aprender alguma prática ou entender melhor os valores de XP.

Na eXPerience, histórias eram criadas para 4 equipes de 4 pessoas envolvendo a construção de estruturas usando peças magnéticas. Cada história já tinha uma estimativa. Os participantes experimentavam o jogo do planejamento dando prioridade às histórias que seriam executadas em 4 iterações curtas. Eles exercitavam também Programação Pareada já que poderiam resolver duas histórias por iteração por grupo em duas duplas, porém só uma das pessoas da dupla poderia mexer nas peças. 


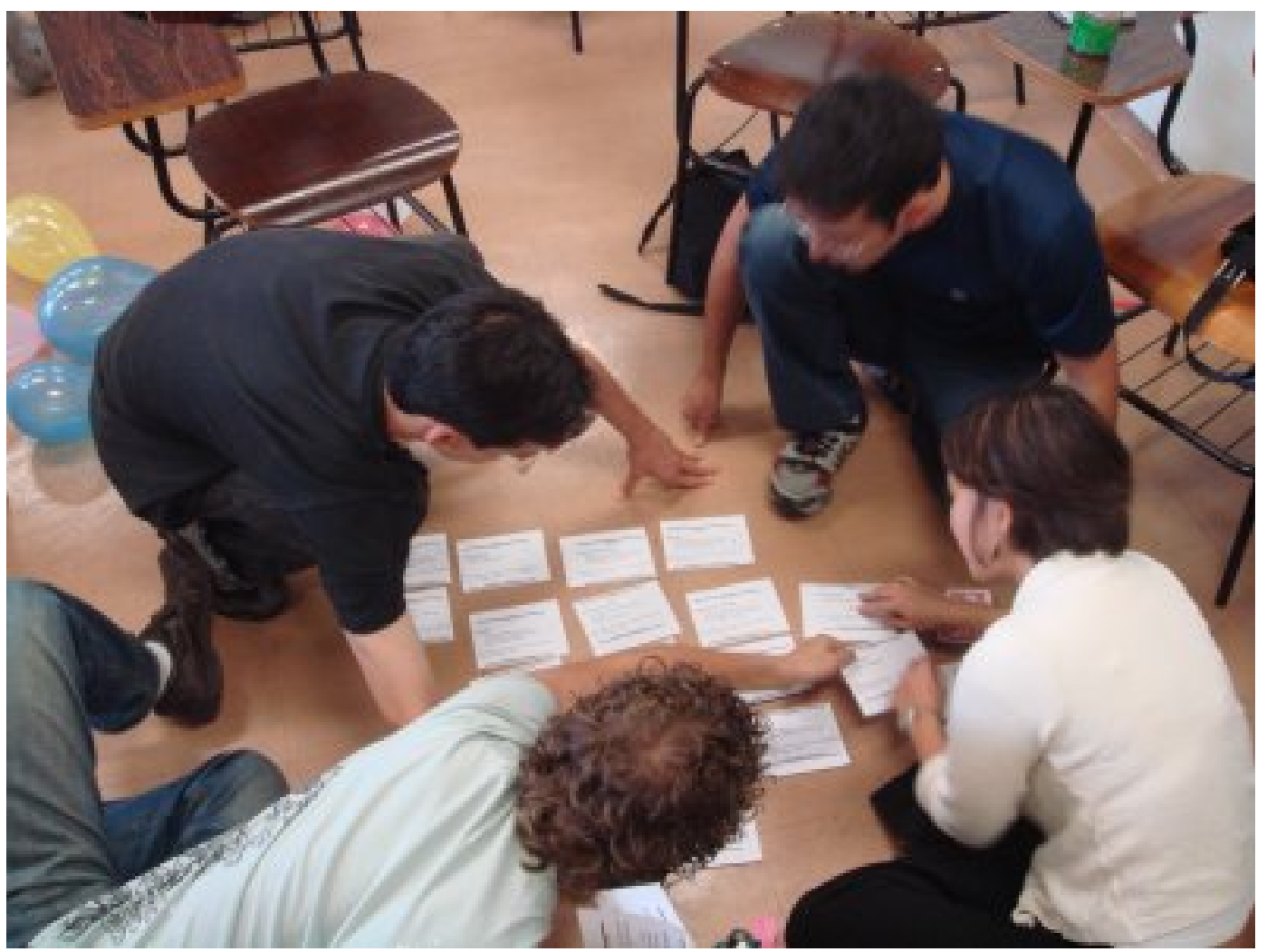

Figura 3.22: Jogadores em um Jogo de XP trabalham para resolver uma história.

No Jogo de XP, a atividade é bem parecida porém todo o grupo trabalha para resolver uma história por vez. O foco é passar conceitos de estimativa e priorização de histórias. Neste jogo, as histórias já tem um valor definido pelo cliente e, em cada rodada, as equipes devem estimar e priorizar as histórias que vão realizar. Normalmente, acontecem 3 rodadas separadas em 3 fases: na primeira os jogadores estimam as histórias e na segunda dão prioridade às histórias que acham que poderão completar na última fase, a de execução. Todas as histórias são simples e geralmente envolvem dobras com papel, operações aritiméticas simples, organização de cartas de um baralho ou até manipulação de bexigas. Ao final do jogo os participantes compreendem também que a velocidade de cada equipe varia de acordo com as estimativas subjetivas que esta aprimora ao longo de iterações. A Figura 3.22 mostra uma equipe trabalhando em uma de suas histórias.

Participar de conferências também é muito importante. Em primeiro lugar para trocar idéias e experiências com outros praticantes e estudiosos. Em segundo, pois é uma excelente oportunidade para conhecer novas técnicas. Nós aprendemos sobre algumas novas práticas ao participar de conferências nacionais e internacionais, conhecemos alguns jogos, retrospectivas e também a técnica de Mapas Mentais, descritos na Seção 4.2.1. O Mapa Mental é um tipo de diagrama voltado para a gestão de informações, de conhecimento e de capital intelectual; a compreensão e solução de problemas; a memorização e aprendizado; a criação de manuais, livros e palestras; a utilização como 
ferramenta de brainstorming; e o auxílio da gestão estratégica de uma empresa ou negócio.

Devemos ressaltar o papel da comunidade no ensino de XP. Sem seu apoio, novidades não chegariam aos implementadores com rapidez e não se compartilhariam as experiências que contribuem para o amadurecimento da metodologia. Em especial, a nossa iniciativa de criar a AgilCoop, uma cooperativa de alunos e professores do IME/USP que se especializam no estudo de Métodos Ágeis, vem sendo elogiada. Uma das atividades que julgamos ser mais importantes na divulgação de métodos ágeis é disponibilizar podcasts sobre assuntos ligados a XP e práticas ágeis, possibilitando que muitas pessoas entrem em contato com essas idéias precisando somente entrar no nosso portal (http://www.agilcoop.org.br) e ouvir nossos programas.

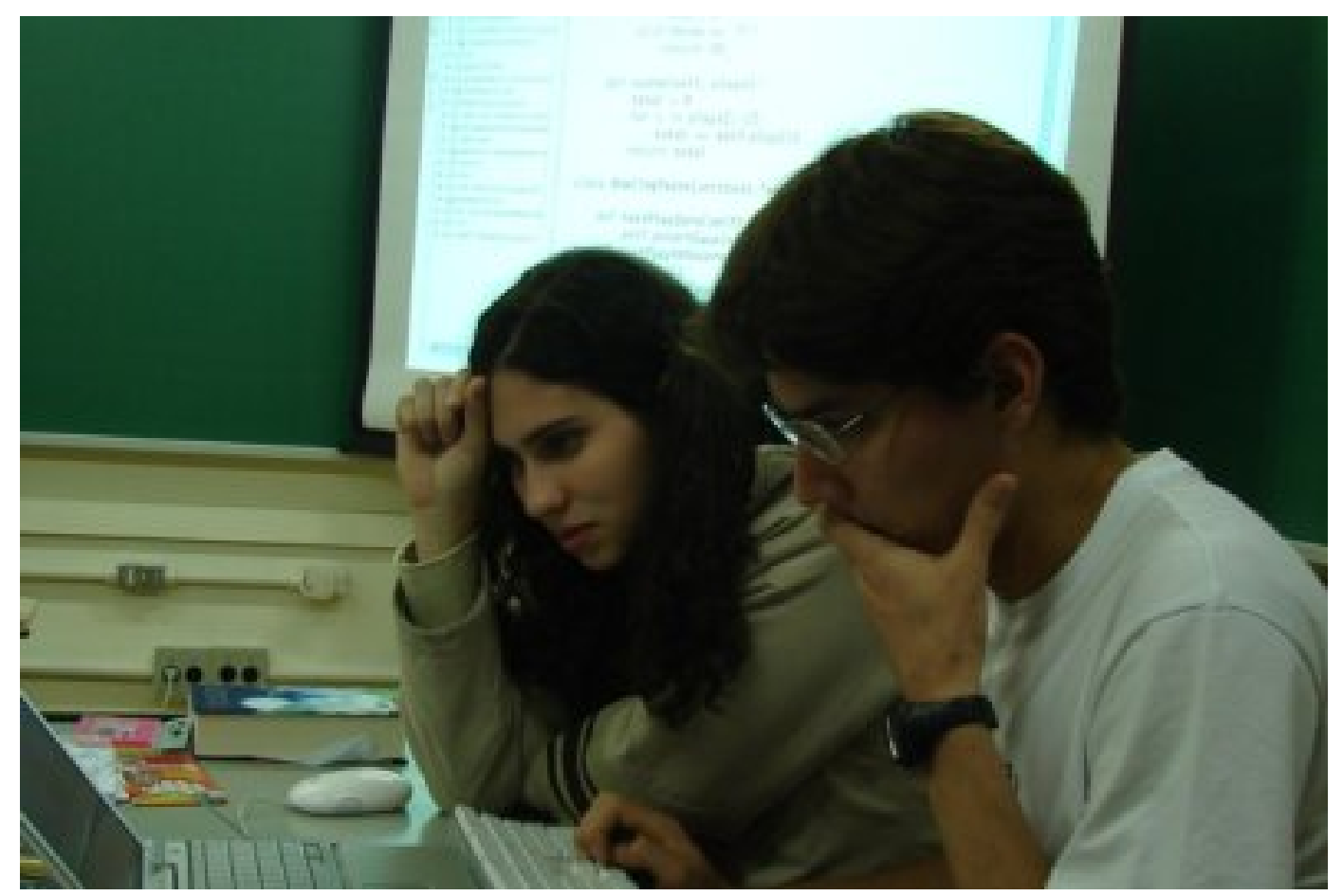

Figura 3.23: Um par se concentra durante um kata do Coding Dojo.

Além dos podcasts, O Coding Dojo (http://codingdojo.org), um evento semanal no IME/USP aberto à comunidade oferece uma oportunidade de aprendizado de diversas práticas ágeis. Neste evento, todos presentes se revezam para parear ao vivo em um projetor (veja a Figura 3.23), ajudandose mutuamente a resolver problemas praticando desenvolvimento dirigido por testes. O Codingo Dojo cria um clima amigável de aprendizado contínuo onde desenvolvedores estudam mais sobre testes, padrões de projeto orientado a objetos e refatoração.

Investir na divulgação da metodologia é investir na sua aceitação no mercado, gerando assim mais oportunidades de atuação com objetivo de melhorar a qualidade da produção de software no Brasil. 


\section{Capítulo 4}

\section{Análise e reflexão sobre o ensino de XP}

Os vários casos estudados mostram que XP pode ser aplicada em contextos variados e que o sucesso não depende somente do modo como se ensina a metodologia. Relatos mostram uma diversidade de experiências de sucesso. Observamos projetos curtos que começaram após um membro de uma equipe estudar XP, conhecendo o método teoricamente. Vimos também projetos longos, com acompanhamento de treinadores experientes, equipe com experiência prévia na metodologia e apoio institucional.

O objetivo final do educador deve ser formar uma equipe proficiente na metodologia de forma que, após algum tempo recebendo apoio de um treinador, torne-se apta a controlar os seus próprios processos. Poderá então refinar suas práticas em um ambiente de aprendizado contínuo no qual a própria metodologia evolui na realidade local. Para alcançar esta meta as diversas abordagens de ensino de XP se complementam, pois a transição de uma organização normalmente ocorre em várias fases. Como Beck sugere em seu livro [BA04], a melhor maneira de implantar XP em uma organização é de forma incremental, em pequenos passos, adaptando a teoria ao contexto local. Linda Rising e Mary Lynn Manns sugerem, em seu livro sobre padrões para introduzir novas idéias [RM05], que pessoas e organizações passam por três etapas até adotarem completamente uma nova idéia: uma etapa inicial de convencimento, uma etapa durante o processo de implantação da idéia e a etapa de amadurecimento após a idéia estar em uso há algum tempo. Existe também uma etapa, paralela às outras, de resistência.

Neste capítulo, iremos analisar as experiências de ensino relatadas e refletir sobre maneiras de tornar a transição para a metodologia mais efetiva em diversos contextos. Apresentaremos linguagens de padrões e anti-padrões que reconhecemos nessas diferentes etapas do ensino de XP. Essas linguagens descrevem práticas e processos, além de alguns erros freqüentes, e podem ser usadas por uma organização que pretende capacitar seus membros para adotar uma metodologia ágil. As linguagens são apresentadas na ordem em que devem ser aplicadas na prática.

Antes, vale ressaltar uma característica comum a todos os casos que estudamos presencialmente: o fato que eles se deram no Brasil. Peculiaridades do contexto e cultura brasileiros podem influenciar o ensino de XP. De acordo com a teoria do homem cordial de Sérgio Buarque de Holanda [dH95] 
brasileiros tendem a reagir com seu coração, desenvolvendo uma necessidade de estabelecer contatos amigáveis e encurtar distâncias. Rejeitamos o uso de sobrenomes e formalidades, referindo-se a todos pelos seus apelidos, até mesmo no espaço de trabalho. Somos incapazes de seguir hierarquias, ou obedecer disciplinas, muito rígidas. Relativo ao ensino de XP existe um impacto positivo: somos abertos a novas experiências, criativos, amigáveis e colaboradores. Porém, o impacto negativo também existe: comparados à maioria das culturas do hemisfério norte, tendemos a não ser pontuais e a extrapolar prazos. Beck comenta que XP é altamente influênciado pela cultura norte-americana e talvez não funcione bem em uma cultura como a nossa, chegando a mencionar no prefácio do livro de Vinicius Teles que o maior empecílio à XP no país talvez seja a falta de comprometimento com prazos, mesmo quando eles podem ser ultrapassados porque toda equipe está se divertindo no trabalho [Tel04].

É importante levar estas questões em consideração na hora de analisar experiências externas e de tentar "tropicalizar" o ensino de XP para que ele se adapte melhor à nossa cultura. Muitos dos padrões que iremos apresentar são reconhecidos na literatura [Bec99, BA04, Amb98, Amb99, CCH96, CH04, RM05, dCFPSB05, FKG07, BT00, KH04]. Apresentamos coletânea abrangente voltada especialmente para padrões que facilitam o ensino no contexto tropical. Iremos traduzir e "refatorar" padrões já documentados, que representam práticas da Programação eXtrema e outras metodologias ágeis, mas vamos também listar novas idéias que reconhecemos nas nossas vivências, nas experiências estudadas e em conversas com membros da comunidade. Esperamos que estas idéias possam auxiliar pessoas assumindo o papel de treinadores de XP no futuro.

\subsection{O cenário ideal}

Observamos algumas características comuns aos casos de sucesso de adoção de XP. Iremos descrever o que consideramos o cenário ideal para ensinar XP nos três contextos estudados. Pessoas que se encontram em situações similares a estas terão sua iniciativa bem sucedida.

$\mathrm{Na}$ academia, a etapa inicial requer que um professor ou um grupo de pesquisa se interesse por métodos ágeis e estude-os a fundo. Experimentar a metodologia na prática, ou associar-se a praticantes com experiência no mercado, é essencial. Estruturar uma disciplina é o próximo passo. Antes disso, é importante oferecer atividades como palestras, jogos e cursos rápidos para divulgar a metodologia para alunos e outros pesquisadores. Uma disciplina optativa nos moldes do Laboratório de XP do IME/USP é uma boa alternativa. Porém, XP também pode ser ensinada com eficácia como uma opção alternativa na disciplina de Engenharia de Software, ou ainda em disciplinas de trabalho de conclusão do curso de Ciência da Computação. A disciplina deve ter duração entre um semestre e um ano, sendo que poucas aulas são utilizadas no início para apresentar a teoria e o maior tempo dos alunos deve ser dedicado a produção de software, em pelo menos duas aulas de 2 ou 3 horas semanais seguindo a metodologia. Em uma das aulas, se possível comida deve ser oferecida aos participantes. No cenário ideal, alunos que já cursaram a disciplina em semestres anteriores se especializam como treinadores de um grupo de até 12 pessoas. 
O treinador também atua como mentor dos alunos, responsabilizando-se por ensinar técnicas mais complexas como testes, refatorações e padrões de projeto avançados. Ele também é um dos desenvolvedores, pareando durante as aulas. Os alunos que participam da disciplina devem ter os conhecimentos técnicos básicos necessários: experiência com orientação a objetos, sistemas de build, integração contínua e padrões de projeto. Um dos alunos se especializa no papel de acompanhador. Este grupo deve ter acesso a um laboratório dedicado, configurado como um espaço aberto e comunicativo, com toda infra-estrutura necessária: quadros brancos, computadores para parear, repositórios de código, wikis, etc..., funcionando e com um administrador dedicado à sua manutenção. Os grupos devem trabalhar continuando o desenvolvimento de projetos de software livre e de código aberto utilizados por organizações parceiras da Universidade. Devem existir algumas opções, que são interessantes tanto pela aplicação em si, quanto pela tecnologia que utilizam. Estes sistemas já devem estar em produção, suas versões anteriores desenvolvidas usando XP, contando com testes automatizados. Clientes reais ou proxy deverão estar disponíveis para trabalhar com as equipes durante as aulas.

$\mathrm{Na}$ indústria, a etapa inicial é diferente se a organização que vai adotar XP já foi formada ou não. O segundo caso é mais fácil. Se a pretensão é criar uma nova empresa que utilize XP, basta garantir que a equipe inicial seja pequena, composta por ao menos um meta-treinador experiente, dois ou três desenvolvedores habilidosos, um ou dois estagiários e um cliente. É importante garantir que esta equipe tenha tempo para aprender as técnicas e que ela conte com um espaço aberto com toda a infra-estrutura necessária. Quando surgir a necessidade de ampliar, é possível que os desenvolvedores mais experientes e habilidosos assumam o papel de treinadores. Novas contratações devem acontecer levando em conta o ambiente ágil e as pessoas contratadas devem adaptar-se rapidamente ao modo de trabalho da equipe. Pessoas que resistem excessivamente devem ser retiradas naturalmente. Para obter uma base de código inicial e um ambiente de desenvolvimento rapidamente, o projeto deve ser produzido utilizando ferramentas e arcabouços livres e de código aberto de qualidade.

Já no caso de uma organização existente, é importante começar convencendo o nível administrativo organizando palestras, jogos, reuniões com treinadores experientes e até mesmo fazendo com que membros da equipe participem de cursos rápidos. É essencial escolher um grupo pequeno com alguns desenvolvedores experientes e contratar um meta-treinador para auxiliar este grupo no aprendizado de XP durante um projeto piloto no qual um cliente deverá estar disponível. O sucesso deste projeto piloto irá certamente impactar as demais áreas e grupos dentro da empresa.

No governo, pode-se começar organizando palestras para divulgar a metodologia. Quando a idéia contar com a força política necessária, deve-se organizar um curso rápido para alguns funcionários. É necessário contratar um treinador experiente para atuar como meta-treinador desta equipe em um projeto de médio prazo para o qual um cliente proxy bom tem que estar disponível. É preciso organizar um espaço próprio para a equipe e adotar ferramentas e arcabouços livres e de código aberto. 
Sabemos que situações ideais raramente ocorrem. Nas próximas seções, analisaremos os casos que estudamos e refletiremos sobre padrões e anti-padrões que podem ser adotados nas diferentes etapas do ensino de XP, assim podendo nos aproximar destas situações ideais.

\subsection{Etapa inicial - Começando o processo de transição}

Observamos que o processo de transição metodológica para XP normalmente começa a partir da iniciativa de um ou poucos indivíduos dentro de uma organização, Rising e Manns chamam estas pessoas de "evangelistas" [RM05]. Em geral, uma pessoa assume a responsabilidade de guiar a adoção da idéia até esta ser colocada em prática. Durante este processo, é preciso preencher os papéis do treinador, do cliente e estruturar uma equipe de desenvolvimento. Deve-se também definir qual o sistema que será desenvolvido e articular um plano de longo prazo com os temas do projeto. Montar um espaço de trabalho com a devida infra-estrutura é um dos últimos passos. A etapa inicial termina logo após a fase de exploração do primeiro ciclo de estação, quando a equipe entra em um ciclo de iterações de desenvolvimento já usando XP como metodologia. Em nosso estudo, observamos diferentes maneiras de começar este processo. Os atores envolvidos e seus objetivos variam nos diferentes contextos.

$\mathrm{Na}$ academia, o processo é iniciado quando um professor ou um grupo de pesquisa decide ensinar métodos ágeis aos alunos. Se o objetivo é colocar os alunos em contato com o método, eles optam por oferecer cursos curtos ou incluir XP como tópico de disciplinas existentes. Já se pretendem capacitar os alunos a trabalharem com a metodologia, propõe alterações a disciplinas existentes como Engenharia de Software ou Trabalho de Conclusão de Curso, ou a criação de uma nova disciplina optativa como o Laboratório de XP.

Na indústria, existem casos de organizações que adotam XP desde sua criação e também transições metodológicas em organizações existentes de diversos tamanhos. Se uma organização está sendo criada, normalmente a idéia surge do nível administrativo ou do responsável pela equipe de TI, com objetivo de criar um ambiente de aprendizado contínuo que permite que a organização cresça. Se a organização já existe, normalmente a idéia é apresentada por um gerente de desenvolvimento ou membro de uma equipe técnica com objetivo de experimentar a metodologia em um projeto específico, ou piloto, para que ela seja validada e aplicada em outras partes da organização.

No governo existem casos de equipes inteiras que trabalham presencialmente em alguma instituição para desenvolver projetos específicos. A idéia de adotar XP normalmente parte de membros desta equipe. Em alguns casos, gerentes de departamentos de Tecnologia da Informação resolvem mudar a metodologia de trabalho adotada com o objetivo de criar um ambiente de desenvolvimento mais ágil e melhorar o relacionamento com a base de usuários finais dos sistemas produzidos.

Tanto na indústria quanto no governo, poucos são os casos em que a iniciativa provém diretamente do nível administrativo de uma organização. 


\subsubsection{Padrões para convencer sua organização a praticar XP}

Em qualquer contexto, o primeiro e mais importante passo nesta empreitada é obter conhecimento teórico sobre os Métodos Ágeis. Além disso, todos envolvidos devem entender os valores, princípios e práticas de XP. É necessário estar preparado para lidar com a resistência de muitas pessoas. Recomendamos, antes de tudo, artigos e materiais de referência disponíveis na Internet e nos livros básicos que referenciamos nesta dissertação. Este padrão se chama Lição de Casa.

Durante esta etapa inicial, quanto mais pessoas conhecerem e se interessarem por essas alternativas previamente, maior a chance de sucesso de uma experiência prática. Para isso, distribuir materiais sobre XP para que interessados possam se aprofundar teoricamente também é essencial. Este padrão se chama Plante as Sementes.

Muitas referências estão disponíveis principalmente em portais ligados à comunidade ágil, onde podemos encontrar artigos, histórias de sucesso, listas de discussão, fóruns e até mesmo podcasts e vídeos sobre o tema. É importante ajudar as pessoas a conhecerem estes ambientes de interação com a comunidade. Este padrão se chama e-Forum.

Organizar um grupo de estudos na instituição é uma boa maneira de divulgar estes materiais, os métodos ágeis e alguns temas relacionados (por exemplo, desenvolvimento orientado a objetos, testes automatizados, refatoração, padrões de projeto e o uso de arcabouços livres e de código aberto). Esse padrão se chama Grupo de Estudos.

Um bom padrão para que as pessoas consigam explorar sua compreensão dos valores, princípios e práticas de XP é usar Mapas Mentais. A Figura 4.1 mostra um exemplo de mapa mental, criado em um grupo de estudos do qual participamos durante um workshop ministrado por Beck na conferência XP 2007, explorando a compreensão das práticas da metodologia ligadas ao planejamento de um projeto .

Assistir palestras e participar de conferências é importante para entrar em contato com pessoas que já tem experiências práticas e de sucesso. É também uma oportunidade onde dúvidas referentes à teoria estudada podem ser esclarecidas. Além disso, estar em contato com a comunidade é importante para que se possa encontrar pessoas aptas a ajudar nesta etapa inicial. Estes padrões se chamam Participe de Eventos e Conheça a Comunidade. Em nossa experiência, palestras em eventos foram importantes para organizar cursos rápidos ou médios em organizações interessadas por XP.

Divertir-se em jogos como o Jogo de XP e a eXPerience é uma maneira eficaz de entender conceitos filosóficos das metodologias ágeis, além deles fornecerem uma idéia geral sobre como funcionam algumas práticas e por que elas poderiam ser úteis num determinado contexto. Este padrão se chama Deixe eles brincarem.

Cursos rápidos ou de média duração são uma excelente oportunidade de apresentar a metodologia para mais pessoas. Em nossa experiência, cursos de um ou dois dias são suficientes para introduzir 


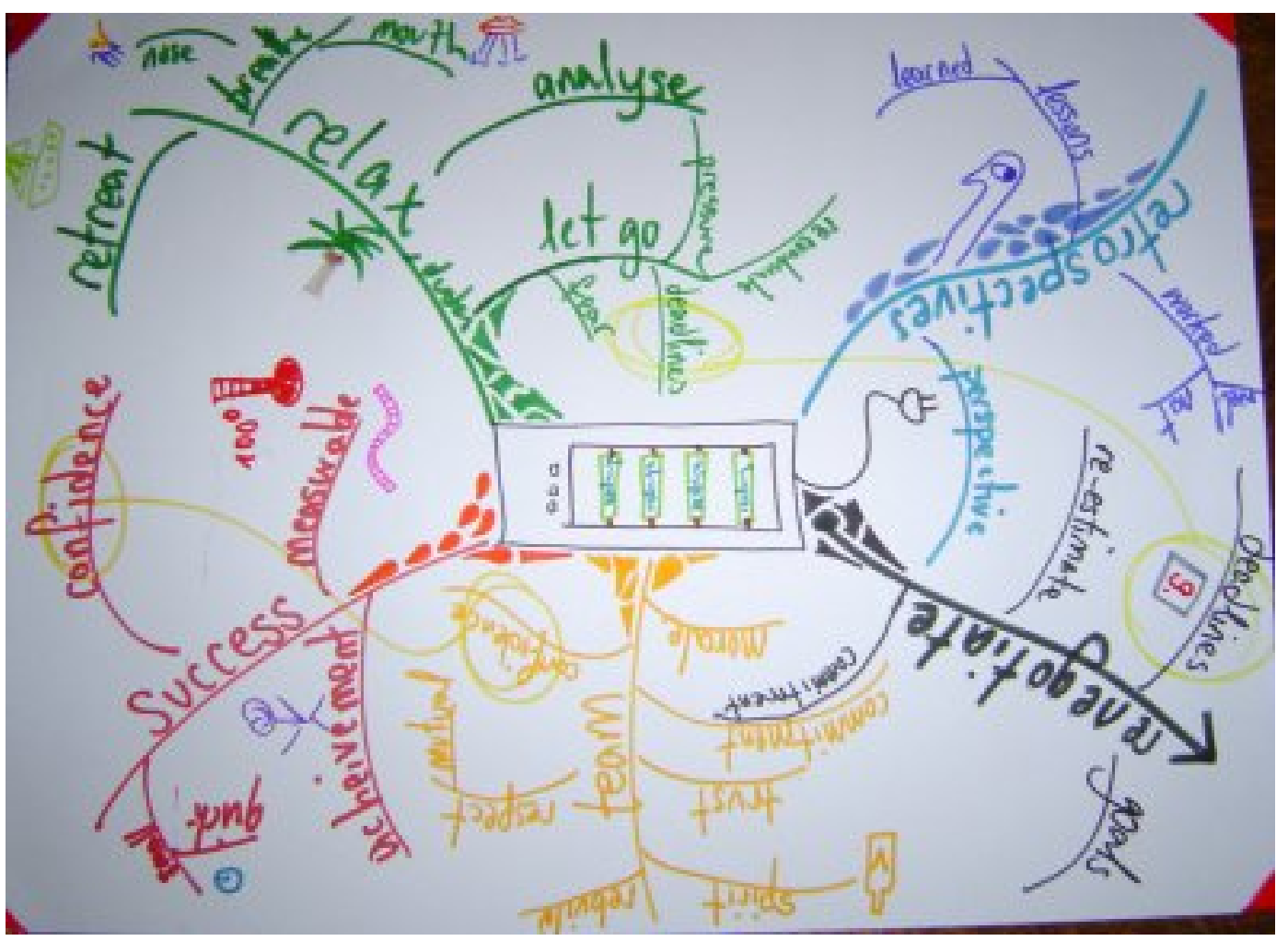

Figura 4.1: O padrão Mapa Mental pode ser usado para entender melhor a metodologia. Neste mapa mental criado em grupo de estudos da conferência XP 2007 visualizamos as práticas relacionadas ao planejamento de um projeto

brevemente a teoria da Programação eXtrema e dar uma idéia mais clara aos participantes de como funciona a metodologia na prática. Eles devem contar com uma exposição teórica, exemplos práticos das técnicas mais complexas, como refatoração e testes automatizados, além de um simulação rápida das etapas envolvidas em uma iteração XP. Cursos médios, de uma ou duas semanas, nos moldes dos que oferecemos em colaboração com a AgilCoop são alternativas tanto para tomadores de decisão, quanto para equipes técnicas. Um curso é teórico e apresenta mais detalhes das metodologias ágeis e suas práticas mais complexas. Outro é prático e oferece uma primeira vivência em um projeto que funciona seguindo os valores, princípios e práticas das metodologias ágeis. A carga horária é de 40 horas.Estes padrões se chamam Curso Rápido e Curso Médio.

Até mesmo na academia, palestras, jogos e cursos são importantes para aguçar o interesse de alunos e despertar o interesse de outros pesquisadores. Na nossa experiência, palestras onde alunos do Laboratório de XP apresentaram seus projetos foram importantes aliadas de jogos e cursos para melhorar a receptividade de novos oferecimentos da disciplina. 


\subsubsection{Padrões para lidar com a resistência inicial}

Por mais que nossa cultura seja aberta a novas idéias, sempre observamos a etapa da resistência em nossos estudos. Na academia, esta é peculiar, pois ao optar por um curso de XP, os alunos já estão convencidos a aprender a nova metodologia, então apresentam pouca resistência à idéia. Vale ressaltar que neste contexto, a resistência provêm de alunos que já têm experiência profissional como estagiários, em forma de dúvidas sobre aspectos extremos e como implementá-los em um caso real, onde sabem que irão encontrar mais dificuldades. Observamos ainda que estes são os alunos que realmente conseguem apreciar a mudança proposta pela metodologia, pois sofreram com métodos tradicionais em projetos passados.

Em outros contextos, encontramos muito mais resistência à mudança, principalmente vinda de administradores e gerentes em empresas, ou burocratas no governo, céticos quanto às práticas "extremas" da metodologia. Mas também há resistência de desenvolvedores que já tem muita experiência de trabalho. Tomadores de decisão questionam práticas que aparentemente utilizam recursos de maneira ineficiente, como programação pareada ou o contrato de escopo negociável. Desenvolvedores criticam a metodologia por temer o desconhecido ou sentirem-se ameaçados, como no caso do processo de inspeção contínua instaurado pela prática de propriedade coletiva do código ou pela prática de acompanhamento.

O papel do treinador começa justamente durante esta etapa inicial, pois sua experiência é importante para lidar com esta resistência. Ele deve debater críticas comuns aos métodos ágeis e tranqüilizar pessoas com medo de passar pela mudança cultural necessária. O padrão Mentor dita que a pessoa que pretende introduzir métodos ágeis em sua organização deve contar com o apoio de treinadores ou membros conhecidos da comunidade. Recomendamos fortemente que, caso a pessoa que pretende introduzir métodos ágeis na organização não tenha participado de ao menos duas experiências práticas com estes, um mentor externo seja convidado para participar da transição. Ele pode inclusive ministrar palestras, jogos e cursos para a organização: quando um agente externo também apóia a idéia, a chance de outras pessoas darem valor a ela aumenta. Estes padrões são chamados de Grande Personalidade e Validação Externa.

Além disso, mentores podem participar de reuniões e almoços com tomadores de decisão para explicar-lhes os benefícios desta nova metodologia ou contar sobre suas experiências de sucesso. Foi num almoço que conseguimos convencer o CEO de uma empresa que programação pareada era uma boa prática para sua organização usando o argumento do fator caminhão ${ }^{1}$. Estes são os padrões

\section{Almoço VIP e Histórias de Sucesso.}

Quando iniciativas partem de uma equipe em uma organização existente, a resistência normalmente surge de pessoas que ocupam um nível intermediário: gerentes em empresas e burocratas no governo. Neste caso, cabe ao treinador convencer alguém no nível mais alto da organização de

\footnotetext{
${ }^{1} \mathrm{O}$ fator caminhão indica quantas pessoas podem ser atropeladas por um caminhão até que uma organização pare de produzir. A programação pareada aumenta o fator caminhão.
} 
que XP é uma boa idéia. Esta pessoa deve ajudá-lo então a garantir que a transição tenha apoio institucional. Este padrão é chamado de Patrocinador Local.

Outro papel importante que começa durante a etapa inicial é o papel do cliente. É normalmente em uma negociação com ele que decide-se adotar a metodologia. Para lidar com a resistência inicial de clientes, uma alternativa é simular um jogo do planejamento com a presença de somente o treinador e o cliente, onde temas de um ciclo de estação são discutidos e histórias são criadas levando em consideração o longo prazo de um projeto. Em nossa experiência, uma reunião inicial somente com o cliente na Paggo, na qual realizamos um planejamento assim, foi suficiente para finalmente convencêlos a contratar um treinador e adotar XP. Na experiência analisada por Vinicius [Tel05], este padrão também foi utilizado para convencer clientes a adotar a metodologia. Pode-se escolher um dos temas discutidos neste encontro para estruturar um primeiro projeto onde uma equipe vai aprender XP. Chamamos este padrão de Primeiro Planejamento VIP.

\subsubsection{Padrões para escolher um treinador e envolver-se realmente com o cliente}

Vimos que preencher os papéis do treinador e do cliente é importantíssimo para garantir o sucesso em qualquer contexto. Por mais que acreditemos que participantes de um curso médio possam começar uma transição, adotando algumas práticas em um ritmo de pequenos passos, recomendamos fortemente que a organização inclua no seu processo de adoção uma etapa de aprendizado mais longa, com o apoio de um treinador experiente. As modalidades de ensino mais curtas não são suficientes para capacitar alguém a praticar a metodologia de maneira autônoma e independente pela primeira vez. Por mais que observamos casos onde uma ou poucas pessoas sem experiência prática prévia implantaram XP, esses casos são os que passaram por mais problemas. Chamamos este anti-padrão de Faça Você Mesmo.

Observamos que na indústria e no governo o formato mais recomendado é o de que a equipe contrate um meta-treinador como consultor para dar o apoio necessário durante o processo de ensino da metodologia. Chamamos este padrão de Meta-Treinador e ele funcionou muito bem na Paggo. Em nossa experiência no governo, a pessoa que deveria assumir o papel de treinador tinha inúmeras outras responsabilidades, de maneira que o processo de ensino foi mais tortuoso e longo do que esperado.

$\mathrm{Na}$ academia, recomendamos que um curso mais longo, com ênfase na prática, também seja oferecido. Observamos através de nossas experiências que alunos que participam deste tipo de curso estão aptos a praticar XP em uma organização. Sugerimos que, se o aluno pretende ser o treinador de uma equipe transitando para XP, este participe de ao menos duas experiências práticas com a metodologia. Notamos que o melhor formato para um curso acadêmico de XP permite que alunos participem dele duas vezes, na segunda se especializando no papel de treinador. Chamamos este padrão de Faça Duas Vezes e observamos que alunos que tiveram esta experiência estavam aptos a treinar uma equipe. 
Contar com um cliente real e garantir sua presença desde o início do aprendizado de XP pode ser decisivo para o sucesso de uma experiência. Na Paggo, tivemos sorte de contar com um cliente interno à organização, entusiasta das práticas ágeis de XP. Mas esta não é a norma. No governo observase uma situação peculiar, pois a maioria dos sistemas desenvolvidos atendem a uma grande base de usuários (são serviços públicos afinal) e é difícil definir um cliente. Muitas vezes até os próprios desenvolvedores são potenciais clientes. Na academia, muitos cursos optam por não definir um cliente real, porém os casos de maior sucesso contavam com clientes externos às equipes de desenvolvimento e até mesmo à própria instituição. É recomendado elaborar projetos com parceiros da Universidade para garantir clientes interessantes. Para atrair potenciais parcerias, pode-se oferecer um sistema livre e de código aberto desenvolvido sob medida. Em contrapartida, o parceiro disponibiliza um representante para participar de jogos do planejamento, apresentações de releases, para apoiar a equipe e escrever testes de aceitação.

Chamamos este padrão de Use Clientes Reais. Em todos estes contextos vale aplicar o padrão Cliente Proxy que explicitamos na Seção 2.6. No caso do curso médio prático da AgilCoop, observamos que utilizar duas pessoas como clientes proxy criou um ambiente muito mais próximo do real na simulação de desenvolvimento do portal AgilPizza. Isso se deu pois ao interagir com pessoas diferentes, mudanças de idéia são garantidas com maior freqüência.

Na indústria, também se aplicam os padrões Contrato de Escopo Negociável e Pague pelo Uso reconhecidos por Beck [BA04]. Ambos ajudam uma empresa a estabelecer melhor o papel de cliente. Ao assinar um contrato de escopo negociável um cliente potencial está se comprometendo a colaborar como a metodologia prevê. Ao cobrar pelo uso de um sistema a empresa faz com que todos usuários componham o papel do cliente. Algo similar pode acontecer no governo. No projeto da Cultura Digital, a comunidade de usuários dos sistemas contava com canais para interagir com os desenvolvedores diretamente, podendo participar de discussões em listas e eleger um cliente proxy para participar de jogos do planejamento. Chamamos este padrão de Comunidade de Usuários Ativa.

Em especial, no contexto acadêmico, observamos um anti-padrão interessante denominado Personalidades Múltiplas. Ele descreve o erro comum de uma mesma pessoa assumir ambos os papéis de treinador e cliente, podendo levar a resultados esquizofrênicos [FKG07]. Assumir ambos papéis, reconhecidamente trabalhosos e complexos, é uma tarefa estressante e pode confundir tanto a pessoa quanto os desenvolvedores da equipe. Estes não sabem dizer se a pessoa está guiando o time e fazendo com que todos sigam as regras do jogo, como treinador, ou se ela esta tentando escrever, validar histórias, ou prover feedback claro sobre requisitos, como cliente. Este problema não é difícil de resolver se existe coragem e disciplina, ou se a equipe é pequena. Quando é absolutamente impossível designar outra pessoa para assumir o papel de cliente proxy ou treinador, usar um chapéu e brinquedos para claramente distinguir o Treinador do Cliente pode ser uma maneira bem humorada de carregar este fardo. Utilizamos esta solução no projeto Cigarra. Observamos que o uso do chapéu ajudou a pessoa a concentrar-se para atuar da maneira correta. Conseguimos até simular conversas 
entre o cliente e o treinador. A Figura 4.2 mostra o uso de um chapéu por um treinador/cliente de personalidades múltiplas.

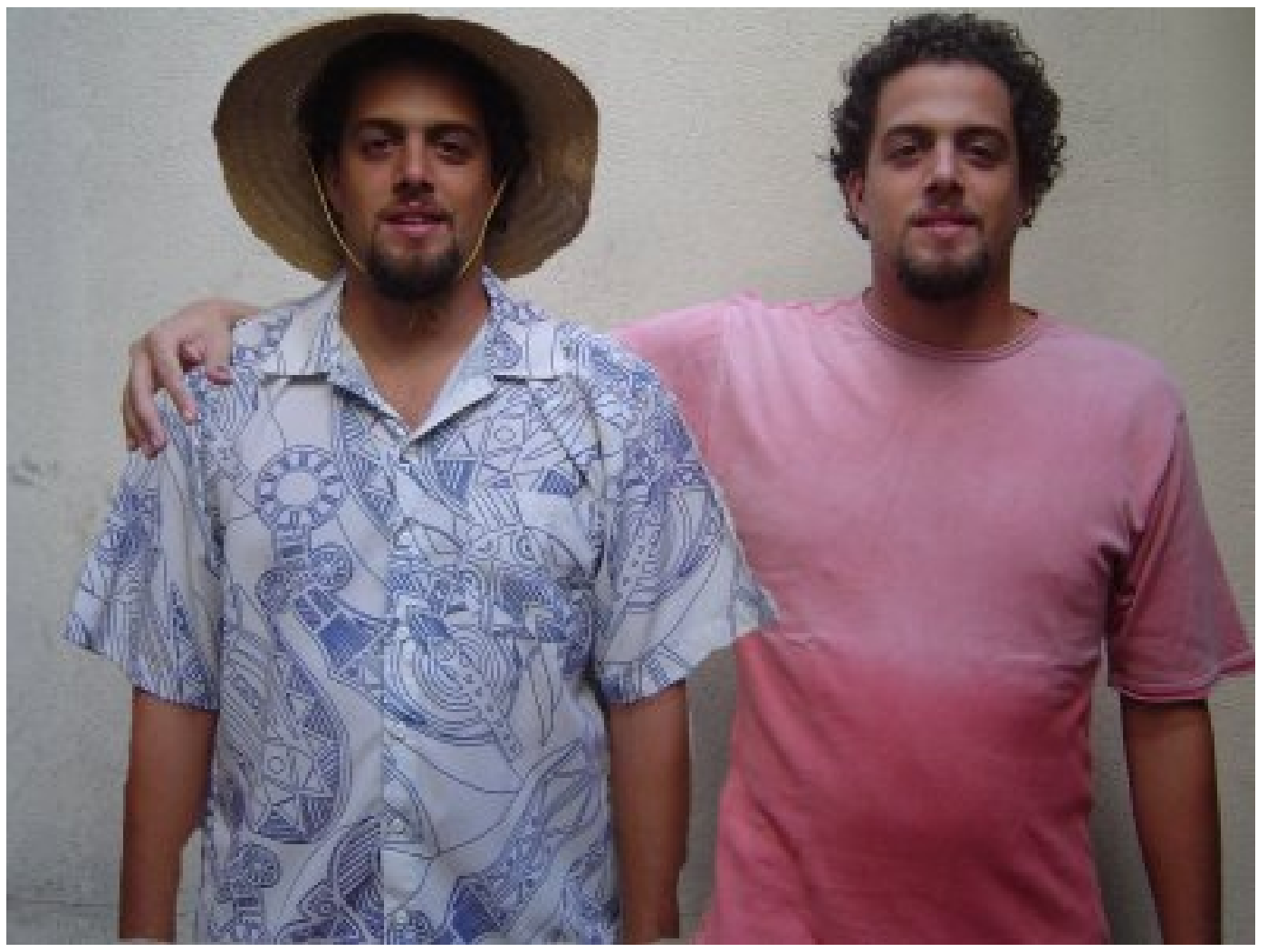

Figura 4.2: O anti-padrão Personalidades Múltiplas pode ser resolvido com um chapéu

\subsubsection{Padrões para montar uma equipe}

Com mais conhecimento em mente, os interessados podem partir para estruturar experiências mais práticas dentro da organização. Para isso é preciso preencher alguns papéis além do treinador e do cliente. O tamanho e a composição da equipe que vai adotar XP também são importantes. Este padrão é chamado por Beck de Time Completo [BA04] e também é reconhecido por Coplien [CH04]. Observa-se que contratar especialistas nos domínios da aplicação garante que os conhecimentos necessários estarão à disposição da instituição. Nota-se ainda que uma pessoa pode preencher mais de um papel necessário à equipe. Recomendamos que equipes não ultrapassem 12 pessoas. Nossa única experiência prática com uma equipe de 12 pessoas ocorreu durante o desenvolvimento do Cigarra, ensinar um time grande é uma tarefa complexa. Se a equipe de desenvolvimento é maior do que isso, é preciso separar um grupo menor para a primeira experiência de aprendizado de XP. Veremos que é possível aumentar o tamanho da equipe mais adiante no processo de aprendizado. Além disso, é importante contar com pelo menos algumas pessoas jovens. O anti-padrão de compor uma equipe sem jovens é reconhecido por Alexander [AIS+77] como Velhos Para Todos os Lados. 
Em todos os contextos, é importante preencher o papel do acompanhador. Este papel envolve habilidades de observação e criatividade na criação de radiadores de informação. Na indústria e no governo, observamos que estagiários funcionam bem no papel, é o padrão Estagiário Acompanhador. Na academia, recomendamos que um ou mais alunos assumam este papel, adotando o padrão de Papéis Secundários também observado por Dubinsky [DH04]. Este padrão também pode ser usado para que outros alunos assumam responsabilidades de outros papéis (como treinador, responsável por testes, etc.). O padrão também pode ser aplicado nos outros contextos, onde é interessante ter um número ímpar de pessoas (3 a 7) assumindo papéis secundários além do papel primário de desenvolvedor, como nota Coplien [CH04]. No Laboratório de XP, também recomendamos que os acompanhadores mantenham informações de acompanhamento on-line para que os alunos possam trabalhar em suas histórias e atualizar o andamento do projeto fora do laboratório. Chamamos este padrão de Acompanhamento On-Line.

É claro que a composição da equipe de desenvolvimento é essencial para o sucesso de um projeto. Nota-se que é impossível praticar XP somente com iniciantes. Uma questão que observamos em todos os contextos e que pode afetar o andamento de uma transição metodológica é a necessidade de que programadores da equipe atendam a alguns pré-requisitos. Por exemplo, é praticamente impossível ensinar refatoração a alguém que não saiba antes programar orientado a objetos. Tentar adotar XP sem antes cumprir estes pré-requisitos é o anti-padrão que chamamos de Carro na Frente dos Bois. Como solução na academia é importante indicar aos alunos quais os conhecimentos necessários como pré-requisito para a disciplina. Já na indústria e no governo, é importante contar com pelo menos algumas pessoas habilidosas e experientes na equipe. Este é o padrão Contrate Especialistas. Também é possível treinar pessoas menos experientes ao mesmo tempo em que se ensina a metodologia. Este é o padrão Estagiário Aprendiz.

Em muitos casos, a resistência apresentada por desenvolvedores ao aprendizado de XP é justamente devida ao fato de desconhecerem as técnicas mais complexas exigidas. Nesses casos, investir em Cursos Médios é importante. Além disso, cursos específicos sobre tópicos como Programação Orientada a Objetos podem ser necessários. Este é o padrão Domine os Pré-Requisitos. Na indústria e no governo também notamos muita resistência de desenvolvedores sêniores com muita experiência. Por estarem acostumados à sua própria maneira de trabalhar, a mudança cultural necessária pode ser muito difícil. É importante evitar muitos destes na equipe. Chamamos este anti-padrão, bem-humoradamente, de Velhos Dinossauros. Na academia, notamos que resistência surge por parte de alunos que já tiveram experiência no mercado. Porém, recomendamos fortemente que estes alunos participem de disciplinas como o Laboratório de XP, já que vimos que por terem sofrido com outros métodos na prática eles darão mais valor às mudanças propostas pela metodologia. Além disso, podem apoiar o treinador a engajar a equipe de desenvolvimento. Chamamos este padrão de Experiência Prévia. 


\subsubsection{Padrões para estruturar o espaço de trabalho}

O espaço de trabalho também influi muito em uma experiência de aprendizado de XP. A prática de Espaço de Trabalho Informativo é um padrão fácil de ser aplicado. Recomendamos que o espaço seja amplo, contenha computadores de forma que duas pessoas possam praticar programação pareada, mas que também conte com um espaço reservado para que membros da equipe possam lidar com questões privadas. Se possível deve-se estruturar a primeira experiência de aprendizado de forma que toda a equipe possa seguir o padrão Sentar Juntos. Mais adiante veremos como lidar com casos onde a equipe está distribuída geograficamente.

O uso de uma parede e um quadro branco para aplicar o padrão Radiadores de Informação também é recomendado. Vimos que o importante destes radiadores é comunicar facilmente a métrica observada, não precisando ser objetos estéticos. Além do espaço de trabalho físico, em nossa experiência na academia incentivamos acompanhadores a estruturar um espaço virtual, disponível online, onde medições e informações são armazenadas. Recomendamos o uso do software livre XPlanner para armazenar histórias e tarefas bem como o andamento do projeto e o uso de um Wiki para que a equipe possa documentar suas idéias e combinados. Chamamos este padrão de Espaço Virtual Informativo. No contexto governamental, um espaço como estes é recomendado para que a equipe de desenvolvimento possa prestar contas de maneira visível a toda comunidade de usuários dos sistemas. Equipes distribuídas também podem se beneficiar da adoção deste padrão.

Além do espaço é importante prestar atenção a questões de infra-estrutura básica para que o processo de aprendizagem aconteça sem empecilhos. Configurar um servidor para a equipe contar com um repositório de código fonte desde o início do projeto é importante. Além disso, recomendamos que a infra-estrutura conte com contas de usuários configuradas com todo um ambiente de desenvolvimento. Nelas devem estar instalados os arcabouços, servidores de aplicação, bancos de dados, ferramentas e a documentação da tecnologia que será utilizada no projeto.

Recomendamos fortemente que a equipe preencha um papel de administrador que zele pelo funcionamento desta infra-estrutura. É o padrão Got Root? Em nossa experiência na academia, foi importante contar com alguns alunos bolsistas encarregados de manter a infra-estrutura do Laboratório de XP. Mesmo assim, tivemos problemas com hardware quebrado e serviços instáveis. Na indústria e no governo, pode-se contratar uma pessoa ou um grupo para cuidar da administração da rede utilizada pela equipe de desenvolvimento. Em nossa experiência na Cultura Digital, no primeiro ano os desenvolvedores se revezavam no papel de administrador, sendo que cada um escolhia dias nos quais teria uma história reservada no planejamento só para cuidar de questões ligadas a suporte. O problema foi que estes ficavam sobrecarregados quando pessoas de outras equipes precisavam de apoio. No segundo ano, contratamos uma pessoa para cuidar somente da infra-estrutura e observamos que uma pessoa da equipe de desenvolvimento pôde investir tempo pareando com o admnistrador para criar pequenos programas que melhoravam seu ambiente de desenvolvimento colaborativo.

Em qualquer contexto, recomendamos fortemente o uso de software livre e de código aberto tanto 
para arcabouços, quanto servidores de aplicação e ferramentas. A qualidade das soluções existentes já foi comprovada pela comunidade, além do fato de que o código disponível é uma fonte de aprendizado que pode ser explorada pela equipe de desenvolvimento. O fato do código ser aberto permite com que a propriedade coletiva do código se estenda à toda comunidade mundial de desenvolvimento, que a equipe possa inspecioná-lo e melhorá-lo se necessário e que a comunidade ofereça suporte a esta atividade. Como sistema operacional recomendamos qualquer variante de GNU/Linux. Para serviços de repositório de código fonte recomendamos o SubVersion e para ambiente de desenvolvimento recomendamos o Eclipse. Que, como vimos, funciona até como um terceiro ajudante durante programação pareada, além de contar com excelentes ferramentas para refatoração automatizada. Este padrão é chamado de Use Software Livre.

Uma parte importante da infra-estrutura, que varia conforme as tecnologias adotadas e a estruturação dos servidores usados pela equipe, é o script de build. Dependendo do caso, ele pode ser responsável por compilar a aplicação, rodar testes automatizados, atualizar automaticamente um ambiente de testes e até mesmo colocar releases pequenos devidamente identificados no repositório em um ambiente de produção. Criar este script o quanto antes e com a ajuda de um treinador é recomendado. Observamos que uma vez que o script está feito, até mesmo desenvolvedores com pouca experiência podem se beneficiar do seu uso, este padrão é chamado de Script de Build.

Se pensarmos o código fonte como um espaço freqüentado diariamente pela equipe de desenvolvimento, compreendemos a importância de estabelecer um Padrão de Codificação o quanto antes para estabelecer toda infra-estrutura base necessária para começar um projeto. O Eclipse pode ser usado como um bom aliado para garantir o padrão de codificação adotado, pois conta com um plug-in que ajuda a gerá-lo, compartilhá-lo e mantê-lo. Na Paggo, o padrão de codificação era discutido em reuniões, na maior parte dos casos, sugerido por desenvolvedores com mais experiência e colocados em um radiador de informação chamado "Combinados da Equipe". Foi simples ensinar o padrão e praticá-lo durante sessões de programação pareada. Chamar o padrão de "Combinado" e ser flexíveis quanto a sua adoção fez com que ele fosse mais fácil de absorver por membros da equipe menos experientes. É uma maneira de adaptar o padrão ao contexto brasileiro, já que somos mais suscetíveis a seguir um combinado do que uma regra.

\subsubsection{Padrões para o planejamento da primeira experiência prática}

O próximo passo é aplicar XP em um projeto. Assim que soubermos qual será o projeto, entramos na etapa do aprendizado durante a qual as pessoas estão amadurecendo a prática da metodologia. Recomendamos que este projeto inicial, no qual acontecerá a etapa mais importante do aprendizado, tenha duração média. Em contextos onde os desenvolvedores estão presentes todos os dias, 3 meses são o suficiente para aprender XP. Porém, tanto no caso da Paggo quanto na Cultura Digital, o aprendizado se estendeu por mais de um projeto e durou 6 meses e um ano, respectivamente. No caso da Paggo, por razões financeiras, o meta-treinador não estava presente todos os dias, podendo acompanhar a equipe somente de dois a três dias por semana. Na Cultura Digital, onde o meta- 
treinador tinha outras responsabilidades e estava muito ausente, observamos que a equipe demorou mais tempo para amadurecer (as trocas constantes de metade dos desenvolvedores da equipe também não ajudaram).

Já na academia, dependendo da carga horária, disciplinas podem ter duração de quatro meses (para alunos interessados em aprender a usar XP) a um ano (para aqueles que pretendem se especializar no papel de treinadores). Recomendamos o formato de duas aulas semanais, de duas a três horas no mínimo. É importante incentivar a presença dos alunos, o padrão Almoço eXtremo é uma boa tática para se adotar. Além disso os alunos devem investir mais horas semanais no desenvolvimento (e para isso é importante ter acesso ao laboratório fora do horário das aulas).

Em qualquer contexto, a carga de trabalho deve levar em conta o padrão Trabalho Energizado. Uma boa carga didática na academia é de 8 horas semanais. No nosso caso, alunos conseguiram manter suas responsabilidades em outras disciplinas e se dedicar ao projeto sendo desenvolvido no laboratório. Em empresas no Brasil, devido ao contexto econômico, é normal que desenvolvedores estejam dispostos a trabalhar horas extras, em muitos casos sem remuneração. Na Paggo observamos que em épocas estressantes desenvolvedores estavam dispostos a trabalhar mais. O fato de que estagiários não estavam presentes em tempo integral encorajava-os a colocar horas extras. Recomendamos que esta prática não se torne a norma, pois compromete o trabalho energizado, é o anti-padrão Excesso de Hora Extra.

Em empresas e no governo é desejável que o projeto inicial seja fruto da aplicação do padrão Primeiro Planejamento VIP. Neste caso, recomendamos que o enfoque seja em desenvolver um projeto piloto interno durante o período de aprendizagem da metodologia. Este é o padrão que chamamos de Projeto Piloto. Em alguns casos porém, principalmente com clientes externos, isso não será possível, sendo importante que o cliente entenda as implicações de um contrato de escopo negociável. A equipe XP garante a entrega das funcionalidades mais importantes para o cliente nos primeiros releases, porém durante o aprendizado é altamente provável que algumas histórias tenham que ser descartadas e releases re-planejados devido a erros de estimativa.

$\mathrm{Na}$ academia, é importante que os alunos estejam engajados em projetos realistas. Recomendamos que projetos reais sejam desenvolvidos com parceiros da Universidade e distribuídos como software livre e de código aberto. Diferentes grupos de alunos podem continuar o desenvolvimento destes projetos em instâncias diversas da disciplina. Em cada instância, clientes planejam um tema que possa ser desenvolvido por completo durante um semestre. São os padrões Use Projeto Real e

\section{Adote Projeto Continuado.}

O padrão Ciclo de Estação define como um primeiro jogo do planejamento pode acontecer com clientes para que um tema seja selecionado e desenvolvido durante a próxima etapa, de amadurecimento do aprendizado de XP. Nesta etapa inicial, é importante que o planejamento leve em conta a inexperiência da equipe e adote o padrão Folga para que deslizes possam ser recuperados. O padrão Fase de Exploração é uma boa oportunidade para que a equipe de desenvolvimento possa enten- 
der as histórias do tema explorado. Vale mencionar que Histórias é um padrão de como capturar requisitos de um sistema. O padrão Spyke permite que desenvolvedores explorem as possibilidades tecnológicas de domínio da aplicação a ser desenvolvida. Recomendamos que o treinador participe de programação pareada com desenvolvedores e ajude-os a criar spykes, podendo introduzir tópicos como testes e refatoração em código que poderá ser descartado. Além disso, construir o sistema utilizando arcabouços livres e de código aberto como base (como XUnit, Ruby on Rails, Hibernate2, VRaptor e outros) é uma excelente idéia. Muitos desses arcabouços foram criados levando desenvolvimento ágil em consideração e a quantidade de código que pode ser reutilizado é enorme, chamamos este padrão de Use Arcabouços Livres. A maioria dos arcabouços recomendados contam inclusive com código de testes que pode servir de exemplo para o aprendizado. Nota-se que alguns programas livres e de código aberto não contam com bases de testes e podem ser complicados de modificar. Em nossa experiência na Cultura Digital tivemos muitos problemas devido ao fato que tanto o código do Drupal quanto do TikiWiki são Grandes Bolas de Lama [FY00].

Um anti-padrão interessante que observamos na última fase da etapa inicial de aprendizado de XP chamado Sem as Bases [FKG07] descreve como equipes enfrentam dificuldades para começar um projeto sem uma base de código. Desenvolvedores em equipes maiores tem problemas para integrar partes de um sistema ou até escrever testes quando não existe uma base de código sobre a qual se pode trabalhar. É difícil para pares se revezarem pois o par que começou a codificar um componente oferece resistência em deixar outros pares trabalharem nele com medo do que poderão pensar do seu código ou dos seus testes, ou até porque o par quer continuar o desenvolvimento do código que começou a construir. Coordenar tarefas é complicado, especialmente para a história de bootstrap, a primeira história que uma equipe implementa [And01]. Conseguir que uma equipe trabalhe em paralelo é complicado já que muitas histórias dependem de outras que podem não ter sido desenvolvidas.

Notamos que o problema é fácil de resolver. Recomendamos quatro alternativas. A primeira é dividir histórias grandes e, principalmente, a história de bootstrap usando Historiótipos [Mes04], uma linguagem de padrões que define diferentes tipos de histórias ${ }^{2}$.

Pode-se também construir a aplicação sobre uma base de código de software livre e de código aberto existente. É o que fazemos atualmente no Laboratório de XP, onde projetos como Colméia, Borboleta e Archimedes já entram no seu terceiro ano. Nestes casos, observamos que a base de código com testes e design simples funciona como uma excelente ferramenta de aprendizado.

Outra opção é desenvolver o código de bootstrap com uma equipe pequena. Adotamos esta estratégia nos cursos médios da AgilCoop, nos quais alunos contam com uma base de código inicial desenvolvida pelos treinadores.

\footnotetext{
${ }^{2}$ Historiótipos definem quatro tipos diferentes de histórias concretas que (1) ajudam a montar a infra-estrutura (montar o servidor de integração contínua, configurar o ambiente de desenvolvimento, aprimorar o script de build ou até mesmo pesquisar tecnologias novas), (2) criam nova funcionalidade no sistema, (3) alteram funcionalidade existente e (4) criam novas regras de negócio.
} 
Em outros contextos, pode-se fazer uma reunião com a equipe onde o design e a metáfora de uma primeira arquitetura são discutidos e depois permitir que um par ou sub-grupo de desenvolvedores mais experientes codifiquem rapidamente as classes base do modelo de negócios.

Também é possível que a prática de testes seja introduzida somente após existir uma base de código, de maneira que desenvolvedores sintam menos medo de compartilhar o seu código inicial.

\subsection{Aprendizado através da repetição prática - Amadurecimento da metodogia}

Após a etapa inicial de aprendizado, entramos em um ciclo de iterações no qual a equipe vai amadurecer seu conhecimento da metodologia através da repetição das práticas. Esta etapa normalmente termina quando a equipe tem autonomia para conduzir seu próprio processo independente de um treinador externo.

Diferentes estratégias podem ser utilizadas. Observamos que é eficiente adotar todas as práticas primárias desde o princípio quando a equipe é relativamente experiente; na academia esta é a melhor opção. Podemos também adotar práticas aos poucos. No caso de equipes menos experientes, essa é a estratégia recomendada, é o padrão Pequenos Passos. Neste caso, é importante levar em conta a dependência que existe entre algumas práticas e acompanhar o processo de adoção com o uso de métricas ágeis [Kre02]. A experiência de um bom treinador é valiosa na hora de decidir sobre a adoção de práticas ou métricas.

Seja qual for a estratégia adotada é muito importante que o treinador crie um ambiente no qual a equipe de desenvolvimento participe ativamente da construção metodológica, podendo tirar suas dúvidas e expor suas críticas, chegando até mesmo a propor alterações ao modo como as coisas estão sendo feitas. Toda informação relevante ao projeto deve chegar à equipe de desenvolvimento. Valorizar a comunicação é valorizar a opinião das pessoas mais importantes no processo de produção de software: os desenvolvedores. Beck [Bec99] comenta que o desenvolvedor é a figura central da metodologia e Coplien [CH04] reconhece este padrão como Desenvolvedores Controlam o Processo. Uma equipe de desenvolvimento realmente engajada na mudança metodológica é a chave para o sucesso.

Em nossa experiência na Cultura Digital, observamos que o processo de adoção de XP ocorreu muito lentamente. A prática de testes, por exemplo, só foi implantada um ano e meio após a equipe começar sua transição metodológica. Chamamos este anti-padrão de Passos Pequenos Demais, ele pode ser resolvido tanto com a presença mais constante de um treinador, que deve garantir que o ritmo de evolução das práticas se mantenha razoável, quanto com o padrão Desenvolvedores Controlam o Processo. Na nossa experiência, a velocidade de mudança na Cultura Digital acelerou consideravelmente depois de uma reunião na qual o treinador e os desenvolvedores chegaram a um acordo de que os próprios desenvolvedores deveriam propor alterações e melhorias ao processo, ao invés de esperar que o treinador ou o líder da equipe propusessem a maneira como eles deveriam trabalhar. 


\subsection{APRENDIZADO ATRAVÉS DA PRÁTICA - AMADURECIMENTO DA METODOGIA 101}

Já vimos que o padrão Retrospectivas encoraja a discussão sobre o processo adotado pela equipe. Para que um ambiente de melhoria e aprendizado contínuo seja a norma, retrospectivas providenciam um momento de reflexão necessário. Recomendamos fortemente que durante esta etapa do aprendizado retrospectivas sejam realizadas com freqüência. Segundo Cockburn [Coc02], este padrão é fundamental para ajudar o time a encontrar o processo que melhor se adapta ao seu contexto local.

Um anti-padrão curioso relacionado a esta etapa se chama Formato Formal [KH04]. Ele ocorre quando uma equipe adota e fixa as práticas de XP exatamente como indicado na teoria. O problema é que se esquece de adaptá-las para funcionarem melhor em um contexto e não se cria um ambiente de melhoria contínua. A solução é compreender que XP pode ser uma metodologia heurística além de um simples método a ser adotado.

\subsubsection{Padrões de treinamento}

Vimos que ambos os papéis de treinador e cliente são complexos e exigem dedicação. Alguns padrões observados em nossos estudos podem ser úteis para auxiliar as pessoas que preenchem estes papéis durante a etapa de amadurecimento no aprendizado de XP.

Em qualquer contexto, em especial durante o começo de projetos de aprendizado, recomendamos que o treinador adote o padrão Treinador Também Programa. No início, ainda mais com desenvolvedores pouco experientes e sem conhecimentos de desenho de arquiteturas orientadas a objetos, é importante que o Treinador participe de sessões de programação pareada e ajude os desenvolvedores a implementar o sistema. Em nossa experiência na Paggo, foi valioso tanto parear com desenvolvedores mais experientes para avançar em questões mais complexas, quanto parear com estagiários para ensinar conceitos básicos. No Laboratório de XP, em especial no projeto Cigarra, parear com os alunos era importante para mantê-los concentrados nas tarefas que estavam desenvolvendo. Neste contexto, observamos que, talvez pelo período de tempo que passa entre uma aula e outra ou até mesmo pela inexperiência de alguns com projetos reais, alunos tendem a divagar em suas tarefas e perder a visão geral do projeto. O treinador deve sempre estar atento a alunos que perderam o rumo, e ajudá-los a retomar o enfoque no desenvolvimento.

Por outro lado, o papel do treinador quando atuando como mentor durante sessões de programação pareada não é resolver todos os problemas e sim incentivar que os próprios desenvolvedores reconheçam soluções, oportunidades para simplificar o sistema e possíveis problemas para testar. Este padrão se chama Mostre o Caminho. No caso de equipes com pouca experiência em arquitetura de sistemas orientados a objetos, muitas vezes desenvolvedores implementam soluções que não seguem padrões de projeto documentados na literatura. Ao invés de explicitar um padrão que pode ser aplicado na arquitetura, recomendamos que treinadores ensinem alguns padrões para a equipe, escrevam testes para evidenciar problemas e deixem que a própria equipe, em seu tempo, reconheça oportunidades de aplicar um padrão de projeto. O padrão O Suficiente recomenda que, 
para facilitar o aprendizado de um conceito difícil, treinadores dêem apenas uma breve introdução e disponibilizem outras informações para quando as pessoas estiverem prontas. Uma alternativa para melhorar o aprendizado de práticas mais complexas como testes e refatorações é incentivar membros da equipe a participarem de um Coding Dojo na sua área.

Um padrão que foi muito valioso em nossa experiência foi Diários de um Treinador. Este sugere que o treinador mantenha um diário no qual pode anotar situações observadas e refletir sobre intervenções necessárias ou questões que precisam ser discutidas com membros da equipe. Tanto no Laboratório de XP quanto na Paggo mantivemos um diário onde anotávamos nossas reflexões após um dia de trabalho. Reler estas anotações mostrou-se valioso para direcionar as intervenções.

Para motivar a equipe, o padrão Pequenos Sucessos sugere que o treinador comemore até mesmo os pequenos avanços obtidos. Realizar pequenas celebrações pode melhorar muito a moral dos desenvolvedores. Na Paggo levamos um bolo para comemorar o dia em que conseguimos integrar nossos primeiros testes. Também realizavamos um Happy Hour após releases. Na Cultura Digital o script de build, após colocar um release em produção, até mesmo sugeria aos desenvolvedores que comemorassem com cerveja. O ambiente informal deste padrão é uma excelente oportunidade para que o treinador converse com membros da equipe individualmente sobre suas percepções e opiniões quanto à transição pela qual estão passando.

No Laboratório de XP, o dia no qual as equipes apresentam seus releases sempre conta com um clima festivo e inclui o Almoço eXtremo. O almoço é um bom padrão para incentivar alunos a comparecerem às aulas. Por mais que alguns sejam muito dedicados, em todos os anos observamos outros que faltam muito, especialmente em equipes maiores. Envolver refeições em eventos, cursos e reuniões é uma maneira de atrair participantes e providenciar uma oportunidade de interação com equipes passando pela experiência de aprendizado em um ambiente mais descontraído. Na Paggo, um café da manhã mensal incentiva a equipe a chegar mais cedo e é usado como uma oportunidade para todos se envolverem melhor com o domínio de negócios da empresa, contando com apresentação de notícias ou discussões sobre tendências de mercado diretamente com clientes e proxys. Este é o padrão Inclua Comida.

Valorizar o feedback veloz é muito importante para que a equipe possa realmente ser ágil, até mesmo no aprendizado de XP. Métricas auxiliam a entender o andamento do projeto. Encontrar maneiras eficazes de avaliar o processo e a equipe de desenvolvimento não é uma tarefa simples. Além disso, alguns dos possíveis problemas não são facilmente reconhecidos a partir de dados quantitativos. Recomendamos que a pessoa assumindo o papel de acompanhador tenha apoio constante para que métricas evidenciem aquilo que a equipe precisa perceber. A dissertação de mestrado de Danilo Sato [Sat07] como parte do trabalho do nosso grupo de pesquisa demonstra como fazer uso eficaz de métricas em projetos que utilizam métodos ágeis e conta com um catálogo de métricas que podem ser utilizadas para evidenciar deficiências nas diferentes práticas de XP como por exemplo: Total de Horas Pareadas, Duração da Iteração, Número de Commits, Total de Builds por Dia, Porcentagem 


\subsection{APRENDIZADO ATRAVÉS DA PRÁTICA - AMADURECIMENTO DA METODOGIA 103}

dos Testes de Aceitação Passando, Número de Defeitos, Total de Histórias Entregues, Número de Mudanças na Iteração e Número de Horas Extras. Este é o padrão Métricas Ágeis.

Apoiar o Cliente, ou proxys, também é uma tarefa importante para o treinador. Envolvimento Real com o Cliente envolve a participação ativa deste papel em jogos do planejamento, paposem-pé e avaliação de releases. Para isso, o padrão Seja Paciente sugere que o cliente esteja pronto para re-planejar e re-priorizar histórias das primeiras iterações de uma equipe que está aprendendo, já que a probabilidade de erros de estimativas e de defeitos surgirem é mais alta neste período.

Nos contextos industriais e governamentais, quando o treinador é contratado como um consultor externo, o anti-padrão Resistência ao Meta-Treinador indica que é natural que a equipe questione a importância deste ator, já que enxergam o investimento em uma pessoa externa como evidência de falhas internas. Neste caso, é importante deixar claro que o papel de meta-treinador é temporário e que o quanto antes a equipe se apropriar da metodologia, antes o meta-treinador poderá completar o seu trabalho. Este argumento incentiva a equipe a dominar XP. Também recomendamos que meta-treinadores diminuam a freqüência de sua participação ao longo do tempo.

Em contextos acadêmicos, alguns padrões específicos podem auxiliar o treinamento, como Lista de Presença que sugere que alunos tenham que assinar uma lista quando comparecem às aulas. Ao levar a participação em conta na hora de avaliar o aluno, incentivamos sua presença nas aulas. Mesmo assim observamos que muitos faltam durante o início do semestre e querem repor suas faltas no final. Nestes casos sugerimos o padrão Tempo Extra que permite que estes alunos reponham créditos relacionados a presença se dedicando a tarefas importantes para finalização dos projetos em tempo extra, fora das aulas fixas do laboratório. Além destes, o uso de uma lista de e-mails e um Wiki auxiliam o treinador a manter um diálogo contínuo com a sua equipe. Observamos no projeto Cigarra que a lista de e-mails permitiu que jogos do planejamento durassem uma aula mais todo o tempo até a próxima aula, no qual histórias e tarefas eram discutidas via e-mail. Este é o padrão Lista de Discussão.

\subsubsection{Padrões de planejamento contínuo}

Vimos que o projeto inicial de aprendizado pode ser planejado como um tema de um ciclo de estação. Porém é bem possível que uma equipe aprendendo XP passe por mais do que um ciclo de estação. Neste caso, é sempre importante contar com a fase de exploração e o apoio de spykes para que o planejamento mais detalhado seja realizado com as informações necessárias em mente.

O planejamento detalhado de uma iteração acontece durante o chamado Ciclo Semanal. Na verdade uma iteração pode conter alguns destes ciclos. O importante é que eles sejam utilizados para entender como anda o projeto e eventualmente fazer ajustes ou no escopo ou na data de entrega de um release. Observamos que o ciclo semanal não dura exatamente uma semana. Principalmente no início do aprendizado, pode ser importante fazer com que este ciclo tenha duração maior, de até um mês, de maneira que a equipe não fique sobrecarregada com o investimento de tempo implícito 
nas reuniões de planejamento e releases. Em nossa experiência na Paggo, começamos com ciclos de um mês e reduzimos para duas semanas, porém cada sub-equipe com ciclos descompassados. Na Cultura Digital, começamos com ciclos de uma semana, mudamos para duas semanas e atualmente empregam-se ciclos semanais, sempre começando na terça-feira. Na Academia, uma semana é muito pouco se considerarmos a carga didática recomendada para o Laboratório de XP, de maneira que faz mais sentido que este ciclo tenha duração de um mês.

No planejamento, seja ele o semanal ou de estação, o padrão Histórias recomenda um formato para que requisitos funcionais sejam capturados pela equipe. As Estimativas devem ser feitas com apoio de toda a equipe de desenvolvimento, é importante porém que exista tempo para que os desenvolvedores se acostumem com o conceito e aprimorem suas estimativas. Responsabilidade Aceita implica que o desenvolvedor responsável por uma história aceite-a voluntariamente e concorde com a estimativa anotada. Durante os ciclos semanais, o padrão Clima de Ontem recomenda que o acompanhador compare as estimativas com o tempo real gasto em tarefas e declare qual a velocidade de produção de uma equipe. É normal que a velocidade de um projeto aumente com o passar do tempo e com a familiarização com as estimativas. Principalmente no início de um projeto, incluir Folga no planejamento é importante para que a equipe não fique desmotivada ao errar estimativas, oferecendo uma oportunidade de reutilizar o tempo de folga em tarefas que demoram mais do que o estimado.

Para auxiliar o planejamento e acompanhamento de um ciclo, recomendamos o uso do padrão Quadro de Histórias que sugere que um espaço físico seja separado para que toda equipe e colaboradores externos possam visualizar quais histórias estão sendo desenvolvidas, quais foram finalizadas e quais ainda faltam para terminar um release. Este padrão pode ser reconhecido na prática backlog do Scrum [SB01, SBG07].

Também para auxiliar na concepção de histórias, principalmente como apoio a um cliente proxy, recomendamos aplicar o padrão Personas [SBG07]. Personas são pessoas fictícias que representam um grupo de usuários do sistema. São criadas pela equipe de desenvolvimento para serem atores nas histórias. O uso de personas ajuda a equipe a considerar diferentes casos de interação com o sistema sendo desenvolvido, que normalmente são esquecidos quando se pensa em um único tipo de usuário.

Já vimos que é importante que o planejamento sustente o padrão de Trabalho Energizado. Para enfatizar esta prática na indústria e no governo recomendamos o uso do padrão Tempo de Estudo que pode ser organizado como grupos de estudo continuado. Na Paggo, ao ouvir da equipe a demanda por tempo para se aprofundar em novas tecnologias, em um primeiro momento incluímos histórias de estudo no planejamento. Cada desenvolvedor poderia se especializar nas tecnologias que lhe interessavam pegando algumas histórias de estudo no ciclo semanal [FKT05]. Atualmente, a Paggo reserva uma hora por dia para que seus desenvolvedores exercitem ócio criativo e um dia reservado para estudos no seu ciclo, que dura duas semanas. Na Cultura Digital, também fizemos uso de histórias de estudo. Tempo de estudo pode evoluir para exploração quando começa a envolver 


\subsection{APRENDIZADO ATRAVÉS DA PRÁTICA - AMADURECIMENTO DA METODOGIA 105}

codificação de spykes. Na Cultura Digital, histórias de estudo eram usadas quando sentíamos que ainda não existia informação suficiente sobre uma tecnologia para colocá-la em prática.

Um bom padrão para observar se o ritmo de trabalho está sustentável é o Humorômetro. O humorômetro, ou calendário niko-niko [Sat07], é um cartaz onde membros de equipe anotam o seu humor. Se o calendário estiver marcando muito mau humor pode ser um sinal de que o ritmo não está sustentável.

Na academia, acontece o abandono de alunos da disciplina, isto pode implicar que a equipe desfalcada precise ajustar-se para manter o trabalho energizado. Um anti-padrão neste contexto, chamado Abandonar o Navio, é não contar com alunos que cancelam sua matrícula. Se algum aluno precisar abandonar a disciplina é importante que o cliente re-priorize histórias, reduzindo o escopo, e que a equipe conte com mais ajuda de seu treinador. Pode-se até mesmo fazer com que equipes maiores cedam um integrante para a equipe desfalcada. Este anti-padrão também é observado em cursos médios.

No início do aprendizado, quando ainda não existe maturidade na prática de testes, é muito provável que os releases pequenos não sejam de altíssima qualidade. Um bom padrão para manter a equipe motivada é negociar com o cliente um Bug Fix Release. Na Paggo, após uma entrega particularmente defeituosa onde o cliente se recusou a aceitar qualquer uma das histórias, negociouse uma iteração mais curta (o ciclo duraria uma semana) com o único objetivo de testar melhor a aplicação e eliminar os defeitos observados. Posteriormente, descobrimos que um único defeito que fora introduzido na véspera do release em uma parte da aplicação fora da cobertura de testes tinha "quebrado" todo o sistema. Consertado o defeito, investimos o resto do tempo para aprimorar os testes. Na Cultura Digital, também realizamos alguns bug fix releases.

Já discutimos os padrões Retrospectiva e Papó-Em-Pé. Recomendamos fortemente seu uso para poder adaptar o planejamento de acordo com o feedback constante da equipe. Um efeito colateral ligado à cultura brasileira observado na Paggo foi o uso da ferramenta de retrospectiva para fofoca e discussões pessoais. Quando as pessoas esquecem de participar da retrospectiva acreditando que todos na equipe fizeram o seu melhor o anti-padrão Fofoca pode se manifestar. Após um dia no qual o desenvolvedor sênior saiu mais cedo pois tinha sido avisado que a equipe poderia relaxar antes de um feriado, porém sem comunicar o fato para o resto da equipe, o nosso quadro de histórias, também usado para guardar anotações para retrospectiva, transformou-se em uma guerra de reclamações. O padrão Reunião de Lavar Roupa Suja mostrou-se importante para solucionar este caso. Criando um ambiente onde questões pessoais poderiam ser resolvidas a equipe encontrou uma maneira de acertar suas diferenças [FKT05]. Não recomendamos que este padrão seja utilizado com freqüência pois é emocional, intenso e exaustivo. 


\subsubsection{Padrões de design}

O padrão Design Incremental sugere que exista investimento contínuo na arquitetura e projeto de uma aplicação. Adotá-lo é extremamente importante para manter o design de um sistema simples de fato. Porém, infelizmente, nem sempre podemos contar com a experiência necessária para guiar o desenho de uma arquitetura em uma equipe, especialmente devido à economia Brasileira. Vimos que o treinador deve ajudar neste caso. Aplicar os seguintes padrões é válido em qualquer contexto.

A Metáfora é um padrão simples que muitas vezes é negligenciado, sem motivo, no ensino de XP. Para criar uma boa metáfora, é importante que o cliente se esforce para ensinar aos desenvolvedores os termos de domínio do negócio e que os desenvolvedores ensinem ao cliente termos relativos às tecnologias utilizadas. No projeto Mico, a metáfora do algoritmo genético foi facilmente assimilada pela equipe e os clientes. Na Paggo, reuniões periódicas com o cliente que falava sobre o domínio de negócios da empresa, ajudaram muita na criação de uma metáfora. A linguagem por trás de XP pode ser usada na construção de uma metáfora que auxilia no aprendizado da metodologia, evoluindo junto com seu uso.

A Propriedade Coletiva do Código é um padrão simples de ensinar e adotar desde o início do aprendizado. Observamos um pouco de resistência proveniente dos Velhos Dinossauros, porém é importante que todos compreendam que quanto mais pessoas na equipe conhecerem todo o código, melhor. Nas experiências observadas, equipes que tiveram que trocar desenvolvedores e não praticavam propriedade coletiva do código tiveram mais problemas. O anti-padrão Não Sou Necessário Aqui ocorre em contextos industriais e governamentais quando a prática de propriedade coletiva funciona tão bem que uma pessoa que se ausenta por questões pessoais ou de saúde sente-se desnecessária ao retornar e verificar que a equipe não sentiu sua falta [KH04]. Como solução, recomendamos que o treinador converse com a pessoa e ajude-a a redescobrir seus objetivos pessoais dentro da organização.

As práticas de modelagem ágil são bons padrões para auxiliar o ensino de design incremental [Amb02]. Reunião de Modelagem sugere que após o planejamento de um ciclo, desenvolvedores se encontrem e utilizem um Quadro Branco para pensar sobre a arquitetura do sistema, desenhando diagramas UML. Na Paggo, após o planejamento de uma iteração no qual uma das histórias do cliente requeria mudanças arquiteturais no sistema, uma reunião de modelagem mostrou-se útil para que todos chegassem a um acordo sobre como evoluir a arquitetura. Tarefas específicas foram criadas para refatorar o sistema e implementar a nova estrutura. No Laboratório de XP, equipes utilizam o quadro branco com freqüência para desenhar diagramas de classes e seqüência antes de implementar funcionalidades. Na Cultura Digital, os desenvolvedores mais experientes utilizaram algumas histórias de estudo para propor uma refatoração arquitetural do Estúdio Livre. Até mesmo pares podem se beneficiar de uma rápida reunião de modelagem antes de programar sua tarefa. $\mathrm{O}$ antipadrão Dono da Bola explicita o problema que ocorre naturalmente quando somente o treinador, ou desenvolvedores mais experientes, usam a caneta para desenhar no quadro branco durante estas reuniões [KH04]. Como solução recomendamos que o treinador incentive os desenvolvedores menos 


\subsection{APRENDIZADO ATRAVÉS DA PRÁTICA - AMADURECIMENTO DA METODOGIA 107}

experientes a anotar no quadro enquanto os mais experientes podem colaborar explicando conceitos e técnicas de Orientação a Objetos.

O padrão Refatoração sugere que qualquer oportunidade de melhorar o código fonte de um sistema seja explorada. Existem refatorações simples de ensinar, como as refatorações que envolvem renomear variáveis e métodos. Com o auxílio de ferramentas como o Eclipse, que automatizam os passos envolvidos em refatorações, alterando toda uma base de código, até as mais complexas podem ser realizadas por desenvolvedores menos experientes. Porém, observamos que a habilidade de reconhecer áreas no código onde é possível refatorar requer experiência. Sugerimos que a prática de refatorações simples seja adotada desde o início do desenvolvimento, refatorações mais complexas podem ser introduzidas com o passar do tempo.

Muitas vezes, observamos áreas de uma aplicação que "cheiram mal" ou poderiam ser melhoradas, porém por alguma razão achamos melhor não refatorá-las imediatamente. O padrão Limiar de Refatoração sugere que anote-se em um radiador de informação dois limites para o número de refatorações pendentes (um que pode ser ultrapassado eventualmente para deixar a equipe em alerta e outro que se ultrapassado deve implicar na realização das refatorações pendentes) em um sistema de maneira que a equipe sempre encontre-se confortável com a qualidade do código existente. O uso do Eclipse facilita a contabilização de refatorações pendentes, pode-se listar por exemplo todos os comentários que contém a palavra "TODO" 3.

O anti-padrão O Chefe Refatorou o Nosso Código se aplica em contextos governamentais e industriais quando existe um hierarquia entre os desenvolvedores [KH04]. Os menos experientes podem se sentir intimidados se os mais experientes refatorarem código criado por eles. Como solução recomendamos que se desenvolvedores mais experientes descobrirem oportunidades de refatorar código produzido por estagiários que esta oportunidade seja explorada em uma sessão de programação pareada onde aproveita-se para ensinar o processo e suas razões aos menos experientes.

As empresas e o governo devem investir em ao menos algumas pessoas bem qualificadas na equipe para garantir que a prática de design incremental e refatoração possam realmente ser aplicadas. $\mathrm{Na}$ academia, é importante que os pré-requisitos da disciplina sejam claros, recomendamos que as práticas de modelagem ágil e refatoração sejam exploradas em disciplinas introdutórias (por exemplo, Introdução à Programação e Introdução à Programação Orientada a Objetos) e que alunos com experiência no mercado participem das turmas. Em nossas observações, a participação de pessoas com experiência mostrou-se essencial para que uma equipe aprenda ambas as práticas.

\subsubsection{Padrões para aplicar no dia-a-dia}

Algumas práticas de XP são propostas para acontecer diversas vezes ao dia, todos os dias. Vimos que Integração Continua é importante para que uma versão funcional do sistema esteja sempre disponível. Esta prática é fácil de adotar no início do processo de aprendizagem. Ferramentas livres

\footnotetext{
${ }^{3}$ Do inglês: To do que pode ser traduzido como "a fazer".
} 
e abertas facilitam a vida de uma equipe de desenvolvimento providenciando repositórios de código fáceis de instalar e usar, além de automatizar o processo de verificar mudanças em um repositório ou integrar alterações feitas.

O padrão Repositório Único sugere que uma aplicação conte com somente um repositório. Este padrão depende muito do contexto para ser aplicado. Equipes que desenvolvem mais de um sistema podem ter mais de um repositório. Além disso, muitas vezes um repositório com arcabouços comuns a mais de um sistema faz sentido. Este padrão deve ser aplicado quando se trabalha com sistemas legados que estavam distribuídos em muitos repositórios. Quando sistemas legados estão sendo migrados, vale a pena aplicar também o padrão Implantação Incremental que, como já vimos, sugere que ambos o novo sistema e o sistema legado fiquem disponíveis durante o período de migração, que deve acontecer em pequenos passos. Recomendamos o uso de ambos estes padrões quando se lida com sistemas legados para conseguir lidar com sua complexidade natural.

O processo de Build Veloz deve acontecer várias vezes ao dia. Vimos que o script de build é uma ferramenta essencial, porém não basta desenvolvê-lo no início do projeto. O investimento em aprimorar o build também deve ser contínuo. Tanto na Paggo quanto na Cultura Digital nossos scripts também eram responsáveis por instalar versões das aplicações em ambientes de teste e produção. Ferramentas livres e de código aberto como o CruiseControl podem auxiliar na tarefa de incrementar o build para que ele possa até baixar todo o código novo integrado em um dia, rodar todos os testes e mandar e-mails para os responsáveis com o resultado. O script de build pode também coletar e publicar medidas de acompanhamento. Dominando estas tecnologias, é possível diminuir a freqüência dos pequenos releases para que eles aconteçam diariamente, é o padrão Implantação Diária. Este padrão pode ser facilmente adotado se o sistema desenvolvido é um sistema para a Web. Na Cultura Digital, nosso sistema de build automaticamente publicava todas mudanças realizadas em um dia no ambiente de testes, que está disponível na web. Desta maneira usuários podem auxiliar no processo de testes, podendo realizar testes de aceitação manuais de uma funcionalidade no mesmo dia em que ela foi implementada. Talvez por contar com estes testes manuais, a equipe tenha demorado tanto para realmente investir em testes automatizados. Recomendamos que este tipo de práticas se complementem.

Vimos que Programação Pareada é um padrão amplamente reconhecido e validado. Um antipadrão comum relativo a esta prática em contextos industriais e governamentais se chama Prisão de Pareamento e ocorre quando todo o tempo da equipe de desenvolvimento é reservado para programação pareada [KH04]. A solução é também separar algum tempo para as pessoas dedicarem a tarefas pessoais. Na Paggo reservávamos três sessões de pareamento por dia. Membros da equipe tinham uma hora de manhã e uma hora após o almoço para tratar de questões pessoais. Nestes contextos, é muito útil utilizar a programação pareada como ferramenta de seleção de novas pessoas na equipe. Na Paggo, entrevistas são realizadas de forma que pretendentes a uma vaga participem de sessões de programação pareada com a equipe. Na academia, recomendamos que o ensino desta técnica seja incluído em disciplinas introdutórias e incentivado através de trabalhos em pares. Outro 


\subsection{APRENDIZADO ATRAVÉS DA PRÁTICA - AMADURECIMENTO DA METODOGIA 109}

anti-padrão relacionado a programação pareado se chama Panelinha e sugere que pares que nunca se revezam prejudicam o resto da equipe. Uma solução pode ser a adoção de uma "Matriz de Pareamento" como métrica para evidenciar este comportamento, além de incentivar o revezamento entre os pares. Na indústria e no governo, observamos que incentivar pares entre desenvolvedores de mesmo nível de conhecimento é recomendado. Pareamentos entre níveis diferentes são mais úteis para mentoring porém podem ser cansativos para o desenvolvedor mais qualificado e estressantes para seu par. Chamamos este padrão de Mantenha o Nível.

O padrão Desenvolvimento Dirigido por Testes implica que testes sempre serão escritos para cobrir todo o código da aplicação. Na nossa experiência esta é uma das práticas mais difíceis de ensinar, tanto pela inexperiência de desenvolvedores quanto pelo fato de que defeitos são considerados normais em software, mas ela é essencial. Infelizmente, no contexto brasileiro muitas vezes a qualidade não determina o sucesso. Muitas "gambiarras" permanecem como solução por preguiça; é uma incrível capacidade dos brasileiros de se adaptarem a dificuldades. Observamos um comportamento cético quanto aos testes na equipe da Cultura Digital, talvez por que defeitos sempre são evidenciados por testes manuais feitos pelos usuários dos sistemas. Recentemente, a descoberta de um defeito de segurança grave fez com que alguns desenvolvedores começassem a compreender o valor de testes automatizados. Na Paggo, nossos primeiros releases contavam com muitos defeitos. A prática de testes foi lentamente adotada. Observamos que, ao longo do tempo, com mais experiência e mais testes desenvolvidos, os desenvolvedores começam a dar valor a esta prática. Recomendamos que o ensino de testes seja introduzido no início do currículo acadêmico, inclusive podendo ser adotados para validação automática de exercícios-programa.

A dificuldade com os testes também é decorrência da falta de ferramentas que podem auxiliar o processo; até recentemente testes de aceitação de sistemas web eram muito complicados e trabalhosos de escrever. Atualmente, com ferramentas livres e de código aberto como o Selenium, esperamos observar uma maior adoção de testes de aceitação automáticos.

Para evidenciar a necessidade de testes, certa vez na Paggo observamos problemas com um dos releases e deixamos que a equipe resolvesse entregá-lo ao cliente mesmo assim. Usamos a decepção do cliente ao ver o sistema com defeitos para reforçar a importância de criar e executar testes automatizados.

O padrão Análise da Causa Inicial recomenda que após um defeito ser encontrado uma análise seja realizada para tentar determinar sua causa. Na maior parte dos casos, a causa é falha humana. Este tipo de análise se mostra importante nas primeiras iterações de uma equipe aprendendo XP podendo explicitar deficiências na prática de testes, programação pareada, refatoração e propriedade coletiva do código.

O padrão Código e Testes sugere que estes sejam os únicos artefatos permanentes mantidos pela equipe. Para adotá-lo é importante que testes automatizados e design incremental estejam funcionado bem. Recomendamos que este padrão só seja adotado após a equipe estar mais experiente e não ter 
medo de descartar outros artefatos gerados. Jogar fora os diagramas UML do design da arquitetura de um sistema apagando o quadro branco após uma reunião de modelagem pode incentivar a equipe a entendê-lo melhor e simplificar o código de maneira que ele fique claro e comunique a intenção do design.

Um anti-padrão que pode emergir da prática diária de espaço aberto e informativo se chama Espaço Aberto Demais e foi observado em contextos industriais e governamentais. Uma equipe que comunica de forma visível seus progressos e seus defeitos pode ser considerada uma ameaça. Ainda mais no contexto governamental brasileiro no qual, infelizmente, observamos como norma: o aparelhamento da máquina do estado, a incompetência de servidores indicados por razões políticas e a inércia de funcionários públicos. Ao tornar-se ágil e produtiva, uma equipe atrai a inveja de outros setores ou departamentos de uma organização; críticas indevidas podem atrapalhar o fluxo de trabalho. Como solução refatorada, recomendamos que o espaço seja aberto e comunicativo para dentro da equipe, mas conte com um certo isolamento do resto da organização. O padrão Firewall sugere que uma pessoa assuma o papel de intermediar a comunicação de uma equipe ágil com o resto da organização.

Finalmente, em contextos industriais se observamos resistência contínua provindo de Velhos Dinossauros mesmo após várias tentativas de contornar o problema, recomendamos o uso do padrão Demita-o. Durante o aprendizado na Paggo tornou-se claro que o desenvolvedor sênior não tinha interesse em aprender XP. Quando ele saiu da equipe observamos um avanço no aprendizado de todos. Desde então, alguns outros funcionários que não se adaptaram foram convidados a se retirar.

\subsection{Etapa final - A equipe desenvolve sua própria metodologia}

Após usar a metodologia durante várias iterações, a equipe deverá ter adaptado as práticas de XP e até mesmo adotado novas práticas. Este é o momento do meta-treinador se retirar e deixar a equipe guiar seu próprio processo de maneira independente. Existem alguns padrões que podem ajudar nesta etapa final do aprendizado.

Um anti-padrão comum neste momento se chama Complexo de Abandono [FKG07]. Este anti-padrão sugere a solução para o problema comum de não se alocar ninguém para o papel de treinador quando o meta-treinador deixa uma equipe. Quando isso acontece não recomendamos que uma só pessoa, possivelmente um desenvolvedor mais experiente, seja sobrecarregado com as tarefas do treinador. Até mesmo em contextos controlados como na academia observamos casos de alunos que atuavam como treinadores terem que desistir da disciplina. Também observamos que na maioria dos casos o desenvolvedor mais experiente não é a melhor escolha para preencher o papel de treinador. Como solução propomos que a equipe adote o padrão Defensor da Corte [Jac04] elegendo algumas pessoas, entre as que estão mais confortáveis com os valores, princípios e práticas de XP, para guiar a equipe no refinamento de sua metodologia de trabalho. Recomendamos ainda que mais de um campeão aceite esta responsabilidade e que o papel seja revezado entre membros da equipes como 
sugere o padrão Treinador da Semana [FKT05].

Os padrões Continuidade da Equipe e Redução da Equipe sugerem que se mantenha junta a equipe que está funcionado bem. Porém, se o projeto já amadureceu o suficiente, a equipe pode ser reduzida sem perdas para a manutenção do sistema desenvolvido. Em uma organização grande sugerimos que pessoas que já passaram pelo processo de aprendizagem de XP em um projeto devem fazer parte de outras equipes que pretendem adotar a metodologia.

Se o projeto ainda precisa crescer, o padrão Em Fases sugere que, em um momento inicial, desenvolvedores mais experientes sejam contratados e que em outros momentos desenvolvedores menos experientes sejam agregados ao time. Em qualquer caso onde novas pessoas precisam ser incorporadas a uma equipe o padrão Time Auto-Selecionado deve ser adotado. Este padrão dita que a própria equipe participe do processo de seleção de novos membros, possivelmente através de sessões de programação pareada.

O padrão Retroperspectiva é útil neste momento. Ele sugere que uma grande retrospectiva seja realizada tentando observar todo um ano do processo. Ao invés de sugerir ações imediatas que podem ser adotas pela equipe, a retroperspectiva serve para que a equipe pense em perspectivas um pouco mais amplas e abstratas de como poderão evoluir no ano seguinte. Esta prática é valiosa para observar a quantidade de trabalho realizada em um grande período pela equipe, fazendo com que seja mais fácil para as pessoas abstraírem questões pessoais (evitando o anti-padrão Fofoca) e sugerirem melhorias levando em conta um contexto mais amplo.

\subsubsection{Observações Póstumas}

Como parte do nosso trabalho, também observamos como equipes se comportam depois de passar pela experiência de aprendizado de XP. No contexto acadêmico, observamos que alunos não tem tempo de atingir a etapa de amadurecimento em uma única instância da disciplina. Por esta razão, recomendamos que alunos interessados em se aprofundar no método capacitando-se para assumir o papel de treinador em ambientes industriais participem da disciplina por uma segunda vez, desempenhando o papel de treinador em alguma das equipes. Observamos que alunos que se especializaram como treinadores obtiveram mais experiência no uso da metodologia e estavam aptos a guiar uma organização pela transição metodológica para XP. Na Paggo e na Cultura Digital, realizamos visitas algum tempo após termos participado da experiência de ensino de XP para observar como as equipes estavam trabalhando.

O ambiente na Paggo demonstra como uma equipe pode construir um verdadeiro ambiente de aprendizado e melhoria contínua. Atualmente, a empresa conta com 55 pessoas (incluindo um call center). Destas, oito pares trabalham na equipe de desenvolvimento base, dois pares atuam na equipe de Web design e um par atua como clientes proxy dentro da empresa Oi, maior cliente da Paggo. Este par de clientes proxy é interessante pois cada um assume um papel: o Tradutor responsabiliza-se por coletar requisitos gerados na Oi e traduzi-los para a equipe de desenvolvimento e o Cobrador 
é responsável por garantir que pendências do lado do cliente serão resolvidas a tempo. O jogo do planejamento de cada grupo ocorre em uma única manhã por iteração, as iterações duram duas semanas e os desenvolvedores contam com 3 sessões de 2 horas diárias para programação pareada, além de uma hora reservada para o ócio criativo. A cada iteração, um dia é reservado para estudos e pesquisas; chama-se Tech Day. Estimativas são realizadas com precisão usando pontos relativos às sessões de programação pareada. O quadro de histórias ocupa todas as paredes do escritório. Os desenvolvedores relataram que a adoção de software livre e de código aberto foi essencial para garantir ainda mais agilidade à equipe. Por exemplo, eles utilizam a última versão disponível da base de códigos do MySQL (que não é considerada estável pela comunidade) sem medo e inclusive ajudaram a encontrar um defeito neste código. Vale comentar que a Paggo migrou de Oracle para MySQL em apenas 3 semanas (isto adotando a prática de trabalho energizado). Outra observação que comprova a agilidade da equipe foi seu último contrato com a Oi, que teve o escopo reduzido em $20 \%$ e a entrega antes da data prevista. O proprietário, os trabalhadores e os clientes da empresa estão completamente satisfeitos e a metodologia e o ambiente de trabalho são excelentes. Além disso, práticas ágeis são usadas em outros departamentos da empresa tais como Marketing e Relações com o Cliente.

Já na Cultura Digital, observamos que a equipe ainda está amadurecendo sua metodologia de trabalho. Notamos que esta experiência é peculiar por forçar a equipe a se reestruturar ano após ano. Porém, neste último semestre, já sem apoio do treinador, a equipe adaptou sua metodologia de trabalho incluindo a maioria das práticas de XP, estendendo-as para funcionar em um ambiente de colaboração com atores distribuidos geograficamente. As iterações são semanais, contando com um jogo do planejamento todas terças-feiras. A equipe estima suas tarefas em horas e não adota programação pareada sempre, mas com muita freqüência e algumas vezes acontece até mesmo programação pareada remota. Para incluir desenvolvedores distantes, o jogo do planejamento conta com apoio de ferramentas como o Skype, transmissão ao vivo de áudio e vídeo e uma sala de bate papo IRC. Além disso, a equipe mantêm um Wiki onde todos aspectos relacionados às práticas metodológicas são armazenados. Quando observam que uma nova prática emerge, eles rapidamente atualizam o Wiki para que todos desenvolvedores sejam notificados e também para que a comunidade de clientes saiba como estão trabalhando.

A interação com a comunidade de usuários dos portais desenvolvidos é muito interessante. A prática de personas por exemplo evoluiu ao ponto de que a equipe utiliza personas reais baseadas nos usuários que são mais ativos na comunidade. Além disso contam com o ambiente de desenvolvimento onde podem testar funcionalidades novas todos os dias (a atualização é automática), uma lista de discussão onde podem se relacionar com os desenvolvedores e ferramentas de listagem e acompanhamento de defeitos. Os desenvolvedores também escrevem relatórios mensais para explicar à comunidade o que foi desenvolvido em um release e mantêm um blog para descrever suas atividades e descobertas diárias. O manual de uso do portal é escrito com participação ativa da comunidade de usuários e demonstra a importância de documentação em projetos ágeis. Usar o Wiki para armaze- 
nar o manual é uma maneira de permitir com que ele evolua com agilidade e que todos usuários da comunidade possam colaborar na sua construção e atualização.

Entre as novas práticas, as duas que mais nos interessaram foram a Imersão eXtrema e o Tracker Bot. Na Imersão eXtrema, toda equipe se encontra em um ambiente externo no qual, durante uma semana, trabalham e convivem juntos, todos os dias, o dia todo. Este padrão se mostrou muito produtivo para integrar novos membros. Ele aumenta consideravelmente a capilaridade dos fluxos de comunicação de uma equipe, além de propiciar um ambiente de alta criatividade e produção, aumentando as possibilidades de encontrar-se defeitos e oportunidades para refatoração e simplificação do design de uma aplicação.

O padrão Tracker Bot sugere que, quando a equipe dominar o papel de acompanhador, suas funções devem ser automatizadas. Na Cultura Digital, um robô foi programado para estar sempre on-line no canal IRC. Ele recebe e relata informações do repositório de código fonte, do wiki, e dos desenvolvedores para gerar estatísticas usadas na avaliação do andamento do processo. Na Cultura Digital, algumas práticas ágeis também são usadas por equipes não ligadas ao desenvolvimento de software. Os três portais desenvolvidos continuam sendo atualizados com releases freqüentes e a comunidade de usuários está razoavelmente feliz com o uso que fazem dos sistemas no dia-a-dia e o progresso que observam a cada iteração.

\subsection{Práticas ágeis para trabalhar colaborativamente}

Observamos que algumas práticas ágeis podem trazer benefícios até mesmo para grupos que não estão programando. Os valores e princípios da Programação eXtrema podem ser aplicados em outros contextos de uma organização e observamos duas experiências práticas do gênero. Tanto na Paggo quanto na Cultura Digital outras equipes adotaram alguns dos padrões das metodologias ágeis para melhorar a maneira como trabalhavam.

Os valores e princípios de XP são genéricos o suficiente para serem aplicados em contextos além da programação de software. Comunicação, feedback, simplicidade, coragem e respeito são valores que podem melhorar qualquer tipo de trabalho. Os princípios, que são a base das práticas de XP, também podem ser usados para criar práticas de trabalho em outras áreas.

Em particular, observamos o valor de documentar requisitos como histórias. No primeiro ano do projeto da Cultura Digital, utilizamos histórias para explicitar requisitos das diferentes equipes. A cada quinze dias, representantes destas equipes se reuniam e apresentavam aos outros as histórias que tinham realizado e o backlog de pendências. Durante esta reunião, as equipes poderiam sugerir histórias umas às outras. Esta experiência foi válida para aumentar a comunicação em um grande projeto com mais de 80 pessoas distribuidas pelo país. Nos quase dois meses nos quais praticamos histórias nas diferentes áreas do projeto, elas foram valiosas para que todas as equipes tivessem uma visão comum do trabalho sendo realizado pelo resto da organização. A prática melhorou a comunicação e a prestação de contas entre as pessoas. Infelizmente, ao final do ano, o projeto 
passou por uma reformulação que criou o cargo de "coordenador" nas diferentes áreas. Isso criou um gargalo e acabou centralizando o processo de comunicação do grupo. Tentamos manter a prática de compartilhar histórias e fornecer feedback sobre o progresso nas diferentes áreas em uma lista de e-mails para a coordenação, porém esta tentativa não foi bem sucedida. Hoje em dia cada equipe não tem uma percepção clara do trabalho realizado pelas outras, por mais que algumas equipes se esforcem para relatar suas atividades usando relatórios mensais em Wikis e blogs. Notamos que a maior parte dos relatórios tem valor puramente burocrático pois são entregues como produtos ao Ministério.

$\mathrm{Na}$ Paggo, atualmente todas as áreas utilizam histórias para especificar seus projetos. Em áreas como marketing ou relações com o cliente as histórias contam com estimativas abstratas. Estas podem ser relativas a uma tarefa de cobrança de um colaborador após algum tempo ou até mesmo à data de quando alguém de fora da organização prometeu dar o retorno necessário para o andamento de um projeto. Todas as áreas contam com um quadro de histórias e cada história tem dois responsáveis. Em um jogo do planejamento, que ocorre a cada duas semanas, as diferentes áreas podem verificar quais tarefas foram realizadas e quais ainda estão pendentes. Se um desenvolvedor precisa de algo relacionado a um projeto da equipe de marketing, ele pode facilmente olhar o quadro de histórias desta equipe para saber o andamento do projeto.

O uso da prática de Histórias também implica no uso de versões modificadas das práticas de Ciclos e Jogos do Planejamento. Além disso, o papel do Cliente mostrou-se adaptável a outros contextos e as histórias são escritas por pessoas que assumem este papel nas diferentes áreas da organização. Em conjunto com o planejamento ágil pode-se também adotar métricas com facilidade. Na Cultura Digital, utilizávamos humorômetros para conhecer melhor o processo de oficinas.

A prática de planejamento ágil mostrou-se uma excelente aliada para a organização de eventos onde a equipe se encontrava para trabalhar em algum produto específico. Em específico, na organização de oficinas para os pontos de cultura, o planejamento ágil foi muito utilizado para que pudéssemos lidar com as eventuais mudanças de horários ou até mesmo lidar com as propostas de novas atividades feitas por pessoas dos pontos. A Figura 4.3 mostra um mural com o resultado do planejamento ágil de uma oficina da Cultura Digital aonde observa-se o cronograma de oficinas que podia ser atualizado para lidar com mudanças no plano.

Programação pareada também é uma prática que pode ser adaptada para outros contextos. Na Cultura Digital, por exemplo, a equipe de produção de vídeos experimentou fazê-lo e mostrou-se feliz com a prática. Na Paggo, todas tarefas de qualquer projeto sempre contam com dois responsáveis e são executadas, na sua grande maioria, em pares de modo que se alguém não estiver presente na empresa existe sempre uma pessoa que está acompanhando o trabalho sendo realizado.

A prática de Papo-em-Pé também se mostrou facilmente adaptável a outros contextos. Durante as "Oficinas de Conhecimentos Livres" da Cultura Digital muitas vezes a equipe se encontrava de manhã e realizava um papo-em-pé para saber melhor como estava a oficina. Na Paggo, todas as 


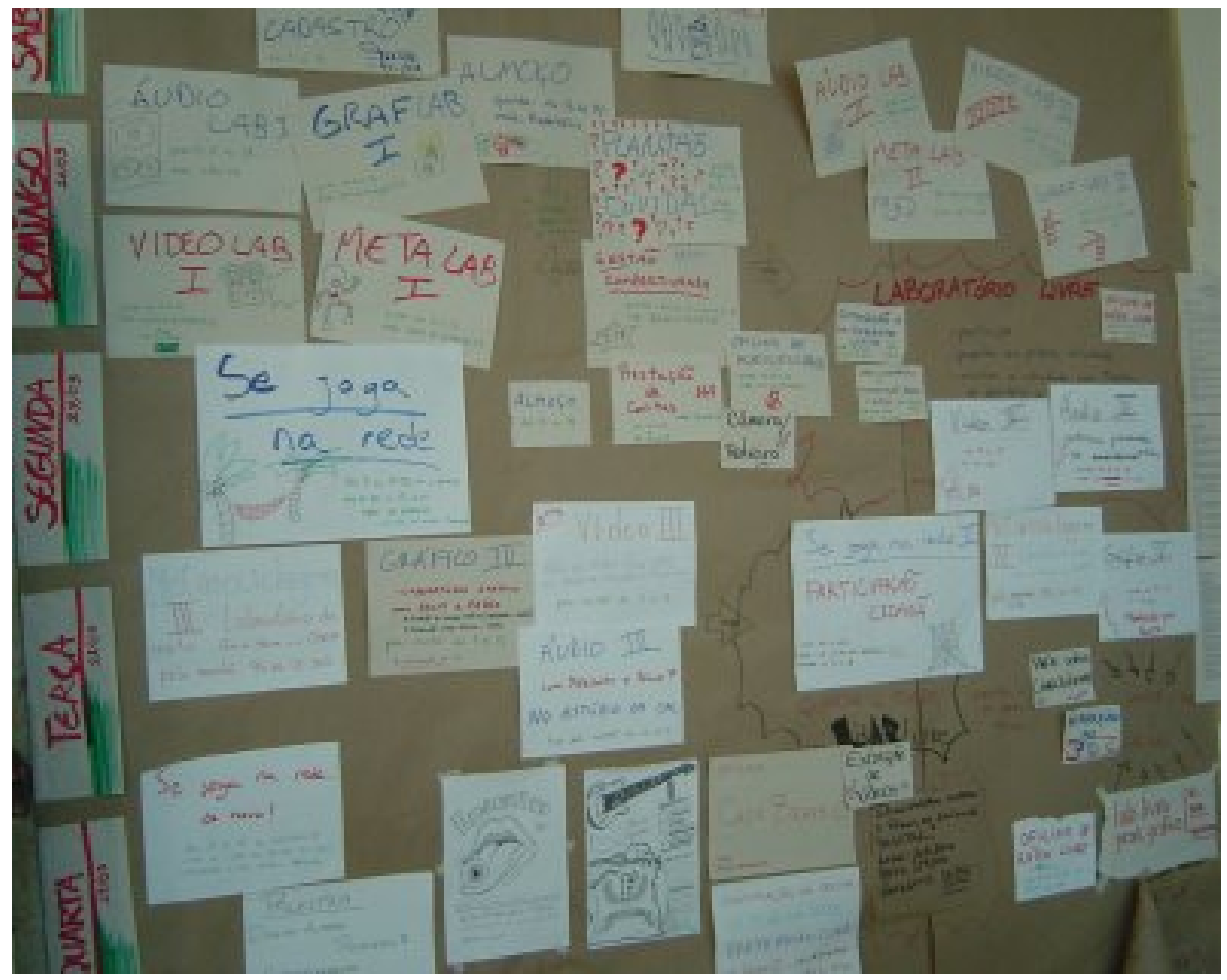

Figura 4.3: Um mural mostra o planejamento ágil de uma oficina de conhecimentos livres. Participantes podiam propor mudanças no cronograma e até mesmo novas atividades durante a oficina

áreas se encontram em frente do quadro de histórias para discutir as tarefas que devem realizar no dia. Observamos que esta prática é muito eficaz para melhorar a comunicação interna em equipes que colaboram no seu trabalho.

Finalmente, a prática de Retrospectivas e Retroperspectivas mostra-se valiosa independente da área na qual é aplicada. Tanto na Paggo quanto na Cultura Digital, retrospectivas são realizadas com freqüência para que equipes possam descobrir falhas e propor melhorias ao seu processo de trabalho. A Figura 4.4 mostra um cartaz de uma retroperspectiva realizada por todas as áreas da Cultura Digital em conjunto no final de 2006. 


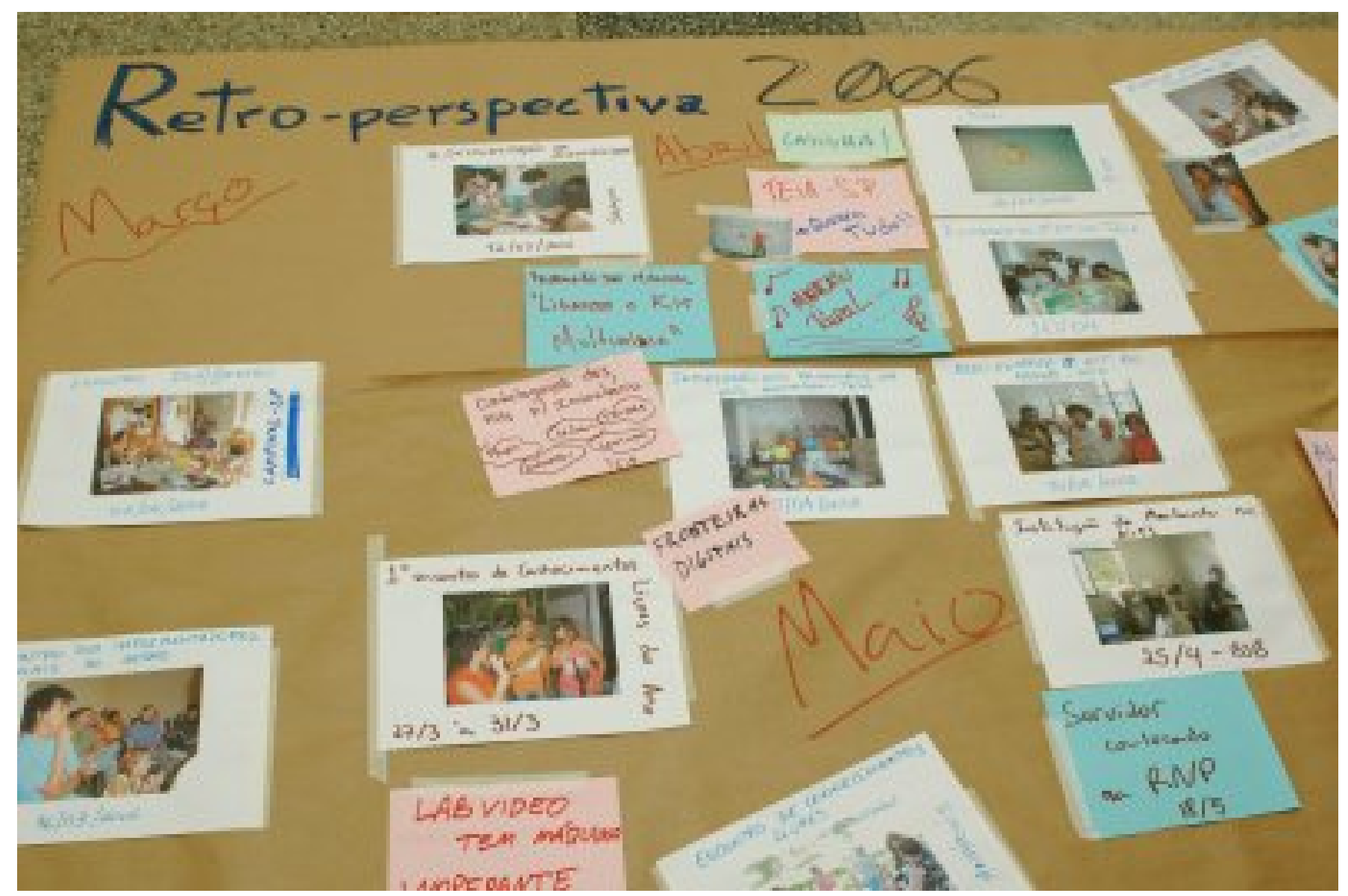

Figura 4.4: Retrospectivas são úteis para qualquer equipe que trabalha de maneira colaborativa visualizar o que foi feito em um projeto e sugerir ações concretas de melhoria 


\section{Capítulo 5}

\section{Conclusões}

Este trabalho estudou o ensino de XP como metodologia aplicada aos contextos acadêmicos, industriais e governamentais. Além da discussão sobre os conceitos e teorias relacionados ao ensino e aplicação de Programação eXtrema, três estudos de caso foram conduzidos. Analisamos estes casos e as evidências presentes na literatura, além de práticas de outras metodologias ágeis, para validar algumas linguagens de padrões e anti-padrões que podem ser usados para facilitar o ensino da metodologia nestes diferentes contextos.

Apresentamos um pouco da história e motivação por trás do surgimento das metodologias ágeis e refletimos sobre os valores, princípios e práticas propostos pela Programação eXtrema, observando a evolução pela qual passou ao longo dos últimos anos.

Mostramos que o ensino de XP não é uma tarefa trivial. Descrevemos diversas experiências de ensino e adoção da metodologia relatadas pela comunidade ágil e entramos em detalhes sobre nossas experiências no Laboratório de Programação eXtrema, na Paggo e na Cultura Digital.

Analisamos as experiências relatadas e refletimos sobre elas, sugerindo linguagens de padrões e anti-padrões que podem facilitar o trabalho de um educador. Alguns destes padrões apresentados são específicos para aplicação na academia, na indústria ou no governo.

Ensinar XP é de extrema importância para melhorar a qualidade do software produzido no Brasil. A tarefa é simples e rápida se comparada ao ensino de metodologias tradicionais. Sugerimos que algumas práticas sejam apresentadas por educadores o quanto antes no currículo acadêmico. Os padrões apresentados neste trabalho podem ser utilizados como ferramentas para auxiliar o educador que embarca nesta empreitada e melhorar o processo de ensino. As linguagens foram apresentadas na ordem em que devem ser aplicadas em uma experiência prática.

É possível ensinar métodos ágeis nestes contextos diferentes, proprocionando maior satisfação no trabalho para uma equipe e maior qualidade no software produzido por ela. Descobrimos maneiras de melhorar o ensino de práticas ágeis em todas as fases do aprendizado. 


\subsection{Principais contribuições}

Dentre as principais contribuições deste trabalho, destacam-se:

- O estudo detalhado de experiências de ensino na academia, indústria e no governo presentes na literatura.

- O estudo de três experiências práticas de ensino da metodologia.

- A sugestão de linguagens de padrões e anti-padrões que podem melhorar a experiência de ensino em diversos contextos

- A classificação destas linguagens entre aquelas que podem ser aplicados antes de começar uma experiência, durante o ensino e após uma equipe amadurecer sua prática metodológica.

- A sugestão de que as práticas de testes automatizados e programação pareada sejam apresentadas mais cedo no currículo acadêmico.

- A primeira experiência de uso de práticas ágeis em outras áreas que não a programação de software.

- A identificação dos padrões Mapas Mentais, Participe de Eventos, Conheça a Comunidade, Curso Rápido, Curso Médio, Primeiro Planejamento VIP, Meta-Treinador, Faça Duas Vezes, Use Clientes Reais, Comunidade de Usuários Ativa, Estagiário Acompanhador, Acompanhamento On-Line, Domine os Pré-Requisitos, Experiência Prévia, Espaço Virtual Informativo, Got Root?, Use Software Livre, Script de Build, Almoço eXtremo, Projeto Piloto, Use Arcabouços Livres, Diários de um Treinador, Apoiar o Cliente, Seja Paciente, Lista de Presença, Tempo Extra, Lista de Discussão, Tempo de Estudo, Use Projeto Real, Adote Projeto Continuado, Bug Fix Release, Reunião de Lavar Roupa Suja, Mantenha o Nível, Demita-o, Treinador da Semana, Retroperspectiva, Tradutor, Cobrador, Tech Day, Imersão eXtrema e Tracker Bot que não haviam sido documentados antes desta dissertação.

- A identificação dos anti-padrões Faça Você Mesmo, Personalidades Múltiplas, Carro na Frente dos Bois, Velhos Dinossauros, Sem as Bases, Passos Pequenos Demais, Resistência ao Meta-Treinador, Abandonar o Navio, Fofoca, Panelinha, Espaço Aberto Demais, Excesso de Hora Extra e Complexo de Abandono que não haviam sido documentados antes desta dissertação.

\subsection{Trabalhos futuros}

O presente estudo pode ser melhorado. Sugerimos os seguintes tópicos como questões que podem ser abordadas no futuro: 
- Sugerir mais padrões e tecnologias para melhorar o aprendizado da prática de testes automatizados, pois observamos que é esta a que apresenta mais problemas.

- Realizar mais experiências em contextos governamentais para explicitar melhor as diferenças entre este e o setor privado.

- Fazer um trabalho detalhado sobre o uso de práticas ágeis em grupos que não tem como objetivo final programar software.

\subsection{Artigos publicados durante o Mestrado}

Durante a pesquisa publicamos três artigos sobre sistemas desenvolvidos utilizando XP, o Mico [FGF+ 04], o VRaptor [FS04] e o Cigarra [FGK05]. Além destes nossa experiência na Paggo foi publicada em uma das principais conferências internacionais da área, a XP 2005 [FKT05]. O nosso trabalho com identificação de padrões também foi publicado em um workshop brasileiro, o WDRA 2007 [FKG07]. 


\section{Referências Bibliográficas}

[ABS03] Johan Andersson, Geoff Bache, and Peter Sutton. XP with Acceptance-Test Driven Development: A Rewrite Project for a Resource Optimization System. In Proceedings of the 4 th International Conference on eXtreme Programming and Agile Processes in Software Engineering (XP 2003), volume 2675 of Lecture Notes on Computer Science, pages $180-188,2003.8$

[ADW01] O. Astrachan, R. Duvall, and E. Wallingford. Bringing eXtreme Programming to the Classroom. In Proceedings of XP Universe 2001, Raleigh, NC, USA, 2001. 8, 46

[AHS03] GB Alleman, M. Henderson, and R. Seggelke. Making Agile Development Work in a Government Contracting Environment-Measuring Velocity with Earned Value. Agile Development Conference, 2003. ADC 2003. Proceedings of the, pages 114-119, 2003. 73

[AIS $\left.{ }^{+} 77\right]$ C. Alexander, S. Ishikawa, M. Silverstein, et al. A Pattern Language: Towns, Buildings, Construction. Oxford University Press, 1977. 10, 94

[All01] Agile Alliance. Manifesto for Agile Software Development. Home page: http: //agilemanifesto.org, 2001. 5

[Amb98] S.W. Ambler. Process Patterns-Buiding Large-Scale Systems Using OO Technology, 1998. 10,86

[Amb99] S.W. Ambler. More Process Patterns. SIGS Books New York, 1999. 10, 86

[Amb02] S. W. Ambler. Agile Modeling. John Wiley \& Sons, 2002. 106

[And01] J. Andrea. Managing the Bootstrap Story in an XP Project. In Proceedings of XP 2001, North Carolina,, 2001. 8, 99

[Ant04] Gary H. Anthes. Sabre Takes eXtreme Measures. Computer World, see www. computerworld.com/softwaretopics/software/story/0, 10801, 91646, 00.html, March 2004. 8, 45

[AS06] Scott W. Ambler and Pramod J. Sadalage. Refactoring Databases: Evolutionary Database Design. Addison-Wesley, 2006. 8, 25

[ASA79] Joichi Abe, Ken Sakamura, and Hideo Aiso. An Analysis of Software Project Failure. In ICSE '79: Proceedings of the 4th international conference on Software engineering, pages 378-385, Piscataway, NJ, USA, 1979. IEEE Press. 2 
[Asp04] G. Asproni. Motivation, Teamwork, and Agile Development. Agile Times, IV(1):8-15, 2004. 7

[Ave04] B. Aveling. XP Lite Considered Harmful? In Proceedings of the 5th international conference on eXtreme Programming and Agile Processes in Software Engineering (XP 2004), volume 3092 of Lecture Notes on Computer Science, pages 94-103. Springer, 2004. 8,45

[BA04] Kent Beck and Cynthia Andres. Extreme Programming Explained: Embrace Change, 2nd Edition. Addison-Wesley, 2 edition, 2004. 3, 6, 7, 9, 17, 35, 85, 86, 93, 94

[Bec99] Kent Beck. Extreme Programming Explained: Embrace Change. Addison-Wesley, 1 edition, 1999. 6, 7, 9, 20, 30, 53, 86, 100

[Bec02a] Kent Beck. Test-Driven Development: By Example. Addison-Wesley, 2002. 8, 24

[Bec02b] Kent Beck. The Metaphor Metaphor. Keynote speech - ACM OOPSLA'02, November 2002. 16

[Ben02] Yochai Benkler. Coase's Penguin, or, Linux and The Nature of the Firm. Yale Law Journal, 1(112):369-446, 2002. 4

[BG98] K. Beck and E. Gamma. Test Infected: Programmers Love Writing Tests. Java Report, 3(7):37-50, 1998. 8

[BK07] Paulo Cheque Bernardo and Fabio Kon. Desenvolvendo com Agilidade: Experiências na Reimplementação de um Sistema de Grande Porte. In Workshop de Desenvolvimento Rápido de Aplicações (WDRA 2007), 2007. 8

[BMMIM98] W.J. Brown, R.C. Malveau, H.W. McCormick III, and T.J. Mowbray. AntiPatterns: Refactoring Software, Architectures, and Projects in Crisis. John Wiley \& Sons, Inc. New York, NY, USA, 1998. 10

[Bos02] L. Bossavit. The Unbearable Lightness of Programming: A Tale of Two Cultures. CUTTER IT JOURNAL, 15(9):5-11, 2002. 8

[Bos03a] P. Bossi. Using Actual Time: Learning How to Estimate. In Proceedings of the 4th International Conference on eXtreme Programming and Agile Processes in Software Engineering (XP 2003), volume 2675 of Lecture Notes on Computer Science, pages 244-253, 2003. 8

[Bos03b] Piergiuliano Bossi. eXtreme Programming Applied: a Case In the Private Banking Domain. In Proceedings of OOP, Munich, 2003. Available at www.quinary.com/pagine/ downloads/files/Resources/00P2003Paper.pdf. 8, 45, 67

[BPBLS03] P. Becker-Pechau, H. Breitling, M. Lippert, and A. Schmolitzky. Teaching Team Work: An Extreme Week for First-Year Programmers. In Proceedings of 4th International Conference on Extreme Programming and Agile Processes in Software Engineering (XP 2003), volume 2675 of Lecture Notes on Computer Science, pages 386-393. Springer, 2003. 8,48 
[BT00] H.W. McCormick Brown, W.J. and S.W. Thomas. AntiPatterns in Project Management. John Wiley \& Sons, 2000. 10, 86

[CCH96] B.G. Cain, J.O. Coplien, and N.B. Harrison. Social Patterns in Productive Software Development Organizations. Annals of Software Engineering, 2(1):259-286, 1996. 10, 86

[CH04] J.O. Coplien and N.B. Harrison. Organizational Patterns of Agile Software Development. Prentice-Hall, Inc. Upper Saddle River, NJ, USA, 2004. 10, 86, 94, 95, 100

[Cho05] Jan Chong. Social Behaviors on XP and non-XP teams: A Comparative Study. In ADC '05: Proceedings of the Agile Development Conference, pages 39-48, Washington, DC, USA, 2005. IEEE Computer Society. 7

[CHW01] L. Crispin, T. House, and C. Wade. The Need for Speed: Automating Acceptance Testing in an Extreme Programming Environment. Second International Conference on eXtreme Programming and Flexible Processes in Software Engineering (XP 2001, pages $96-104,2001.8$

[CKS03] M.B. Chrissis, M. Konrad, and S. Shrum. Cmmi: Guidelines for Process Integration and Product Improvement. Addison-Wesley Professional, 2003. 73

[Coc02] Alistair Cockburn. Agile Software Development: The Cooperative Game. AddisonWesley Longman, 2002. 7, 10, 17, 34, 51, 101

[Coc04] Alistair Cockburn. Crystal Clear: A Human-Powered Methodology for Small Teams. Addison-Wesley Professional, 2004. 7

[Cro02] Mark Crowne. Why Software Product Startups Fail and What To Do About It. In Proceedings of 2002 IEEE International Engineering Management Conference (IEMC 2002), pages 338-343, 2002. 2

[Cro04] Ron Crocker. Large-Scale Agile Software Development. Addison-Wesley, 2004. 42

[CS05] Robert Cowham and Matt Stephens. To XP or not to XP? The Computer Bulletin, 47(2):16-16, March 2005. 8

[CW00] A. Cockburn and L. Williams. The Costs and Benefits of Pair Programming. In Proceedings of the First International Conference on Extreme Programming and Flexible Processes in Software Engineering (XP2000), Cagliari, Sardinia, Italy, June 2000. 8, 25

[dCFPSB05] E.G. da Costa Filho, R. Penteado, J.C.A. Silva, and R.T.V. Braga. Padrões e Métodos Ágeis: Agilidade no Processo de Desenvolvimento de Software. In Proceedings of the 5th Latin American Conference on pattern Languages of Programming, pages 156-169, 2005. 10,86

[dH95] Sérgio Buarque de Holanda. Raízes do Brasil. Companhia das Letras, 1995. 85

[DH04] Yael Dubinsky and Orit Hazzan. Roles in Agile Software Development Teams. In Proceedings of the 5th International Conference on eXtreme Programming and Agile Processes in Software Engineering (XP 2004), volume 3092 of Lecture Notes on Computer Science, pages 157-165, 2004. 8, 49, 95 
[dLP $\quad$ Dicionário Houaiss da Língua Portuguesa. Metodologia. verbete. 9

[dLPA] Novo Dicionário Básico da Língua Portuguesa Aurélio. Metodologia. verbete. 9

[dM00] Domenico de Masi. O Ócio Criativo. Sextante, Rio de Janeiro, 2000. 3

[DMM02] Roberto Deias, Giampiero Mugheddu, and Orlando Murru. Introducing XP In a StartUp. In Proceedings of the 3rd International Conference on Extreme Programming and Agile Processes in Software Engineering (XP2002), 2002. 8, 45, 64

[Dub03] Y. Dubinsky. Teaching eXtreme Programming in a Project-Based Capstone Course. In Proceedings of 4 th International Conference on Extreme Programming and Agile Processes in Software Engineering (XP 2003), volume 2675, pages 435-436. Springer, 2003. 8, 49

[DW03] Joel Aufgang Doug Wallace, Isobel Raggett. Extreme Programming for Web Projects. Addison-Wesley, 2003. 7

[EK06] Nicholas Epley and Justin Kruger. Egocentrism Over E-Mail: Can We Communicate as Well as We Think? Journal of Personality and Social Psychology, 89(5):925-936, 2006. 16

[FG02] Ernst Fehr and Simon Gächter. Do Incentive Contracts Crowd Out Voluntary Cooperation? Institute for Empirical Research in Economics, University of Zurich, Working Paper No. 34 http://www.iew.unizh.ch/wp/iewwp034.pdf, 2002. 4

$\left[\mathrm{FGF}^{+}\right.$04] Alexandre Freire, Alfredo Goldman, Carlos Eduardo Ferreira, Christian Asmussen, and Fabio Kon. Mico - University Schedule Planner. In Anais do 5o Workshop sobre Software Livre (WSL 2004), pages 147-150, Porto Alegre, Junho 2004. 7, 49, 59, 119

[FGK05] Alexandre Freire, Francisco Gatto, and Fabio Kon. Cigarra-A Peer-to-Peer Cultural Grid. In Anais do 6o Workshop sobre Software Livre (WSL 2005), pages 177-183, 2005. $7,49,50,61,119$

[FH03] Andrew M. Fuqua and John M. Hammer. Embracing Change: An XP Experience Report. In Proceedings of the 4th International Conference on eXtreme Programming and Agile Processes in Software Engineering (XP 2003), volume 2675 of Lecture Notes on Computer Science, pages 298-306, 2003. 8, 45, 66

[FJ01] Bruno S. Frey and Reto Jegen. Motivation Crowding Theory: A Survey of Empirical Evidence. Journal of Economic Surveys, 15:589-611, 2001. 4

[FKG07] Alexandre Freire, Fabio Kon, and Alfredo Goldman. The "Bootstrap", "Split Personality" and "Abandon Complex" Antipractices - eXPeriences Teaching XP in Academic and Business Environments. In Workshop de Desenvolvimento Rápido de Aplicações (WDRA 2007), 2007. 10, 86, 93, 99, 110, 119

[FKT05] Alexandre Freire, Fábio Kon, and Cícero Torteli. XP South of the Equator: An eXPerience Implementing XP in Brazil. In Proceedings of the XP 2005 Conference, volume 3556 of Lecture Notes on Computer Science, pages 10-18. Springer, 2005. 8, 67, 104, 105, 111, 119 
[FL04] Ernst Fehr and John A. List. The Hidden Costs and Returns of Incentives - Trust and Trustworthiness among Ceos. Journal of the European Economic Association, $2(5): 743-771,2004.4$

[FNKW02] C. Farell, R. Narang, S. Kapitan, and H. Webber. Towards an Effective Onsite Customer Practice. In Proceedings of the 3rd International Conference on Extreme Programming and Agile Processes in Software Engineering (XP2002), pages 52-55, 2002. 8

[FOG97] Bruno S. Frey and Felix Oberholzer-Gee. The Cost of Price Incentives: An Empirical Analysis of Motivation Crowding Out. American Economic Review, 87:746-755, 1997. 4

[Fow99] Martin Fowler. Refactoring: Improving the Design of Existing Code. Addison-Wesley, 1999. $8,24,25$

[Fow00] Martin Fowler. Is Design Dead? In Proceedings of the Extreme Programming Conference 2000 Caligary, Italy (XP2000), 2000. Revised 2004 version available at http://www.martinfowler.com/articles/designDead.html. 4

[Fow01] Martin Fowler. Yesterday's Weather. available at: http://www.martinfowler.com/ bliki/YesterdaysWeather.html, 2001. 20

[FS04] Alexandre Freire and Paulo Silveira. VRaptor - Simple and Quick Web Framework. In Anais do 5o Workshop sobre Software Livre (WSL 2004), pages 39-42, 2004. 7, 119

[FY00] B. Foote and J. Yoder. Big Ball of Mud. Pattern Languages of Program Design, 4:654-692, 2000. 99

[GHJV95] Erich Gamma, Richard Helm, Ralph Johnson, and John Vlissides. Design Patterns. Addison-Wesley, Reading, MA, 1995. 10, 25

[GKSY04] Alfredo Goldman, Fabio Kon, Paulo J. S. Silva, and Joseph W. Yoder. Being Extreme in the Classroom: Experiences Teaching XP. Journal of the Brazilian Computer Society, 10(2):1-17, November 2004. 6, 8, 49, 73

[Gri01] L. Griffin. A Customer Experience: Implementing XP. In Proceedings of the XP Agile Universe Conference, 2001. 8

[GW04] B. George and L. Williams. A Structured Experiment of Test-Driven Development. Information and Software Technology, 46(5):337-342, 2004. 8, 24

[HA05] Hanna Hulkko and Pekka Abrahamsson. A Multiple Case Study on the Impact of Pair Programming on Product Quality. In ICSE '05: Proceedings of the 27th international conference on Software engineering, pages 495-504. ACM Press, 2005. 8, 18

$\left[\mathrm{HBC}^{+} 04\right] \quad$ Orit Hazzan, Joe Bergin, James Caristi, Yael Dubinsky, and Laurie Williams. Teaching Software Development Methods: The Case of eXtreme Programming. In Panel at the 35th Technical Symposium on Computer Science Education (SIGCSE'2004), Norfolk, Virginia, USA, 2004. ACM. 8, 46

[HBM03a] G. Hedin, L. Bendix, and B. Magnusson. Coaching Coaches. In Proceedings of 4th International Conference on Extreme Programming and Agile Processes in Software Engineering (XP 2003), volume 2675, pages 154-160. Springer, 2003. 8, 48 
[HBM03b] G. Hedin, L. Bendix, and B. Magnusson. Introducing Software Engineering by Means of eXtreme Programming. In Proceedings of the 25th International Conference on Software Engineering, pages 586-593, 2003. 8, 48

[HBM05] G. Hedin, L. Bendix, and B. Magnusson. Teaching eXtreme Programming to Large Groups of Students. The Journal of Systems \& Software, 74(2):133-146, 2005. 8, 48

[HD03] O. Hazzan and Y. Dubinsky. Teaching a Software Development Methodology: The Case of eXtreme Programming. In Proceedings of the 16th Conference on Software Engineering Education and Training (CSEEET 2003), pages 176-184, 2003. 8, 49

[HGM01] M. Holcombe, M. Gheorghe, and F. Macias. Teaching XP for real: Some Initial Observations and Plans. In Proceedings XP 2001, pages 14-17, 2001. 8, 47

[How03] Donald Howard. Swimming Around the Waterfall: Introducing and Using Agile Development in a Data Centric, Traditional Software Engineering Company. In Proceedings of the 4 th International Conference on eXtreme Programming and Agile Processes in Software Engineering (XP 2003), volume 2675 of Lecture Note in Computer Science, pages $138-145,2003.8,45,65$

[HT00] Andrew Hunt and David Thomas. The Pragmatic Programmer. Addison-Wesley, 2000. 7

[III99] J.A. Highsmith III. Adaptive Software Development: A Collaborative Approach To Managing Complex Systems. Dorset House Publishing, New York, 1999. 7

[Jac04] et al. Jackson, A. Behind the Rules: XP Experiences. In Proceedings of the 2004 Agile Development Conference, Salt Lake City, 2004. 8, 45, 110

[Jef04] Ron Jeffries. Big Visible Charts. available at http://www.xprogramming.com/xpmag/ BigVisibleCharts.htm, 2004. 32

[JST01] K. Johansen, R. Stauffer, and D. Turner. Learning by Doing: Why XP Doesn't Sell. In Proceedings of the XP Agile Universe 2001 Conference. Addison Wesley Longman, 2001. 8,45

[KA02] Roy Miller Ken Auer. Extreme Programming Applied: Playing to Win. Addison-Wesley, 2002. 7

[KA04] J. Koskela and P. Abrahamsson. On-Site Customer in an XP Project: Empirical Results from a Case Study. In at European Software Process Improvement Conference (EuroSPI 2004), Trondheim, Norway, volume 3281 of Lecture Note in Computer Science, pages 1-11. Springer, 2004. 8

[KB01] Martin Fowler Kent Beck. Planning Extreme Programming. Addison-Wesley, 2001. 7, 19

[Kee02] G. Keefer. Extreme Programming Considered Harmful for Reliable Software Development. AVOCA [Advanced Visioning of Components and Architectures] Technical Report, 2002. 8

[Ker05] Joshua Kerievsky. Refactoring to Patterns. Addison-Wesley, 2005. 25 
[KH04] Y. Kuranuki and K. Hiranabe. AntiPractices: AntiPatterns for XP Practices. In Proceedings of the 2004 Agile Development Conference, Salt Lake City, 2004. 10, 86, 101, 106, 107, 108

[Kre02] W. Krebs. Turning the Knobs: A Coaching Pattern for XP Through Agile Metrics. In Extreme Programming/Agile Universe, Chicago, IL, pages 60-69. Springer, 2002. 100

[Kru03] P. Kruchten. The Rational Unified Process: An Introduction. Addison-Wesley Professional, 2003. 64

[KVRR03] S. Kuppuswami, K. Vivekanandan, Prakash Ramaswamy, and Paul Rodrigues. The Effects of Individual XP Practices on Software Development Effort. SIGSOFT Softw. Eng. Notes, 28(6):6-6, 2003. 7

[Lap02] P. Lappo. No Pain, No XP: Observations on Teaching and Mentoring eXtreme Programming to University Students. In Procedings of the 3rd International Conference on eXtreme Programming and Agile Processes in Software Engineering (XP2002), Cagliari, Italy, 2002. 8, 46

[Lay04] Lucas Layman. Empirical Investigation of the Impact of eXtreme Programming Practices on Software Projects. In OOPSLA '04: Companion to the 19th annual ACM SIGPLAN conference on Object-oriented programming systems, languages, and applications, pages 328-329, New York, NY, USA, 2004. ACM Press. 7

[LC03a] Tip House Lisa Crispin. Testing Extreme Programming. Addison-Wesley, 2003. 7

[LC03b] K.M. Lui and K.C.C. Chan. When Does a Pair Outperform Two Individuals? In Proceedings of the 4th International Conference on eXtreme Programming and Agile Processes in Software Engineering (XP 2003), volume 2675 of Lecture Note in Computer Science. Springer, 2003. 8, 18, 25

[LC04] Kim Man Lui and Keith C.C. Chan. Test Driven Development and Software Process Improvement in China. In Proceedings of the 5th International Conference on eXtreme Programming and Agile Processes in Software Engineering (XP 2004), volume 3092 of Lecture Notes on Computer Science, pages 219-222, 2004. 8, 24

[LC06] Kim M. Lui and Keith C. C. Chan. Pair programming productivity: Novice-Novice vs. eXpert-eXpert. Int. J. Hum.-Comput. Stud., 64(9):915-925, September 2006. 8

[Lit00] Jim Little. Ats Diary. C2 wiki site, 2000. see htt[://c2.com/cgi/wiki?AtsDiary. 8,45

[LWC04a] L. Layman, L. Williams, and L. Cunningham. Exploring eXtreme Programming In Context: An Industrial Case Study. Agile Development Conference, 2004, pages 3241, 2004. 8, 45, 66

[LWC04b] Lucas Layman, Laurie Williams, and Lynn Cunningham. Motivations and Measurements in an Agile Case Study. In QUTE-SWAP '04: Proceedings of the 2004 workshop on Quantitative techniques for software agile process, pages 14-24, New York, NY, USA, 2004. ACM Press. 7 
[Mar04] Angela Martin. Exploring the XP Customer Role : Part II. In Proceedings of the 5th international conference on eXtreme Programming and Agile Processes in Software Engineering (XP 2004), volume 3092 of Lecture Notes on Computer Science, page 318. Springer, 2004. 8

[Mar07] Angela Michelle Martin. The Role of Customers on Extreme Programming Projects. PhD thesis, Victoria University of Wellington, Department of Philosophy, 2007. 8

[McB03] P. McBreen. Questioning Extreme Programming. Addison Wesley, 2003. 8

[Mem01] Atif M. Memon. A Comprehensive Framework for Testing Graphical User Interfaces. $\mathrm{PhD}$ thesis, University of Pittsburgh, July 2001. 8

[Mem02] Atif M. Memon. GUI Testing: Pitfalls and Process. IEEE Computer, 35(8):90-91, August 2002. 8

[Mes04] J. Meszaros. Using Storyotypes to Split Bloated XP Stories. In Proceedings of the XP/Agile Universe 2004, volume 3134, pages 73-80, North Carolina,, 2004. Springer. 8,99

$\left[\mathrm{MFR}^{+}\right.$04] D. McKinney, J. Froeseth, J. Robertson, L.F. Denton, and D. Ensminger. Agile CS1 Labs: eXtreme Programming Practices in an Introductory Programming Course. Proceedings of XP/Agile Universe 2004, Calgary, Canada, August 15-18, 2004. Lecture Notes in Computer Science, 2004. 8, 48

[Mis06] Vojislav B. Misić. Perceptions of eXtreme Programming: An Exploratory Study. SIGSOFT Softw. Eng. Notes, 31(2):1-8, March 2006. 7

[MLSM04] M. Müller, J. Link, R. Sand, and G. Malpohl. Extreme Programming in Curriculum: Experiences from Academia and Industry. In Proceedings of the 5th International Conference on eXtreme Programming and Agile Processes in Software Engineering (XP 2004), volume 3092 of LNCS, pages 294-302. Springer, June 2004. 8, 48

[MM06] Grigori Melnik and Frank Maurer. Comparative Analysis of Job Satisfaction in Agile and Non-agile Software Development Teams. In Proceedings of Extreme Programming and Agile Processes in Software Engineering, 7th International Conference, XP 2006, Oulu, Finland, June 17-22, 2006, volume 4044 of Lecture Notes in Computer Science, pages $32-42$. Springer, 2006. 7

[MMM04] K. Mannaro, M. Melis, and M. Marchesi. Empirical Analysis on the Satisfaction of IT Employees Comparing XP Practices with Other Software Development Methodologies. In Proceedings of the 5th international conference on eXtreme Programming and Agile Processes in Software Engineering (XP 2004), volume 3092 of Lecture Notes on Computer Science, pages 166-174. Springer, 2004. 7

[MMRT03] R. Mugridge, B. MacDonald, P. Roop, and E. Tempero. Five Challenges in Teaching XP. In Proceedings of 4 th International Conference on Extreme Programming and Agile Processes in Software Engineering (XP 2003), volume 2675, pages 406-409. Springer, 2003. 8,48

[MN04] R. Biddle Martin, A. and J. Noble. The XP Customer Role in Practice: Three Studies. In Proceedings of the 2004 Agile Development Conference, Salt Lake City, 2004. 8 
[MNB03] A. Martin, J. Noble, and R. Biddle. Being Jane Malkovich: A Look Into the World of an XP Customer. In Proceedings of the 4 thInternational Conference on eXtreme Programming and Agile Processes in Software Engineering (XP2003), volume 2675 of Lecture Note in Computer Science, pages 234-243. Springer, 2003. 8

[Mon98] Yasuhiro Monden. Toyota Production System: An Integrated Approach to Just-in-Time. Engineering \& Management Press, Norcross, GA, 3 edition, 1998. 4

[MP03] M.M. Muller and F. Padberg. About the Return on Investment of Test-Driven Development. International Workshop on Economics-Driven Software Engineering Research EDSER, 5, 2003. 8

[MS99] K. Maruyama and K. Shima. Automatic Method Refactoring Using Weighted Dependence Graphs. In Proceedings of the 21st international conference on Software engineering, pages 236-245. IEEE Computer Society Press, 1999. 8

[MT01] M. Müller and W. Tichy. Case Study: eXtreme Programming in a University Environment. In Proceedings of the 23rd International Conference on Software Engineering, 2001. ICSE 2001, pages 537-544, 2001. 8, 48

[Mug03] R. Mugridge. Challenges in Teaching Test Driven Development. In Proceedings of the 4 th International Conference on eXtreme Programming and Agile Processes in Software Engineering (XP 2003), volume 2675 of Lecture Notes on Computer Science, pages 410413, 2003. 8

[Mü104] Roger A. Müller. Extreme Programming in a University Project. In Proceedings of the 5th International Conference on eXtreme Programming and Agile Processes in Software Engineering (XP 2004), volume 3092 of Lecture Notes on Computer Science, pages 312$315,2004.8,49$

[NA03] John Noll and Darren C Atkinson. Comparing eXtreme Programming to Traditional Development for Student Projects: A Case Study. In Proceedings of the 4th International Conference on Extreme Programming and Agile Processes in Software Engineering, XP 2003, Lecture Notes in Computer Science, pages 372-374. Springer-Verlag, 2003. 8,47

[NH04] M.F. Nisar and T. Hameed. Agile Methods Handling Offshore Software Development Issues. In Proceedings of the 8th International Multitopic Conference (INMIC 2004), pages $417-422,2004$. 34

[NMMB04] J. Noble, S. Marshall, S. Marshall, and R. Biddle. Less Extreme Programming. Proceedings of the sixth conference on Australian computing education, 30:217-226, 2004. 8,47

$\left[\mathrm{NWW}^{+} 03\right] \quad$ N. Nagappan, L. Williams, E. Wiebe, C. Miller, S. Balik, M. Ferzli, and M. Petlick. Pair Learning: With an Eye Toward Future Success. In Extreme Programming and Agile Methods - XP/Agile Universe 2003, volume 2753 / 2003 of Lecture Notes in Computer Science, pages 185 - 198. Springer-Verlag Heidelberg, September 2003. 8

[PE85] D. E. Perry and W. M. Evangelist. An Empirical Study of Software Interface Faults. In Proceedings of the International Symposium on New Directions in Computing, pages 32-38, August 1985. 2 
[Pel00] Joseph Pelrine. Modelling Infection Scenarios - A Fixed-Price eXtreme Programming Success Story. In ACM OOPSLA Companion Proceedings, pages 23-24. ACM Press, 2000. $8,45,64$

[PF02] Steven R. Palmer and John M. Felsing. A Practical Guide to Feature-Driven Development. Prentice Hall, 2002. 7

[PP03] M. Poppendieck and T. Poppendieck. Lean Software Development: An Agile Toolkit for Software Development Managers. Addison-Wesley, 2003. 7

[PWCC95] M.C. Paulk, C.V. Weber, B. Curtis, and M.B. Chrissis. The Capability Maturity Model: Guidelines for Improving the Software Process. Addison-Wesley Longman Publishing Co., Inc. Boston, MA, USA, 1995. 73

[RD03] L. Rising and E. Derby. Singing the Songs of Project Experience: Patterns and Retrospectives. Journal of Information Technology, 16(9), 2003. 34

[Rei02] D. J. Reifer. How to Get the Most out of Extreme Programming/Agile Methods. In Proceedings of the 2nd XP and 1st Agile Universe Conference, volume 2418 of Lecture Notes on Computer Science, pages 185-196, Chicago, IL, August 2002. Springer. 7

[RJ01] Chet Hendrickson Ron Jeffries, Ann Anderson. Extreme Programming Installed. Addison-Wesley, 2001. 7

[RM05] Linda Rising and Mary Lynn Manns. Fearless Change. Patterns for Introducing New Ideas. Addison-Wesley, Boston, 2005. 10, 85, 86, 88

[Rog04] R.O. Rogers. Scaling Continuous Integration. In Proceedings of the 5th international conference on eXtreme Programming and Agile Processes in Software Engineering (XP 2004), volume 3092 of Lecture Notes on Computer Science, pages 68-76. Springer, 2004. 8

[RS02] B. Rumpe and A. Schröder. Quantitative Survey on Extreme Programming Projects. In Proceedings of the 3rd International Conference on Extreme Programming and Flexible Processes in Software Engineering (XP2002), pages 95-100, Alghero, Italy, 2002. 7

[SA04] Outi Salo and Pekka Abrahamsson. Empirical Evaluation of Agile Software Development: The Controlled Case Study Approach. In Proceedings of the 5th International Product Focused Software Process Improvement Conference (PROFES 2004), volume 3009 of Lecture Notes in Computer Science, pages 408-423. Springer Berlin / Heidelberg, 2004. 7

[SAHG03] S. Syed-Abdullah, M. Holcombe, and M. Gheorghe. Practice Makes Perfect. In Proceedings of 4th International Conference on Extreme Programming and Agile Processes in Software Engineering (XP 2003), volume 2675, pages 354-356. Springer, 2003. 8, 47

[Sat07] Danilo Toshiaki Sato. Uso Eficaz de Métricas em Métodos Ágeis de Desenvolvimento de Software. Master's thesis, Universidade de São Paulo, Departmento de Ciência da Computação, 2007. 8, 102, 105

[SB01] Ken Schwaber and Mike Beedle. Agile Software Development with Scrum. Prentice Hall, 2001. 7, 33, 104 
$\left[\mathrm{SBB}^{+}\right.$07] Danilo Sato, Dairton Bassi, Mariana Bravo, Alfredo Goldman, and Fabio Kon. Experiences Tracking Agile Projects: an Empirical Study. Journal of the Brazilian Computer Society, 2007. http://www.dtsato.com/resources/default/jbcs-ese-2007.pdf. 7

[SBG07] Danilo Sato, Dairton Bassi, and Alfredo Goldman. Extending Extreme Programming With Practices From Other Agile Methodologies. In Workshop de Desenvolvimento Rápido de Aplicações (WDRA 2007), 2007. 33, 34, 104

[SCU97] R. SCUPIN. The KJ Method: A Technique for Analyzing Data Derived from Japanese Ethnology. Human organization, 56(2):233-237, 1997. 34

[SGK07] Danilo Sato, Alfredo Goldman, and Fabio Kon. Tracking the Evolution of ObjectOriented Quality Metrics on Agile Projects. In To be published in: 8th International Conference on Extreme Programming and Agile Processes in Software Engineering (XP 2007), 2007. http://www.dtsato.com/resources/default/xp-2007.pdf. 7

[SIC01] P. Schuh, T.W. Inc, and IL Chicago. Recovery, Redemption, and eXtreme Programming. Software, IEEE, 18(6):34-41, 2001. 8, 45

[SJ03] J.G. Schneider and L. Johnston. eXtreme Programming at Universities-An Educational Perspective. International Conference on Software Engineering, Portland, Oregon, USA, pages 594-599, 2003. 8, 47

[SJ05] J.G. Schneider and L. Johnston. eXtreme Programming - Helpful or Harmful In Educating Undergraduates? The Journal of Systems \& Software, 74(2):121-132, 2005. 8,47

$\left[\mathrm{SKKL}^{+} 04\right]$ O. Salo, andP. Kyllönem K. Kolehmainem, J. Löthman, S. Salmijärvi, and P. Abrahamsson. Self-Adaptability of Agile Software Processes: A Case on Postiteration Workshops. In Proceedings of the 5th international conference on eXtreme Programming and Agile Processes in Software Engineering (XP 2004), volume 3092 of Lecture Notes in Computer Science, pages 184-193. Springer, 2004. 34

$\left[\mathrm{SPA}^{+} 06\right]$ Sfetsos, Panagiotis, Angelis, Lefteris, Stamelos, and Ioannis. Investigating the eXtreme Programming System: An Empirical Study. Empirical Software Engineering, 11(2):269-301, June 2006. 7

[SR03] M. Stephens and D. Rosenberg. Extreme Programming Refactored: The Case Against XP. Apress, 2003. 8

[SSP01] G. Succi, M. Stefanovic, and W. Pedrycz. Quantitative Assessment of eXtreme Programming Practices. In Canadian Conference on Electrical and Computer Engineering, 2001, volume 1, pages 81-86 vol.1, 2001. 7

[Sta97] J. Stapleton. Dynamic Systems Development Method: The Method in Practice. Addison-Wesley, 1997. 7

[Sta03] Standish Group International, Inc. CHAOS Report. http://www.standishgroup. com/press/article.php?id=2, 2003. 1 
[SW02] A. Shukla and L. Williams. Adapting eXtreme Programming for a Core Software Engineering Course. In Proceedings of the15th Conference on Software Engineering Education and Training (CSEEET 2002), pages 184-191, 2002. 8, 47

[Tay47] Frederick Winslow Taylor. Scientific Management. Harper and Row, 1947. 3

[Tel04] Vinícius Manhães Teles. Extreme Programming - Aprenda como Encantar seus Usuários Desenvolvendo Software com Agilidade e Alta Qualidade. Novatec, São Paulo, 2004. 7, 86

[Tel05] Vinícius Manhães Teles. Um Estudo de Caso da Adoção das Práticas e Valores do eXtreme Programming. Master's thesis, Universidade Federal do Rio de Janeiro, Departmento de Ciência da Computação, 2005. 8, 63, 92

[Tes03] B. Tessem. Experiences in Learning XP Practices: A Qualitative Study. In Extreme Programming and Agile Processes in Software Engineering, 4th International Conference, Genova, Italy, 2003. Springer. 7

[Tof01] Alvin Toffler. A Terceira Onda: a Morte do Industrialismo e o Nascimento de Uma Nova Civilização. Record, Rio de Janeiro, 26 edition, 2001. 2

[Tom02a] James E. Tomayko. A Comparison of Pair Programming to Inspections for Software Defect Reduction. Computer Science Education, 12(3):213-222, 2002. 8, 18

[Tom02b] I. Tomek. What I Learned Teaching XP. In Proceedings of the ACM OOPSLA Educators Symposium, pages 39-46, Seattle, Washington, USA, November 2002. 8, 48

[Ver06] VersionOne. The State of Agile Development. Available at http://www.versionone. net/surveyresults.asp, 2006. 7

[vG91] M. van Genuchten. Why is Software Late? An Empirical Study of Reasons For Delay in Software Development. IEEE Transactions in Software Engineering, 17(6), June 1991. 2

[Vin07] Vinícius Manhães Teles. Modelo de Contrato de Escopo Negociável. http://www.improveit.com.br/blog/articles/2007/03/23/ modelo-contrato-escopo-negociavel, 2007. acessado em 26/04/2007. 41

[Wak02] William C. Wake. Extreme Programming Explored. Addison-Wesley, 2002. 7, 20

[WBA02] N. Wallace, P. Bailey, and N. Ashworth. Managing XP with Multiple or Remote Customers. In Proceedings of the 3rd International Conference on Extreme Programming and Agile Processes in Software Engineering (XP2002), 2002. 8, 34

[Wil00] L. A. Williams. The Collaborative Software Process. PhD thesis, University of Utah, Department of Computer Science, 2000. 8

[Wil01] D. Wilson. Teaching XP: a Case Study. In Proceedings of XP Universe 2001, Raleigh, NC, USA, 2001. 8, 46

[WK00] L. A. Williams and R. R. Kessler. All I Really Need to Know About Pair Programming I Learned In Kindergarten. Communications of the ACM, 43(5):108-114, May 2000. 8 
[WK02] L. Williams and R. Kessler. Pair Programming Illuminated. Addison-Wesley, 2002. 8

[WK03] W. Wood and W. Kleb. Exploring XP for Scientific Research. IEEE Software, 20:30-36, 2003. 73

[WKCJ00] L. A. Williams, R. R. Kessler, W. Cunningham, and R. Jeffries. Strengthening the Case for Pair Programming. IEEE Software, 17(4):19-25, /2000. 8

[WKLA04] L. Williams, W. Krebs, L. Layman, and A. Antón. Toward a Framework for Evaluating Extreme Programming. In Proceedings of the Eighth International Conference on Empirical Assessment in Software Engineering (EASE 04), pages 11-20, 2004. 7

[Wue02] Klaus Wuestefeld. Customer Proxy and Libero. E-mail personal communication, September 2002. 34

$\left[\mathrm{WWY}^{+} 02\right]$ L. Williams, E. Wiebe, K. Yang, M. Ferzli, and C. Miller. In Support of Pair Programming in the Introductory Computer Science Course. Computer Science Education, 12(3):197-212, September 2002. 8 


\section{Índice Remissivo}

Abandonar o Navio, 105

Aceitação de Responsabilidade, 37

Acompanhador, 31, 91, 95

Acompanhamento On-Line, 95

Adaptive Software Development, 5

Adote Projeto Continuado, 98

AgilCoop, 84, 90, 93, 99

AgilPizza, 82, 93

Algoritmo Genético, 58

Alistair Cockburn, 10, 51

Almoço eXtremo, 52, 98, 102

Almoço VIP, 91

Alvin Toffler, 2

Análise da Causa Inicial, 40, 109

Anti-Padrões, 10

Apoiar o Cliente, 103

Arcabouços Livres, 99

Archimedes, 50, 99

Auto-semelhança, 36

Azureus, 61

Backlog, 104, 113

Benefício Mútuo, 36

BitTorrent, 61

Blog, 112

Borboleta, 50, 56, 99

Bug Fix Release, 105

Build Veloz, 39, 108

$\mathrm{C}++, 58,65$

Código Compartilhado, 26, 91, 97, 106

Código e Testes, 40, 60, 109

Calendário Niko-Niki, veja Humorômetro

Call Center, 111

Carro na Frente dos Bois, 65, 95

CEC, veja Centro de Ensino de Computação

Centro de Ensino de Computação, 82

CHAOS Report, 1
Ciclo de Estação, 39, 98, 103

Ciclo Semanal, 39, 103

Cigarra, 50, 60, 93, 94, 101, 103

Cliente, 114

Cliente Proxy, 34, 42, 56, 60, 67, 77, 78, 93, 111

Cliente Proxy, 75

Cliente Sempre Presente, veja Envolvimento Real com o Cliente

Clima de Ontem, 20, 104

CMMi, 73

Cobrador, 111

Coding Dojo, 84, 102

Colméia, 50, 60, 99

Combinados da Equipe, 97

Complexo de Abandono, 60, 110

Comunicação, 16

Comunidade de Usuários Ativa, 93

Conheça a Comunidade, 83, 89

Continuidade da Equipe, 40, 111

Contrate Especialistas, 95

Contrato de Escopo Negociável, 41, 63, 67, 91, 93

Conversê, 74,77

Coragem, 18

CruiseControl, 108

Crystal, 5, 7

Cultura Digital, 74, 80, 93, 96, 97, 99, 100, 102, 104-106, 108, 109, 111-114

Cultura Hacker, 80

Curso Médio, 46-48, 82, 90, 95

Curso Rápido, 48, 82, 90

CVS, 51

Defensor da Corte, 48, 60, 110

Deixe Eles Brincarem, 89

Demita-o, 71, 110

Desenvolvedores Controlam o Processo, 100

Desenvolvimento Dirigido por Testes, 109

Design Incremental, 39, 106 
Design simples, 23

Diários de um Treinador, 102

Diagramas de Gantt, 65

Diversidade, 37

Domenico de Masi, 3

Domine os Pré-Requisitos, 48, 70, 95

Dono da Bola, 106

Drupal, 76, 99

DSDM, veja Dynamic System Development Method Grupo de Estudos, 89

Dynamic System Development Method, 5, 7

e-Forum, 89

Eclipse, 33, 51, 61, 97

Economia, 36

Em Fases, 111

Engenharia de Software, 1, 2, 46, 48, 86, 88

Ensino

diferentes modalidades, 45,82

etapas do processo, 85

práticas de XP no currículo, 46, 48, 107-109

Envolvimento Real com o Cliente, 29, 69, 103

EP, veja Exercício Programa

Espaço Aberto Demais, 74, 77, 78, 110

Espaço de Trabalho Informativo, 38, 48, 51, 73, 76,96

Espaço Virtual Informativo, 96

Estúdio Livre, 74, 77

Estagiário Acompanhador, 69, 95

Estagiário Aprendiz, 77, 95

Estimativas, 104

Evangelistas, 88

Excesso de Hora Extra, 98

Exercícios-Programa, 109

Experiência Prévia, 47, 95

eXPerience, 82, 89

Faça Duas Vezes, 47, 48, 55, 92

Faça Você Mesmo, 65, 73, 92

Falha, 37

Fase de Exploração, 98

Fator Caminhão, 91

FDD, veja Feature Driven Development

Feature Driven Development, 5, 7

Feedback, 18

Firewall, 110

Fluxo, 37

Fofoca, 105

Folga, 39, 98, 104
Formato Formal, 101

Frederick Taylor, 3

GinLab, 50

GNU/Linux, 51, 97

Got Root?, 51, 96

Grande Personalidade, 82, 91

Grandes Bolas de Lama, 99

Happy Hour, 102

Hibernate, 68

2, 99

Histórias, 38, 99, 104, 113

de Sucesso, 91

de bootstrap, 99

Historiótipos, 99

Homem Cordial, 86

Humanidade, 36

Humorômetro, 105

Humorômetros, 114

Imersão eXtrema, 75, 113

Implantação Diária, 41, 108

Implantação Incremental, 40, 108

Inclua Comida, 102

Integração Contínua, 27, 76

Integração Continua, 107

IRC, 112, 113

ISO 9001, 64

J2EE, 68

J2ME, 68

Java, 46, 58, 65, 68

JBoss, 68

Jogo de XP, 82, 89

Jogo do planejamento, 19

Kent Beck, 3, 11, 14, 19

Kit Multimídia, 60

Kits Multimídia, 74

Laboratório de XP, 49, 57, 69, 86, 88, 90, 95, 96, 99, 101, 102, 104, 106

Lean Software Development, 5, 7

Lição de Casa, 89

Limiar de Refatoração, 107

Lista de Discussão, 63, 103

Lista de Presença, 52, 103 
Métricas Ágeis, 103

Manifesto Ágil, 5

Mantenha o Nível, 109

Mapas Mentais, 84, 89

MapSys, 74, 77

Marcador de Reuniões, 50, 59

Martin Fowler, 4, 19

Matriz de Pareamento, 109

Melhoria, 36

Mentor, 48, 69, 91

Mentoring, 45

Metáfora, 22, 106 algoritmo genético no Mico, 59

folha de pagamento da Chrysler, 22

Meta-Treinador, 63, 67, 69, 75, 92, 97, 103

Metareciclagem, 80

Metodologia comparação com método, 9, 46 definição, 9, 10

Mico, 56, 106

MinC, veja Ministério da Cultura

Ministério da Cultura, 60, 74

Modelagem Ágil, 106

Modelo em Cascata, 46, 65, 66

Mostre o Caminho, 101

MySQL, 112

Não Sou Necessário Aqui, 106

O Chefe Refatorou o Nosso Código, 107

O Suficiente, 101

Oficinas de Conhecimentos Livres, 114

Oficinas de Reflexão, veja Retrospectivas

Oi, 72,111

Oportunidade, 37

Oracle, 112

Pápeis Secundários, 47

Padrão de Codificação, 29, 97

Padrões

de design orientado a objetos, 10

de processo, 10

definição, 10

organizacionais, 10

Paggo, 67, 92, 93, 97, 98, 101, 102, 104-106, 108-

$111,113,114$

Pague Pelo Uso, 41, 93

Panelinha, 74, 109
Papéis

primeira versão, 30

segunda versão, 41

Papéis Secundários, 49, 67, 95

Papó-Em-Pé, 105

Papó-em-Pé, 56

Papo-Em-Pé, 33, 67

Papo-em-Pé, 71, 76, 81, 114

Participe de Eventos, 71, 82, 89

Passos Pequenos, 37, 70

Passos Pequenos Demais, 100

Patrocinador Local, 71, 92

Peer-to-Peer, 60

Pequenos Passos, 100

Pequenos Sucessos, 102

Personalidades Múltiplas, 46, 48, 49, 55, 59, 60, 93

Personas, 104, 112

Planejamento Ágil, 76, 114

Plante as Sementes, 89

Podcast, 84, 89

Pontos de Cultura, 60, 114

Práticas

corolário, 40

primárias, 38

primeira versão, 12,19

segunda versão, 14

Pragmatic Programming, 5, 7

Primeiro Planejamento VIP, 64, 92, 98

Princípios

primeira versão, 11

segunda versão, 14, 36

Prisão de Pareamento, 108

Programação em pares, 25

Programação eXtrema

definição, 5, 11, 14

história, 9

segunda versão, 35

Programação Pareada, 25, 63, 76, 91, 108, 114

chapa, 26

motorista, 26

Projeto Piloto, 48, 98

Propriedade Coletiva do Código, veja Código Compartilhado

Quadro Branco, 52, 106

Quadro de Histórias, 71, 79, 104, 114, 115 
Qualidade, 37

Quarterly Cycle, veja Ciclo de Estação

Radiadores de Informação, 17, 32, 51, 71, 95-97

Redução da Equipe, 40, 111

Redundância, 37

Refatoração, 24, 107

Reflexão, 37

Regra dos 80 por 20, 17

Releases Pequenos, 22

Repositório Único, 108

Repositório Único de Código, 41

Resistência ao Meta-Treinador, 103

Responsabilidade Aceita, 104

Retroperspectiva, 111

Retroperspectivas, 115

Retrospectiva, 78, 81, 105

Retrospectivas, 34, 56, 67, 71, 101, 115

Reunião de Lavar Roupa Suja, 105

Reunião de Modelagem, 106

Rich Client Application, 61

Ritmo Sustentáve, veja Trabalho Energizado

Ron Jeffries, 32

Ruby on Rails, 99

RUP, 64

Sérgio Buarque de Holanda, 86

Script de Build, 97

Script de Build, 102

Scrum, 5, 7, 33, 104

Seja Paciente, 103

Selenium, 109

Sem as Bases, 48, 59, 62, 99

Sentar Juntos, 38, 96

SGE, veja Sistema de Gerenciamento de Editais

Simplicidade, 17

Sistema de Gerenciamento de Editais, 77

Sistema de Produção Toyota, 4

Skype, 112

Smalltalk, 10, 48, 50, 59, 64, 74

Smalltalk Server Pages, 59

Spyke, 20, 75, 99

Spykes, 103, 105

Squeak, 59

Stand-Up Meetings, veja Papo-Em-Pé

Start-Up, 67

Store, 59

SubVersion, 97
Subversion, 51

SUnit, 59

Tech Day, 112

Tecnologia da Informação, 73, 88

Tempo de Estudo, 104

Tempo Extra, 63, 103

Testes

automatizados, 24, 61, 63

de aceitação, 24, 59, 109

de unidade, 24

desenvolvimento dirigido por, 24

TI, veja Tecnologia da Informação

Tiki Brasil Sprint, 78

TikiWiki, 76, 78, 99

Time Auto-Selecionado, 66, 111

Time Completo, 38, 94

Trabalho de Conclusão de Curso, 48, 86, 88

Trabalho Energizado, 28, 47, 98, 104

Tracker Bot, 113

Tradutor, 111

Treinador, 30, 91, 92

Treinador da Semana, 111

Treinador Também Programa, 73, 101

UML, 47, 106, 110

Use Arcabouços Livres, 70

Use Clientes Reais, 47, 48, 55, 60, 93

Use Projeto Real, 98

Use Software Livre, 51, 62, 97

User Arcabouços Livres, 58

Validação Externa, 82, 91

Valor Produzido, 73

Velhos Dinossauros, 68, 95, 106, 110

VisualWave, 59

VisualWorks, 59

VRaptor, 68, 99

Wiki, 46, 51, 66, 67, 75, 96, 103, 112

William Wake, 21

$\mathrm{XP}$, veja Programação eXtrema

XPlanner, 51, 55, 62, 96

XUnit, 99

Yochai Benkler, 4 